LAIR DA SILVA LOUREIRO FILHO

\title{
A COMPETÊCIA DO MUNICÍPIO NA ZONA COSTEIRA URBANA
}

TESE DE DOUTORADO

Orientadora: Professora Titular ODETE MEDAUAR

FACULDADE DE DIREITO DA UNIVERSIDADE DE SÃO PAULO

SÃO PAULO

2014 
LAIR DA SILVA LOUREIRO FILHO

\section{A COMPETÊCIA DO MUNICÍPIO NA ZONA COSTEIRA URBANA}

Tese de Doutorado apresentada à Faculdade de Direito da Universidade de São Paulo como parte dos requisitos para obtenção do título de Doutor em Direito.

SÃO PAULO

2014 
Banca Examinadora

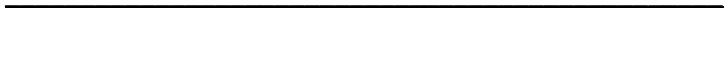

3 
Agradeço à Universidade de São Paulo pelas oportunidades oferecidas durante minha vida. Agradecimento especial à Professora Odete Medauar, exemplo a ser seguido no exercício do magistério, pela orientação recebida em todos esses anos. 


\section{S U M Á R I O}

1.1. A ocupação da zona costeira brasileira... .04

1.1.1. Conceito e delimitação da zona costeira. 04

1.1.2. Ocupação da zona costeira 11

1.2. Proteção conferida à zona costeira brasileira .14

1.2.1. Desenvolvimento sustentável da zona costeira. .15

1.2.2. Planejamento no ambiente costeiro . .24

a) plano e planejamento. .24

b) arcabouço legal.

c) Plano Nacional de Gerenciamento Costeiro. .31

1.3. Tutela da orla marítima e o terreno de marinha. . .36

1.3.1. Tratamento jurídico da orla marítima .36

1.3.2. Terreno de marinha e acrescidos 47

a) fundamentos e histórico dos institutos . .47 
2. INTERESSE LOCAL NA ZONA COSTEIRA URBANA. .66

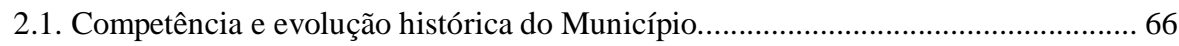

2.1.1. Competência do Município na ordem constitucional vigente......................67

2.1.2. Evolução histórica do Município no Brasil................................................72

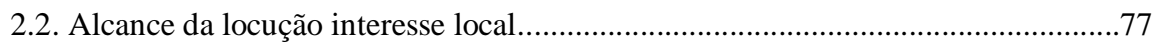

2.3. Participação do Município no Plano Nacional de Gerenciamento Costeiro................84

2.4. Gestão municipal dos terrenos de marinha e acrescidos..........................................93

2.5. O papel do Município no sistema urbanístico..........................................................110

3. O MUNICÍPIO NA PROMOÇÃO DO INTERESSE LOCAL .......................................121

3.1. Exercício do poder de polícia pelo Município..............................................................121

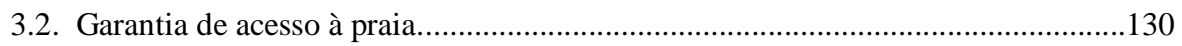

3.3. A atividade turística como novo ciclo de ocupação da região costeira

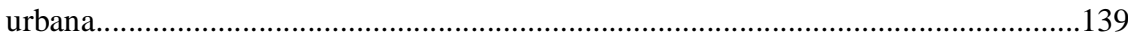

3.4. Impactos da extração de petróleo e gás......................................................................151

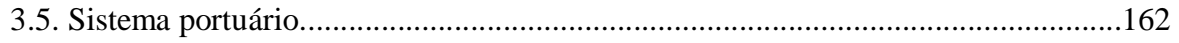

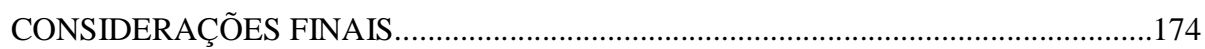

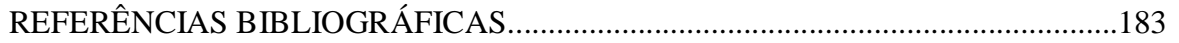


O direito administrativo encontra suas bases no altiplano das Constituições; estas se tornarão inoperantes como meras cartas de princípios sem o socorro do direito administrativo, que fará do sonho a realidade, da norma programática a efetividade da prestação administrativa, como duas faces que se completam na concretização dos ideais de justiça $e$ igualdade social (Caio Tácito) 


\section{R E S U M O}

Este trabalho visa alertar ao necessário tratamento unitário da zona costeira, com a extinção do instituto do terreno de marinha, à vista da impropriedade de seus fundamentos, da precariedade dos critérios utilizados para sua definição e dos entraves que proporciona ao desenvolvimento das regiões litorâneas, questão apenas tangenciada em escassa manifestação doutrinária, não obstante constar de dois Projetos de Emendas à Constituição.

O crescimento das demandas decorrentes das sucessivas formas de ocupação da zona costeira exige constante adaptação do plano normativo às alterações da realidade fática, mormente considerados os processos de urbanização, incremento da indústria do turismo e atividades extrativas de petróleo e gás, em vias de expansão.

$\mathrm{O}$ arcabouço jurídico a ser delineado será mais eficaz quanto mais aderente às soluções consensuais, menos intrusivas, sem prejuízo do exercício do poder de polícia quando necessário, cujos instrumentos devem ser manejados pelo Município, enquanto representante do interesse local, interesse esse que tende ao alargamento.

Propugna-se, assim, o fortalecimento do plano local, porquanto mais apto à obtenção de soluções concertadas e, portanto, dotadas de presumida eficácia, difíceis de serem obtidas no trato distante com o plano nacional. 
A peculiaridade deste trabalho consiste em abordar o tema proposto, no momento em que as consequências jurídicas da nova onda de ocupação da zona costeira brasileira, carecem de significativa reflexão doutrinária. 


\section{$R \dot{E} S \boldsymbol{U} \boldsymbol{E}$}

\section{LA COMPÉTENCE DE LA MUNICIPALITÉ DANS LA ZONE CÔTIÈRE URBAINE}

Ce travail a comme but attirer l'attention sur le nécessaire traitement unitaire de la zone côtière, avec l'extinction de l'institut du terrain de marine, en vue de l'impropriété de ses fondements, de la précarité des critères employés dans le cadre de sa définition et des obstacles qu'il entraîne au développement des régions côtières, un sujet à peine effleuré sur une rare manifestation doctrinale, en dépit de figurer sur deux Projets d'Amendements à la Constitution.

L'augmentation des demandes découlant des successives formes d'occupation de la zone côtière requiert une permanente adaptation du plan normatif aux changements de la réalité factuelle, notamment face aux processus d'urbanisation, à l'accroissement de l'industrie du tourisme et aux activités d'extraction de pétrole et de gaz, en voie d'expansion.

Le contour juridique à être délimité sera d'autant plus efficace que lorsque plus adhérant aux solutions consensuelles, moins envahissantes, sans porter atteinte à l'exercice du pouvoir de police en cas de besoin, dont les instruments doivent être gérés par la Municipalité, en tant que représentante de l'intérêt local, un intérêt à tendance à l'élargissement. 
Nous soutenons, ainsi, le renforcement du plan local, dans la mesure où il s'avère adéquat à l'obtention de solutions combinées, donc munies d'efficacité présumée, difficiles d'être obtenues dans le traitement lointain avec le plan National.

La singularité de ce travail consiste à traiter le thème proposé, au moment même où les conséquences juridiques de la nouvelle vague d'occupation de la zone côtière brésilienne demandent une importante réflexion doctrinale. 


\section{A B S TRACT}

\section{JURISDICTION OF URBAN COASTAL ZONE MUNICIPALITIES}

This paper aims at alerting to the required uniform treatment of the coastal zone, by extinguishing the institution of waterfront land, in face of inadequacies of its principles, precariousness of the criteria used for its definition, and the obstacles it poses to the development of coastal regions, an issue that is just slightly touched in doctrinaire manifestations, in spite of being mentioned in two Constitution Amendment Bills.

The growing demands, arising from the successive forms of occupation of the coastal zone, require constant adaptation of the normative plan to the objective reality, especially considering the processes of urbanization, growth of tourism industry, and oil and gas extractive activities, which are being expanded.

The legal framework to be designed shall be more effective and more adherent to consensual solutions, less intrusive, without prejudicing the exercise of police power whenever needed, whose instruments should be handled by the municipality, as a representative of local interests that tend to broaden.

Thus, it is proposed the strengthening at local level, because it is the fittest to obtain concerted solutions and, therefore, endowed with presumed efficacy, difficult to obtain far from the National plan. 
The peculiarity of this paper consists in addressing the proposed theme, at the moment in which legal consequences of the new wave of occupation of the Brazilian coastal zone lack of significant doctrinal reflection. 


\section{$R I A S S U N T O$}

\section{LA COMPETENZA DEL COMUNE DELLA ZONA COSTIERA URBANA}

Questo lavoro ha lo scopo di ammonire sul bisogno di un approccio unitario sulla zona costiera brasiliana dopo l'estinzione del terreno della Marina del Brasile, considerando l'improprietà dei suoi fondamenti, la precarietà dei criteri utilizzati per la sua definizione e gli ostacoli che questo fatto crea per lo sviluppo delle regioni costiere, problemi appena accennati nelle scarse manifestazioni giurisprudenziali, anche se vi ci sono due Proggetti di Modifiche Costituzionali,

La crescita delle esigenze che risultano delle successive forme di occupazione della zona costiera brasiliana richiede una costante adattazione del sistema normativo ai cambiamentei della realtà, soprattutto se consideriamo i processi di urbanizazzione, l'incremento del turismo e le attivitá estrattive del petroleo e gas che ora sono in espanzione.

Il sistema giuridico che va delineato sarà più efficace e più aderente alle soluzioni consensuali e meno intrusive, senza danno dell'esercizio del potere di polizia quando necessario, i cui strumenti vanno adoperati dal Comune, rappresentante dell'interesse locale, interesse che tende ad ampliarsi. 
Si propone, quindi, rendere più forte il potere locale del Comune, perché esso è il più adatto a conseguire soluzioni concertate e che hanno presunta efficacia, e che sono dificilmente raggiungibili nelle trattative com il Potere Nazionale (ou Centrale ou Federale)

La specificità di questo lavoro è l'approccio al tema proposto, in un momento in cui le conseguenze giuridiche della nova fase di occupazione della zona costiera brasiliana sono ancora prive di una riflessione giuridica importante. 


\section{LISTA DE ABREVIATURAS}

ABEMA - Associação Brasileira de Entidades de Meio Ambiente

ANTAQ - Agência Nacional de Transportes Aquaviários

CFEM - Compensação Financeira pela Exploração de Recursos Minerais

CIRM - Comissão Interministerial para os Recursos do Mar

CODESP - Companhia Docas do Estado de São Paulo

CONAMA - Conselho Nacional de Meio Ambiente

CZMA - Coastal Zone Manegement Act

DPNM - Departamento Nacional de Produção Mineral

DPMT - Domínio Público Marítimo Terrestre

FNMA - Fundo Nacional de Meio Ambiente

GI-GERCO - Grupo Interministerial de Gerenciamento Costeiro

GRPU - Gerências Regionais do Patrimônio da União

IAR - Instituto Ambiental Ratones

IBAMA - Instituto Brasileiro do Meio Ambiente e dos Recursos Naturais Renováveis

IBGE - Instituto Brasileiro de Geografia e Estatística

LOM - Lei Orgânica do Município

OEMA - Órgãos Estaduais de Meio Ambiente

PAFZC - Plano de Ação Federal para a Zona Costeira

PEGC - Plano Estadual de Gerenciamento Costeiro

PMGC - Plano Municipal de Gerenciamento Costeiro

PNGC - Plano Nacional de Gerenciamento Costeiro

PNMA - Política Nacional do Meio Ambiente

PNRM - Política Nacional dos Recursos do Mar

RQA-ZC - Relatório de Qualidade Ambiental - Zona Costeira

SIGERCO - Sistema de Informações do Gerenciamento Costeiro 
SMC - Sistema de Modelagem Costeiro

SPU - Secretaria de Patrimônio da União

SQA - Secretaria de Qualidade Ambiental

ZEE - Zoneamento Ecológico Econômico

ZEEC - Zoneamento Ecológico Econômico Costeiro

ZPP - Zona de Preservação Paisagística 


\section{A COMPETÊNCIA DO MUNICÍPIO NA ZONA COSTEIRA URBANA}

\section{INTRODUÇÃO}

Este trabalho trata da competência do Município, na defesa do interesse local na zona costeira urbana brasileira, na disciplina do uso e ocupação do solo, das atividades desenvolvidas na região e da fruição da praia enquanto bem de uso comum do povo.

A análise do tema está centrada no plano administrativo, considerada sua origem no direito constitucional e repercussões no âmbito ambiental e, em especial, urbanístico.

O trabalho tem início com o estudo da evolução legal e doutrinária conferida à zona costeira brasileira, à orla marítima e ao denominado terreno de marinha e acrescidos. Prossegue com a reflexão sobre o conceito de interesse local a partir da atuação do Município na referida região, considerada a competência que lhe é atribuída pelo regramento constitucional, com efeitos no campo administrativo, ambiental e urbanístico. Finaliza com a análise da concreção do interesse local pelo Município por intermédio do exercício do poder de polícia e de outras vias de atuação menos intrusivas, da disciplina do 
uso do solo e das atividades desenvolvidas na zona em comento, da manutenção de acesso à praia, do sistema portuário, da indústria do turismo e da extração de petróleo e gás.

Esta tese defende que o histórico da ocupação da zona costeira não foi acompanhado da correspondente atualização normativa, o que explica a manutenção do instituto do terreno de marinha, construído com base em critérios dotados de pouca cientificidade e estribado nos fundamentos de defesa nacional, instrumento condutor de política nacional de proteção ambiental e de planejamento urbano, argumentos que não mais subsistem em face da atual tecnologia de defesa, da superveniência da política urbana delineada no art. 182 da Constituição Federal, efetivada pela Lei $\mathrm{n}^{\mathrm{o}} 10.257$ de 10.07.2001, da previsão da participação do Município no Plano Nacional de Gerenciamento Costeiro, e da utilização dos recursos provenientes do Projeto Orla, especialmente pelos Municípios de pequeno porte, desprovidos de recursos e quadros.

O estudo também defende a consolidação na esfera municipal do regramento da zona costeira, compreendendo o terreno de marinha e a orla marítima, salientando-se, ainda, que este tratamento unitário não deve implicar na transferência das receitas hauridas pela União ao Município e tampouco na criação de novos tributos.

Nessa quadra, o Município emerge como instrumento chave na proteção do ambiente costeiro urbano, pois, não obstante possua competência comum aos demais para a proteção do meio ambiente, pode legislar sobre os assuntos de interesse local, desde que observados 
os princípios estabelecidos pela Constituição, pelas normas gerais federais e planos nacionais e estaduais de gerenciamento costeiro e de uso e ocupação do solo urbano.

A efetivação desse arcabouço legal se dá por meio do exercício do poder de polícia do Município, conjugado à atuação menos intrusiva e mais afeta à consensualidade, preferindo sempre a via dialógica do processo do que a mera submissão ao ato.

Acresça-se à ocupação desordenada da zona costeira e à indústria do turismo desenvolvida nas últimas décadas, o fato de que a expansão das atividades de extração e processamento de petróleo e gás na região Sudeste do país, exigirá alterações no regramento normativo do tema, à vista de um maior adensamento populacional e consequente incremento do sistema de transportes, logística e serviços, em decorrência do expressivo aumento da atividade econômica na região, com impactos ambientais e urbanísticos inevitáveis.

Desse modo, os objetivos propostos por este trabalho consistem em abordar o tema no momento em que as consequências jurídicas da nova onda de ocupação da zona costeira brasileira, carecem de significativa reflexão doutrinária; elencar os argumentos que justificam a extinção do instituto do terreno de marinha e acrescidos; e consolidar o tratamento unitário da zona costeira na esfera municipal, porquanto mais apto à obtenção de soluções concertadas e responsável pela efetivação das normas gerais no âmbito administrativo e urbanístico e pela defesa do interesse local, em regra compatível com o nacional. 


\section{TRATAMENTO JURÍDICO DA ZONA COSTEIRA NO BRASIL}

\subsection{A ocupação da zona costeira brasileira}

O processo de ocupação da zona costeira brasileira é composto por uma sucessão de ciclos, iniciado com a colonização da borda litorânea ainda no Século XVI, seguido do desenvolvimento da indústria do turismo em meados do Século XX, culminando com a instalação da atividade extrativista de petróleo e gás.

Essa diversidade de atividades desenvolvidas na região, sem adequado planejamento ambiental e urbanístico, somada a um regramento jurídico confuso, obsoleto e em descompasso com as demandas econômicas e sociais que ora se apresentam, constituem entraves ao desenvolvimento sustentável da zona costeira, conforme será visto no curso deste trabalho.

\subsubsection{Conceito e delimitação da zona costeira}

Pela definição do parágrafo único do art. $2^{\circ}$ da Lei $n^{\circ} 7.661$, de $16.05 .1988^{1}$, considera-se zona costeira o espaço geográfico de interação do ar, do mar e da terra, incluindo seus

1 Projeto 216-A/87, portanto antes mesmo da promulgação da Carta de 88 que a define como patrimônio nacional no art. $225, \S 4 \stackrel{\circ}{\circ}$. 
recursos renováveis ou não, abrangendo uma faixa marítima e outra terrestre, que serão definidas pelo Plano.

A região abriga um conjunto complexo de ecossistemas de alta relevância ambiental, cuja diversidade é marcada pela transição de ambientes terrestres e marinhos, com interações que lhe conferem um caráter de fragilidade e que requerem, por isso, atenção especial de todos em geral, e do poder público em especial, o que justifica a sua inserção no art. 225 da Constituição Federal como área de patrimônio nacional. ${ }^{2}$

A zona costeira brasileira, com 7.400 km de extensão (sem considerar baías e reentrâncias, o que totaliza $8.500 \mathrm{~km})$, compreende três grandes sistemas: o oceânico, o atmosférico e o continental, variando, na largura, de 70 a $480 \mathrm{~km}$. Nela vive um quarto da população, aproximadamente 36,5 milhões de pessoas, residentes em cerca de 500 municípios, com densidade populacional de $87 \mathrm{~h} / \mathrm{km}^{2}$, cinco vezes a média nacional. ${ }^{3}$

2 Art. 225, § 4ํA Floresta Amazônica brasileira, a Mata Atlântica, a Serra do Mar, o Pantanal Mato Grossense e a Zona Costeira são patrimônio Nacional, e a sua utilização far-se-á na forma da lei, dentro de condições que assegurem a preservação do meio ambiente, inclusive quanto ao uso dos recursos naturais.

3 Relação dos municípios abrangidos pela faixa terrestre da zona costeira: Amapá (Oiapoque, Calçoene, Amapá, Itaubal, Macapá, Santana e Cutias), Pará (Afiuá, Chaves, Soure, Salvaterra, Cachoeira do Arari, Barcarena, Belém, Ananindeuá, Santo Antonio do Tauá, Colares, Benevides, Vigia, São Caetano de Odivelas, Curuça, Marapanim, Magalhães Barata, Maracanã, Salinópolis, São João de Pirabás, Primavera, Bragança, Augusto Corrêa, Vizeu, Santa Bárbara do Pará e Quatipuru), Maranhão (Carutapera, Luís Domingues, Godofredo Viana, Cândido Mendes, Tiriaçu, Bacuri, Cururupu, Cedral, Guimarães, Bequimão, Alcântara, Cajapió, São João Batista, Anajatuba, Santa Rita, Rosário, São Luís, Raposa, Paço do Lumiar, São José de Ribamar, Axixá, Icatu, Humberto de Campos, Primeira Cruz, Barreirinhas, Tutóia e Araioses), Piauí Cajueiro da Praia, Ilha Grande, Parnaíba e Luiz Correia), Ceará (Chaval, Barroquinha, Camocim, Cruz, Jiboca de Jericoacoara, Acaraú, Itarema, Amontada, Itapipoca, Trairi, Paraipaba, Paracuru, São Gonçalo de Amarante, Caucáia, Fortaleza, Maracanaú, Maranguape, Horizonte, Pacajus, Itaitinga, Guaiúba, Pacatuba, Eusébio, Aquiraz, Pindoretena, Cascavel, Beberibe, Aracati e Icapuí), Rio Grande do Norte (Grossos, Tibau, Areia Branca, Mossoró, Carnaubais, Macau, Guamaré, Galinhos, São Bento do Norte, Pedra Grande, Touros, Maxaranguape, Rio do Fogo, CearáMirim, Extremoz, Natal, Parnamirim, Nísia, Floresta, Senador Georgino Avelino, Goianinha, Arês, Tibau 
Com o predomínio de uma estreita franja de litoral, a costa brasileira apresenta grandes estoques de manguezais e estuários, formando extensa planície lodosa ao Norte; dunas, rios e recifes de franja ao Nordeste; recifes de franja, parceis e deltas ao Leste; baías e lagunas no Sudeste e lagunas ao Sul.

do Sul, Vila Flôr, Canguaretama, Baia e Formosa), Paraíba (Mataracá, Baía da Traição, Rio Tinto, Lucena, Cabedelo, João Pessoa, Bayeux, Santa Rita, Condé, Pitimbu, Caaporã e Alhandra), Pernambuco (Goiana, Itapissuma, Itamaracá, Igarassu, Abreu e Lima, Paulista, Olinda, Recife Camaragibe, São Lourenço da Mata, Jaboatão dos Guararapes, Moreno, Cabo, Ipojuca, Sirinhaém, Rio Formoso, Tamandaré, Barreiros e São José da Coroa Grande), Alagoas (Maragogi, Japaratinga, Porto de Pedras, São Miguel dos Milagres, Passo de Camaragibe, Barra de Santo Antônio, Maceió, Pilar Satuba, Paripueira, Santa Luzia do Norte, Coqueiro Seco, Marechal Deodoro, Barra de São Miguel, Roteiro, São Miguel dos Campos, Coruripe, Piaçabuçu, Felix Deserto e Penteado, Sergipe (Brejo Grande, Pacatuba, Indiaroba, Pirambu, Santa Luzia do Itanhy, Barra dos Coqueiros, Laranjeira, Santo Amaro das Brotas, Riachuelo, Aracaju, Maruim, Nossa Senhora do Socorro, Rosário do Caeté, São Cristóvão, Itaporanga D'Ajuda, Estância, Ilhas das Flores e Neópolis), Bahia (Jandaíra, Conde, Esplanada, Cardeal da Silva, São Félix, Mata de São João, Itanagra, Camaçari, Dias D’Ávila, Lauro de Freitas, Salvador, Simões Filho, Aratuipe, Candeias, Taperoá, São Francisco do Conde, Madre de Deus, Santo Amaro, Cachoeira, Saubara, Maragigipe, Salinas da Margarida, Itaparica, Vera Cruz, Jaguaripe, Valença, Cairú, Nilo Peçanha, Ituberá, Igrapiúna, Camamu, Maraú, Itacaré, Uruçuca, Ilhéus, Una, Canavieira, Belmonte, Santa Cruz de Cabrália, Porto Seguro, Prado, Alcobaça, Caravelas, Nova Viçosa e Mucuri), Espírito Santo (Conceição da Barra, São Mateus, Jaguaré, Linhares, Sooretama, Aracruz, Fundão, Serra, Vitória, Cariacica, Vila Velha, Viana, Guarapari, Anchieta, Piúma, Presidente Kennedy, Itapemirim e Marataizes), Rio de Janeiro (São João da Barra, São Francisco de Itabapoana, Campos dos Goytacazes, Quissamã, Carapebus, Macaé, Casimiro de Abreu, Rio das Ostras, Armação de Búzios, Cabo Frio, São Pedro d'Aldeia, Arraial do Cabo, Araruama, Saquarema, Maricá, Itaboraí, Niterói, São Gonçalo, Magé, Guapimirim, Duque de Caxias, Rio de Janeiro, São João do Meriti, Nilópolis, Nova Iguaçu, Queimados, Japeri, Belford Roxo, Itaguaí, Seropédica, Mangaratiba, Angra dos Reis e Parati), São Paulo (Ubatuba, Caraguatatuba, São Sebastião, Ilha Bela, Bertioga, Guarujá, Cubatão, São Vicente, Santos, Praia Grande, Mongaguá, Itanhaém, Peruíbe, Iguape, Cananéia e llha Comprida), Paraná (Quaraqueçaba, Antonina, Morretes, Paranaguá, Pontal do Paraná, Matinhos e Guaratuba), Santa Catarina (Itapoá, São Francisco do Sul, Joinville, Araquari, Balneário Barra do Sol, Barra Velha, Imaruí, Piçarras, Capivari de Baixo, Penha, Navegantes, Itajaí, Balneário Camboriú, Camboriú, Itapema, Porto Belo, Tijucas, Governador Celso Ramos, Biguaçu, Florianópolis, São José, Palhoça, Paulo Lopes, Garopaba, Imbituba, Laguna, Jaguaruna, Içara, Araranguá, Sombrio, São João do Sul, Bombinhas, Guaruva, Passo de Torres, Tubarão, Criciúma, Sangão e Santa Rosa do Sul), Rio Grande do Sul (Torres, Arroio do Sal, Três Cachoeiras, Três Forquilhas, Maquiné, Capão da Canoa, Terra da Areia, Xangrilá, Osório, Imbé, Tramandaí, Cidreira, Palmares do Sul, Viamão, Mostardas, Barra do Ribeiro, Tapes, Tavares, Camaquã, Atambé, São José do Norte, São Lourenço do Sul, Rio Grande, Pelotas, Arroio Grande, Jaguarão e Santa Vitória do Palmar). 
Cabe, aqui, a indagação sobre a exata abrangência da zona costeira, para que se delineie a eficácia espacial (dominial) e material (atividade) das normas que lhe são próprias, ressaltando desde logo não se tratar de uma área estanque e homogênea.

MARIANA ALMEIDA PASSOS DE FREITAS salienta a peculiaridade do sistema litorâneo: “O ecossistema litorâneo é todo especial. Nele se encontra uma variedade de habitats e ecossistemas, como restingas, costões, manguezais, ilhas, dunas, praias arenosas, dentre outros, nos quais estão abrigadas inúmeras espécies da flora e da fauna brasileiras". ${ }^{4}$

A área de abrangência do Plano Nacional de Gerenciamento Costeiro compreende as faixas marítima e terrestre. Pela primeira, entende-se a faixa que se estende mar afora distando 12 milhas marítimas das linhas de base estabelecidas de acordo com a Convenção das Nações Unidas sobre o Direito do Mar de 1982, realizada em Montego Bay na Jamaica, compreendendo a totalidade do Mar Territorial. A segunda aponta a faixa do continente formada pelos municípios que sofrem influência direta dos fenômenos ocorrentes na zona costeira: a) os municípios defrontantes com o mar, assim considerados em listagem dessa classe, estabelecida pelo Instituto Brasileiro de Geografia e Estatística - IBGE; b) os municípios não defrontantes com o mar que se localizem nas regiões metropolitanas litorâneas; c) os municípios contíguos às grandes cidades e às capitais estaduais litorâneas, que apresentem processo de conurbação; d) os municípios próximos ao litoral, até $50 \mathrm{~km}$ da linha de costa, que aloquem, em seu território, atividades ou infraestruturas de grande impacto ambiental sobre a zona costeira e ecossistemas costeiros de alta relevância; e) os municípios

4 Zona costeira e meio ambiente, Curitiba, Juruá, 2005, p. 27. 
estuarinos-lagunares, mesmo que não diretamente defrontantes com o mar, dada a relevância desses ambientes para a dinâmica marítimo-litorânea; f) os municípios que, mesmo não defrontantes com o mar, tenham todos seus limites estabelecidos com os municípios referidos nas alíneas anteriores. ${ }^{5}$

JACQUELINE MORAND-DEVILLER lembra que no direito francês não há definição jurídica de litoral e a relação dos municípios litorâneos é fixada por decreto em Conselho de Estado, ou seja, um decreto submetido pelo Governo à apreciação do Conselho de Estado, considerando três categorias: aqueles localizados à beira mar, os situados em estuários e deltas e, por fim, os municípios próximos desses que sofrem efeitos econômicos e ecológicos do litoral. ${ }^{6}$

De acordo com FERNANDO QUADROS DA SILVA: "Não é suficiente gerir o mar sem considerar as atividades desenvolvidas nas áreas próximas. As atividades desenvolvidas no território costeiro têm reflexos diretos no mar territorial". ${ }^{7}$

O fato de ser considerado patrimônio nacional, contudo, não justifica atribuir titularidade exclusiva à União.

5 PNGC II, item 3 da Resolução no 05, de 03.12.1997.

6 Droit de l'urbanisme. 3 ed., Dalloz, 1996, p. 29.

7. Tutela das águas do mar, p. 187, in Vladimir Passos de Freitas (Coord.), Águas, aspectos jurídicos e ambientais, 3 ed., Curitiba, Juruá, 2007. 
O Plano Nacional de Gerenciamento Costeiro, aprovado pela Resolução n. 01, de 21.11.1990 ${ }^{8}$, optou por delegar aos Planos Estaduais a definição dos limites físicos do que venha a ser o ecossistema denominado de zona costeira ${ }^{9}$.

A heterogeneidade da costa brasileira, seja no tocante às paisagens e aspectos naturais, seja em relação à forma de sua ocupação, bem como sua extensão permite, ou melhor, exige a integração dos níveis locais e regionais com o nacional para que o Plano conheça razoável eficácia.

Dessa forma, uma gama de critérios deve ser adotada na definição dos limites da zona costeira, abandonado aquele pautado apenas nas distâncias fixas. É o que dispõe o item 3.2 da Resolução nº 01, de 21.11.1990, que aprovou o Plano Nacional de Gerenciamento Costeiro: a) não fragmentação da unidade natural dos ecossistemas costeiros; b) para a linha externa da faixa terrestre, a linha de cristas da configuração topográfica do litoral ou, no caso de planícies costeiras muito extensas, o ponto até onde se faz sentir a influência do mar; c) para o limite externo da faixa marítima, o espaço submerso até onde ocorram movimentos (ondas, correntes e marés), que possam ocasionar processos naturais (sedimentação ou erosão) capazes de afetar a natureza constitutiva da costa; d) considerar áreas marcadas por intensa atividade econômica e sua área de influência.

\footnotetext{
8 Cf. infra 1.2.2.
}

${ }^{9}$ As Constituições estaduais apresentam farta exemplificação. A Constituição Paulista (art. 196) menciona a proteção ao Complexo Estuarino Lagunar entre Iguape e Cananéia, bem como aos manguezais e áreas estuarinas (art. 197, I e IV); a Baiana (art. 215, III), a Maranhense (art. 241, IV, d), e a Paraibana (art. 227, p.u.) os recifes; a Pernambucana (art. 205) dos "arrecifes"; a Paraibana (art. 227, p.u., IX) e a Fluminense (art. 265, II) as praias, incluindo esta última os costões rochosos; entre outras. Em São Paulo, a Lei oㅜ 10.019, de 03.07.1998, estabelece as bases do zoneamento costeiro no Estado. 
Diante da impossibilidade técnica ou ausência de manifestação legislativa estadual para a definição de tais parâmetros, deverão ser adotados os seguintes critérios gerais: a) para a faixa marítima: 5 milhas marítimas $(11,1 \mathrm{~km})$ sobre uma perpendicular, contadas a partir da Linha da Costa; b) para a faixa terrestre: $20 \mathrm{~km}$ sobre uma perpendicular, contados a partir da Linha da Costa.

Há que se considerar, portanto, que nas políticas de ordenamento territorial, "não se deve mais conceber a costa como uma rigorosa linha de separação, mas como um elemento da terra, em que o interesse humano é determinado pela proximidade do mar; nem o mar deve ser concebido como um mundo diferente e ilimitado, mas como uma realidade próxima que se presta, pelo seu fundo e pelo seu subsolo, a uma variada utilização mais diferenciada que no passado. ${ }^{10}$

Para os fins desta tese, a análise se restringe à zona costeira urbana e à contraposição de competências federativas na disciplina do uso e ocupação do solo e das atividades desenvolvidas na região, cuja delimitação deve resultar da conjugação do critério territorial com aspectos relevantes da vida social e econômica.

\footnotetext{
${ }^{10}$ Carta de Torremolinos (Espanha, 1983), citada por Paulo Affonso Leme Machado, Direito ambiental brasileiro, 21 ed., São Paulo, Malheiros, 2013, p. 455.
} 


\subsubsection{Ocupação da zona costeira}

No Brasil, a zona costeira é a faixa de urbanização mais antiga do país, pois, dos dezoito primeiros núcleos fundados pelos portugueses, apenas São Paulo não se encontrava à beiramar.

Nessa faixa estão significativas referências de nossa identidade nacional, bem como as áreas de interesse turístico, de recreação e lazer, atividades que proporcionaram uma segunda fase na sua ocupação, agora às voltas com as descobertas de expressivas jazidas de petróleo e gás, que delinearão nova moldura à região.

A ocupação do interior do território brasileiro deu-se pelo deslocamento de contingentes populacionais para o sertão, seja pela busca de riquezas minerais, pelos ciclos econômicos da borracha e do gado, ou por estratégias geopolíticas para o planalto central, com a construção das cidades de Brasília e Goiânia.

ANTONIO CARLOS MORAES ${ }^{11}$ observa que a colonização do Brasil começou pelo mar, com os primeiros assentamentos localizados na costa. A partir daí iniciaram-se os fluxos de colonização do interior, através de um padrão denominado bacia de drenagem, reproduzindo o padrão um desenho na estruturação da rede de circulação, no qual todos os caminhos demandavam um eixo principal, e este finalizava seu curso num porto marítimo. Após esse 11 Contribuição para a gestão da zona costeira do Brasil, São Paulo, Annablume-HUCITEC/EDUSP, 2007, p. 31. 
período seguiu-se a industrialização e a consolidação urbano-industrial concentrada em áreas portuárias, ocasionando ao final a ocupação dos vazios existentes com a indústria do turismo com o fenômeno das segundas residências.

As atividades econômicas costeiras são responsáveis pela parcela majoritária do PIB nacional, principalmente devido à existência de portos nos quais é realizada grande parte da atividade econômica exportadora brasileira, decorrendo dessa conjuntura natural, econômica e social, três grupos de impactos ambientais: o extrativismo animal e vegetal; a infraestrutura urbana, portuária, de turismo, transporte e lazer; e a agricultura, pastagens e silvicultura localizadas.

O bem estar e, em alguns casos, a própria sobrevivência das populações litorâneas dependem da saúde e das condições dos sistemas costeiros, o que exige a definição de instrumentos de efetivo combate à poluição, coleta de esgotos e de lixo, bem como normas relativas ao gabarito das construções e atividades desenvolvidas na região. ${ }^{12}$

Todavia, até o momento o Estado brasileiro foi incapaz de promover o desenvolvimento sustentável da região costeira e de atender à demanda por serviços públicos básicos, gerando um quadro de carências estruturais e consequente exclusão social, refletido na ocupação irregular de áreas, na favelização e no aumento da criminalidade.

12 Sobre os efeitos da atividade industrial na zona costeira, conferir Claudio A. Gonçalves Egler, Os impactos da política industrial sobre a zona costeira. Brasília: Ministério do Meio Ambiente, 1997. 
CONSTANZA DE CARVALHO BELCHIOR ${ }^{13}$ observa que um dos fatores mais relevantes, causador de uma aceleração da degradação dos ecossistemas costeiros está ligado à aglomeração de uma população mundial em crescimento nas zonas costeiras, cuja superfície é bem menor do que as áreas continentais interiores ${ }^{14}$ : "Em 1990 tínhamos 1.96 bilhões de pessoas vivendo a menos de $100 \mathrm{~km}$ da linha de costa, enquanto que em 1995 esse número já tinha ascendido a 2.14 bilhões de pessoas. Ou seja, em 1995, 39\% da população mundial ocupava uma zona que representa apenas $20 \%$ da superfície terrestre, tendência de crescimento mantida".

FILOMENA MARTINS e HENRIQUE ALBUQUERQUE ${ }^{15}$ salientam, como um dos problemas mais relevantes do litoral português, a excessiva concentração populacional e a erosão. "Um dos problemas mais relevantes do litoral é a excessiva concentração populacional que exerce uma forte pressão sobre a zona costeira. Esta excessiva concentração populacional gera problemas sobre os recursos naturais, nomeadamente a degradação da paisagem, a sobre-exploração dos recursos, a poluição do ambiente (ar, água e sedimentos), a

13 Gestão costeira integrada - Estudo de caso do Projeto ECOMANAGE na região estuarina de Santos - São Vicente - Dissertação em Ciência Ambiental, Instituto Oceanográfico USP, 2008, p. 1314.

14 De acordo com a Agenda 21, documento que coroou a ECO/92 - Conferência das Nações Unidas sobre Meio Ambiente e Desenvolvimento, integrado por um complexo de compromissos jurídico-político destinado a definir uma transformação nos padrões de desenvolvimento da humanidade, a maior parte da população mundial está concentrada em zonas costeiras, havendo uma tendência permanente ao aumento da concentração demográfica nessas regiões: Cap. 17, item 3. A área costeira contém habitats diversos e produtivos, importantes para os estabelecimentos humanos, para 0 desenvolvimento e para a subsistência das populações locais. Mais de metade da população mundial vive num raio de 60 quilômetros do litoral e esse total pode elevar-se a 75 por cento até o ano 2000. Muitos dentre os pobres do mundo vivem aglomerados nas zonas costeiras. Os recursos costeiros são vitais para muitas comunidades locais e populações indígenas. A zona econômica exclusiva também é uma importante área marinha, onde os Estados gerenciam o desenvolvimento e a conservação dos recursos naturais em benefício de suas populações. Em se tratando de pequenos Estados ou países insulares, essas são as regiões que melhor se prestam às atividades ligadas ao desenvolvimento.

15 Políticas de planejamento, ordenamento e gestão costeira: contributo para uma discussão metodológica. Tese de Doutorado. Universidade de Aveiro, 1998, p. 336. 
alteração do uso do solo trazendo como resultado a impermeabilização para a construção de infraestruturas, com implicações em nível das escorrências e drenagens naturais.

Outro grande problema sentido na zona costeira é a erosão, verificando-se nos últimos anos um acentuado recuo da linha da costa em vários troços costeiros portugueses. Esta erosão deve-se à excessiva concentração de construções no litoral, às pressões das atividades dos visitantes, nomeadamente na época alta, e ainda à excessiva exploração de interesses econômicos nos rios, estuários e litoral e dragagens portuárias, que diminuem as areias que deveriam alimentar o litoral".

Desta forma, o aumento da concentração populacional da zona costeira provoca efeitos de toda ordem na região, como a degradação ambiental, o crescimento urbano desordenado e a alteração de sua geografia física.

\subsection{Proteção conferida à zona costeira brasileira}

Neste tópico será visto que, por força de disposição constitucional e contínuo regramento normativo, com destaque para o Plano Nacional de Gerenciamento Costeiro - PNGC II, a zona costeira brasileira constitui patrimônio nacional, devendo sua exploração ocorrer de forma sustentável, o que traz à tona a problemática da resolução da colidência entre princípios. 


\subsubsection{Desenvolvimento sustentável da zona costeira}

A região possui características naturais e recursos ambientais, fundamentais para a manutenção do equilíbrio ecológico necessário à sadia qualidade de vida e ao desenvolvimento econômico e social do Brasil, que deverá se dar de forma sustentável.

Para ANA MARIA NUSDEO, o termo desenvolvimento sustentável representa, em nosso contexto, "a exploração adequada do meio ambiente, a menos agressiva, a que é feita de forma que não comprometa a manutenção da existência da espécie natural, tanto no plano presente quanto para o futuro. Essa ideia surgiu em 1987 com o relatório da Comissão Mundial sobre Meio Ambiente da ONU (Relatório Brundtland ${ }^{16}$, publicado em 1987 sob o título Nosso futuro comum), ganhando fortalecimento com a ECO/92". ${ }^{17}$

Prossegue a autora, em outro estudo, asseverando que "o modelo de sustentabilidade gira em torno de um consumidor socialmente sustentável (consome com moderação, selecionando empresas comprometidas com o meio ambiente natural). É a verdadeira harmonização dos interesses dos consumidores com a necessidade de aumento do bem estar geral da sociedade,

16 Gro Harlem Brundtland era primeira-ministra da Noruega por ocasião da elaboração do relatório, texto preparatório à ECO 92.

17 Desenvolvimento sustentável no direito e o Protocolo de Quioto. in Revista de Direito Ambiental, no 37, ano 10, jan.-mar. de 2005, São Paulo, RT, p. 144-159. 
através do aumento da produtividade e da inovação, balizada pela alocação eficiente dos recursos". 18

Destarte, o desenvolvimento é sustentável quando satisfaz as necessidades presentes sem comprometer a habilidade das futuras gerações em satisfazer as suas próprias, compatibilizando a expansão e a eficiência da atividade econômica com a sustentabilidade econômica e ecológica.

CRISTIANE DERANI aponta às dificuldades de se compatibilizar a limitação dos recursos naturais com o ilimitado crescimento econômico: "Os criadores dessa expressão partem da constatação de que os recursos naturais são esgotáveis. Por outro lado, apoiam-se no postulado de que o crescimento constante da economia é necessário para expandir-se o bem estar pelo mundo, ajustando uma correlação de valores em que o máximo econômico reflita igualmente um máximo ecológico. Conclui que a tentativa de conciliar a limitação dos recursos naturais com o ilimitado crescimento econômico, é condicionada à consecução do desenvolvimento sustentável e a mudanças no estado da técnica e na organização social”. ${ }^{19}$

A noção de desenvolvimento sustentável se apresenta em cinco dimensões: a) social: devido à disrupção social que paira de forma ameaçadora sobre muitos lugares problemáticos de nosso planeta; b) ambiental: que leva em conta o meio ambiente como sistema de sustentação da vida, provedor de recursos e recipiente para a disposição de resíduos; c) territorial:

18 Defesa da concorrência e globalização econômica: o controle da concentração de empresas, São Paulo, Malheiros, 2002, p. 249. Ver também da mesma autora, O uso de instrumentos econômicos no direito ambiental. Revista da Faculdade de Direito da Universidade de São Paulo, 2006, p. 357-378.

19 Direito ambiental econômico, 3 ed., São Paulo, Saraiva, 2008, p. 110-112. 
relacionado à distribuição espacial dos recursos das populações e atividades; d) econômico: sendo a viabilidade econômica a conditio sine qua non para que as coisas aconteçam; e) político: a governança democrática é um valor fundador e um instrumento necessário para fazer as coisas acontecerem. ${ }^{20}$

Para assegurar o desenvolvimento sustentável da zona costeira, estabelecendo uma série de limitações ao seu uso, JUAN JESÚS TRAPERO observa que uma exploração racional dos recursos costeiros e o uso equilibrado do espaço litorâneo exigem que as decisões tomadas sobre o litoral levem em conta as condicionantes ambientais, sopesados os direitos e interesses dos usuários e proprietários com predomínio do interesse geral, especialmente em longo prazo, assegurada a transparência e a publicidade, a fim de se evitar privilégios de determinados grupos ou pessoas. ${ }^{21}$

JOHN. R. CLARK ${ }^{22}$ também chama atenção ao uso sustentável dos recursos da zona costeira, como forma de preservar a qualidade de vida das futuras gerações, ponderando que os objetivos do desenvolvimento econômico devem ser formulados de modo a satisfazer as necessidades básicas e assegurar a qualidade de vida da população costeira sem comprometer a capacidade produtiva e a utilização eficiente dos recursos naturais a longo prazo.

20 Conferir o trabalho de Ignacy Sachs, Desenvolvimento: includente, sustentável, sustentado, Rio de Janeiro, Garamond, 2004, p. 15 e ss.

21 Aspectos urbanísticos de la protección del territorio litoral, Revista de Derecho Urbanistico, v. 117, mar.-abr. 1990, p.55.

22 Coastal zone management, New York, Lewis Publisher, 1996, p. 436-437. 
Em outro plano, JACQUELINE MORAND-DEVILER ${ }^{23}$ assevera em interessante estudo, que a felicidade do indivíduo está inseparável de seu bem estar e do direito de todos a um meio ambiente sadio: "a busca dos valores-penas poderia juntar-se aos da avaliação do risco. Admitindo-se que o risco zero não exista, a maximização da felicidade repousaria na determinação do risco aceitável, pois todo risco não aceitável levaria à 'pena' e à dor, diante das quais os indivíduos não são iguais. O 'bom governo do risco’ exige prudência, a também chamada precaução, a fim de levar em consideração as situações, mesmo aleatórias, e fazer as escolhas políticas suscetíveis de conduzir ao máximo de bem estar, através da redução da gravidade do mal estar".

Nessa linha, o conceito de desenvolvimento passa de uma visão tradicional, centrada na percepção das variáveis econômicas, para uma visão holística, mais abrangente, considerando diversos aspectos relativos à qualidade de vida e impactos regionais.

Entretanto, ao cotejo dos avanços econômicos e tecnológicos obtidos pela humanidade com a deterioração das condições de vida no planeta, alguns autores prenunciam panorama demasiadamente sombrio.

23 O justo e o útil em Direito Ambiental, p. 70-79. Le juste et l'utile em droit de l'environnement. Pour um droit commun de l'environnement - mélanges em honneur de Michel Prieur, p. 323-331, Paris: Dalloz. Tradução de Raquel Thais Runsche, Cristina Lemos Lopes e Solange Teles da Silva. In Solange Teles Silva; Odete Medauar; Claudia Lima Marques. O novo direito administrativo, ambiental e urbanístico - Estudos em homenagem a Jacqueline Morand-Deviler, São Paulo, Revista dos Tribunais, 2010. 
É a posição de BERNARD DROBENKO 24: “A humanidade tornou-se desrespeitosa de si mesma, revelando o homem na plenitude de sua mediocridade. Mas a Humanidade é também desrespeitosa de suas próprias condições de vida e de seus ecossistemas. As evoluções ocorridas levaram a uma situação intolerável, indigna da inteligência humana - isso, ao mesmo tempo em que se produz abundante riqueza (...). Ao mesmo tempo - e pela primeira vez na breve História da Humanidade, os seres humanos são capazes de destruir de maneira irreversível certos ecossistemas, certas espécies ou espaços, mas também as condições globais de vida sobre o planeta".

A vista desse paradoxo, a Constituição elevou à condição de princípio de alta relevância a proteção ambiental, como interesse de titularidade de toda a humanidade, a despeito da nacionalidade ou da condição de estar vivo, portanto transnacional, transindividual e intergeracional.

Dessa forma, o direito de acesso e fruição de bem público, ao colidir com o direito ao ambiente ecologicamente equilibrado, traz a ideia de resolução dos conflitos entre princípios pelo critério do peso.

24 A caminho de um fundamento para o direto ambiental. Tradução de Simone Wolff. In Sandra Akemi Shimada Kishi; Solange Teles da Silva; Inês Virgínia Prado Soares. Desafios do direito ambiental no século XXI - Estudos em homenagem a Paulo Affonso Leme Machado, São Paulo, Malheiros, 2005, p. 59-84. 
A respeito da colidência entre princípios e regras, vale a lição de VIRGÍLIO AFONSO DA

$\mathrm{SILVA}^{25}$, para quem princípios se diferenciam de regras, pois não exigem a realização total, permitindo conformação. No caso dos princípios não se pode falar em realização sempre total daquilo que a norma exige. Ao contrário: em geral essa realização é apenas parcial. Isso, porque no caso dos princípios há uma diferença entre aquilo que é garantido (ou imposto) prima facie e aquilo que é garantido (ou imposto) definitivamente'.

De acordo com ROBERT ALEXY26: “O ponto decisivo da distinção entre regras e princípios é que 'princípios' são normas que ordenam que algo seja realizado na maior medida possível dentro das possibilidades jurídicas e fáticas existentes. Princípios são, por conseguinte, ‘mandamentos de otimização', que são caracterizados por poderem ser satisfeitos em graus variados e pelo fato de que a medida devida de sua satisfação não depende somente das possibilidades fáticas, mas também das possibilidades jurídicas. O âmbito das possibilidades jurídicas é determinado pelos princípios e regras colidentes.

E mesmo a preferência deve ser ponderada, isso porque, mesmo depois de determinado qual princípio deve prevalecer, das medidas capazes de realizá-lo, deverá ser escolhida aquela que cause menor prejuízo aos demais princípios não escolhidos.

25 Direitos fundamentais - conteúdo essencial, restrição e eficácia, 2 ed., São Paulo, Malheiros, 2011, p. $45-46$.

26 Teoria dos direitos fundamentais, (Trad. Virgílio Afonso da Silva), São Paulo, Malheiros, 2011, p. 9091. 
Já as regras são normas que são sempre ou satisfeitas ou não satisfeitas. Se uma regra vale, então deve se fazer exatamente aquilo que ela exige: nem mais, nem menos. Regras contêm, portanto, 'determinações' no âmbito daquilo que é fática e juridicamente possível. Isso significa que a distinção entre regras e princípios é uma distinção qualitativa, e não uma distinção de grau. Toda norma é ou uma regra ou um princípio”.

VIRGÍLIO AFONSO DA SILVA observa que, quando um princípio entra em colisão com uma regra, deve haver um sopesamento, mas esse sopesamento não ocorre entre o princípio e a regra, já que regras não são sopesáveis, Ele deve ocorrer entre o princípio em colisão e o principio no qual a regra se baseia. ${ }^{27}$

Ao aludir à tormentosa questão da colidência entre regras e princípios, no caso específico do acesso à praia, FLORIANO DE AZEVEDO MARQUES NETO ${ }^{28}$ lembra, também com esteio na lição de ALEXY, que "a densidade que faz um princípio jurídico prevalecer em relação a outro não pode ser tomada como definitiva, restando eminentemente conjuntural (...). O peso diferencial da proteção ambiental é infinitamente mais denso que o uso irrestrito de bem público travestido na impossibilidade de limitar o acesso dos eventuais banhistas às áreas praianas".

27 Direitos fundamentais - conteúdo essencial, restrições e eficácia, p. 58-59.

28 A possibilidade de restrição de acesso a bens públicos de uso comum por questões ambientais e urbanísticas, Boletim de Direito Administrativo, 6, São Paulo, NDJ, jun. 2007, p. 668-669. Ver também do mesmo autor $\mathrm{O}$ conflito entre princípios constitucionais: breves pautas para sua solução, Cadernos de Direito Constitucional e Ciência Política, São Paulo, Revista dos Tribunais/Instituto Brasileiro de Direito Constitucional, vol. 10, jan.-mar. 1995, p. 40-45. 
No mesmo estudo, prossegue o autor salientando a preponderância da preservação ambiental, vislumbrando mecanismos que viabilizam tal harmonização: a) restrição ao tráfego e ao acesso imposta pelo poder público no exercício do seu poder de polícia; b) a outorga de uso privativo de bem público mediante condição de preservação ambiental.

Assim, o princípio da função social da propriedade, previsto no rol dos direitos e garantias fundamentais e na ordem econômica, longe de constituir antinomia ao direito de propriedade, integra a sua estrutura ao lhe fornecer os instrumentos necessários para assegurar o direito ao desenvolvimento sustentável como direito fundamental. $^{29}$

Trata-se de síntese da dialética estabelecida entre os princípios do desenvolvimento econômico e o direito ao meio ambiente equilibrado.

Nesse sentido, o princípio da função social da propriedade define os contornos da propriedade (pública e privada) e direciona as políticas públicas. É o que aponta o escólio de GUILHERME JOSÉ PURVIN DE FIGUEIREDO ${ }^{30}$, para quem: "Ele constitui a via para a implementação dos valores arrolados no caput do art. 225 da CF e, sem ele, tais valores tornar-se-iam uma abstração. Por esse princípio, pretende-se a adequação do exercício do

29 Conferir nessa linha Antonio Herman Benjamin (Org.) Direitos humanos e meio ambiente. São Paulo: Imprensa Oficial do Estado, 2006; Antonio Augusto Cançado Trindade. Direitos humanos e meio ambiente: paralelo dos sistemas de proteção ambiental. Porto Alegre: Fabris, 1993; Meio ambiente e desenvolvimento: formulação e implementação do direito ao desenvolvimento como um direito humano. Boletim da Sociedade Brasileira de Direito Internacional, ano XLV, no 81/83, jul.-nov. 1992, p. 49-76; Tiago Fensterseifer. Direitos fundamentais e proteção do ambiente. A dimensão ecológica da dignidade humana no marco jurídico-constitucional do estado socioambiental do direito. Porto Alegre: Livraria do Advogado, 2008.

30 A propriedade no direito ambiental, 3 ed., São Paulo, Revista dos Tribunais, 2008, p. 129. 
direto de propriedade no sentido da proteção do meio ambiente, o que não reduz o conteúdo econômico da propriedade nem causa qualquer dano patrimonial".

Na verdade, o pano de fundo de toda problemática consiste em desenvolver uma ética da sobrevivência, um sistema de controle social sobre o fato humano, revertendo a lógica da privatização dos benefícios com a socialização dos prejuízos, projetando seus efeitos para todo o planeta alcançando as gerações futuras.

Nesse mesmo diapasão vale a lição de BERNARD DROBENKO ${ }^{31}$ que, ao tratar da 'ética da sobrevivência', afirma: "Essa ética é eminentemente cultural, dinâmica e intergeracional. Essa ética só pode inscrever-se em um sistema multilateral que permita a cada um agir, controlar e, se necessário, adotar medidas repressivas para os atores, quaisquer que sejam. Desse ponto de vista, trata-se, pois, de reforçar a capacidade ativa e interativa do Direito Internacional, a fim de que nenhum Estado e nenhum ator (público ou privado) escapem a suas responsabilidades. A Humanidade acha-se confrontada com uma exigência de intervenção política. A questão dos direitos (meio ambiente, direitos humanos) não mais aparece como questão secundária, mas como uma questão fundamental, que assegura a perpetuação de toda forma de vida sobre o Planeta".

Não obstante a amplitude do viés ambiental aqui apontado, internacional e intergeracional, esta tese se limita ao estudo da disciplina do uso e ocupação do solo e das atividades desenvolvidas na zona costeira urbana, pelo Município.

31 A caminho de um fundamento para o direito ambiental, cit. p. 84 . 
1.2.2. Planejamento no ambiente costeiro

O Plano Nacional de Gerenciamento Costeiro - PNGC II constitui importante instrumento de tutela jurídica da região costeira, pois resulta de contínuo processo de planejamento da região e consolida os avanços obtidos em experiências anteriores, conforme será demonstrado a seguir.

a) Plano e planejamento

A ideia de planejamento denota atividade contínua, incessante procura pela solução de um determinado problema. É a atividade racional e provida de métodos que não se esgota no plano, pois este não representa mais do que a manifestação de metas alcançadas. Dessa forma, o processo de planejamento dá ensejo à consecução de uma série de planos sucessivos no tempo ou setorizados na ação tópica.

JOSÉ AFONSO DA SILVA bem distingue planejamento de plano: ${ }^{32}$ "Planejamento é um processo técnico instrumentado para transformar a realidade existente no sentido dos objetivos previamente estabelecidos. De início, tal processo dependia simplesmente da vontade do administrador, que poderia utilizá-lo ou não. Não era, então, um processo 32 Direito urbanístico brasileiro, 6 ed. São Paulo, Malheiros, 2010, p. 87. 
juridicamente imposto, mas simples técnica de que o administrador se serviria ou não. Se o usasse, deveria fazê-lo mediante atos jurídicos, que se traduziriam num plano, que é o meio pelo qual se instrumentaliza o processo de planejamento". ${ }^{33}$

\section{Para FLORIANO DE AZEVEDO MARQUES NETO e JOÃO EDUARDO LOPES}

QUEIROZ: “o planejamento, em seu aspecto jurídico, é institucional, na medida em que o Estado se organiza para a obtenção de objetivos econômicos; e normativo, na medida em que há a inserção sistemática de regras jurídicas para implementar o plano estabelecido". ${ }^{34}$

O planejamento, assim, deixa de ser ato de mera vontade dos governantes, tornando-se imposição jurídica. Suas regras assumem a natureza de normas técnico-jurídicas, pois, aprovados por lei, dela fazem parte integrante.

A Constituição Federal, ao dispor sobre o assunto no art. 174, declara que o planejamento será determinante para o setor público e indicativo para o setor privado; imperativo, quando as previsões correspondem a comandos que vinculam juridicamente os sujeitos, ou indicativo, se apenas sugerem, podendo ainda ser mistos.

$33 \mathrm{Na}$ mesma linha, Angel Sustaeta Elustiza assevera que o planejamento é uma previsão de algo que se cogita realizar, um ponto de partida indispensável da obra desejada. O plano é incompatível com o improviso, resulta de um projeto de trabalho, de uma ordenação de atos sucessivos com vistas a um resultado final e futuro (Propriedad y urbanismo, p. 213).

34 Planejamento. In José Eduardo Cardozo, Márcia Walquíria Batista dos Santos e João Eduardo Lopes Queiroz, Curso de Direito Administrativo Econômico, vol. II, São Paulo, Malheiros, 2011, p. 40127. Os autores ainda indicam diversos dispositivos constitucionais que aludem ao planejamento, a saber, art. 21, IX; art. 25, § 3ㅇ; art. 29, XII; art. 30, VIII; art. 48; art. 49, IX; art. 58; art. 68, § 110; art. 74, art. 84, XI e XXIII; art. 159, I, "c"; art. 165; art. 174; art. 182; art. 187; art. 214; art. 226, § $7^{\circ}$. Ademais, elencam os princípios vetores do planejamento: racionalidade, universalidade, unidade, previsão, continuidade, inerência, eficiência, exequibilidade e desenvolvimento (p. 93-97). 
Assim, planificação de tipo indicativo se realiza através de uma ação administrativa de fomento, na qual os benefícios e estímulos que se oferecem ao setor privado constituem a contraprestação das obrigações que os particulares assumem, ao aceitar livremente tais benefícios.

É bom salientar que a adesão voluntária às indicações do plano não gera, só por si, direito subjetivo aos benefícios e estímulos prometidos, pois apenas em situações específicas e concretas, pode surgir o direito do particular de auferir os benefícios e estímulos prometidos. Em caso algum, contudo, lhe corre o direito subjetivo à execução do plano, que se dará por razões de conveniência e interesse público, e essa avaliação se dá com maior efetividade pelo plano local.

Por outro lado, se o plano indicativo não obriga o setor privado, é também certo que a liberdade de sua atuação fica condicionada à atuação governamental planejada, pois esse segmento não pode atuar deliberadamente contra os objetivos do plano. Ademais, nas hipóteses em que a atividade depende de autorização ou licença, a Administração poderá ter em conta os objetivos e previsões para concedê-la ou não.

MARIA GARCIA ${ }^{35}$ ressalta a importância do planejamento no processo de urbanização: “A urbanização é um dos meios de que dispõe o Poder Público para intervir nas cidades, de forma

35 O meio ambiente urbano, in José Eduardo Martins Cardozo e outros, cit., p. 715-754. 
a regular muitos dos seus aspectos, tais como a circulação, a oxigenação, a insolação, os diversos serviços destinados à melhoria da qualidade de vida urbana, mediante um processo racional, sistematizado e renovado de intervenção - o planejamento".

A falta de planejamento urbanístico constitui a razão principal do caos vivido pela expressiva maioria das cidades brasileiras, resultando em problemas crônicos nas áreas de transporte, moradia, saneamento, poluição, segurança pública, entre outros.

b) Arcabouço legal

No plano constitucional, o art. $225, \S 4^{\circ}$, da Constituição Federal erigiu a zona costeira à condição de patrimônio nacional, determinando que sua utilização assegure a preservação do meio ambiente. ${ }^{36}$

No plano infraconstitucional, a proteção da zona costeira tem sido objeto de contínuo regramento, conforme delineado na breve análise histórica deste tópico, necessária para os propósitos deste trabalho.

A Lei $n^{\circ}$ 6.938, de 31.08.1981, dispôs sobre a Política Nacional do Meio Ambiente - PNMA, regulamentado o inc. II do art. $9^{\circ}$ pelo Decreto $\mathrm{n}^{\circ} 4.297$, de 10.07.2002, que disciplinou seus

36 A temática ambiental é tratada em todo o texto constitucional, art. 23, III, VI e VII; 26,II; 170, VI; 174, $\S 3^{\circ}, 225$. 
fins e mecanismos de formulação e aplicação, e estabeleceu critérios para o Zoneamento Ecológico-Econômico do Brasil - ZEE.

A Lei $\mathrm{n}^{\circ}$ 7.661, de 16.06.1988, recepcionada pela Carta Magna de 1988, instituiu o Plano Nacional de Gerenciamento Costeiro (PNGC) como um dos mais importantes aspectos da Política Nacional dos Recursos do Mar - PNRM e, por consequência, da Política Nacional do Meio Ambiente - PNMA. ${ }^{37}$ O Decreto $n^{\circ} 96.660$, de 06.09.1988, ao regulamentar o art. $4^{\text {o }}$ da Lei $n^{\circ} 7.661$, de 16.05.1988, criou o Grupo de Coordenação ${ }^{38}$ incumbido de elaborar referido Plano, que restou aprovado pela Resolução n. 01, de 21.11.1990.

Assim, o PNGC foi constituído pela Lei 7.661, de 16.05.1988, cujo detalhamento e operacionalização foram objeto da Resolução n. 01, de 21.11.1990, da Comissão Interministerial para os Recursos do Mar - CIRM, aprovada após audiência do Conselho Nacional de Meio Ambiente - CONAMA. O mencionado decreto foi revogado pelo Decreto $\mathrm{n}^{\circ}$ 99.731, de 25.11.1990, posteriormente revogado pelo Decreto $\mathrm{n}^{\circ} 1.540$, de 27.06.1995.

370 inciso I do art. $3^{\circ}$ indica os bens sobre os quais deverá incidir o zoneamento de usos e atividades Art. 3‥ O PNGC deverá prever o zoneamento de usos e atividades na zona costeira e dar prioridade à conservação e proteção, entre outros, dos seguintes bens:

I - recursos naturais, renováveis e não renováveis; recifes, parcéis e bancos de algas; ilhas costeiras e oceânicas; sistemas fluviais, estuarinos e lagunares, baías e enseadas; praias; promontórios, costões e grutas marinhas; restingas e dunas; florestas litorâneas, manguezais e pradarias submersas;

$O$ art. $5^{\circ}$ estabelece os aspectos que deverão ser contemplados, prevalecendo, no concerto das competências federativas, as disposições mais restritivas.

Art. 50. O PNGC será elaborado e executado observando normas, critérios e padrões relativos ao controle e à manutenção da qualidade do meio ambiente, estabelecidos pelo CONAMA, que contemplem, entre outros, os seguintes aspectos: urbanização; ocupação e uso do solo, do subsolo e das águas; parcelamento e remembramento do solo; sistema viário e de transporte; sistema de produção, transmissão e distribuição de energia; habitação e saneamento básico; turismo, recreação e lazer; patrimônio natural, histórico, étnico, cultural e paisagístico.

${ }^{38}$ Este Grupo é composto por dez representantes de órgãos públicos, sendo nove provenientes de órgãos federais (dois da Marinha - sendo um o seu Secretário, e mais um de cada um dos seguintes Ministérios: Fazenda, Agricultura, Interior, Indústria e Comércio, Habitação e Bem-Estar Social, Secretaria do Planejamento e Coordenação da Presidência da República) e um representante da ABEMA - Associação Brasileira de Entidades de Meio Ambiente, entidade que congrega os órgãos públicos estaduais ligados à proteção ambiental. 
O Plano Nacional de Gerenciamento Costeiro, optou por delegar aos Planos Estaduais a definição dos limites físicos do que venha a ser o ecossistema denominado de zona costeira, porquanto a heterogeneidade da costa brasileira (seja no tocante às paisagens e aspectos naturais ou mesmo em relação à forma de sua ocupação), bem como sua extensão, exigem a integração dos níveis locais e regionais com o nacional para que o Plano tenha eficácia.

Na proteção aos manguezais ${ }^{39}$ e estuários, a aplicação do PNGC deve ser conjugada com a Convenção Iraniana de Ramsar, celebrada em 02.02.1972, com o intuito de despertar a atenção internacional a respeito da vertiginosa degradação das zonas úmidas, bem como sua vasta importância econômica, social, científica e recreativa. A referida Convenção é considerada uma regra de soft law, tendo em vista a sua flexibilidade, pois não representa um regime regulatório, nem prevê sanções pelo não cumprimento do tratado. Entretanto suas disposições constituem um tratado solene e nesse sentido - e só nesse, pois desprovido de sanção - tem caráter obrigatório com base no direito internacional. ${ }^{40}$

39 Conferir Antonio Carlos Sant'Ana Diegues (Org.). Povos e águas: inventário de áreas úmidas. 2 ed. São Paulo: Núcleo de apoio à pesquisa sobre populações humanas e áreas úmidas brasileiras. Universidade de São Paulo, 2002.

40 Francelise Pantoja Diehl, Grazielle Xavier e Nívia Daiane Régis Brancher observam que toda sua estrutura é baseada em uma transparente responsabilidade comum e o não cumprimento desta expectativa pode gerar conflitos políticos e diplomáticos em fóruns internacionais de alta competência. O não cumprimento da Convenção pode afetar a sua eficácia, ou seja, os esforços para angariar fundos para a preservação das zonas úmidas ficam ameaçados com o descumprimento das diretrizes da Convenção (Proteção jurídica dos manguezais e estuários: uma abordagem a partir do PNGC e da Convenção de Ramsar, Revista de Direito Ambiental, ㄲo 44, São Paulo, Revista dos Tribunais, out.-dez. 2006, p. 09-39; Ver também Francelise Pantoja Diehl, Grazielle Xavier, Nívia Daiane Régis Brancher e Sharon de Rosa Pereira, Valoração econômico-ambiental das zonas úmidas costeiras: análise da interrelação entre a Convenção Ramsar e a legislação brasileira de proteção da zona costeira. Revista de Direito Ambiental, no 48, São Paulo, Revista dos Tribunais, out.-dez. 2007, p. 102-117) 
Por intermédio da Resolução $\mathrm{n}^{\circ}$ 5, de 03.121997, a Comissão Interministerial para os Recursos do Mar - CIRM, em sua $135^{\text {a }}$ Sessão Ordinária, aprovou o Plano Nacional de Gerenciamento Costeiro II - PNGC-II. Tal revisão, já prevista ${ }^{41}$, buscou adequar o PNGC à sua prática, contemplando atividades e demandas novas surgidas no âmbito da sociedade, cujo marco balizador está nos documentos gerados pela Conferência das Nações Unidas para o Meio Ambiente e Desenvolvimento, conhecida como RIO-92, destacando-se, neste caso, a “Declaração do Rio sobre o Meio Ambiente e Desenvolvimento" e a “Agenda-21".

Enfim, o PNGC II consolidou os avanços obtidos no âmbito do PNGC, possibilitou o seu aprimoramento e ofereceu as condições necessárias para o atendimento das novas demandas que se apresentaram ao longo da extensa e heterogênea zona costeira brasileira, considerando sua morfologia e viés da ocupação econômica e social, circunstâncias que reforçam o papel do plano local em seu gerenciamento. ${ }^{42}$

\footnotetext{
${ }^{41}$ Decreto n. 96.660 , de 06.09.88, art. 4: "Compete ao COGERCO, em face da implementação e do acompanhamento do PNGC: (...) II - providenciar a sua atualização, sempre que necessário.

42 Cabe alusão à normatização editada após o PNGC II: Lei no 9.605, de 12.02.1998 - disciplina as sanções penais e administrativas derivadas de condutas e atividades lesivas ao meio ambiente, regulamentada pelo Decreto $\mathrm{n} 03.179$, de 21.09.1999, posteriormente revogado pelo Decreto oㅡ 6.514, de 22.07.2008; Lei no 9.966, de 28.04.2000, dispõe sobre a prevenção, o controle e a fiscalização da poluição causada por lançamento de óleo e outras substâncias nocivas ou perigosas em águas sob jurisdição nacional, regulamentada pelo Decreto no 4.871, de 06.11.2003; Resolução CONAMA no 306, de 05.07.2002, estabelece os requisitos para a realização de auditorias ambientais, objetivando avaliar os sistemas de gestão e controle ambiental nos portos, plataformas e refinarias, tendo em vista o cumprimento da legislação vigente e do licenciamento ambiental pela indústria de petróleo e gás natural e seus derivados; Decreto № 4.983, de 10.02.2004, estabelece os pontos apropriados para 0 traçado das Linhas de Base Retas ao longo da costa brasileira; Decreto no 5.300, de 07.12.2004 regulamenta a Lei no 7.661 , de 16.05.1988, ao dispor sobre regras de uso e ocupação da zona costeira e estabelece critérios de gestão da orla marítima; Lei ํo 11.428, de 22.12.2006, art. 2º, normatiza a utilização e proteção da vegetação nativa do Bioma da Mata Atlântica, especialmente consideradas a vegetação da zona costeira, incluídos os manguezais e vegetações de restinga; Lei ํo 12.651 , de 25.05.2012, institui o Código Florestal, com as alterações da Lei no 12.727, de 17.10.2012.
} 
c) Plano Nacional de Gerenciamento Costeiro

O gerenciamento costeiro, cujos princípios encontram-se no item 2 do Plano Nacional de Gerenciamento Costeiro - PNGC, constitui o instrumento fundamental de que o Estado dispõe para organizar o uso do espaço territorial e marítimo costeiro, devendo ser utilizado como mecanismo de participação e consulta permanente à população local, com vistas à solução de conflitos, conservação da natureza, melhoria do meio ambiente e da qualidade de vida daqueles que habitam a região costeira. ${ }^{43}$

A expressão gerenciamento foi cunhada do termo management da lei norte americana, definida como o conjunto de atividades e procedimentos que, através de instrumentos específicos, permite a gestão da utilização dos recursos da zona costeira. ${ }^{44}$

O Plano Nacional de Gerenciamento Costeiro terá normas gerais, de competência legislativa da União, a quem caberá o norte da filosofia a ser seguida (e mesmo dos Estados em relação às diretrizes a serem observadas pelos Municípios), bem como normas especiais a serem ditadas pela União (em relação aos seus bens) ou pelos entes federativos a ela subordinados.

\footnotetext{
${ }^{43}$ Reforça esse entendimento o escólio de José Afonso da Silva: "O Plano Nacional de Gerenciamento Costeiro constitui o principal instrumento de monitoramento do gerenciamento costeiro porque estabelece as diretrizes de ocupação do solo e de uso dos recursos naturais e ecossistemas costeiros; visa à identificação de unidades espaciais (zonas) que, por suas características físicas, bióticas e socioeconômicas, sua dinâmica e contrastes internos, devem ser objeto de atenção especial com vistas ao desenvolvimento de ações capazes de conduzir ao aproveitamento, manutenção e recuperação do seu potencial; porque constitui parâmetro ao qual se reportam todos os órgãos públicos e privados na orientação de sua atuação, bem como serve de base de referência para os planos diretores estaduais, regionais e municipais" (Direito ambiental constitucional, 9 ed., São Paulo, Malheiros, 2011, p. 105-106).

${ }^{44}$ Idem, p. 103.
} 
Neste caso, as normas gerais ditadas pela União serão cogentes aos Estados e Municípios ${ }^{45}$, e as especiais apenas se versarem sobre bens de seu patrimônio. No curso deste trabalho será visto o avanço do interesse local representado pelo Município, limitada atuação da União à edição de normas gerais.

Ao abordar a questão da ausência de normas gerais, PAULO AFFONSO LEME MACHADO observa: “A ausência de um plano, ou a não terminação de um plano em elaboração, ou a omissão de exigência de um plano, não conferem aos particulares ou ao Poder Público plena liberdade de ocupação e uso da Zona Costeira. As normas ambientais federais, estaduais e municipais já existentes deverão ser sempre pesquisadas e colocadas em prática no momento da concessão da autorização para instalar, operar ou construir, como, também, no momento de aplicar sanções.. ${ }^{46}$

A conservação e proteção da região costeira deverão compreender: os recursos naturais renováveis ou não renováveis; ilhas costeiras ou oceânicas; recifes, parcéis e bancos de algas; sistemas fluviais, estuarinos e lagunares; baías e enseadas; praias; promontórios, costões e grutas marinhas; restingas e dunas; florestas litorâneas, manguezais e pradarias submersas; sítios ecológicos de relevância cultural e demais unidades naturais de preservação

45 Cf. infra 2.1.

${ }^{46}$ Direito ambiental brasileiro, p. 1076. 
permanente; monumentos que integram o patrimônio natural, histórico, paleontológico, espeleológico, arqueológico, étnico, cultural e paisagístico. ${ }^{47}$

Com a finalidade acompanhar as modificações sócio econômicas havidas no plano fático na zona costeira, como o uso e ocupação do solo, das águas, disciplina das atividades socioculturais, visando ao equilíbrio ambiental da região na acepção mais ampla, os Planos Estaduais e Municipais de Gerenciamento Costeiro serão instituídos por lei, que estabelecerá: os princípios, objetivos e diretrizes da política de gestão da zona costeira da sua área de atuação; o Sistema de Gestão Costeira na sua área de atuação; os instrumentos de gestão ${ }^{48}$; as infrações e penalidades previstas em lei; os mecanismos econômicos que garantam a sua aplicação. $^{49}$

Importante salientar, para o objetivo deste trabalho, que a elaboração de tais planos também competirá aos Estados e Municípios ${ }^{50}$, ressaltando a importância deste enquanto gestor do território, sendo tais atividades sistematizadas em planos e programas tanto setoriais como integrados, tais como: planos de implantação de unidade de conservação, de educação ambiental, de desenvolvimento científico e difusão de tecnologias adequadas, de recuperação de áreas degradadas, de investimentos em coleta, tratamento e disposição de efluentes sólidos e líquidos, de manejo de microbacias, programas de apoio a emergências e acidentes de ecoturismo, etc.

\footnotetext{
${ }^{47}$ Art. 3을 incs. I, II e III, da Lei oํ 7.661, de 16.05.1988.

48 Entre os instrumentos de gerenciamento ambiental serão considerados aqueles previstos no art. 9o

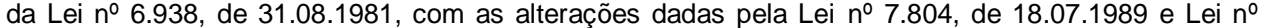
11.284, de 02.03.2006.

49 Art. $8^{\circ}$ do Decreto ํㅜ 5.300, de 07.12.2004.

50 Cf. infra 2.3.
} 
No âmbito do Plano Nacional de Gerenciamento Costeiro, o Zoneamento ${ }^{51}$ Ecológico Econômico Costeiro deverá ser elaborado de forma participativa, estabelecendo as diretrizes dos usos permitidos, proibidos ou estimulados, abrangendo as interações entre as faixas terrestre e marítima da zona costeira, devendo os ZEEC já existentes ser gradualmente compatibilizados com as orientações contidas no Decreto $\mathrm{n}^{\circ}$ 5.300, de 07.12.2004.

Os resultados obtidos no monitoramento dos usos e ocupação do território na zona costeira, pelos Estados e Municípios serão encaminhados ao Instituto Brasileiro do Meio Ambiente e dos Recursos Naturais Renováveis - IBAMA, que os consolidará e divulgará na forma do Relatório de Qualidade Ambiental - Zona Costeira (RQA-ZC), com periodicidade bianual. Deverão ser considerados indicadores de qualidade que permitam avaliar a dinâmica e os impactos das atividades socioeconômicas, considerando, entre outros, os setores industrial, turístico, portuário, de transporte, de desenvolvimento urbano, pesqueiro, aquicultura e indústria do petróleo. ${ }^{52}$

Impende ressaltar que o legislador não fez qualquer menção quanto ao repasse de fundos federais para Estados e Municípios, e tampouco criou fundo especial destinado ao custeio do gerenciamento costeiro ao considerar as seguintes fontes de recursos na execução do PNGC

51 José Afonso da Silva observa que o zoneamento consiste na repartição do território municipal, à vista da destinação da terra e do uso do solo, definindo, no primeiro caso, a qualificação do solo em urbano, de expansão urbana, urbanizável e rural e, no segundo, dividindo o território municipal em zonas de uso (cit., p. 182).

52 Ver a respeito do assunto: Alberto Augusto Eichman Jakob. Análise sócio-demográfica do espaço urbano da Região Metropolitana da Baixada Santista no período de 1960-2000. Tese de Doutorado Instituto de Filosofia e Economia Humana - UNICAMP, 2003. 
II: a) orçamento geral da União; b) orçamentos estaduais e municipais e Agências estaduais e municipais de financiamento; c) Fundo Nacional de Meio Ambiente - FNMA, criado pela Lei 7.797/89; d) Agências federais de financiamento; e) Agências internacionais de financiamento; f) entidades e instituições financeiras públicas e privadas; e g) doações e legados.

Não há que se olvidar do aspecto primordial da questão, qual seja, a ineficácia de qualquer plano envolvendo os entes da federação, se não forem destinados ou repassados recursos conforme as competências que lhe fossem atribuídas, reforçando a importância do plano local ante a impossibilidade de um licenciamento federal para todas as atividades. ${ }^{53}$

A guisa de breve conclusão deste tópico, acresce notar outras razões para o chamado déficit de efetividade quanto à operacionalidade do ordenamento ambiental brasileiro, apontado por ODETE MEDAUAR: mais empenho governamental na preservação e defesa do meio ambiente; mais empenho governamental na efetivação da educação ambiental; maior empenho na difusão da informação ambiental, tanto por parte dos órgãos públicos como do setor privado; inserção do direito ambiental na grade curricular dos cursos de Direito. ${ }^{54}$

\footnotetext{
${ }^{53}$ Paulo Afonso Leme Machado chama atenção para o problema: "Não há um meio mais eficaz de levar à prática o planejamento costeiro nacional pelos estados e municípios do que fornecer-lhes recursos financeiros, quando cumprirem as normas do PNGC. No sistema federativo não há outro meio de controle federal do que este - de natureza indutiva - a menos que se instituíssem um licenciamento federal para todas as atividades a serem desenvolvidas na zona costeira brasileira, o que seria impraticável. A instrumentação legal da proteção da zona costeira, portanto, haverá de ser completada com mecanismos financeiros que possibilitarão aos estados e municípios bem cumprirem suas obrigações ambientais e culturais no litoral" (cit. p. 1079).
}

$54 \mathrm{O}$ ordenamento ambiental brasileiro, in Desafios do direito ambiental no século XXI - estudos em homenagem a Paulo Affonso Leme Machado, p. 698-708. 
Desta forma, no que pese a importância da destinação de recursos para conferir eficácia à implementação do Plano, tal medida restará inócua se desacompanhada de outras providências igualmente relevantes, especialmente afetas à informação e educação.

\subsection{Tutela da orla marítima e o terreno de marinha}

Este tópico salienta a importância do Projeto Orla como instrumento de gestão da orla marítima, especialmente para os Municípios menos desenvolvidos. Aborda a evolução histórica e os fundamentos que procuram justificar a manutenção do instituto do terreno de marinha e acrescidos, as dificuldades encontradas na exata identificação da preamar médio de 1831, e as formas de contraprestação decorrentes de sua utilização, como o aforamento e a ocupação.

1.3.1 Tratamento jurídico da orla marítima

O Decreto $n^{\circ}$ 5.300, de 07.12.2004, ao regulamentar a Lei $n^{\circ} 7.661$, de 16. 05.1988, e estabelecer os limites, princípios, objetivos, instrumentos, competências, regras de uso e ocupação da zona costeira e gestão da orla marítima, fornece os subsídios necessários à 
implementação do Projeto ORLA ${ }^{55}$, resultado do Programa da Secretaria de Qualidade Ambiental nos Assentamentos Humanos do Ministério do Meio Ambiente, em conjunto com a Secretaria do Patrimônio da União do Ministério do Planejamento, Orçamento e Gestão.

O Projeto foi criado para responder a demandas de ordenamento do uso e ocupação das bordas litorâneas, que se tornaram evidentes na prática da gestão ambiental e patrimonial, como reflexo da fragilidade dos ecossistemas, da falta de planejamento, do crescimento desordenado das cidades, do aumento dos processos erosivos e das fontes contaminantes de orla.

A partir de um plano de intervenção construído de maneira participativa, o Projeto permite uma visão macroscópica do problema, ao definir critérios, priorizar investimentos públicos e privados no litoral, elaborando diagnóstico, classificação e definição de cenários de uso e ocupação da orla, por meio de relatórios que abrangem os seguintes tópicos: óleo e gás, biodiversidade, geomorfologia, dinâmica populacional, risco social, risco natural, risco tecnológico e gestão costeira.

No âmbito do referido Projeto, as atribuições reservadas aos entes federativos superiores

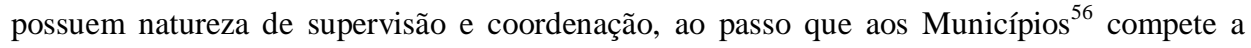

55 O Projeto foi inserido em 1999 no âmbito do Grupo Interministerial de Gerenciamento Costeiro (GIGERCO) como parte das ações prioritárias do Plano de Ação Federal para a Zona Costeira (PAFZC), aprovado pela Resolução CIRM no 5/1998.

56 Cf. infra 2.3 e 2.4 . 
execução do projeto, o levantamento da documentação necessária, a elaboração do plano, o entabulamento de convênios, e a definição da agenda. ${ }^{57}$

Dessa forma, os arranjos institucionais propostos pelo Projeto Orla ${ }^{58}$ visam propiciar e estimular a elaboração de parcerias entre diferentes instâncias governamentais e a sociedade civil, durante todo o seu desenvolvimento. ${ }^{59}$

A coordenação estadual deverá definir estratégias diferenciadas para atendimento aos Municípios selecionados, divididos em três níveis, considerando: a capacidade técnica das equipes; os arranjos institucionais locais/regionais; a disponibilidade de informações; e o comprometimento dos municípios na inserção das diretrizes do projeto no planejamento do território, dos usos do solo e dos recursos naturais.

A coordenação estadual também deverá elaborar um dossiê sobre o Município ${ }^{60}$, complementada por uma visita técnica à área de trabalho antes da oficina de capacitação.

57 Relatórios anuais da SPU/Ministério do Planejamento indicam os municípios que estão demandando a inserção no Projeto Orla e os obstáculos encontrados, em regra a falta de recursos e de pessoal qualificado.

58 Cf. infra 2.4.

59. São atribuições da Coordenação Municipal: formular propostas de adesão ao Projeto junto à Coordenação estadual; elaborar agenda de atividades para o Projeto; apresentar e justificar a composição preliminar do grupo de atores a ser capacitado; organizar e listar os documentos técnicos, cartográficos, base legal e logística para realização da oficina de capacitação; elaborar o Plano de Gestão Integrada da Orla; convocar audiências públicas para legitimação do Plano de Gestão Integrada, composição do Comitê Gestor da Orla, dos projetos e ações; criar o Comitê Gestor da Orla; analisar a base legal e os instrumentos necessários à celebração de futuros convênios; coordenar a execução das ações propostas no Plano de Gestão (Guia de Implementação do Projeto Orla. Ministério do Meio Ambiente / Secretaria de Qualidade Ambiental nos Assentamentos Humanos, Ministério do Planejamento, Orçamento e Gestão / Secretaria do Patrimônio da União). 
A adesão dos Municípios por meio de convênios terá caráter voluntário ${ }^{61}$, comprometendo-se com o desenvolvimento de todas as fases de implementação, de acordo com as diretrizes traçadas: a) compatibilizar as políticas ambiental e patrimonial do Governo Federal no trato dos espaços litorâneos; b) compatibilizar com o município as atribuições de gestão dos terrenos de marinha e acrescidos, por intermédio de instrumentos legais específicos; c) desenvolver mecanismos de participação e controle social para uma gestão integrada da orla; d) estimular atividades de participação e controle social para uma gestão integrada da orla; e) valorizar o conceito de patrimônio coletivo da orla, com a garantia efetiva do acesso público às praias e manutenção de sua função social.

A seleção dos Municípios interessados terá início pela análise da ficha de adesão, de acordo com critérios pré-estabelecidos, considerando as características locais. Após, será aferido o conhecimento adquirido a partir de atividades de planejamento e gestão estaduais (como o Zoneamento Ecológico Econômico), e, ao final, o atendimento às políticas estratégicas como turismo, transporte, portuária, desenvolvimento urbano e implantação de polos de investimento econômico.

60 Esse dossiê deverá conter os seguintes documentos: Plano Diretor, Zoneamento Municipal, Lei de Uso e Ocupação do Solo, Lei de Parcelamento do Solo, Lei Orgânica, Zoneamento Ecológico Econômico, Zoneamento Costeiro, Plano de Desenvolvimento do Turismo, Macrodiagnóstico estadual/regional, Código de Obras e Posturas do Município, Lei de Diretrizes Orçamentárias, outras legislações de urbanismo, Diagnóstico Preliminar da GRPU.

61 Fases para assinatura do Convênio do Projeto Orla: 1. Após a legitimação do Plano de Gestão Integrada e do Comitê Gestor da Orla, a Prefeitura Municipal encaminha ofício à MP/SPU, manifestando interesse em assinar o Convênio de Cooperação Técnica do Projeto Orla (devem anexar as cópias do Plano e da ata da audiência pública); 2. MP/SPU e a MMA/SQA emitem Nota Técnica quanto à habilitação do Município para celebrar o convênio e encaminham o processo para análise das respectivas consultorias jurídicas; 3. Após aprovado nas consultorias jurídicas, o Município deverá encaminhar a cópia do documento de criação do Comitê Gestor da Orla para que seja marcada a data de assinatura do Convênio e, posteriormente, será publicado no Diário Oficial da União. 
Para execução das ações de gestão na orla marítima em áreas de domínio da União poderão ser celebrados convênios ou contratos ${ }^{62}$ entre a Secretaria do Patrimônio da União, os Municípios e a iniciativa privada ${ }^{63}$, nos termos da legislação vigente, considerando como requisito o Plano de Intervenção da Orla Marítima e suas diretrizes para a região.

62 Ao tratar dos consórcios e convênios administrativos, Odete Medauar explica: "Os convênios e consórcios administrativos revelam-se instrumentos de grande importância, sobretudo num Estado Federal, na qualidade de modelos cooperativos de tipo vertical e horizontal. Os convênios entre entidades de diferentes níveis administrativos favorecem a realização de atividades materiais no âmbito das competências cumulativas ou concorrentes; atenuam ou evitam conflitos que emperrariam a adoção de providências de elevado interesse da população, como as medidas de combate à poluição nas grandes cidades, as medidas na área da saúde, do ensino, da preservação do patrimônio cultural. Os consórcios propiciam a reunião de recursos financeiros, humanos e técnicos para a solução de problemas comuns dos seus integrantes, tornando menos onerosas as atividades. Relembre-se que os consórcios podem integrar convênios. Quanto aos convênios de entes estatais com o setor privado, configuram um dos modos de realização de parcerias, em especial no âmbito da saúde, educação, cultura, artes, ciência, preservação do patrimônio cultural, preservação ambiental" (Convênios e consórcios administrativos, Revista Jurídica da Procuradoria Geral do Município de São Paulo, vol. 2 , 1996, p. 87).

63 Lei no 9.636, de 15.05.1998 (...) Art. 4o Os Estados, Municípios e a iniciativa privada, a juízo e a critério do Ministério da Fazenda, observadas as instruções que expedir sobre a matéria, poderão ser habilitados, mediante convênios ou contratos a serem celebrados com a SPU, para executar a identificação, demarcação, cadastramento e fiscalização de áreas do patrimônio da União, assim como o planejamento e a execução do parcelamento e da urbanização de áreas vagas, com base em projetos elaborados na forma da legislação pertinente. § $1^{\circ}$ Na elaboração e execução dos projetos de que trata este artigo, serão sempre respeitados a preservação e o livre acesso às praias marítimas, fluviais e lacustres e a outras áreas de uso comum do povo. $\S 2$ Como retribuição pelas obrigações assumidas, os Estados, Municípios e a iniciativa privada farão jus a parte das receitas provenientes da: I - arrecadação anual das taxas de ocupação e foros, propiciadas pelos trabalhos que tenham executado; II - venda do domínio útil ou pleno dos lotes resultantes dos projetos urbanísticos por eles executados. $\S 3^{\circ}$ A participação nas receitas de que trata o parágrafo anterior será ajustada nos respectivos convênios ou contratos, observados os limites previstos em regulamento e as instruções a serem baixadas pelo Ministro de Estado da Fazenda, que considerarão a complexidade, o volume e o custo dos trabalhos de identificação, demarcação, cadastramento, recadastramento e fiscalização das áreas vagas existentes, bem como de elaboração e execução dos projetos de parcelamento e urbanização e, ainda, o valor de mercado dos imóveis na região e, quando for o caso, a densidade de ocupação local. § 4․ A participação dos Estados e Municípios nas receitas de que tratam os incisos I e II poderá ser realizada mediante repasse de recursos financeiros. $\S 5^{\circ} \mathrm{Na}$ contratação, por intermédio da iniciativa privada, da elaboração e execução dos projetos urbanísticos de que trata este artigo, observados os procedimentos licitatórios previstos em lei, quando os serviços contratados envolverem, também, a cobrança e o recebimento das receitas deles decorrentes, poderá ser admitida a dedução prévia, pela contratada, da participação acordada. 
Portanto, a impossibilidade do Estado em destinar recursos necessários ao atendimento das demandas por serviços públicos e às adequações urbanísticas, justifica a celebração de convênios com o setor privado.

As obras e serviços de interesse público somente poderão ser realizados ou implantados em área da orla marítima, quando compatíveis com o Zoneamento Ecológico Econômico - ZEEC ou outros instrumentos similares de ordenamento do uso do território. Em áreas não contempladas por plano de intervenção, o órgão ambiental requisitará estudos que permitam a caracterização e classificação da orla marítima para o licenciamento ambiental de empreendimentos ou atividades. ${ }^{64}$

De todo modo, qualquer empreendimento na zona costeira deverá ser compatível com a infraestrutura de saneamento e sistema viário existentes, devendo a solução técnica adotada preservar as características ambientais e a qualidade paisagística.

Na hipótese de inexistência ou inacessibilidade à rede pública de coleta de lixo e de esgoto sanitário na área do empreendimento, o empreendedor deverá apresentar solução autônoma para análise do órgão ambiental, compatível com as características físicas e ambientais da área.

64 Art. 33 e 34 do Decreto no 5.300, de 07.12.2004. 
A área a ser desmatada para instalação, ampliação ou realocação de empreendimentos ou atividades na zona costeira que implicar a supressão de vegetação nativa, quando permitida em lei, será compensada por averbação de, no mínimo, uma área equivalente, na mesma zona afetada. Para efeito de compensação, a área escolhida poderá se situar em zona diferente da afetada, desde que na mesma unidade geoambiental, mediante aprovação do órgão ambiental. A área averbada como compensação poderá ser submetida a plano de manejo, desde que não altere a sua característica ecológica e sua qualidade paisagística.

A disciplina na circulação de veículos, prática de esportes, propaganda, instalação de quiosques, comercialização de produtos, realização de eventos de curta duração, instalação de equipamentos e o uso de veículos automotores em dunas móveis, entre outros, estarão sujeitos à disciplina própria do poder de polícia. ${ }^{65}$

Todavia, há que se conferir efetividade às disposições referidas, o que nem sempre ocorre, em especial nos Municípios menos desenvolvidos, desprovidos de recursos humanos e econômicos, muitas vezes governados por administradores sem o necessário comprometimento com o interesse público, seduzidos pelo turismo predatório e pela especulação imobiliária, fenômeno em parte explicado pela histórica centralização das competências na esfera federal (especialmente a legislativa) e pela precária eficácia dos mecanismos de controle em expressiva parcela da Administração Pública brasileira.

65 Infra 3.1. 
Destarte, diversos obstáculos podem ser apontados ao êxito do gerenciamento costeiro integrado: obstáculos político institucionais, como a falta de engajamento político em todos os níveis, a centralização das questões cruciais na esfera federal e o atrelamento das eleições municipais a interesses lobistas relativos às questões locais; obstáculos técnicoadministrativos, como a falta de especialistas e de parcerias entre instituições de pesquisa e universidades com os órgãos de gestão, predominância de cargos comissionados, acumulação de cargos e descontinuidades administrativas; obstáculos financeiros, como repasses descontínuos e irregulares, dificultando ações consistentes e remuneração adequada do pessoal técnico; obstáculos socioculturais, como a inadequada participação inadequada da sociedade por falta de capacidade, de informação e de organização. ${ }^{66}$

Com o intuito de superar os entraves técnico-administrativos, em 2011 foi realizado o Seminário Internacional Brasil-Espanha - Sistema de Modelagem Costeiro: apoio à gestão da Costa Brasileira, uma promissora iniciativa. Em 2012 ocorreu a Missão Técnica Santander SMC, visita técnica do governo brasileiro à costa espanhola para conhecer a experiência espanhola na gestão costeira integrada e seus casos exitosos, com 35 participantes, entre representantes de instituições brasileiras e espanholas, gestores, técnicos e professores universitários. Nesse mesmo ano, o I Curso de Formação SMC-Brasil apresentou a base conceitual para que, ao longo do desenvolvimento de estudos de caso, se possa identificar e validar o modelo.

66 Conferir Constança de Carvalho Belchior, cit, p.63-66. 
A propósito, convém trazer à baila experiências ocorridas em países cujo desenvolvimento econômico depende, em larga medida, das atividades realizadas na zona costeira.

Na Espanha ${ }^{67}$, país cuja economia (agrícola, industrial e turística) é dependente do espaço e recursos litorâneos, a gestão do litoral é basicamente uma função pública, considerando dez aspectos: política, normativa, competências, administração, estratégias, instrumentos, administradores, recursos, informações e participação. Entretanto, não há uma lei específica para a gestão costeira, sendo a Lei de Costas - Lei 22/88, uma lei pensada especialmente para a gestão do domínio público marítimo terrestre (DPMT) e não para a zona litorânea em sentido amplo, sendo, ainda assim importante, pois, constitui a legislação básica do litoral espanhol $^{68}$; identifica o DPMT com os espaços costeiros de maior valor ambiental e socioeconômico (mar territorial, águas interiores, recursos naturais da Zona Econômica Exclusiva e plataforma continental. Marismas, praias, dunas, etc.); constitui importante ponto de encontro das três escalas básicas da administração pública; condiciona de forma estrita o desenvolvimento do primeiro meio quilômetro do âmbito terrestre, por constituir a linha que

67 A respeito da gestão costeira na Espanha, conferir: P. Rodriguez Lopes, Playas y costas em el derecho español. A propósito de la Lei de Costas de 1988. Barcelona: BOSCH, 2010; Ángel Menédez Reixach, El rol de los poderes locales u regionales. Impactos urbanísticos en el litoral onubense: el dilema entre conservación y desarollo. Huelva, 1989; La nueva Ley de Costas: el domínio publico como regimen jurídico de especial proteción, ordenación y desarollo del turismo em España y Francia. Palma de Majorca, 1991; Carlos Fernandez de Casadevante Romani, La proteción del medio ambiente en derecho internacional, derecho comunitario europeo y derecho español. Vitoria-Gasteiz; Servicio Central de Publicaciones del Gobierno Vasco, 1991; Francisco JoséTorres Alfonsea, Ordenación del litoral en la Costa Blanca, Alicante. Publicaciones de la Universidad de Alicante, 1997.

68 Juan Jesús Trapero, ao comentar os efeitos da Lei de Costas, tece loas à regulamentação, por responder a uma demanda da sociedade em conferir o mínimo de proteção aos valores ambientais e sociais que ainda restam no litoral, estabelecer uma zona de influência de $500 \mathrm{~m}$ na qual as intervenções e construções devem se adaptar ao seu entorno, assegurar o uso público do domínio público marítimo e terrestre, impedir o uso e ocupação excessiva do território litorâneo e proporcionar o desfrute do espaço litorâneo e do mar e a prática tranquila e segura dos esportes aquáticos e náuticos (Aspectos urbanísticos de la proteción del territorio litoral. Revista de Derecho Urbanístico, n. 117, Madri, Montecorvo, mar.-abr. 1990, p. 57-62).

Formatado: Fonte: (Padrão) Arial, 10 pt, Espanhol (Espanha - tradicional)

Formatado: Fonte: (Padrão) Arial, 10 pt, Espanhol (Espanha - tradicional)

Formatado: Fonte: (Padrão) Arial, 10 pt, Espanhol (Espanha - tradicional)

Formatado: Fonte: (Padrão) Arial, 10 pt, Espanhol (Espanha - tradicional)

Formatado: Fonte: (Padrão) Arial, 10 pt, Espanhol (Espanha - tradicional)

Formatado: Fonte: (Padrão) Arial, 10 pt, Espanhol (Espanha - tradicional)

Formatado: Fonte: (Padrão) Arial, 10 pt, Espanhol (Espanha - tradicional)

Formatado: Fonte: (Padrão) Arial, 10 pt, Espanhol (Espanha - tradicional)

Formatado: Fonte: (Padrão) Arial, 10 pt, Espanhol (Espanha - tradicional)

Formatado: Fonte: (Padrão) Arial, 10 pt, Espanhol (Espanha - tradicional)

Formatado: Fonte: (Padrão) Arial, 10 pt, Espanhol (Espanha - tradicional) 
separa o DPMT do domínio privado e mede as distintas zonas de servidão e influência à propriedade privada.

Países como França ${ }^{69}$ e Portugal $^{70}$ dispõem de instrumentos específicos para a gestão das áreas litorâneas, enquanto o Reino Unido baseia sua administração na coordenação das disciplinas legais setoriais.

Ao tratar da gestão da zona costeira portuguesa, FILOMENA MARTINS e HENRIQUE

ALBUQUERQUE observam que o despacho $\mathrm{n}^{\circ}$ 19.212, de 05.09.2005, desenvolve as bases de uma estratégia de gestão integrada da zona costeira nacional continental e insular. ${ }^{71}$

69 Projeto Bandeira Azul - originário da França, tendo no IAR - Instituto Ambiental Ratones (OSCIP) o Operador Nacional, é programa de educação e certificação ambiental que une esforços de diversas entidades no sentido da melhoria do ambiente marinho, costeiro, fluvial e lacustre, mediante a observância, entre outros, dos seguintes critérios: qualidade da água, informação e educação ambiental, gestão ambiental e equipamentos (salva vidas, coleta de resíduos, ordenamento da orla e acesso seguro à praia, instalações sanitárias, primeiros socorros, etc.). Ver a propósito Marinez Scherer, Bandeira Azul: Um programa de certificação ambiental de praias contribuindo para a política brasileira de gerenciamento costeiro. In Gestão costeira integrada para países de língua portuguesa, no 5,2006 , p. 49-51.

$70 \mathrm{Em}$ Portugal, $75 \%$ da população do território continental (exceção aos Açores e llha da Madeira) estão concentradas na faixa litoral, região responsável por $90 \%$ dos turistas que visitam o país. Essa excessiva concentração populacional acarreta a destruição da paisagem, a sobre exploração dos recursos, a poluição do ambiente, alteração do uso do solo e a erosão. Vale conferir precioso estudo de Filomena Martins e Henrique Albuquerque, Gestão do litoral e política pública em Portugal: um diagnóstico. Departamento de Ambiente e Ordenamento da Universidade de Aveiro CESAM, 1998.

71 Estratégia essa que deverá compreender: "Sustentabilidade e solidariedade intergeracional, promovendo a compatibilização em todo o território nacional entre o desenvolvimento socioeconômico, a conservação da natureza e da biodiversidade, num quadro de qualidade de vida das populações atuais e vindouras; Coesão e equidade social, assegurando o equilíbrio social e territorial e uma distribuição equilibrada dos recursos e das oportunidades, pelos diversos grupos sociais, classes geracionais, territórios e lugares; Prevenção e precaução, prevendo e antecipando os problemas e adaptando uma atitude cautelar face ao déficit de conhecimento ou à capacidade de intervenção, minimizando riscos ou impactos negativos; Abordagem sistêmica, criando uma nova cultura de abordagem transversal, intersectorial, interdisciplinar, que permita uma visão integradora e prospectiva da zona costeira; Suporte científico e técnico, apoiando as decisões de medidas de ordenamento e gestão na compreensão dos fenômenos e na sua evolução dinâmica; Subsidiariedade, coordenando os 
No âmbito supranacional, a Comissão Europeia vem buscando um modelo próprio que se adapte a diferentes realidades políticas, econômicas e jurídicas dos Estados membros. Não obstante numerosas tentativas, entre as quais se destacam a Carta Europeia do Litoral Conferência de Regiões Marítimas Periféricas da Europa - 1981, não se encontrou uma fórmula que aglutinasse interesses tão distintos e contribuísse para a solução dos graves problemas dos recursos costeiros europeus.

O último projeto nesse sentido foi o Programa de Demonstração sobre Gestão Integrada de Zonas Costeiras (1997-1999), cujas conclusões foram baseadas na observação da realidade de 35 regiões costeiras europeias (European Comission, 1999). Alguns documentos internos assinalam a necessidade e as possibilidades de atuação por parte das instituições europeias (Comissão Europeia, 1995, 1997, 1999, a, b). O Conselho da Europa também tem demonstrado interesse na melhoria da gestão das áreas litorâneas: o desenho de modelos normativos que inspirem os Estados membros e a redação de um Código de Conduta são as abordagens mais recentes (Council of Europe, $2000 \mathrm{a}, \mathrm{b}) .^{72}$

procedimentos dos diversos níveis da Administração Pública, de forma a privilegiar o nível decisório mais próximo do cidadão; Participação, potenciando o activo envolvimento do público, das instituições e agentes locais e reforçando a consciência cívica dos cidadãos através do acesso à informação e à intervenção nos procedimentos de elaboração, execução, avaliação e revisão dos instrumentos de gestão territorial; Corresponsabilização, assumindo a partilha da responsabilidade nas ações de gestão da zona costeira com a comunidade, os agentes econômicos, os cidadãos e associações representativas, não só pelo princípio do poluidor-pagador e do utilizador-pagador, mas também, pela procura de formas institucionais que permitam uma gestão mais próxima dos cidadãos e dos utentes da zona costeira; Operacionalidade, criando mecanismos legais, institucionais, financeiros e programáticos céleres, eficazes e com fontes de financiamento próprias, capazes de garantir a realização dos objetivos e das intervenções". Idem, p. 338-339.

72 Idem, p. 141. 
Portanto, a gestão eficiente da orla marítima constitui destacada preocupação de países com significativa parcela da atividade econômica desenvolvida na zona costeira. No caso brasileiro, o Projeto Orla emerge como relevante instrumento realização desse propósito, especialmente nos Municípios menos desenvolvidos, desprovidos de recursos humanos e econômicos.

\subsubsection{Terreno de marinha e acrescidos}

a) fundamentos e histórico dos institutos

Malgrado a necessidade de tratamento da zona costeira como uma totalidade geográfica, social e econômica e consequente disciplina legal unitária, o direito brasileiro persiste na manutenção do instituto do terreno de marinha, proporcionando uma sobreposição de competências (dominial da União com atividades dos Municípios) que representa entrave ao desenvolvimento da região. ${ }^{73}$

Ressalta-se, uma vez mais, que o presente estudo não inclui o espaço territorial situado fora do perímetro urbano, bem como os terrenos marginais de rios na mesma situação, ainda que em foz estuarina.

73 Cf. infra 2.4. 
ANTONIO CHAVES aponta dois fatores que explicam o tratamento diferenciado emprestado à fronteira marítima e terrestre, um de ordem histórica, pois a orla marítima foi a primeira região do território nacional a se desenvolver, especialmente na cidade do Rio de Janeiro no século XVII, e outro de cunho estratégico, pois a possibilidade de invasão por parte de um inimigo pode ser prevenida de forma mais eficiente na borda litorânea. ${ }^{74}$

$\mathrm{O}$ argumento de defesa nacional constitui o mais antigo fundamento, sendo ainda o mais invocado, para manutenção dos terrenos de marinha na esfera de competência da União ${ }^{75}$. Em tempos menos antigos, a preocupação com um tratamento unitário da proteção ambiental, bem como a disciplina do uso e ocupação do solo urbano, passou a compor a tríplice justificativa da manutenção do instituto em comento.

ANTONIO CHAVES ${ }^{76}$ lembra ainda que os romanos permitiam o uso das praias e do mar a todos os interessados. Eram coisas comuns e sobre elas qualquer um podia erguer cabanas para abrigo e até construir casas, tornando-se os donos das casas, senhores do solo enquanto subsistiam as construções, como uma espécie de domínio resolúvel, de modo que, destruída a casa, desapareceria o direito sobre o solo.

74 Praias, ilhas e terrenos de marinha, Revista Trimestral de Jurisprudência dos Estados, 109/9-10, fev/93.

75 O imperativo de segurança nacional também é referido em outros sistemas jurídicos, como no direito norte americano, não apenas para conter invasão de eventual inimigo mas também para coibir atividades ilícitas como o contrabando, o tráfico de armas e drogas e a imigração ilegal conforme John R. Clark (Coastal zone management, p. 15).

76 Cit., p. 10. 
JUAN MANUEL BARRAGÁN MUÑOZ também recorda a origem romanística do instituto e explica sua permanência em muitos sistemas latino americanos, herdeiros da tradição do direito romano, não obstante recebam denominações diferentes: Bens de Domínio Público (Argentina), Bens da União (Brasil), Bens de Uso Público (Colombia), Bem Nacional de Uso Público (Chile), Zona Federal Marítimo Terrestre (México). ${ }^{77}$

Ao tratar da inalienabilidade como elemento característico dos bens públicos, JACQUELINE MORAND-DEVILLER ${ }^{78}$ observa que a manutenção do bem na esfera pública com o intuito de evitar sua dilapidação já se encontrava sob o Antigo Regime como lei fundamental do reino, sujeitando-o ao 'Domínio da Coroa', e, posteriormente a 1789, ao ‘Domínio da Nação'.

Resta indagar a utilidade de manutenção sob o domínio público dos referidos terrenos, porquanto representar desnecessário entrave à sua adequada e produtiva utilização, pois assegurar a utilização de tais bens afetados ao interesse geral - leia-se função social - não exige, necessariamente, a sua direta utilização pelo poder público.

A importância do instituto do terreno de marinha e acrescidos, no âmbito deste trabalho, justifica o breve histórico do seu regramento jurídico no direito brasileiro. ${ }^{79}$

77 La gestión de áreas litorales en España y Latinoamérica, Universidad de Cádiz, 2005, p. 28. 78 Cours de droit administratif des biens, 3 ed. Paris, Montchrestien, 2003, p. 13-15.

79 Conferir trabalho sobre o histórico dos institutos: Levi Carneiro, Terras devolutas, Terrenos de marinha. Revista de Direito Administrativo, Rio de Janeiro, FGV, vol. 4, abr./1946, p. 356-357. 
No período colonial brasileiro havia um imperativo estratégico da Coroa em ter sob seu domínio as terras contíguas ao mar, pois, nos Séculos XVI e XVII, vários países europeus se recusaram a aceitar os termos do Tratado de Tordesilhas e somente a faixa costeira era povoada e sujeita aos ataques de piratas e corsários. ${ }^{80}$

Com a vinda da família real ao Brasil, momento em que a administração pública ganhou forte impulso, é que surgiu o primeiro decreto, expedido em 21.01.1809, onde se tratava dos terrenos de marinha.

Durante o Império houve significativa alteração no trato do instituto, pois a Lei de 15.11.1831 (art. 15, § 14) colocou à disposição das Câmaras Municipais os térreos de marinha que estas reclamarem do Ministério da Fazenda, ou dos Presidentes das Províncias para logradouros públicos. ${ }^{81}$

80 A Ordenação Filipina não se referiu de modo expresso a terrenos de marinha, mas, sim, a portos de mar (Ord. L.2, XXVI, § 9), e a rendas que antigamente costumaram levar das Marinhas, em que se faz o sal no mar, ou em qualquer outra parte (idem, $\S 15)$. As leis posteriores mantiveram esse postulado, ao vedar aos particulares a apropriação das praias do mar, como demonstra as Ordens Régias através das quais a Coroa Portuguesa procurou impedir os avanços das construções e aterros sobre as praias do Rio de Janeiro (de 01.11.1726 e 21.10.1710 e 05.05.1726). A Ordem Régia de 10.01.1732 garantiu aos pescadores o acesso ao mar e enunciou o princípio segundo o qual as praias pertencem ao domínio público marítimo, sendo inapropriáveis.

81 A normatização do período manteve os terrenos de marinha na esfera municipal: a Portaria ํㅜ 348 , de 14.11.1832, dividiu os terrenos de marinha localizados na cidade do Rio de Janeiro em três classes, contemplando na primeira os que devem ser reservados para logradouros públicos (art. 1ํ), prevendo ainda várias formalidades objetivando a satisfação dos interesses locais (art. 2ำ, 5ํ e 6ㅇ); a Lei Imperial ํㅡ 38, de 03.10.1834, art. 37, § 2 \&, transferiu à Câmara Municipal do Rio de Janeiro o direito de arrecadar foros dos terrenos de marinha compreendidos no seu município; e a Lei no 3.348 , de 20.10.1887, art. $8^{\circ}, \S 3^{\circ}$, autorizou a transferência para as municipalidades de todo o País, dos direitos de aforar e cobrar foros e laudêmios; o Dec. o 4.105, de 22.12 .1868 considerou em seu art. 1으, § 1으, terrenos de marinha todos os que, banhados pelas águas do mar ou dos rios navegáveis, vão até à 
Com o advento da República, o Dec. Legislativo n 25, de 30.12.1891, retirou das Câmaras

Municipais a faculdade de aforar aludidos imóveis, reassumindo a União essa atribuição, sendo que as marinhas situadas na cidade do Rio de Janeiro só reverteram muito mais tarde, pelo Decreto-lei $\mathrm{n}^{\mathrm{o}} 710$, de 17.09.1938, art. $1^{\circ}, d$.

Após sucessivos decretos, ${ }^{82}$ o Dec.-lei n ${ }^{\circ}$ 9.760, de 05.09.1946, ao dispor sobre os imóveis da União, tratou do terreno de marinha, conferindo-lhe o regramento vigente ${ }^{83}$, recepcionado pelo art. 20, VII da Carta de 1988 e $49, \S 3^{\circ}$ do ADCT. ${ }^{84}$

distância de 15 braças craveiras (33 m) para a parte da terra, contadas desde o ponto a que chega a preamar médio. Pelo art. 3: As Câmaras Municipais, logo que forem apresentados os requerimentos, examiná-los-ão, especialmente sob o ponto de vista do alinhamento e regularidade dos cais e edificações, da servidão e logradouros públicos, ou de interesses municipais, informando circunstanciadamente a tal respeito ao Ministério da Fazenda na Corte e aos Presidentes nas Províncias, e emitindo a sua opinião sobre a possibilidade e vantagens da concessão.

82 O Decreto № 14.595, de 31.12.1920, estabeleceu a cobrança da taxa de ocupação de terreno de marinha; $\mathrm{o}$ art. 13 do Código de Águas (Dec. ํㅡ 24.643, de 10.07.1934), manteve o princípio, definido como terrenos de marinha os que, banhados pelas águas do mar ou dos rios navegáveis, em sua foz, vão até $33 \mathrm{~m}$. para a parte da terra, contados desde o ponto a que chegava o preamar médio em 1831, distância correspondentes a 15 braças craveiras (medida anterior à adoção do sistema métrico decimal) na data da execução da Lei 11.11.1831; o Dec.-lei no 2.490, de 16.08.1940, acrescentou as lagoas, fez referência até onde chega a influência das marés, que, de acordo com o art. $2^{\circ}, \S 20$ e art. $3^{\circ}$, caracteriza-se pela oscilação diária do nível das águas. Outra inovação foi a restrição do regime de aforamento aos brasileiros natos ou naturalizados (caput do art. 2o), justificável em razão do momento histórico vivido; o art. 1ํ do Dec.-lei no 3.438, de 17.07.1941, amplia essa classificação e define como terrenos de marinha os que, numa profundidade de $33 \mathrm{~m}$, medidos para a parte da terra, do ponto em que passava a linda da preamar médio em 1831, estão situados no continente, na costa marítima e nas margens dos rios e lagoas, até onde se faça sentir a influência das marés e os que contornam as linhas situadas em zonas onde se façam sentir a mencionada influência. Para efeitos deste artigo, a influência das marés é caracterizada pela oscilação de $5 \mathrm{~cm}$, pelo menos, do nível das águas (atração luni-solar) que ocorra em qualquer época do ano; o Dec.-lei no 4.120 , de 21.02.1942, em seu art. 3ํㅡ, dispôs que a origem da faixa dos $33 \mathrm{~m}$. de terrenos da marinha não seria mais a linha da preamar médio de 1831 , mas sim a linha da preamar máximo atual.

83 Art. $2^{\circ}$. São terrenos de marinha em uma profundidade de $33 \mathrm{~m}$., medidos horizontalmente, para a parte da terra, na posição da preamar médio de 1831: a) Os situados no continente, na costa marítima e nas margens dos rios e lagoas, até onde se faça sentir a influência das marés; b) Os que contornam as linhas situadas em zona onde se faca sentir a influência das marés. Vale salientar que mesmo após o Decreto-lei no 9.760, de 05.09.1946, o instituto continuou sendo objeto de normatização: o Decreto-lei 
b) Delimitação da faixa de marinha e terrenos acrescidos

Terreno de marinha não se confunde com praia $^{85}$, pois é possível que a praia supere o limite de 33 metros ou, ao contrário, a linha d'água encontre a porção terrestre em paredão rochoso ou escarpa.

Para a doutrina, “A praia é uma região litorânea, contígua ao mar, cujas características físicas permitem o acesso ao mar e a sua fruição pelos indivíduos, inclusive para fins de lazer. Já o terreno de marinha é aquela área que se encontra a uma distância determinada da preamar média de 15.11.1831. Logo, é perfeitamente possível que a praia ultrapasse a extensão do terreno de marinha, basta a região litorânea superar a extensão de 33 metros. Por outro lado,

oㅜ 1.561, de 13.07.1977, dispôs sobre a ocupação gratuita de terrenos da União; o Dec.-lei oํ 1.876, de 15.07.1981, previu a dispensa de pagamento de foros e laudêmios para os Estados e Municípios, bem como para pessoas consideradas carentes ou de baixa renda, cuja situação econômica não thes permita pagar esses encargos sem prejuízo do sustento próprio ou de sua família (redação dada pela Lei no 11.481, de 31.05.2007); o Dec.-lei no 2.398, de 21.12.1987, sobre foros, laudêmios e taxas de ocupação, relativos a imóveis de propriedade da União; a Lei ํo 9.636, de 15.02.1998, com alterações pela Lei $n^{\circ}$ 11.481, de 31.05.2007, ao disciplinar a regularização, administração, aforamento e alienação de bens imóveis de domínio da União, alterou dispositivos dos Decretos-leis nos 9.760 , de 05.09.1946 e 2.398, de 21.12.1987, e regulamentou o § $2^{\circ}$ do art. 49 do ADCT.

84 A Constituição Federal de 1988 manteve o instituto no art. 20, VII, são bens da União (...) os terrenos de marinha e seus acrescidos; mantida a aplicação do instituto da enfiteuse pelo art. 49 , $\S 3^{\circ}$ do ADCT: a enfiteuse continuará sendo aplicada aos terrenos de marinha e seus acrescidos, situados na faixa de segurança, a partir da orla marítima.

85 Infra 3.2. 
há situações em que não existe praia em sentido próprio, pois o terreno é coberto por pedras que tornam inadequadas a sua utilização pelos indivíduos". 86

A dificuldade da exata identificação da preamar médio do distante ano de 1831, induz à problemática insolúvel da delimitação da faixa de marinha, vez que as suas características físicas dependem das peculiaridades da costa considerada, variando, entre outros fatores, da inclinação e da superfície do terreno, não se olvidando que a dinâmica dos ambientes costeiros faz com que a linha de preamar média mude, a cada dia, em alguns locais. Portanto, podem ser fixadas não apenas em um ponto situado em uma praia plana, mas também em meio a dunas, falésias, costões rochosos ou manguezais.

Estudo de CARLOS ROBERTO SOARES e RODOLFO JOSÉ ÂNGULO ${ }^{87}$, debruçado sobre a delimitação da linha da preamar medida de 1831, define marés como fenômenos de oscilação do nível do mar, tratando-se de ondas de grande período (6 a 12 horas) que afetam a superfície do mar, diferenciando as marés astronômicas das meteorológicas. As primeiras, originada pela interação entre os campos gravitacionais do sistema Terra-Lua-Sol, são passíveis de precisão e previsíveis para cada local da terra, cujas maiores amplitudes são atingidas nos períodos de lua cheia e nova (marés de sizígia), e as menores nas luas crescente e minguante (marés de quadratura) ${ }^{88}$. As últimas não podem ser previstas e decorrem de fenômenos meteorológicos como ventos, ondas correntes costeiras e pressão atmosférica,

86 Marçal Justen Filho, Curso de Direito Administrativo, 9 ed., São Paulo, Revista dos Tribunais, 2013, p. 1165-1166.

87 Sobre a delimitação da linha de preamar média de 1831, que define os terrenos de marinha, Revista de Direito Ambiental, vol. 20, São Paulo, Revista dos Tribunais, out.-dez. 2000, p. 263.

88 A Diretoria de Hidrografia e Navegação da Marinha publica as Tábuas de Marés para os principais portos brasileiros. 
podendo coincidir com as marés astronômicas, provocando fenômenos conhecidos como 'ressacas', que podem provocar o recuo da linha de $\operatorname{costa}^{89}$ proporcionando perda de áreas continentais (erosão ou praial) ou o seu avanço (progradação).

Os autores explicam ainda que o nível da preamar média é uma altitude, isto é, a distância vertical entre um nível zero de referência e a altura da preamar média num determinado local e período. A mencionada linha resulta da intersecção de um plano horizontal com a superfície do terreno, podendo ser determinada através da transferência de cotas com níveis de precisão e com teodolitos, desde que haja na região um marco de referência de primeira ordem, devidamente cadastrado no IBGE. As informações sobre o nível da preamar média provêm de marégrafos na costa brasileira, em regra instalados em áreas protegidas (estuários), onde há atividade portuária, que também devem estar referenciados a um marco.

Além disso, demonstram a impossibilidade de se definir o nível da preamar média de 1831.

Para tal, deveria ser encontrado um registro maregráfico desse ano, além da necessidade desta informação estar associada a um marco ou nível de referência. Entretanto, esse registro parece não existir para a costa brasileira ${ }^{90}$. Uma possibilidade, para se obter um dado aproximado

89 Limite entre a costa e o litoral, cuja materialização espacial se dá através da presença de falésias (barrancos ou combros), no limite entre as dunas vegetadas e a praia, no limite máximo atingido pelas ondas nos costões rochosos, ou em qualquer outra feição geomorfológica que indique o limite máximo atingido pela ação do mar ou outro corpo d'água, que separe a costa do litoral.

90 Para a demarcação dos terrenos de marinha, o art. 10 do Dec.-lei no 9.760, de 05.09.1946, determina a utilização de plantas de autenticidade irrecusável relativas àquele ano, ou, quando não obtidas, à época que do mesmo se aproxime. Os autores observam que no caso da Baía de Paranaguá, mapas antigos com datas mais próximas de 1831 podem ser encontrados em Soares \& Lana (1994). Todavia, mesmo que nesses mapas estivesse delimitada a linha de preamar, a pequena escala, geralmente em torno de 1:250.000, não permite demarcar os $33 \mathrm{~m}$, o que corresponderia na prática, em termos cartográficos, a aproximadamente $0,13 \mathrm{~mm}$. 
seria, da mesma forma que se faz uma previsão astronômica de maré para qualquer local situado na costa, calcular a altura da preamar média astronômica de 1831. Porém, permaneceria o problema da localização, pois não há menção no decreto-lei a um local ou a um nível qualquer de referência. ${ }^{91}$

Hoje, não se concebe um processo de delimitação da linha de costa sem a utilização de instrumentos tecnológicos de precisão, como o Sistema de Posicionamento Global (GPS) e imagens de satélites.

Nesse trilhar, em artigo resultante de criteriosa pesquisa com o intuito de situar, no tempo e no espaço geográfico, a linha da preamar média de 1831, OBÉDE PEREIRA DE LIMA e JÜRGEN WILHELM PHILIPS ${ }^{92}$ acreditam ter encontrado a localização geodésica real, propondo sua adoção pelas empresas que realizam serviços geodésicos, topográficos, hidrográficos e cartográficos cadastrais, e pelo Poder Judiciário como paradigma nas perícias destinadas à instrução das ações propostas sobre a matéria. Ademais, recomendam que a Secretaria de Patrimônio da União (SPU) modifique os critérios e procedimentos na localização da linha da preamar média de 1831 até então utilizados, bem como reveja todos os processos demarcatórios dos terrenos de marinha e seus acrescidos, refazendo todo o mapeamento cadastral destas parcelas imobiliárias pela metodologia desenvolvida naquela tese, restituindo aos legítimos proprietários, ex officio, todas as propriedades privadas que foram afetadas pelas demarcações passadas.

91 Soares e Ângulo, cit., p. 264.

92 Demarcação dos terrenos de marinha e seus acrescidos, Revista de Direito Imobiliário, ํㅜ 59, São Paulo, Revista dos Tribunais, jul.-dez. 2005, p. 166-193. 
Conforme sustentado, a precariedade dos critérios de delimitação da linha de costa constitui expressivo argumento em favor de um tratamento que abarque a totalidade da zona costeira e não apenas esta estreita faixa.

De qualquer forma, eventual correção científica do trabalho mencionado ${ }^{93}$, não justifica a manutenção do instituto em testilha, mormente considerada a insegurança jurídica que modificação dos critérios até então utilizados traria em prol de duvidoso proveito.

JACQUELINE MORAND-DEVILLER explica que, atualmente, no direito francês, os limites foram definidos pelo Conselho de Estado no caso Kreitmann, de 12.10.1973, que modernizou e unificou os critérios de delimitação da borda mediterrânea com as outras orlas, submetendo o litoral francês a um regime único, fixado no limite máximo atingido pelo mar na ausência de perturbações meteorológicas excepcionais. ${ }^{94}$

A par dos terrenos de marinha, cumpre ainda aludir aos terrenos acrescidos de marinha ${ }^{95}$ como aqueles formados, por fato natural ou artificial, para o lado do mar ou dos rios e lagoas,

93 Cuja contestação científica foge ao propósito, e alcance científico, deste trabalho.

94 Cours de droit administratif des biens, p. 43-44.

95 Decreto no 4.105, de 22.02.1868, art. 1오 $\S 3^{\circ}$, declaravam serem terrenos acrescidos de marinha "todos os que natural ou artificialmente se tiverem formado ou formarem além do ponto determinado nos $\S \S 1^{\circ}$ e $2^{\circ}$, para parte do mar ou das águas dos rios (Resolução do Conselho de 31.01 .1852 e Lei ํㅜ 1.114, de 27.09.1860, art. $11, \S 7^{\circ}$ ). 
em seguimento aos terrenos de marinha (art. $3^{\circ}$ do Dec.-lei $n^{\circ} 9.760$, de 05.09.1947), por aluvião, avulsão, ou ainda álveo descoberto pelo afastamento das águas.

Havia polêmica na vigência do Código Civil de 1916, vez que o art. $538^{96}$ determinava que os terrenos acrescidos por aluvião pertenciam ao proprietário do terreno marginal, enquanto o art. 16, § $1^{\circ}$, do Código de Águas (Decreto $\mathrm{n}^{\circ} 24.643$, de 10.07.1934), posterior, determinava serem estes bens públicos dominicais, resultando antinomia aparente, vez que este apenas se referia a bem público formado por aluvião caso não estivesse destinado ao uso comum, ou se por algum título legítimo não fosse de domínio particular. ${ }^{97}$

Ainda que desapareçam os fenômenos naturais e físicos que justificaram a sua incorporação ao domínio público, mantém o bem tal classificação enquanto pendente ato formal de desclassificação.

Os aterros do fundo do $\operatorname{mar}^{98}$, em regra proibidos, estarão condicionados à anuência do Ministério da Marinha, dependendo sua execução de licença concedida através de ato legislativo específico.

96 Art. 538. Os acréscimos formados por depósitos e aterros naturais, ou pelo desvio das águas dos rios, ainda que estes sejam navegáveis, pertencem aos donos dos terrenos marginais.

97 Floriano de Azevedo Marques Neto, O regime jurídico das utilidades públicas - função social e exploração econômica dos bens públicos - Tese de Livre-Docência - USP, 2008, p. 165.

98 Decreto ํㅜ 4.105, de 22.02.1868 e Circular do Ministério da Marinha № 24/66. 
A afetação de tais terrenos ante o avanço das técnicas de engenharia, a exemplo do ocorrido na orla da cidade do Rio de Janeiro e que descaracteriza a natureza jurídica de bem dominical, merece atento olhar de FLORIANO DE AZEVEDO MARQUES NETO: “A doutrina entende que estes terrenos seguem o mesmo regime dos terrenos de marinha, sendo, pois, dominicais. Ocorre que, com o avanço das técnicas de engenharia, novos usos passaram a ensejar ganhos territoriais sobre o mar, com vistas ao emprego de tais áreas em finalidades como instalações portuárias e aeroportuárias (caso do aeroporto Santos Dumont), ou mesmo para implantação de infraestruturas de serviços públicos (como os emboques de emissários submarinos de esgotos). Segue daí nosso entendimento de que muitos terrenos artificialmente acrescidos não são bens dominicais pelo simples fato de que a razão de terem sido implantados (ou seja, a finalidade pela qual artificialmente se adentrou um aterro sobre o mar) leva a que eles tenham uma afetação para o uso comum ou para o uso especial, ao menos até que haja a corespondente desafetação. Por força da Constituição, tal situação pode ensejar a existência de bens da União afetados a usos materialmente de competência de outros entes da Federação (como as vias urbanas ou os bens afetados à prestação de serviços públicos estaduais)". 99

O direito espanhol também confere tratamento especial aos terrenos acrescidos com vistas a frear o processo de privatização do litoral, do qual decorreu notável degradação ambiental de sua costa, atingida por expressiva onda de especulação imobiliária decorrente do crescimento do turismo, ao coibir a sua apropriação privada (bem como a perda em favor do Estado

99 O regime jurídico das utilidades públicas, p. 166-167. 
daqueles perdidos ao mar), limitando-se a expectativa de se obter a propriedade de um solo ainda não existente. ${ }^{100}$

Destarte, a delimitação dos terrenos situados na borda litorânea possui relevância jurídica, no caso brasileiro dando origem aos denominados terrenos de marinha e acrescidos. Todavia, o desenvolvimento econômico, a valorização imobiliária da região costeira e o surgimento de novas técnicas de engenharia são fatores que justificam a defesa da alteração de seu vetusto regime jurídico, conforme será visto no curso deste trabalho.

\subsection{3. - Aforamento e ocupação}

Os terrenos de marinha e acrescidos são bens dominicais ou de uso comum do povo, que podem ser explorados pela Administração Pública ou ter o uso concedido ao particular, pelo regime de aforamento $^{101}$ ou ocupação ${ }^{102}$, mediante a transferência do domínio útil e

100 Conforme demonstra Juan Jesús Trapero: os terrenos ganhados ao mar, como consequência direta ou indireta de obras realizadas em sua orla, pertencem ao domínio público marítimo-terrestre estatal (art. 4.2) e em nenhum caso o particular adquirirá sua propriedade, ressalvados os direitos dos atuais proprietários. Com essas disposições se põe um limite a um processo de privatização do litoral, seguido de uma especulação degradante da costa, impedindo que tais terrenos possam, no futuro, a se tornar propriedade particular (Aspectos urbanísticos de la proteción del territorio litoral, p. 57).

101 Lei ํㅜ 9.636, de 15.05.1998, art. 12 a 16.

102 Lei oㅜ 9.636, de 15.05.1998, art. 7ํㅡ a 10. 
pagamento de rendimento denominado foro ou pensão ${ }^{103}$ (no caso do aforamento), mantendo a União o domínio direto dos terrenos.

Os mencionados bens não podem ser usados indistintamente pelos administrados, e seu uso, quando consentido e sendo exclusivo, precário, compatível com o interesse público e de acordo com as condições fixadas pela Administração, deve ser remunerado.

A respeito da natureza jurídica dos terrenos de marinha, MARÇAL JUSTEN FILHO lembra: “costuma-se qualificá-los como dominicais, mas é necessário verificar se a mesma área não se configura como bem público de outra qualidade. Assim, por exemplo, o próprio art. 20, IV, da Constituição Federal, também qualifica como bem público as praias marítimas, que usualmente preenchem os requisitos para o enquadramento como terreno de marinha. Mas as praias são, usualmente, bens de uso comum do povo". ${ }^{104}$

Para ODETE MEDAUAR ${ }^{105}$, “A utilização privativa, por particulares, dos terrenos de marinha se efetua mediante enfiteuse ou aforamento, como ocorre com casas ou prédios de apartamentos na orla marítima, dentro do limite de uma linha de profundidade de 33 metros,

$103 \mathrm{O}$ art. 101 do Decreto-lei oㅜ 9.760 prevê o pagamento anual de uma importância chamada foro, no valor de $0,6 \%$ do valor do respectivo domínio pleno, anualmente atualizado, importando a caducidade do aforamento o não pagamento por três anos consecutivos ou quatro intercalados, admitida a revigoração com o pagamento dos foros em atraso (art. 118 e 119). Sujeitar-se-á ao pagamento do laudêmio, no valor de $5 \%$ do valor atualizado do domínio pleno e das benfeitorias (Decreto-lei $\mathrm{n}^{\circ}$ 2.398/1987), a transferência onerosa, por ato inter vivos, do domínio útil ou de direitos sobre as benfeitorias, bem como a cessão de direitos a ele relativo.

104 Curso de direito administrativo, p. 1165.

105 Direito administrativo moderno, p. 288. 
medidos horizontalmente, para a parte da terra, da posição da linha do preamar médio de 1831 (como estava a linha na época da execução do $\S 4^{\circ}$ do art. 15 da lei datada de 15.11.1831)”.

A utilização do terreno de marinha por particular se dava, inicialmente, pelo regime de aforamento, instrumento que mantém direito real da União sobre tais bens, ao tempo em que permite ao particular (foreiro ou enfiteuta) seu uso, gozo e mesmo disposição do direito, mediante o pagamento perpétuo de um foro ao senhorio direto, no caso a União.

A enfiteuse, banida do direito civil, permaneceu em relação aos terrenos de marinha, situados na faixa de segurança a partir da orla marítima, seja por expressa previsão constitucional ${ }^{106}$ ou infraconstitucional, ${ }^{107}$ não obstante a possibilidade de sua extinção em imóveis urbanos, com a remição dos aforamentos e consequente aquisição do domínio direto pelos foreiros.

O regime pautou-se, em linhas gerais, pelo regime do art. 678 do Código Civil de $1916 .{ }^{108} \mathrm{O}$ art. 694 do mesmo Estatuto remetia à lei especial a regulamentação da enfiteuse dos terrenos de marinha e seus acrescidos, o que se deu com a edição do Decreto-lei $\mathrm{n}^{\circ}$ 9.760, de

106 ADCT, art. 49, §3ํ: enfiteuse continuará sendo aplicada aos terrenos de marinha e seus acrescidos, situados na faixa de segurança, a partir da orla marítima (recentemente modificado pela Lei no 11.481, de 31.05.2007).

107 Código Civil, art. 2.038, $\S 2 \stackrel{\circ}{\text { : }}$ a enfiteuse dos terrenos de marinha e acrescida regula-se por lei especial.

108 Art. 678. Dá-se a enfiteuse, aforamento ou emprazamento, quando por ato entre vivos, ou de última vontade, o proprietário atribui a outro o domínio útil do imóvel, pagando a pessoa que o adquire e assim se constitui enfiteuta, ao senhorio direto uma pensão, ou foro, anual, certo e invariável. 
05.09.1946, art. 99 a 126, estatuindo restrições inexistentes no direito civil, como autorização do Presidente da República (dispensada caso existente permissão expressa em lei), atendimento ao interesse público, manifestação da SPU na hipótese de transferência ou da satisfação de eventuais exigências formuladas. Ademais, a remição, que no direito civil é um direito irrenunciável do foreiro ou enfiteuta, no direito público depende de autorização do Presidente da República, mediante proposta do Ministro da Fazenda e facultado nas zonas onde não mais subsistem os motivos determinantes da aplicação do regime enfitêutico.

Lembra ANTONIO CHAVES ${ }^{109}$ : "o aforamento caberá quando concorrerem tanto a conveniência de radicar-se o indivíduo ao solo, como a de manter-se o vínculo de propriedade pública, mas a concessão fica subordinada à prévia consulta de órgãos militares ou administrativos, ou às Prefeituras Municipais. Aqueles serão ouvidos relativamente aos interesses que a área encerra para a segurança nacional ou para seu aproveitamento agrícola ou pastoril, ou proximidade a obras portuárias, rodoviárias, de saneamento ou irrigação. Já as Municipalidades devem manifestar-se quando a concessão envolva zona que está sendo urbanizada".

A par do aforamento dos mencionados terrenos, o Decreto $\mathrm{n}^{\circ}$ 14.595, de 31.12.1920, conforme autorização concedida pela Lei 3.979, de 31.12.1919, art. $2^{\circ}, \mathrm{n}^{\mathrm{o}} \mathrm{V}$, criou a 'taxa' de ocupação, passível de atualização periódica e financeiramente mais interessante do que o foro, que é de natureza fixa e pouco rentável.

109 Cit., p. 15-16. 
Trata-se de estado de mera tolerância, ato precário, discricionário e unilateral, estado de fato que a União reconhece como capaz de gerar direito de preferência ao aforamento do terreno ocupado, cuja disciplina atual é dada pela Lei $\mathrm{n}^{\mathrm{o}} 11.481$, de $31.05 .2007^{110}$ e pelos art. $7^{\circ}$ a 10 da Lei $\mathrm{n}^{\circ}$ 9.636, de 15.05.1998, que alterou parcialmente os art. 127 a 133 do Decreto-lei $\mathrm{n}^{\circ}$ 9.760, de 05.09.1946.

A 'taxa' de ocupação, disciplinada pelo Decreto-lei nº 2.398, de 21.12.1987, é suscetível de atualização monetária $^{111}$ e paga anualmente, a porcentagem de $2 \%$ para as ocupações cuja inscrição tenha sido requerida até 30.09.1988, calculada sobre o valor do domínio pleno do terreno; e 5\% para as ocupações cuja inscrição tenha sido requerida ou promovida ex officio, a partir de 01.10 .1988 , pressupondo o efetivo aproveitamento do terreno. ${ }^{112}$

Não obstante a usual denominação de 'taxa', não tem natureza tributária ${ }^{113}$, pois é receita patrimonial decorrente de utilização de um bem de propriedade da União por um terceiro. Ademais, na ocupação não existe o desmembramento da propriedade, mantendo a União o domínio pleno sobre os imóveis ocupados.

110 Esta lei instituiu a inscrição da ocupação, referida anteriormente no art. 7ำ a Lei no 9.636, de 15.05.1998, cuja redação é a que segue: A inscrição de ocupação, a cargo da Secretaria de Patrimônio da União, é ato administrativo precário, resolúvel a qualquer tempo, que pressupõe o efetivo aproveitamento do terreno pelo ocupante, nos termos do regulamento, outorgada pela administração depois de analisada a conveniência e oportunidade, e gera obrigação de pagamento anual da taxa de ocupação.

111 Há divergência quanto à necessidade de intimação do ocupante para ciência da referida atualização, por suposta afronta ao contraditório previsto na Lei no 9.784, de 29.01.1999, que regula o processo administrativo no âmbito da Administração Pública Federal.

112 Isenção da taxa se comprovada carência a cada quatro anos, nos casos de renda familiar igual ou inferior a cinco salários mínimos.

113 Trata-se na verdade de preço público, e não taxa nos moldes do art. 145, II, da Constituição Federal, e art. $39, \S 2^{\circ}$ do CTN, vez que a ocupação não se enquadra em qualquer dos tipos de fatos geradores previstos na Lei Maior, tratando-se de receita patrimonial em virtude da utilização de um bem de propriedade da União, por um terceiro. 
Desta forma, a demonstração do efetivo aproveitamento pelo ocupante e a onerosidade são requisitos para a inscrição da ocupação, não sendo transferível por ato inter vivos, mas por causa mortis, desde que submetido novo pedido à Secretaria de Patrimônio da União e preenchidos os mesmos requisitos pelos sucessores do ocupante. Salienta-se ainda, que o regime prescinde de licitação por ser intuitu personae, porquanto seus destinatários são apenas aqueles que ocupam a área.

Observa JOSÉ DOS SANTOS CARVALHO FILHO ${ }^{114}$ que o direito à cobrança da 'taxa' de ocupação pela União não é perpétuo. "Dispõe a lei que o crédito originado da receita patrimonial se submete à decadência no prazo de dez anos para a constituição do crédito, e à prescrição de cinco anos para sua exigência, contado o prazo a partir do lançamento. Significa, pois, que, ultrapassados tais prazos, fica a Fazenda Federal impedida de cobrar a referida taxa do ocupante do terreno público. Antes da vigência da Lei no 9.636/1998, inexistia legislação específica regulando a matéria, o que gerou divergências quanto ao prazo prescricional para a cobrança da taxa. Prevaleceu, todavia, a interpretação segundo a qual deve aplicar-se o Decreto $n^{\circ}$ 20.910/1932, que fixa em cinco anos a prescrição contra a Fazenda, e não o Código Civil, eis que se trata de matéria de Direito Administrativo, e não de Direito Civil”.

A diferenciação entre a ocupação e a enfiteuse do terreno de marinha também é analisada por MARIA SYLVIA ZANELLA DI PIETRO: "Verifica-se que, na ocupação, não há um ato

114 Manual de direito administrativo, 25 ed., São Paulo, Atlas, 2012, p. 1191. 
prévio de outorga do uso do bem. O particular, por sua própria iniciativa, toma posse do mesmo. Diante dessa situação, a União, com o objetivo de regularizar a ocupação e garantir o recebimento da respectiva taxa, faz a inscrição ex officio ou mediante declaração dos ocupantes, e notifica-os para que requeiram o seu cadastramento. Expirado o prazo da notificação (180 dias), sem que o posseiro tenha providenciado o seu cadastramento, a União imitir-se-á sumariamente na posse do imóvel". ${ }^{115}$

Impende ainda salientar que o art. 22 da Lei $n^{\circ} 9.636$, de 15.05.1998, prevê o repasse ao Município para autorizar a permissão de uso conferida a título precário, para a realização de eventos de curta duração, de natureza recreativa, esportiva, cultural, religiosa ou educacional, desde que as áreas envolvidas lhes sejam cedidas sob regime de cessão de uso na forma do art. 18 da mencionada lei.

Firma-se o entendimento que a contraprestação recebida pela União, a título de enfiteuse ou ocupação, não representa elemento significativo à satisfação do interesse público, tendo em conta os entraves que a manutenção do vetusto instituto do terreno de marinha proporciona ao efetivo desenvolvimento econômico e social da zona costeira urbana, conforme defendido no curso deste trabalho.

115 Uso privativo de bem público por particular, 2 ed., São Paulo, Atlas, 2010, p. 177. 


\section{INTERESSE LOCAL NA ZONA COSTEIRA URBANA}

A Administração local possui a responsabilidade precípua pela disciplina do uso e ocupação do solo, bem como pelo regramento das atividades desenvolvidas da zona costeira urbana, decorrendo de suas decisões, impacto direto e imediato na vida dos cidadãos.

Neste giro, o Plano Nacional de Gerenciamento Costeiro deverá ser efetivado com o fortalecimento do âmbito local, mais apto à obtenção de soluções consensuais e menos intrusivas, construídas em conjunto com os destinatários do ato ${ }^{116}$, por meio da participação do Município no Projeto Orla e pelo manejo dos instrumentos urbanísticos previstos em lei.

\subsection{Competência e evolução histórica do Município}

A identificação do interesse local na zona costeira urbana, representado de forma preponderante pelo Município, deve ser precedida de breve análise do sistema de competências federativas, bem como da compreensão de sua evolução e dimensão histórica.

116 A respeito da responsabilidade primária do poder local, John Vernberg e Winona Vernberg salientam que, historicamente, os governos locais possuem a responsabilidade primária na determinação do uso e manejo dos recursos naturais em suas jurisdições, bem como autoridade sobre o uso do solo e das águas em suas divisas. Suas decisões provocam impacto imediato na vida do cidadão comum (The coastal zone: past, present and future, University of South Carolina Press, 2001, p. 144). 
2.1.1. A competência do município na ordem constitucional vigente

As competências do Estado Federado são repartidas horizontal e verticalmente, a primeira pela atribuição a cada ente federativo de uma área reservada, que lhe cabe disciplinar, e a segunda pela distribuição de uma mesma matéria em diferentes níveis (do geral ao particular). 117

Esclarece TÉRCIO SAMPAIO FERRAZ JÚNIOR que: "No primeiro caso (horizontal), as competências ou são comuns ou são privativas. No segundo (vertical), temos a competência concorrente. Para disciplinar a competência concorrente há duas técnicas conhecidas: a cumulativa, pela qual os entes podem avançar na disciplina das matérias desde que o que lhes é considerado superior não o fala (não há limites prévios, mas a regra da União prevalece, em casos de conflitos); a não cumulativa, em que, previamente, as matérias estão delimitadas por sua extensão (normas gerais e particulares)". ${ }^{118}$

O autor salienta ainda a necessidade de se agregar análise teleológica ao aspecto lógico, pautada pelo contexto finalístico, para identificação da expressão normas gerais: “A expressão

117 Tércio Sampaio Ferraz Júnior define competência como "uma forma de poder jurídico, isto é, de exercício impositivo de comportamentos e relação de autoridade regulada por normas (...). Ao estabelecer essa forma de poder jurídico, a norma de competência enuncia também (ou lhes alude) as condições necessárias para o exercício: as que delimitam qual o sujeito qualificado (competência pessoal), qual o procedimento (competência procedimental) e o alcance possível em face dos sujeitos passivos, sua situação e seu tema (competência material). Fora desses limites, os atos de exercício são nulos e a norma criada por força deles é inválida" (Normas gerais e competência concorrente, Revista Trimestral de Direito Público, no 7, São Paulo, Malheiros, jul.-set. 1994, p. 17-18).

118 Ibidem. 
constitucional - normas gerais - exige também uma hermenêutica teleológica. Sob o mencionado aspecto lógico sempre será possível dizer que, por exemplo, quanto ao conteúdo, normas gerais prescrevem princípios, diretrizes sistemáticas, temas que se referem a uma espécie inteira e não a alguns aspectos, mas isto é insuficiente para reconhecer quando estamos diante de uma norma geral ou de uma particular (...) Deste modo, para o intérprete, a necessidade de se analisar o conteúdo num contexto finalístico se impõe. Assim, do ângulo teleológico, a distinção há de se reportar ao interesse prevalecente na organização federativa."

A competência geral da União está definida no art. 21 do texto constitucional como privativa, e no art. 23 como comum aos Estados, ao Distrito Federal e aos Municípios. A competência legislativa da União, por seu turno, aparece como privativa (art. 22) ou concorrente (art. 24) com os Estados e o Distrito Federal. Nesse caso, cabe à União fixar normas gerais ${ }^{120}$, e aos Estados e Distrito Federal a competência legislativa complementar, ao dispor sobre a matéria segundo as peculiaridades regionais, e competência legislativa supletiva, quando, na inexistência de normas postas pela União, assume a competência legislativa plena (art. $24, \S \S$ $2^{\circ}$ e $\left.3^{\circ}\right)$

119 Idem, p. 18-19.

120 Diogo Figueiredo Moreira Neto aponta as seguintes características das normas gerais: a) estabelecem princípios, diretrizes e linhas mestras e regras jurídicas gerais; b) não podem entrar em pormenores ou detalhes nem, muito menos, esgotar o assunto legislado; c) devem ser regras nacionais, uniformemente aplicáveis a todos os entes públicos; d) devem ser regras uniformes para todas as situações homogêneas; e) só cabem quando preenchem lacunas constitucionais ou disponham sobre áreas de conflito; f) devem referir-se a questões fundamentais; g) são limitadas no sentido de não poderem violar a autonomia dos Estados; h) não são normas de aplicação direta (Competência concorrente limitada: o problema da conceituação das normas gerais. In Revista de Informação Legislativa, v. 100, out.-dez. 1988, p. 149 e ss). 
A propósito da competência concorrente, TÉRCIO SAMPAIO FERRAZ JÚNIOR assevera que a hipótese do art. $24, \S 3^{\circ}$, autoriza o exercício da competência plena aos Estados, com função colmatadora de lacuna apenas na medida necessária para atender às suas peculiaridades. $\mathrm{O} \S 2^{\circ}$ trata da competência suplementar exercida pela da União, também conferida aos Municípios (art. 30, II) que, no entanto, não participam da competência concorrente, e conclui: "Isso nos leva a concluir que a competência suplementar não é para a edição de legislação concorrente, mas para a edição de legislação decorrente, que é uma legislação de regulamentação, portanto de normas gerais que regulam situações já configuradas na legislação federal e às quais não se aplica o disposto no $§ 4^{\circ}$ (ineficácia por superveniência de legislação federal), posto que com elas não concorrem". ${ }^{121}$

Com base nesse raciocínio, na hipótese de inexistência de normas gerais da União ou Estados, há que se concordar com o autor quanto à possibilidade do Município editar normas particulares por meio de outros instrumentos de preenchimento de lacuna (analogia, princípios gerais de direito, costume), e não por intermédio da edição da norma geral ausente (exercício de competência plena com função colmatadora).

$\mathrm{O}$ art. 23, III a VI, da Constituição Federal aponta como competência comum dos entes federados a proteção ambiental (também art. 225, § $1^{\circ}$,I; art. 24, VI a VIII, competência concorrente; art. 30, I e II), cabendo à União o macrozoneamento nos termos do art. 21, IX, que determina ser de sua competência exclusiva elaborar e executar planos nacionais e regionais de ordenação do território e desenvolvimento econômico e social.

121 Idem p. 19-20. 
Aos Estados são reservadas as competências não vedadas pela Constituição (art. $25, \S 1^{\circ}$ ), não existindo vedação expressa para que promova o zoneamento na escala estadual (mesozoneamento), ante o macrozoneamento da União e o microzoneamento do Município.

Ao Município compete suplementar a legislação federal, no que couber, legislar sobre assuntos de interesse local e promover o adequado ordenamento territorial mediante planejamento e controle de uso do parcelamento e da ocupação do solo urbano, ou seja, o microzoneamento (art. 30, I - legislar sobre assuntos de interesse local; II - suplementar a legislação federal e estadual no que couber; VIII - promover, no que couber, adequado ordenamento territorial, mediante planejamento e controle do uso, do parcelamento e da ocupação do solo urbano; e art. 182). ${ }^{122}$

FERNANDA DIAS MENEZES DE ALMEIDA ${ }^{123}$, explica que “o inc. II do art. 30 refere-se não apenas à atividade administrativa regulamentar, mas também à atividade legislativa, podendo os municípios legislar suplementarmente estabelecendo tanto normas específicas como, em sendo o caso, normas gerais, sempre que isso for necessário ao exercício de competências materiais, comuns ou privativas, cabendo a suplementação apenas em relação a assuntos que digam respeito a interesse local. (...) A competência conferida aos Estados para

122 Sobre competência legislativa do Município, verificar Regina Maria Macedo Nery Ferrari, Direito Municipal, 3 ed., São Paulo, Revista dos Tribunais, 2012, p. 95-116. Ver também, a propósito das competências ambientais, Lúcia Valle Figueiredo, Discriminação constitucional das competências ambientais, Revista de Direito Ambiental, n. 35, São Paulo, Revista dos Tribunais, jul.-set. 2004, p. 3955; Heraldo Garcia Vitta, Da divisão de competências das pessoas políticas e o meio ambiente, Revista de Direito Ambiental, n. 10, São Paulo, Revista dos Tribunais, abr.-jun. 1998, pp. 93-101; Paulo Affonso Leme Machado, O município e o direito ambiental. Revista Forense, o 317, Rio de Janeiro, jan.-mar. 1992, p. 189-194

123 Competências na Constituição de 1988, 2 ed., São Paulo, Atlas, p. 157 e ss. 
complementarem as normas gerais da União não exclui a competência do Município de fazêlo também. Mas o Município não poderá contrariar nem as normas gerais da União, o que é óbvio, nem as normas estaduais de complementação, embora possa também detalhar estas últimas, modelando-as mais adequadamente às peculiaridades locais.

Da mesma forma, inexistindo normas gerais da União, ${ }^{124}$ aos Municípios e também aos Estados, abre-se a possibilidade de suprir a lacuna, editando normas gerais para atender às suas peculiaridades. Porém, se o Estado tiver expedido normas gerais, substituindo-as da União, o Município as haverá de respeitar, podendo ainda complementá-las. Não havendo normas gerais supletivas, é livre então o Município para estabelecer as que entender necessárias para o exercício da competência comum. Mas a superveniência de normas gerais, postas pela União diretamente, ou pelos Estados supletivamente, importará a suspensão da eficácia das normas municipais colidentes”.

Para o escopo específico desta tese, distingue-se a competência dominial da União, decorrente da titularidade dos terrenos de marinha, daquela conferida precipuamente ao Município para a disciplina das atividades desenvolvidas na zona costeira (exceção feita à navegação e

124 Pelo art. 24, a União limitar-se-á a estabelecer normas gerais e aos Estados a legislação suplementar respectiva (art. 24, I, VI, VII e VIII), notando-se ainda que, inexistindo lei federal sobre normas gerais, os Estados exercerão a competência legislativa plena, para atender às suas peculiaridades. Todavia, a superveniência de lei federal sobre normas gerais suspende a eficácia de lei estadual, no que lhe for contrária. 
instalações militares), observados os parâmetros e diretrizes fixadas na lei geral (Lei n ${ }^{\circ}$ 7.661, de 16.05.1988, art. $5^{\mathrm{o}}, \S 2^{\mathrm{o} 125}$ e Lei $\mathrm{n}^{\mathrm{o}} 10.257$, de 10.07.2001).

\subsubsection{Evolução histórica do Município no Brasil}

MARIA GARCIA lembra que o Município no Brasil não é criação legal e preexiste ao Estado, como verdadeiro organismo natural: “A autonomia e o poder político das Câmaras Municipais têm sido ressaltados pelos historiadores como núcleos característicos da formação de nossa nacionalidade. Brasil Bandecchi (p. 34 et seq.) relata como as Câmaras Municipais enviavam seus procuradores diretamente às Cortes para apresentar seus problemas, reivindicações e propostas e para discutir soluções. O município no Brasil Colônia reteve as características de um governo local, em que as Ordenações do Reino eram aplicadas, verificando-se, porém o estrito atendimento aos interesses locais, o que levava muitas vezes à prevalência dos usos e costumes. As Constituições Republicanas enfatizaram sempre a autonomia municipal e o seu peculiar interesse". ${ }^{126}$

125 Lei $n^{\circ} 7.661$, art. $5^{\circ}$, $\S 2^{\circ}$. Normas e diretrizes sobre o uso do solo, do subsolo e das águas, bem como limitações à utilização de imóveis, poderão ser estabelecidas nos Planos de Gerenciamento Costeiro Nacional, Estadual e Municipal, prevalecendo sempre disposições de natureza mais restritiva. 126 Política urbana e a questão habitacional, Cadernos de Direito Constitucional e Ciência Política, no 22, São Paulo, Revista dos Tribunais/Instituto Brasileiro de Direito Constitucional, jan.-mar. 1998, p. 72 96. 
A evolução do Município no Brasil Colônia, ${ }^{127}$ repetido o modelo português sob a vigência das Ordenações Afonsinas, Manuelinas e Filipinas, teve a expansão municipalista restringida pela ideia centralizadora das Capitanias hereditárias. A Constituição Imperial de 1824 instituiu Câmaras Municipais em todas as cidades e vilas existentes e nas mais que para o futuro se criarem (art. 167), com caráter eletivo e presididas pelo vereador mais votado (art. 168).

Até então não havia prefeito, cargo que foi criado pela Província de São Paulo pela Lei 18, de 11.04.1835, como caráter de delegado do Executivo nomeado pelo Presidente da Província, ideia que ganhou aceitação em outras Províncias.

O Dec. 1, de 15.11.1889 ${ }^{128}$, não declarou os Estados membros autônomos, mas soberanos, não sendo exagerada a afirmação de parte da doutrina de que durante os 40 anos em que vigorou a Constituição de 1891 não houve autonomia municipal no Brasil. ${ }^{129}$

127 A respeito da evolução histórica do município: Hely Lopes Meirelles, Direito Municipal Brasileiro, 16 ed., São Paulo, Malheiros, 2008, pp. 25-26; Celso Bastos, O município: sua evolução histórica e suas atuais competências, Cadernos de Direito Constitucional e Ciência Política, vol. 1, São Paulo, Revista dos Tribunais/Instituto Brasileiro de Direito Constitucional, out.dez. 1992, p. 54-76.

128 Art. 3o. Cada um desses Estados, no exercício de sua legítima soberania, decretará oportunamente a sua Constituição definitiva, elegendo os seus corpos deliberantes e os seus Governos locais.

129 Conferir Hely Lopes Meirelles: "O hábito do centralismo, a opressão do coronelismo e a incultura do povo transformaram os Municípios em feudos de políticos truculentos, que mandavam e desmandavam nos 'seus' distritos de influência, como se o Município fosse propriedade particular e o eleitorado um rebanho dócil ao seu poder" (Direito municipal brasileiro, 16 ed., São Paulo, Malheiros, 2008, p. 31-32). Ver ainda sobre o assunto Coronelismo, enxada e voto (O Município e o regime representativo no Brasil), de Vitor Nunes Leal, Rio de Janeiro, 1948. 
A breve Carta de 1934 esboçou certo renascimento do municipalismo, com o delineamento da autonomia e discriminação das rendas municipais (art. 13, § $2^{\circ}, \mathrm{I}$ a V), sucumbindo à Carta do Estado Novo em 1937, que implantou o regime interventorial nos Estados e Municípios, cassando a eletividade dos prefeitos, para só concedê-la aos vereadores (art. 26 e 27), plasmada a disciplina municipal pelo Código das Municipalidades (Dec.- lei $\mathrm{n}^{\mathrm{o}} 1.202$, de 08.04.1939, modificado pelo $\mathrm{n}^{\circ} 5.511$, de 21.05.1943).

Sob ventos redemocratizantes, o municipalismo ganhou corpo na Constituição de 1946, quando foi assegurada autonomia política, administrativa e financeira ao Município nos art. 28 e 29, além da participação em alguns tributos arrecadados pelos Estados e União (art. 15, $\S \S 2^{\circ}$ e $4^{\circ}, 20,21$ e 29$)$. Referida tendência foi refreada pela Carta de 04.01.1967 e pela EC 1, de 17.10.1969 (e especialmente pelos Atos Institucionais), com caráter centralizador à vista do reforço de poderes do Executivo Federal, não obstante manutenção formal da autonomia estadual e municipal.

A esse propósito, convém não olvidar que até 1985 as capitais dos Estados e os Municípios considerados 'Área de Segurança Nacional' não elegiam os respectivos Prefeitos, mesmo após a realização de eleições gerais para Governador de Estado em 1982.

A Carta de 1988 adotou a estrutura tríplice (União, Estados-Membros e Municípios) e não dúplice como é usual no Estado Federado. A partir da Constituição de 1988 três ordens foram estabelecidas, a geral (União), a regional (Estado-Membro) e a local (Município). Vale 
lembrar ainda, que o Brasil adotou o federalismo por segregação, pois as Províncias do Império foram transformadas nos Estados da República, ganhando autonomia.

Há divergências quanto à natureza jurídica do Município: como ente federativo, como ente dotado de status federativo ou ainda entidade condômina de exercício de atribuições constitucionais $^{130}$, no que pese o fato da Municipalidade figurar no art. $1^{\circ}$ da Constituição Federal como integrante em caráter indissolúvel da República Federativa do Brasil.

FERNANDO DIAS MENEZES DE ALMEIDA ${ }^{131}$ sustenta a tese de que a inclusão dos Municípios como entes da Federação pela Constituição de 1988 foi perniciosa para a garantia de sua autonomia real. Observa o autor que a afirmação dos Municípios como entes autônomos, integrantes da Federação, não significa que a Constituição lhes tenha assegurado todos os elementos presentes no regime jurídico da União e dos Estados, e demonstra que ainda que também autônomos, os Municípios não possuem o mesmo regime jurídico da União e dos Estados, nem o mesmo grau de autonomia, porquanto presos a um mesmo modelo de estruturação estatal federal e estadual, notadamente no aspecto de governo ${ }^{132}$, e a uma quase total dependência financeira dos demais entes da Federação para que possam minimamente desempenhar suas competências.

Conclui o estudo no sentido de que "Se a Constituição Federal quer mesmo valorizar

130 A esse propósito conferir José Nilo de Castro, Direito municipal positivo, Belo Horizonte, Del Rey, 2006, p. 27-36.

131 Crítica ao tratamento constitucional do Município como ente da Federação brasileira, Revista de Direito Constitucional e Internacional, vol. 68, São Paulo, Revista dos Tribunais/Instituto Brasileiro de Direito Constitucional, jul.-set. 2009, p. 76-85.

$132 \mathrm{Em}$ contraposição ao exemplo da Federação dos Estados Unidos da América em que há uma grande diversidade de modelos de gestão municipal. 
politicamente os Municípios e garantir-lhes autonomia real - e não apenas nominal-, deveria antes, portanto, seja diretamente, seja por impor parâmetros a serem desenvolvidos no âmbito do direito constitucional estadual - melhor esta segunda hipótese, pelo seu sentido de descentralização -, estabelecer meios para que os Municípios possam estruturar-se segundo modelos mais variados e adaptados à realidade nacional, garantidas suas competências legislativas e materiais. A verdadeira autonomia municipal, em suma, pressupõe adequação à realidade de fato, o que não pode ser antecipado, de modo geral e abstrato, segundo um modelo único aplicável nacionalmente". ${ }^{133}$

De fato, é forçoso convir que a centralização de um modelo nacional de Município não se coaduna com a necessária aderência à realidade local da esfera municipal, sendo razoável o estabelecimento de parâmetros no plano estadual, mormente consideradas as dimensões territoriais do país e as peculiaridades regionais.

De qualquer forma, o Município passou a integrar a organização política do país na condição de ente dotado de status federativo, conjugando autonomia política e administrativa ${ }^{134}$, a teor dos caputs dos art. $1^{\text {o135 }}$ e $18^{136}$ da Constituição Federal, o que demonstra a importância que lhe conferiu o constituinte originário.

133 Idem, p. 85.

134 Sobre autonomia municipal, vale conferir: Regina Maria Macedo Nery Ferrari, Direito Municipal, p. 77-94; Márcio Morrone Xavier, O desenvolvimento histórico da autonomia municipal no Constitucionalismo brasileiro: concentração e desconcentração do poder no Brasil. Revista Assojuris, no 112. Porto Alegre, ASSOJURIS, set.-out. 2008, p. 205-225

135 Art. $1{ }^{\circ}$ A República Federativa do Brasil, formada pela união indissolúvel dos Estados, Municípios e do Distrito Federal, constitui-se em Estado Democrático de Direito e tem como fundamentos...;

136 Art. 18. A organização político-administrativa da República Federativa do Brasil compreende a União, os Estados, o Distrito Federal e os Municípios, todos autônomos, nos termos desta Constituição. 
Não é, contudo, ente federativo, pois não possui representação no Senado Federal, não pode propor emendas à Constituição, não possui Poder Judiciário e Tribunais de Contas (exceção dos municípios do Rio de Janeiro e de São Paulo). Integra a federação, mas não a forma.

É, entretanto, a esfera de poder estatal mais próxima do cidadão e a mais permeável ao controle social e à participação popular.

\subsection{Alcance da locução interesse local}

A competência municipal, no sistema geral de competências que regulamenta o gerenciamento costeiro, é aquela de interesse local e a das funções sociais da cidade ${ }^{137}$, nos termos dispostos na Lei Maior, regulamentadas na Lei $\mathrm{n}^{\circ}$ 10.257, de 10.07.2001 - Estatuto da Cidade, e previstas no plano diretor do Município que, melhor do que nenhum outro ente federativo, conhece sua vocação.

Não obstante o plano diretor englobar a totalidade do Município ${ }^{138}$, esta tese está restrita à análise da área urbana.

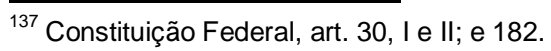
$138 \mathrm{Cf}$. infra 2.5. 
A ordem constitucional vigente assegura ao Município ${ }^{139}$ autonomia municipal compreensiva de quatro capacidades básicas: a) capacidade de auto-organização, pois cada edilidade elabora sua Lei Orgânica própria, regrando suas normas básicas e indispensáveis à sua estrutura política organizacional; b) capacidade de autogoverno, por eleger o representante do Executivo e membros de seu Legislativo; c) capacidade normativa própria, ou capacidade de autolegislação, nas atribuições de elaboração de leis que lhes competem, exclusiva ou suplementarmente; e d) capacidade de autoadministração, mediante gestão própria para as atividades de interesse local. ${ }^{140}$

A expressão "assunto de interesse local" encontrada na Carta de 1988 veio substituir a "de peculiar interesse" consagrada desde a primeira Constituição da República (art. 68 da CF de 1891), seguida pelo art. 13 da Constituição de 1934, art. 26 da Constituição de 1937, art. 28 da Constituição de 1946, art. 16, II da Constituição de 1967 e art. 15, II da EC 1 de 1969.

A conformação do perfil conteudístico da locução "peculiar interesse" foi objeto de intensa celeuma. Nada obstante, a doutrina e a jurisprudência pacificaram o conceito, entendendo que "peculiar interesse" era o interesse predominantemente municipal (eventualmente até mesmo de parte do Município), não sendo exclusivo da localidade, até porque o que é de interesse de uma localidade o é para o Estado-Membro e para o país inteiro.

139 Cf. supra, 2.1

140 Antonio José de Mattos Neto, Competência legislativa municipal sobre meio ambiente. Revista de Direito Ambiental, no 14, São Paulo, Revista dos Tribunais, abr.-jun. 1999, p. 125. 
A respeito da expressão peculiar interesse, utilizada na ordem constitucional pretérita, RÉGIS FERNANDES DE OLIVEIRA observa ${ }^{141}$ : “O peculiar interesse é o não exorbitante dos limites da circunscrição territorial da entidade política, e prepondera sobre os demais interesses que não dizem respeito à vida da comunidade local. (...) Mas quem vai definir o que seja o peculiar interesse do Município é o próprio Município. Na colidência de disposições normativas de outras entidades políticas, deve prevalecer a norma municipal, de vez que é esta quem irá traçar seu âmbito de competência e fixar seus interesses. Não pode a norma federal ou estadual dizer quais são os interesses específicos do Município”.

FERNANDA DIAS MENEZES DE ALMEIDA $^{142}$ ratifica a inexistência de interesse exclusivamente local, restando a solução de eventuais impasses ser dirimida no âmbito do Poder Judiciário: “De fato, a leitura do artigo 30 mostra que as matérias ali enumeradas como de competência do Município guardam pertinência também com interesse das demais pessoas políticas. É inegável que mesmo atividades e serviços tradicionalmente desempenhados pelos Municípios, como transporte coletivo, polícia de edificações, fiscalização das condições de higiene de restaurantes e similares, coleta de lixo, ordenação do uso do solo urbano, etc., dizem secundariamente com o interesse estadual e nacional".

No mesmo trabalho, a autora repudia a tese da diferença de significações peculiar interesse e interesse local: "Muito embora a renúncia a essa tradicional expressão autorize supor que se tenha desejado alterar o critério definidor do 'interesse' que delimita as competências

141 Régis Fernandes de Oliveira e outros, A competência do Município na disciplina urbanística, Revista de Direito Imobiliário, jan.-jun. 1982, p. 09-18. Publicado também em Doutrinas essenciais Direito Registral - volume II, Ricardo Dip e Sérgio Jacomino (Org.), São Paulo, Revista dos Tribunais, 2012 , p. 846.

142 Competências na Constituição de 1988, 2 ed. Atlas, 2000, p. 124-125. 
municipais, parece-nos válido sustentar, na espécie, que a mudança da letra não equivale a uma mudança do espírito da Constituição".

Por oportuno, o entendimento esposado deve ser prestigiado, pois não se vislumbra relevante distinção conteudística entre as expressões peculiar interesse e interesse local.

REGINA MARIA MACEDO NERY FERRARI ${ }^{143}$, em denso trabalho sobre direito municipal, também adere ao critério da predominância do interesse, relegando à casuística sua definição ${ }^{144}$ : "Foi este mesmo critério, o da predominância do interesse, que norteou o Constituinte Federal de 1988, do que se pode concluir que os assuntos de interesse local, dentro da melhor técnica legislativa, serão definidos estudando-se, caso a caso, qual o interesse predominante ara fixação da competência do Município. Dessa forma, a lei municipal deve prevalecer em todas as matérias que demonstrarem interesse apenas ou preponderantemente à comuna, e, consequentemente, a lei federal ou estadual que venha a violar este campo de autonomia do Município incorrerá em inconstitucionalidade, por desatender à repartição de competências prevista na Lei Maior do Estado brasileiro. Ressaltese, por oportuno, que interesse local não quer dizer interesse único e privativo do Municípios. Não há interesse local que também não seja reflexamente da União e dos Estados-membros, como não há interesse nacional ou regional que não se reflita nos Municípios, como parte integrante de uma realidade maior que é a Federação brasileira".

143 Direito municipal, p. 101

144 Ver sobre interesse local do Município: Talden Farias, A repartição de competências para o licenciamento ambiental e a atuação dos municípios, Revista de Direito Ambiental, no 43, São Paulo, Revista dos Tribunais, jul.-set. 2006, p. 260; da mesma autora, Instrumentos legais e normativos de competência municipal em matéria ambiental, Revista de Direito Ambiental, no 31, jul./set. 2003, p. 100 116; Silvia Capelli, Inserção do Município no SISNAMA: implementação de Conselhos e Fundos, in Efetividade da tutela ambiental, Jarbas Soares Júnior, Marcos Paulo de Souza Miranda e Sheila Cavalcante Pitombeira (Org.), Belo Horizonte, Del Rey, 2008, p. 55-70. 
Nesse sentido, há que se reconhecer a vantagem de não se elencar o rol de matérias que diz respeito aos interesses de prevalências locais, na área de competência legislativa municipal, tendo em vista a dinâmica do espaço urbano, marcada pela heterogeneidade dos interesses coexistentes e a complexidade das relações sociais ali estabelecidas.

Por consequência, o conceito de interesse local tende a se alargar, onerando cada vez mais o Município por conta do fenômeno irreversível da urbanização, ${ }^{145}$ pois quando o objeto de proteção for qualidade de vida e bem estar da população, o assunto será de consideração do direito urbanístico. ${ }^{146}$

145 Interessante a atualidade do estudo realizado por Diogo Lordello de Mello, no distante ano de 1974, divisor do 'milagre econômico' com a 'crise do petróleo' dos impactos da urbanização na atividade administrativa do Município: "aumento da demanda por serviços públicos; elevação das aspirações populares quanto ao aspecto qualitativos dos serviços, pois cada vez se deseja mais e melhor; elevação da complexidade e custos dos serviços urbanos em função da economia de escala, com investimentos em recursos humanos, tecnologia, infraestrutura e métodos; necessidade de novos mecanismos de ação governamental, como o cooperativismo, divisão de responsabilidades, federalismo cooperativo, participação popular; deterioração do meio ambiente; desemprego" ( $O$ fenômeno urbano no Brasil, in. O Município e o direito urbano, IBAM - 1974, p. 23-26. Texto baseado em notas taquigráficas da conferência pronunciada em 07.05 .1973 , ao instalar no auditório do IBAM o Seminário sobre Direito Urbano).

146 É o entendimento de Marcelo Abelha Rodrigues: "Basta que se inaugure a construção de um condomínio em área urbana à beira-mar e será necessária a existência de uma licença ambiental que levará em consideração a afetação ao equilíbrio ecológico deste empreendimento (sujeita ao órgão ambiental competente), tal como a descarga de esgotos, o sombreamento permanente da praia, a destruição da vegetação local etc. A par disso, deve haver também uma licença urbanística que cuidará de aspectos relacionados diretamente com a qualidade de vida da população local, tais como a perda da qualidade da paisagem local, altura do calçamento, nivelamento da construção com a rua, projeto arquitetônico, aumento do trânsito, etc." (Instituições de direito ambiental, São Paulo, Max Limonad, 2002, p. 65). 
Impende salientar que quanto mais os Municípios se preparam e se especializam para o trato das questões complexas da vida em sociedade, maiores adequações vão sendo imprescindíveis.

Convém também aludir ao princípio da subsidiariedade ${ }^{147}$, vez que nenhuma função será desempenhada por ente federativo superior se um ente federativo inferior estiver em condições de exercê-la. ${ }^{148}$ Isso não significa afastar a competência dos entes superiores, que permanecem em seu exercício supletivo nas hipóteses de omissão ou inépcia do ente federativo inferior.

Em outra via, há situações nas quais a competência supletiva será do ente inferior, desde que caracterizada a prevalência do interesse geral ou de competência típica do ente superior, bem como não edite leis menos restritivas do que aquelas estabelecidas nos planos superiores.

Destarte, os critérios que demarcam a competência municipal são os do interesse local e o das funções sociais da cidade, pois compete ao Município, entre outras atribuições que lhe são conferidas pela Constituição da República, "legislar sobre assuntos de interesse local” (art. 30, I), e "suplementar a legislação federal e a estadual no que couber." O art. 182 da Constituição,

147 Vanesca Buzelato Preste observa: "O processo de municipalização de políticas públicas decorre do próprio Estado Federativo com a participação de três entes (União, Estados e Municípios) e traz ínsito ao seu conceito os princípios da subsidiariedade e da descentralização. Disto decorre o reconhecimento de competências próprias municipais e, mais do que isto, de deveres decorrentes desta assunção de competências, aliado à participação da população tanto no processo decisório quanto da execução em si. É por isso que existem os conselhos setoriais de meio ambiente, saúde, educação, criança e adolescente, assistência social, etc." (A necessidade de compatibilização das licenças ambiental e urbanística no processo de municipalização do licenciamento ambiental, Revista de Direito Ambiental, no 34, São Paulo, Revista dos Tribunais, abr.-jul. 2004, p. 84).

148 Celso Bastos e Yves Gandra Martins, Comentários à Constituição do Brasil, v. 1, 2 ed., São Paulo, Saraiva, 1000, p. 46. 
por sua vez incumbe ao poder público municipal executar a política do desenvolvimento urbano, tendo como objetivo "ordenar as funções sociais da cidade e garantir o bem estar de seus habitantes".

O interesse local, portanto, é aquele que de forma direta e imediata atinge a comunidade que vive o problema a solucionar pelo poder legislativo municipal. Por tal motivo, a competência do Município é exclusiva, não podendo delegar a nenhum outro ente político o poder de legislar o interesse que lhe é próprio e particular (local)". ${ }^{149}$

Dessa forma, a matéria objeto de legislação municipal sobre interesse local, pode ser multiplicada ad infinitum, vez que seus contornos são os limites que o próprio entendimento da locução pressupõe. Por certo, matérias estritamente ligadas à defesa nacional ou a bens de domínio e inquestionável interesse da União, como o mar territorial e a plataforma continental não são alcançadas pela abrangência da locução. ${ }^{150}$

A guisa de breve conclusão, firma-se o entendimento de que a distinção estabelecida entre peculiar interesse e interesse local é despida de maior relevância. Outrossim, a concreção do referido interesse se efetivará caso a caso, pelo próprio Município na realização dos interesses políticos, financeiros e sociais decorrentes de sua capacidade de auto organização,

149 Competência legislativa municipal sobre meio ambiente. Revista de Direito Ambiental, n. 14, abr.jun. 1999, p. 128-129.

150 Nesse sentido, é lícito aduzir às restrições militares, comuns no Rio de Janeiro (Forte de Copacabana, praias de Fora e de Dentro da Urca, Imbuí e do Forte Rio Branco em Niterói), justificadas por razões de segurança, haja vista as atividades ali desenvolvidas, bem como ambientais, mantendoas, assim, preservadas. 
autogoverno, auto administração e normatização, toda vez que a realização do interesse local estiver ameaçada ou comprometida, preponderando este sobre os demais entes federativos, exceção feita às hipóteses de omissão ou inépcia do Município, por força do princípio da subsidiariedade. ${ }^{151}$

\subsection{Participação do Município no Plano Nacional de Gerenciamento Costeiro}

Conforme salientado no curso deste trabalho ${ }^{152}$, a execução das ações previstas no Plano Nacional de Gerenciamento Costeiro - PNGC observará a divisão de competências dispostas na Lei $\mathrm{n}^{\circ} 7.661$, de 16.05.1988 e no Decreto $\mathrm{n}^{\circ} 5.300$, de 07.12.2004, desde os aspectos relacionados às diretrizes gerais reservadas à União, aqui representada pelo Ministério do Meio Ambiente/IBAMA, até a esfera de maior concreção e execução, como a municipal. ${ }^{153}$

151 O debate em torno do tema tem sido alvo de preocupação também no direito estrangeiro. Ao tratar da divisão de competências no direito espanhol, Juan Manuel Baragán Muñoz, lembra que o arcabouço formado pelos art. 148 e 149 da Constituição Espanhola, reserva ao poder local o mínimo de competências conferidas diretamente pela Constituição, tais como urbanísticas, sanitária, segurança e limpeza das praias, eliminação de áquas residuais, reservadas ao Estado e às Comunidades Autônomas grande parte das funções públicas que podem ser encontradas no litoral (La gestión de áreas litorales em España y Latinoamérica, p. 147-148). Em resposta à Recomendação 2002/413/CE do Parlamento Europeu e do Conselho de 30.05.2002 e Recomendação 160/2005 do Conselho da Europa, Portugal elaborou as Bases para a Estratégia de Gestão Integrada das Zonas Costeiras Nacionais (BEGIZCN, 2007), com viés fortemente voltado a prestigiar o plano local na gestão do espaço costeiro, conforme se verifica dos princípios da: Subsidiariedade - coordenando os procedimentos dos diversos níveis da Administração Pública, de forma a privilegiar o nível decisório mais próximo do cidadão; Participação - potenciando o activo envolvimento do público, das instituições e agentes locais e reforçando a consciência cívica dos cidadãos, através do acesso à informação e à intervenção nos procedimentos de elaboração, execução, avaliação e revisão dos instrumentos de gestão territorial; Corresponsabilização - assumindo a partilha da responsabilidade nas opções de gestão da zona costeira com a comunidade, os agentes econômicos, os cidadãos e associações representativas, não só pelo princípio do poluidor-pagador e do utilizador-pagador, mas também pela procura de formas institucionais que permitam uma gestão mais próxima dos cidadãos e dos utentes da zona costeira (Filomena Martins e Henrique Albuquerque, cit., p.339).

152 Cf. supra 1.2.2.

153 Art. 11 a 14 do Decreto oㅜ 5.300, de 07.12.2004. 
Os Estados, na esfera de suas competências, planejarão e executarão as atividades de gerenciamento costeiro em articulação intergovernamental, com os municípios e com a sociedade.

Acresce notar a competência estadual para integrar a organização, o planejamento e a execução de funções públicas de interesse comum nas regiões metropolitanas, aglomerações urbanas e microrregiões ${ }^{154}$, valendo aqui aludir aos art. 30 e 31 da Lei $n^{\mathbf{o}} 11.428$, de 22.12.2006, quanto à proteção do bioma Mata Atlântica nas áreas urbanas e regiões metropolitanas.

Os Municípios, observadas as normas e os padrões federais ${ }^{155}$ e estaduais ${ }^{156}$, planejarão e executarão suas atividades de gerenciamento costeiro em articulação intergovernamental e com a sociedade. ${ }^{157}$

154 Constituição Federal, art. 25, § 3․․

155 Art. 11 e 12.

156 Art. 13.

157 Competência dos Municípios, observadas as normas e os padrões federais e estaduais: Ielaborar, implementar, executar e acompanhar o PMGC, observadas as diretrizes do PNGC e do $P E G C$, bem como o seu detalhamento constante dos Planos de Intervenção da orla marítima, conforme previsto no art. 25 do Decreto no 5.300/04; II-estruturar o sistema municipal de informações da gestão da zona costeira; III - estruturar, implementar e executar os programas de monitoramento; IV-promover o fortalecimento das entidades diretamente envolvidas no gerenciamento costeiro, mediante apoio técnico, financeiro e metodológico; $V$-promover a compatibilização de seus instrumentos de ordenamento territorial com o zoneamento estadual; $\mathrm{VI}$ promover a estruturação de um colegiado municipal. 
Isso não significa que o zoneamento estadual seja o somatório dos zoneamentos municipais, e que o zoneamento nacional seja o somatório dos zoneamentos estaduais, pois cada esfera apresenta objetivos específicos ligados diretamente à escala de trabalho envolvida e dinâmicas que transcendem a somatória dos zoneamentos das unidades políticas que a compõe ". ${ }^{158}$

Em relação às regras de uso e ocupação da zona costeira, o Decreto $\mathrm{n}^{\circ} 5.300$, de 07.12.2004 ${ }^{159}$ estabelece critérios e providências a serem observados por ocasião da instalação, ampliação ou realocação de empreendimentos ou atividades que importem na modificação ou mesmo supressão da vegetação nativa e de suas características socioambientais originais.

Assim, o financiamento de projetos novos ou ampliação de empreendimentos na zona costeira com recursos da União, de fontes externas por ela avalizadas ou de entidades de crédito oficiais, bem como a concessão de benefícios fiscais, é condicionado à compatibilidade com normas e diretrizes de planejamento territorial e ambiental do Estado e do Município, principalmente aquelas constantes dos PEGC, PMGC e do ZEEC.

158 Ver sobre o assunto: Leonardo Zagonel Serafini, O zoneamento costeiro e as competências municipais: uma análise à luz da legislação ambiental brasileira. Revista de Direitos Difusos, vol. 30, Teses de Foz do Iguaçú II, Rio de Janeiro, ADCOAS, mar.-abr. 2005, p. 18.

159 Art. 16 a 18. 
Cumpre salientar que os Estados que não dispuserem de ZEEC orientar-se-ão por meio de outros instrumentos de ordenamento territorial, como zoneamentos regionais ou agrícolas, de unidades de conservação e diagnósticos sócio ambientais, que permitam avaliar as condições naturais e socioeconômicas relacionadas à implantação de novos empreendimentos.

O sistema de competências, estatuído pelos art. 30 e 31 do Decreto $n^{\circ} 5.300$, de $07.12 .2004^{160}$ atribui ao Ministério do Meio Ambiente, em articulação com o IBAMA e os órgãos estaduais de meio ambiente, por intermédio da Coordenação do PEGC, preparar e manter atualizados os fundamentos técnicos e normativos para a gestão da orla marítima, provendo meios para capacitação e assistência aos Municípios.

MARIA LUIZA MACHADO GRANZIERA observa que os Planos Estaduais e Municipais de Gerenciamento Costeiro devem estabelecer: 1. Os princípios, objetivos e diretrizes da política de gestão da zona costeira da sua área de atuação; 2. O Sistema de Gestão Costeira na sua área de atuação; 3. Os instrumentos de gestão; 4. As infrações e penalidades previstas em lei; 5. Os mecanismos econômicos que garantam a sua aplicação. ${ }^{161}$

160 Art. 30. Compete ao Ministério do Meio Ambiente, em articulação com o IBAMA e os órgãos estaduais de meio ambiente, por intermédio da Coordenação do PEGC, preparar e manter atualizados os fundamentos técnicos e normativos para a gestão da orla marítima, provendo meios para capacitação e assistência aos Municípios.

Art. 31. Compete aos órgãos estaduais de meio ambiente, em articulação com as Gerências Regionais de Patrimônio da União, disponibilizar informações e acompanhar as ações de capacitação e assistência técnica às prefeituras e gestores locais, para estruturação e implementação do Plano de Intervenção.

161 Direito ambiental, 2 ed., São Paulo, Atlas, 2011, p. 580-582. 
A autora alerta para a necessidade de instituição de órgãos ou entidades competentes para sua execução, pois o plano há de ser "realista e factível, proporcionalmente, inclusive, à capacidade da Administração Pública para implementar suas diretrizes e fiscalizar as ações desenvolvidas no espaço", e conclui, "o instrumento desconectado com o cenário que vigora tem muito menos chances de tornar-se exequível".

Enfim, caberá ao Poder Público Municipal elaborar e executar o Plano de Intervenção da Orla Marítima de modo participativo com o colegiado municipal, órgãos, instituições e organizações da sociedade interessados, lançando mão dos inúmeros instrumentos postos à sua disposição no Decreto $\mathrm{n}^{\mathrm{o}} 5.300$, de $07.12 .2004^{162}$, de acordo com classificação que leve em conta aspectos físicos e processos de uso e ocupação da orla marítima. ${ }^{163}$

162 Art. 32. Compete ao Poder Público Municipal elaborar e executar o Plano de Intervenção da Orla Marítima de modo participativo com o colegiado municipal, órgãos, instituições e organizações da sociedade interessados.

Art. $7^{0}$ Aplicam-se para a gestão da zona costeira os seguintes instrumentos, de forma articulada e integrada: I-Plano Nacional de Gerenciamento Costeiro-PNGC: conjunto de diretrizes gerais aplicáveis nas diferentes esferas de governo e escalas de atuação, orientando a implementação de políticas, planos e programas voltados ao desenvolvimento sustentável da zona costeira; II - Plano de Ação Federal da Zona Costeira - PAF: planejamento de ações estratégicas para a integração de políticas públicas incidentes na zona costeira, buscando responsabilidades compartilhadas de atuação; III-Plano Estadual de Gerenciamento Costeiro-PEGC: implementa a Política Estadual de Gerenciamento Costeiro, define responsabilidades e procedimentos institucionais para a sua execução, tendo como base o PNGC; IV - Plano Municipal de Gerenciamento Costeiro - PMGC: implementa a Política Municipal de Gerenciamento Costeiro, define responsabilidades e procedimentos institucionais para a sua execução, tendo como base o PNGC e o PEGC, devendo observar, ainda, os demais planos de uso e ocupação territorial ou outros instrumentos de planejamento municipal; $V$ - Sistema de Informações do Gerenciamento Costeiro-SIGERCO: componente do Sistema Nacional de Informações sobre Meio Ambiente - SINIMA, que integra informações georreferenciadas sobre a zona costeira; VI - Sistema de Monitoramento Ambiental da Zona Costeira - SMA: estrutura operacional de coleta contínua de dados e informações, para o acompanhamento da dinâmica de uso e ocupação da zona costeira e avaliação das metas de qualidade socioambiental; VII-Relatório de Qualidade Ambiental da Zona Costeira-RQA-ZC: consolida, periodicamente, os resultados produzidos pelo monitoramento ambiental e avalia a eficiência e eficácia das ações da gestão; VIII - Zoneamento Ecológico-Econômico Costeiro - ZEEC: orienta o processo de ordenamento territorial, necessário para a obtenção das condições de sustentabilidade do desenvolvimento da zona costeira, em consonância com as diretrizes do Zoneamento Ecológico-Econômico do território nacional, como mecanismo de apoio às ações de monitoramento, licenciamento, fiscalização e gestão; IX - macrodiagnóstico da zona costeira: reúne informações, em escala nacional, sobre as características físico-naturais e 
A importância da atuação da autoridade local também é destacada pela Agenda $21^{164}$ : "As autoridades locais constroem, operam e mantêm a infraestrutura econômica, social e ambiental, supervisionam o processo de planejamento, estabelecem as políticas e regulamentações ambientais locais e contribuem para a implementação de políticas ambientais nacionais e subnacionais. Como nível de governo mais próximo do povo, desempenham um papel essencial na educação, mobilização e resposta ao público, em favor de um desenvolvimento sustentável."165

A preponderância da instância municipal também é reconhecida por SHEILA CAVALCANTE PITOMBEIRA ${ }^{166}$, ao tratar dos inúmeros aspectos que o Plano de Gerenciamento Costeiro deve abordar: "De acordo com as disposições do art. $5^{\circ}$ da Lei n $^{\circ}$ 7.661/1988, o plano deve, necessariamente, contemplar os seguintes aspectos: urbanização, ocupação e uso do solo, subsolo e das águas, parcelamento e remembramento do solo; sistema

socioeconômicas da zona costeira, com a finalidade de orientar ações de preservação, conservação, regulamentação e fiscalização dos patrimônios naturais e culturais.

Art. 29. Para execução das ações de gestão na orla marítima em áreas de domínio da União, poderão ser celebrados convênios ou contratos entre a Secretaria do Patrimônio da União e os Municípios, nos termos da legislação vigente, considerando como requisito o Plano de Intervenção da orla marítima e suas diretrizes para o trecho considerado.

163 Art. 26. Para a caracterização socioambiental, classificação e planejamento da gestão, a orla marítima será enquadrada segundo aspectos físicos e processos de uso e ocupação predominantes, de acordo com as seguintes tipologias: I - abrigada não urbanizada; II - semiabrigada não urbanizada; III - exposta não urbanizada; IV - de interesse especial em áreas não urbanizadas; $V$ - abrigada em processo de urbanização; VI - semiabrigada em processo de urbanização; VII - exposta em processo de urbanização; VIII - de interesse especial em áreas em processo de urbanização; IX - abrigada com urbanização consolidada; $X$-semiabrigada com urbanização consolidada; XI-exposta com urbanização consolidada; XII - de interesse especial em áreas com urbanização consolidada.

164 Cf. supra 1.1.2.

165 Agenda 21 - Conferência das Nações Unidas sobre Meio Ambiente e Desenvolvimento. 3ª ed. Brasília: Senado Federal, Subsecretaria de Edições Técnicas, 2000, p. 473.

166 Gerenciamento costeiro, In Marcelo Buzaglo Dantas, Elida Séguin e Flávio Ahmet - O direito ambiental na atualidade - estudos em homenagem a Guilherme José Purvin de Figueiredo, Rio de Janeiro, Lumen Juris, 2010, p. 437-452. 
viário e de transporte; sistema de produção, transmissão e distribuição de energia; habitação e saneamento básico, turismo, recreação e lazer; patrimônio natural, histórico, étnico, cultural e paisagístico. Assim, observando-se as disposições do art. $5^{\circ}$ da Lei $n^{\circ} 7.661$, de 16.05.1988 retrocitada, verifica-se que alguns dos aspectos indispensáveis à sua elaboração, como atividade socioeconômica, uso e ocupação do solo e saneamento básico são questões mais próximas dos Municípios e dos Estados. Tal fato evidencia a razoabilidade de os Estados e Municípios litorâneos elaborarem os respectivos Planos de Gerenciamento Costeiro, uma vez que têm competência para tal e até dispõem de maiores condições de ajustar a realidade de suas características naturais e aspectos socioeconômicos aos comandos legais de gestão da Zona Costeira”.

Outro aspecto a ser salientado é que a participação do cidadão munícipe nas decisões que afetam a comunidade ${ }^{167}$ ocorre com maior eficácia no nível decisório local do que no regional ou no distante plano nacional. ${ }^{168} \mathrm{~A}$ voz do munícipe, especialmente nas cidades pequenas, se

167 Cf. supra 2.2.

168 A legislação de Cubatão prevê a participação popular nas decisões relativas à administração do

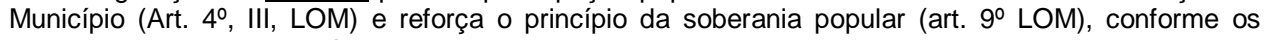
ditames constitucionais. Os mecanismos e os meios de participação para tanto, encontram-se assegurados no art. 11 da LOM, que além do sufrágio universal prevê: plebiscito, referendo, iniciativa popular em processo legislativo, participação popular nas decisões do Município e no aperfeiçoamento democrático de suas instituições; ação fiscalizadora sobre a administração pública. Tribuna livre no anfiteatro da Câmara Municipal (Diagnóstico Urbano Socioambiental - Município de Cubatão - Bases das Informações até 2012 - Revisão Março de 2013 - Convênio Petrobrás Instituto Polis - Relatório n⿳亠口冖 6 , p. 50). A Agenda 21 é o espaço de gestão participativa de maior visibilidade no município. Hoje a Agenda 21 é uma política pública encampada pela gestão municipal que, seis anos depois de sua concepção, avalia que a cidade progrediu e caminha rumo aos objetivos traçados. Os avanços mais significativos parecem ter se dado em três setores: empregabilidade, educação/qualificação profissional e saúde.

Além da vocação industrial foram apontadas outras quatro potencialidades que, se fortalecidas e incentivadas pelo poder público/privado, podem contribuir para o desenvolvimento sustentável: promoção da cultura nordestina e da identidade local; projetos de geração de renda de cunho cooperativo aos moldes da economia solidária (padarias comunitárias, cooperativas de material reciclável, etc.); turismo de aventura/ecoturismo ou turismo industrial e de negócios; pesca artesanal ( $p$. 77).

A Lei $n^{\circ}$ 913, de 23.06.2010 de Bertioga Criou a Casa dos Conselhos como instância municipal, congregando em uma única sede todos os Conselhos constituídos no município. 
faz mais forte nas decisões que afetam aspectos do desenvolvimento local, tais como uso e ocupação do solo, regulamentação das atividades desenvolvidas na zona urbana (pelo exercício do poder de polícia ou por meios menos intrusivos), circulação, tráfego e saneamento, entre outros.

JOSÉ AFONSO DA SILVA lembra que o planejamento urbano, para atingir seus objetivos, terá que atender a certos critérios fundamentais, tais como a sensibilidade às demandas sociais. "Os planos devem ser sensíveis às aspirações populares. São bons os planos quando leva em conta o bem-estar do povo, quando são sensíveis às necessidades e aspirações deste. Aliás, o objetivo primordial de qualquer plano de governo é sempre a satisfação das necessidades do povo." ${ }^{169}$ Referido critério só pode ser aferido em sua plenitude pelo poder local, mediante consulta à comunidade envolvida.

JOHN VERNBERG e WINONA VERNBERG reconhecem que a participação da comunidade se dá com maior eficácia no plano local ${ }^{170}$, noticiando circunstâncias nas quais a

Santos também é uma cidade que se destaca, em termos organizativos, por abrigar uma profusão dos mais diversos tipos de organizações da sociedade civil e por concentrar em seu território uma gama de conflitos e de interesses característicos de cidade grande: movimentos sociais e sindicais típicos, ONGs, organizações representativas de grandes interesses empresariais e industriais de âmbito nacional, etc. O espaço de gestão participativa encontra-se plasmado nos instrumentos previstos no art. $1^{\circ}$ da Lei Orgânica: sufrágio universal por meio do voto direto e secreto; plebiscito a respeito de questões relevantes, quando ao menos um por cento do eleitorado o requerer ao TRE, ouvida a Câmara; referendo, quando ao menos um por cento do eleitorado o requerer à Câmara; veto; iniciativa popular no processo legislativo, entre outros previstos em diversos dispositivos (Diagnóstico Urbano Socioambiental - Município de Santos - Bases das Informações até 2012 - Revisão Março de 2013 Convênio Petrobrás Instituto Polis - Relatório nª 6, pp. 31/41).

A Lei no 8.655 , de 30.07.2008, do município de Belém prevê nos art. 212 e 213 a realização de uma Conferência Municipal da Cidade de Belém a cada dois anos, para discutir as diretrizes urbanas, aberto à participação de qualquer indivíduo, com forte ênfase nos recursos hídricos, bacias e defesa de lençóis freáticos.

169 Direito urbanístico, p. 107.

170 Os autores relacionam também os diversos atos que normatizam a zona costeira Americana, no plano nacional e regional, valendo destacar: The national environmental policy act (1969), the coastal 
insatisfação com a política de desenvolvimento proporcionou o surgimento de novas cidades para que as comunidades tivessem voz. ${ }^{171}$

Os autores sinalizam tendência ao fortalecimento do plano local na zona costeira, não se olvidando da reserva que o norte americano tem pelo poder central, salientando que o plano local é nota característica da sua cosmovisão indutivista e empirista, da qual decorreu o autêntico federalismo por agregação, afinal 'é muito mais fácil falar com um membro do Conselho local do que com um membro do Congresso'. ${ }^{172}$

Portanto, referido zoneamento municipal dever ser realizado no âmbito do arcabouço desenhado pelo plano diretor ${ }^{173}$, instrumento previsto no art. 182 da Constituição Federal,

zone manegement act (1972), U.S. Army Corps of engineers' programs, the clean water act (1972), the clean air act (1972), national flood insurance act, Federal disaster assistance, The national estuarine research reserve program, The national marine sanctuaries program (1972), The coastal barrier resources act, The national estuary program (1987), CZMA special area management plans, The endangered species act (The coastal zone, past, present and future, p. 132-144).

171 "Progressivamente, cidadãos perceberam a obrigatoriedade do envolvimento no governo local para que possam influenciar o futuro de suas comunidades. Municípios estão surgindo através da zona costeira Americana exatamente por essa razão. Cidadãos querem que as decisões concernentes às suas comunidades sejam tomadas o mais próximo possível do eleitorado. Assim, pequenos municípios oferecem a oportunidade para o envolvimento da comunidade na determinação de seu futuro. Na costa da Carolina do Sul, novos municípios surgiram nos últimos anos, como Litchfield Beach, Pawleys Island, Hilton Head Island, Kiawah Island and Seabrook Island. Esse quadro foi criado por moradores que queriam o desenvolvimento sustentável de suas comunidades. Eles não estavam satisfeitos com a política de desenvolvimento praticada pelos governos de seus respectivos condados" (Idem, p. 144).

172 Cit., p. 145. Ademais, estimavam que no início do século XXI $70 \%$ da população norte americana residiria na zona costeira ou em sua área de influência geoeconômica, salientando ainda interessante aspecto sociológico do alto percentual de aposentados que procuram a região para fixar residência ( $p$. 146-147).

173 Cf. infra 2.5 . 
regulamentado pela Lei $\mathrm{n}^{\mathrm{o}} 10.257$, de 10.07.2001 e efetivado por meio de decreto ${ }^{174}$, para que se determine a aplicação das normas legais às zonas identificadas no processo de zoneamento.

Em suma, a questão reside em conjugar a participação da comunidade com os dois instrumentos de ordenamento do uso do solo e das atividades ali desenvolvidas, à disposição das autoridades locais: o zoneamento costeiro, com destaque ao Projeto Orla, e o zoneamento urbano decorrente do plano diretor municipal. Muito embora apresentem finalidades distintas, na escala municipal, estas finalidades se aproximam bastante, especialmente no combate à ocupação quase descontrolada da zona costeira.

\subsection{Gestão municipal nos terrenos de marinha e acrescidos}

Este trabalho defende a tese de que a consolidação dos terrenos de marinha e acrescidos na esfera municipal constitui uma das medidas necessárias ao desenvolvimento da zona costeira urbana, cabendo ao Município assegurar a tutela do interesse local na região por meio da utilização dos instrumentos previstos na Lei $\mathrm{n}^{\circ} 10.257$, de 10.07 .200 , da participação no Projeto Orla, entre outros recursos.

174 Sem dúvida que o decreto permite maior flexibilidade no que diz respeito à sua atualização periódica, o que não ocorre com a lei, vinculada às regras e vicissitudes do processo legislativo, todavia, permite ao Prefeito sua modificação nem sempre pautada no interesse público. 
Em abono a esta tese, a par das razões defendidas neste capítulo e da tramitação de dois projetos de emendas à Constituição, vale lembrar que a titularidade dos terrenos de marinha pela União nem sempre foi pacífica, ${ }^{175}$ sendo marcada por embates havidos na doutrina e no legislativo pátrio no final do século XIX e início do século XX, com relevantes argumentos de lado a lado. Durante o período, com o fito de promover o povoamento das cidades litorâneas, diversas leis autorizaram o aforamento pelas Câmaras locais. ${ }^{176}$

Apenas com o advento da República é que, pela Lei $n^{\circ} 25$, de 30.12.1891, o privilégio dos entes locais foi revertido à União e, deixando de aplicar o aforamento em prol da ocupação, o interesse local defendido pela municipalidade restou desprotegido, como será visto adiante. Ainda assim, a defesa dos interesses municipais pode se identificado nos art. $12,1^{\circ}, \S 2^{\circ}$, do Dec.-lei no 2.490, de 16.08.1940; 7º “a”, § 4º do Dec.-lei no 3.438, de 17.07.1941; 100, “d”, do Dec.-lei no 9.760, de 05.09.1946.

175 Cf. supra 1.3.2.

176 João Alfredo Raymundo e Silva faz precioso histórico da legislação, contrapondo o interesse nacional ao local, a partir do cotejo das competências atribuídas à União e às Municipalidades, desde a Ordem Régia de 07.05.1725 até o regramento contemporâneo (Terrenos de marinha, seus acrescidos e a Administração Municipal, Revista de Direito Público, no 37-38, São Paulo, Revista dos Tribunais, jan.-jun. 1976, p. 316-326).

Antonio Chaves relata que, a princípio, as opiniões estavam divididas, com João Barbalho e Galdino Loreto sustentando que os terrenos de marinha, com as terras devolutas, tinham sido entregues pela Constituição aos Estados, ou deixados aos Municípios. Carlos de Carvalho e Carvalho de Mendonça entendiam que eram bens do patrimônio da União, prevalecendo parecer do então Procurador Geral da República Epitácio Pessoa, exarado na "questão dos Estados" - processo sobre exploração de monazite envolvendo os estados da Bahia e Espírito Santo -, como sendo uma extensa faixa territorial que aperta em um todo bem unido os diversos Estados da República e ao mesmo tempo mostra, pelo lado do mar, um contato entre o Brasil e as nações estrangeiras, que se há de dar por intermédio da União (cit., p. 14). 
Conforme debatido no curso deste trabalho ${ }^{177}$, a gestão municipal das atividades exercidas em terreno de marinha traz a lume problemas decorrentes da sobreposição de competências da União (dominial do bem) com o Município (regramento de atividades que lhes são próprias do interesse local). As praias marítimas, o mar territorial e os terrenos de marinha, embora sendo bens da União, localizam-se, não obstante, no território de algum município e, como parte desse território, incluem-se no âmbito da autonomia municipal e da respectiva jurisdição.

Portanto, as construções realizadas nos terrenos de marinha e as atividades ali desenvolvidas, no caso de áreas urbanas ou urbanizáveis, ficam sujeitas a regulamentação e a tributação municipal, como as demais realizações particulares. ${ }^{178}$

Para a realização do interesse local nessa área, o Administração Municipal poderá agir de forma mais ou menos extroversa, mediante a edição de ato ou promoção de processo que leve em conta maior participação dos titulares dos direitos e interesses em jogo, objetivando algum grau de consenso que otimize a decisão final.

177 Cf. supra 1.3.1.

178 Sérgio Sérvulo da Cunha observa que a população do município, titular não exclusiva do direito de uso dessas áreas, faz delas variado proveito, com objetivo econômico ou de lazer: "Elas não se prestam apenas, e eventualmente, à circulação, mas também, à urbanização (no caso principalmente dos térreos de marinha, cujo uso pode ser cedido a particular). Aqui o município exerce o seu poder de polícia como em qualquer outra área do seu território, disciplinando as edificações, o trânsito, a higiene, lançando tributos, fiscalizando e impondo sanções. Por outro lado os bens e atividades do próprio Estado-membro e da União existentes ou desenvolvidas nessas áreas - à parte a imunidade tributária - sujeitam-se ao poder de polícia local, conforme definido em lei (...). Na prática, existe uma tendência burocrática à exorbitância e multiplicação de exigências (...). É de todo conveniente, principalmente nos municípios litorâneos mais populosos em que é maior a frequência dos casos, a criação de mecanismos e instâncias comuns, para administrar não só os possíveis conflitos administrativos, mas para evitar a duplicidade de procedimentos, quando se trata de interesses de particulares" (Município: Poder de Polícia sobre a Zona Costeira. Revista dos Tribunais, n. 686, São Paulo, Revista dos Tribunais p. 269-273, dez. 1992). 
Nesse diapasão, a tendência ao alargamento da competência municipal é vislumbrada em todos os aspectos que envolvem o uso e ocupação do solo da orla marítima, inclusive os terrenos de marinha, bem como a disciplina das atividades ali desenvolvidas, observados os imperativos da ordem constitucional e as balizas federativas.

Ainda que se admita reserva dominial da União, unicamente, para fins de defesa nacional, sem restringir a competência estadual e municipal no ordenamento territorial e urbanístico dos terrenos de marinha, o desenvolvimento tecnológico dos sistemas de defesa (satélites e aeronaves, inclusive não tripuladas), tornou inútil a manutenção do centenário instituto. Caso necessário, o acesso à faixa de marinha pode ser assegurado pelo manejo de instrumentos de intervenção na propriedade privada, tais como a requisição temporária, servidão administrativa e desapropriação, o que apenas reforça a desnecessidade do instituto.

Desse modo, o exercício do interesse local pelo Município pode se dar de forma ampla e desembaraçada, sem a constante e prejudicial interferência da União, sempre distante da intensa e dinâmica realidade local que o Município, melhor do que qualquer outra esfera conhece.

$\mathrm{O}$ art. $4^{\mathrm{o}}$ da $\mathrm{LF} \mathrm{n}^{\mathrm{o}}$ 9.636, de $15.05 .1998^{179}$ prevê a possibilidade de celebração de convênios e contratos entre a SPU e os Estados, Municípios e mesmo com a iniciativa privada que, inclusive, fará jus a parte das respectivas receitas.

179 Cf. supra 1.3.1. 
Há que se ressaltar a especial importância de tais avenças, para os Municípios desprovidos de recursos e quadros qualificados ${ }^{180}$, não se olvidando dos instrumentos postos à disposição do Município pelo art. $4^{\circ}$ da Lei $n^{\circ} 10.257$, de 10.07.2001.

Desta forma, o Município terá condições de enfrentar as atribuições decorrentes da consolidação da área na sua esfera, no caso de extinção do terreno de marinha, sem que a eliminação do referido instituto resulte na instituição de novo tributo.

Importante ressaltar, ainda, que o projeto Orla ${ }^{181}$ prevê uma metodologia de treinamento de gestores locais para cada Município selecionado, voltada à elaboração de um Plano de Intervenção da Orla Marítima ${ }^{182}$, com base no reconhecimento das características naturais, nos tipos de uso e ocupação existentes e projetados.

Após o treinamento e a elaboração do mencionado Plano de Intervenção, o Município estará habilitado a celebrar um Convênio com a SPU, assumindo as tarefas de fiscalização e gerenciamento do uso e ocupação da orla marítima (incluindo os terrenos de marinha), originariamente de competência daquela Secretaria recebendo em até $50 \%$ dos recursos

180 Em 2012 foram realizados 3 cursos regionais (nas cidades do Rio de Janeiro, Recife e Fortaleza), capacitando 150 instrutores em 17 Estados Costeiros. Esses cursos formaram instrutores capazes de atuar na gestão da orla brasileira, orientando e facilitando processos de elaboração de Planos de Gestão Integrado do Projeto Orla. Ministério do Meio Ambiente 2013 - Secretaria de Extrativismo e Desenvolvimento Rural Sustentável. Departamento de Zoneamento Territorial. Gerência Costeira Relatório de Gestão / Gerência Costeira 2011-2012.

181 Cf. supra, 1.3.1.

182 Síntese das atribuições da Coordenação Municipal do Projeto Orla: formular proposta de adesão ao Projeto Orla junto à Coordenação Estadual (OEMA - Órgãos Estaduais de Meio Ambiente e GRPU - Gerências Regionais do Patrimônio da União), por meio da Ficha de Adesão; elaborar agenda de atividades para o Projeto, incluindo reuniões preliminares com OEMA e GRPU; apresentar e justificar a composição preliminar do grupo de atores a ser capacitado; organizar e listar documentos técnicos, cartográficos, base legal e logística para realização da oficina de capacitação no município; elaborar o Plano de Gestão Integrada da Orla; convocar audiências públicas para legitimação do Plano de Gestão Integrada, da composição do Comitê Gestor da Orla, dos projetos e das ações; criar o Comitê Gestor da Orla; propor a celebração de convênios; analisar a base legal e os instrumentos necessários à celebração de futuros convênios; coordenar a execução das ações propostas no Plano de Gestão Integrada. 
foreiros. ${ }^{183}$

Assim, o Município, enquanto guardião do interesse local, passa a atuar de forma mais eficaz na solução de problemas como a ocupação irregular de terrenos da União, expansão desordenada do turismo, implementação da carcinicultura em áreas impróprias, falta de saneamento básico e erosão.

Nesse sentido, um dos objetivos do Projeto Orla é precisamente acelerar a implantação de cessão patrimonial para os Municípios, com a contrapartida de que a gestão da Orla Marítima seja feita de forma compatível com o conceito de patrimônio coletivo. ${ }^{184}$

183 No Estado de São Paulo poucos municípios aderiram ao Projeto, como Ubatuba e Guarujá. Neste, além do Projeto Orla, constituído em janeiro de 2012, a Agenda 21 instituiu um Fórum Permanente tripartite, com a participação de organizações da sociedade civil (terceiro setor), setor produtivo (segundo setor) e governo (primeiro setor), elaborando um Plano de Desenvolvimento Sustentável para o Guarujá intitulado "Guarujá 2034". Todavia, a qualificação e capacitação dos representantes constitui desafio a ser equacionado, a fim de que os Conselhos possam exercer efetivamente o seu papel, à vista da assimetria de conhecimento e informação entre os representantes da sociedade civil oriundos de comunidades e os representantes do poder público e do setor produtivo, detentores de mais informações e conhecimento. O Comitê Gestor do Projeto Orla tem como objetivo compatibilizar as políticas ambientais e patrimoniais no trato dos espaços litorâneos. Pelo Poder Público Federal é representado pela Secretaria de Patrimônio da União - SPU e IBAMA, o Estado pela Secretaria do Meio Ambiente e a Fundação Florestal - APA Marinha e a Prefeitura pelas Secretarias Municipais de Turismo, Meio Ambiente, Desenvolvimento e Gestão Urbana, Advocacia Geral do Município, Executiva de Coordenação Governamental, Cultura, Educação, Planejamento Estratégico e Esportes e Lazer. A Sociedade Civil é representada pela Associação Eco-praias dos Ambulantes das praias de Guarujá, Associação da Orla do Guarujá - restaurantes/bares/quiosques, Associação dos Quiosques da Praia do Tombo, Associação dos Pescadores Artesanais do Canal de Bertioga (Unipesc), Sociedade de Amigos da Praia do Guaiúba, Associação Sítio Conceiçãozinha, Instituto Socioambiental - ISSA, Sociedade Amigos da Praia Branca - Comunidade Tradicional, Associação Esportiva - Liga de Esporte de Areia, UNAERP, Associação de Surf do Guarujá, Agenda 21 local (Diagnóstico Urbano Socioambiental - Município do Guarujá - Convênio Petrobras Instituto Polis - Relatório nº 6 - Base das Informações até 2012 - revisão de março de 2013, p. 45-61).

184 Gilberto Huet de Bacellar Sobrinho, Decreto presidencial regulamenta o uso e a ocupação da zona costeira e estabelece os critérios para a Gestão da Orla Marítima, in Gestão Costeira Integrada, ㄲo 5, ano 4, 2006, p. 06-09. O autor foi relator do Grupo de Trabalho instituído no âmbito da CIRM que elaborou a minuta do Decreto o $5.300 / 2004$, alude ao treinamento da Secretaria Estadual do Meio Ambiente do Estado do Rio de Janeiro promovido em 2004 realizado com municípios do Estado, dos quais quatro já celebraram convênio com a SPU, Quissamã, Macaé, Rio das Ostras e Armação de Búzios, voltados à fiscalização e ao gerenciamento do uso e ocupação da Orla Marítima. 
Ao tratar da gestão na zona costeira, CONSTANÇA DE CARVALHO BELCHIOR lembra que uma governança adequada para lidar com as questões costeiras e capaz de assegurar um processo de Gerenciamento Costeiro Integrado, só poderá existir se o público afetado estiver envolvido ativamente no processo. "A participação dos stakeholders desde o início das discussões e na elaboração do programa vai garantir que o conhecimento local e as aspirações do público sejam incorporados neste, de tal modo que as questões focadas e os objetivos traçados sejam adequados à realidade. Isto fará com que os benefícios obtidos correspondam às expectativas da população, garantindo assim uma adesão da sociedade ao programa, vital para o seu sucesso e continuação.

O envolvimento do público passa, não apenas por uma participação no processo de tomada de decisão, mas também por uma adequada informação, pois as causas subjacentes do estado atual das zonas costeiras são complexas e muitas vezes incompreendidas pelo público e pelos tomadores de decisão. Sem esse conhecimento, a gravidade da situação nunca será tratada de modo adequado, nem criará mobilização social para a resolução dos problemas. De resto, sem esta mobilização, a vontade política para tomar decisões geralmente controversas e com algum custo político dificilmente existirá." 185

Conclui-se que a correta informação do munícipe também é essencial para derrubar barreiras como inércia burocrática, desconfiança, oposição ideológica ou oposição devida a interesses econômicos. A participação popular em audiências e consultas públicas sem adequada informação, inclusive técnica, constitui meio fraudulento de legitimação do processo decisório.

185 Cit, p. $48-49$. 
Imprescindível, portanto, o maior nível possível de envolvimento dos stakeholders envolvidos no gerenciamento do desenvolvimento costeiro, tais como marinha e setor de defesa, atividade portuária e naval, turismo e lazer, comércio e atividade pesqueira, controle de erosão, poluição das águas e ecossistemas costeiros, atividade petrolífera e mineral, energia, transporte, urbanização e moradia. Outrossim, a participação é um imperativo para que a pessoa seja sujeito e não objeto do desenvolvimento, fazendo assim, sua própria história. ${ }^{186}$

Em breve incursão ao direito francês, verifica-se que o art. L. 146-4 III da Lei de 03.01.1986, proíbe construções a $100 \mathrm{~m}$ da banda litorânea, exceção feita aos espaços urbanos e às construções ou instalações necessárias aos serviços públicos ou às atividades econômicas que exigem a proximidade da água, como uma peixaria, um viveiro de pescados, uma oficina de reparação de embarcações, conforme informa JACQUELINE MORAND-DEVILLER. ${ }^{187}$ Em outro estudo, ${ }^{188}$ a mesma autora comenta os dispositivos da referida lei, indagando sobre a existência de um direito 'específico do litoral' e à dificuldade de se definir a noção de 'espaços urbanizados'. 189

186 Ver John R. Clark, cit, p. 47.

187 Droit de l'urbanisme, 3 ed., Paris Dalloz, 1996, p. 30-31. Sobre o assunto, conferir também Drobenko, aludindo à vedação da criação de vias de tráfego a menos de $2.000 \mathrm{~m}$ da orla, bem como em praias e dunas, excepcionando equipamentos, infraestruturas e obras necessárias à segurança (civil, marítima e aérea), situações sujeitas à apreciação judicial de sua necessidade técnica, salientando que portos de lazer não se incluem nessas exceções (Droit de l'urbanisme, 2 ed., Paris, Gualine, 2005, p. 79-82).

188 L'environnement et le droit, LGDJ, Paris, 2001, p. 46-47.

189 Outros aspectos relevantes da lei também são abordados por Bernard Drobenko. Em linhas gerais, o texto procura conciliar as preocupações econômicas, notadamente o turismo e as atividades específicas do litoral como a pesca, os portos e o laser, com o desenvolvimento urbano e a qualidade ambiental. A coordenação das ações públicas nos espaços litorâneos fica a cargo do Conselho Nacional do Mar e do Litoral, presidido pelo Primeiro Ministro, competente para o estabelecimento das diretrizes relativas ao domínio público marítimo (Droit de l'urbanisme, p. 76).

Formatado: Fonte: 10 pt, Português (Brasil)

Formatado: Fonte: 10 pt, Português (Brasil)

Formatado: Fonte: 10 pt, Português (Brasil) 
O direito francês apresenta ainda interessantes experiências no gerenciamento da orla marítima pela esfera local. RAPHAEL ROMI ${ }^{190}$ destaca a experiência francesa dos Conselhos da Orla, composto por membros eleitos pela comunidade para um mandato renovável de três anos, em número de cinco: Conselho Mediterrâneo, Atlântico, Mar do Norte, dos Lagos e da Córsega. BERNARD DROBENKO ${ }^{191}$ ressalta a importância da participação popular na gestão do que denomina 'espaços litorâneos sensíveis'.

Ressalta-se aqui que a participação da comunidade envolvida no processo de tomada de decisões confere maior eficácia ao controle social da Administração, legitimando-o e institucionalizando-o, porquanto aderente às instâncias mais próximas do locus decisório, invariavelmente representado pelo Município, quando contraposto ao distante trato com a União, titular do domínio dos terrenos de marinha.

Todavia, há que se ressaltar que referida participação permanece em estado germinal, seja em razão dos sucessivos ciclos autoritários da história brasileira ou das dificuldades de sua absorção na cultura brasileira, ainda dependente da atuação estatal, não obstante a existência de expressivo instrumental legal.

Há que se atentar, por outra via, ao risco da adoção de tais mecanismos, ao constituir instâncias deliberatórias com a participação de membros da sociedade, servir de meio para diluir a responsabilidade do administrador ou emperrar a atividade administrativa.

190 Domat - Droit public. Droit et administration de l'environement. Paris, Montchrestien, 1997, p. 222. 191 Droit de l'urbanisme, p. 81. 
Como bem ponderado por ODETE MEDAUAR: "Discute-se também, quanto ao bloqueio na tomada de decisões e na atividade administrativa trazido pela extensão participativa; haveria emperramento da máquina, sobretudo ante a polisinódia, ou seja, a criação ad infinitum de conselhos, comissões, grupos de trabalho; além disso, ocorreria diluição da responsabilidade do administrador ou justificativa para ausência de atuação. Na verdade, parece inviável vincular toda a atividade administrativa à participação direta de particulares; igualmente sob esse ângulo sobressai a importância de fixar preceitos básicos e pesquisar meios de conciliação de presteza com participação". ${ }^{192}$

Seja como for, esse contexto demonstra a mudança de paradigma no direito administrativo contemporâneo, até então centrado na unilateralidade do ato administrativo em sua visão tradicional, para a atuação da administração via processo/consenso e, portanto, participação social. Todavia a análise desse fenômeno foge aos estreitos limites deste trabalho. ${ }^{193}$

Outro aspecto a ser enfrentado é a falsa ideia de que o bem público cumpriria sua função social apenas por pertencer ao domínio público, devendo sua utilização de dar de forma eficiente.

192 O direito administrativo em evolução, 2 ed., São Paulo, Revista dos Tribunais, 2003, p. 220.

193 Vide a esse propósito: "A superação do ato administrativo autista", Floriano de Azevedo Marques Neto, p. 89-113; "Como a teoria do ato administrativo pode ser aproveitada na prática da consensualidade?", Juliana Bonacorsi de Palma, 237-261, in Os caminhos do ato administrativo, Odete Medauar e Vitor Rhein Schirato (Coord.), São Paulo, Revista dos Tribunais, 2011; Atuais rumos do processo administrativo, Odete Medauar e Vitor Schirato (org.), São Paulo, Revista dos Tribunais, 2010; A processualidade no direito administrativo, 2 ed., Odete Medauar, São Paulo, Revista dos Tribunais, 2008. 
É o que preleciona FLORIANO DE AZEVEDO MARQUES NETO ${ }^{194}$, afastando a condição de bem público no sentido dado pelos economistas, permitindo o emprego eficiente deste bem, assegurando a efetividade de políticas públicas: "Em compasso com o exposto, refutamos a tese de que o bem público cumpriria sua função social por pertencer ao domínio do ente público. Além da pertença do bem ao domínio público não ser garantia da melhor utilidade possível, o bem desse jaez poderá deixar de cumprir sua função social se se quedar inutilizado no patrimônio público. Apenas se todas as possibilidade de uso forem aproveitadas quando do emprego do bem, vimos, haverá cumprimento da função social da propriedade, função esta que se mostrará mais incisiva em relação aos bens do Estado, uma vez que a propriedade estatal se fundamenta na aplicação eficiente dos bens à função pública. Embora a finalidade seja a nota peculiar e distintiva dos bens públicos em relação aos bens privados, verificamos inexistirem antagonismos entre os regimes patrimoniais público e privado, pois a Administração deve gerir seus bens nos moldes do particular eficiente, desde que isto não inviabilize as finalidades primárias do bem público".

Convém também alertar que, em relação ao interesse local, o abandono do aforamento como forma de utilização dos terrenos de marinha, deixa ao desabrigo o interesse da municipalidade, uma vez que a ocupação não exige audiência prévia dos entes locais, instrumento que tem por escopo auscultar os interesses e projetos relativos aos terrenos de marinha. Não havendo audiência prévia, a Municipalidade não toma conhecimento, o que dificulta os seus projetos urbanísticos.

194 O regime jurídico das utilidades públicas, p. 551. 
Além da impossibilidade de se definir os exatos limites de tais terrenos, conforme já verificado, outra consequência é a impossibilidade de desapropriação do terreno ocupado, pois não há desmembramento do domínio, permanecendo íntegro em mãos da União que não pode ser desapropriada pelo Município.

Destarte, a prevalecer o emprego do instituto da ocupação, deverá o mesmo prever audiência obrigatória das Municipalidades para defesa dos interesses locais, bem como conceder-lhe direito de opção por ocasião das transferências onerosas de ocupação, caso a União não o exerça na sistemática atual.

Portanto, a manutenção do instituto do terreno de marinha não só é desnecessária, como a sua limitação aos 33 metros carece de fundamento científico, além de ser insuficiente para o atendimento de quaisquer das justificativas de sua manutenção, não se olvidando dos problemas advindos do recolhimento do foro, laudêmio e taxa de ocupação e da manifestação prévia da desaparelhada SPU em cada transmissão inter vivos.

Na presente data, duas Propostas de Emenda à Constituição tramitam no Senado Federal, pugnando pela extinção do instituto do terreno de marinha e seus acrescidos.

A primeira, de autoria do Senador Almeida Lima - PEC 53 de 06.06.2007, propõe a revogação do inc. VII do art. 20 da Constituição Federal e do $\S 3^{\circ}$ do art. 49 do ADCT, para 
extinguir o instituto do terreno de marinha e seus acrescidos e para dispor sobre a propriedade desses imóveis.

A PEC $n^{\circ} 53$ apresenta quatro artigos: o art. $1^{\circ}$ extingue o instituto do terreno de marinha e seus acrescidos; o art. $3^{\circ}$ estabelece a vigência da inovação constitucional em 120 dias a contar de sua publicação, e o art. $4^{\circ}$ revoga o inc. VII do art. 20 da Constituição Federal e o $\S$ $3^{\circ}$ do art. 49 do ADCT.

$\mathrm{O}$ art. $2^{\circ}$ da PEC $\mathrm{n}^{\circ} 53$ contém a essência da proposta: continuam no domínio da União as áreas nas quais tenham sido edificados prédios públicos que abriguem órgãos ou entidades da administração federal, inclusive instalações de faróis de sinalização náutica e as que tenham sido regularmente destinadas à utilização por prestadores de serviços públicos concedidos ou permitidos pela União; o mesmo se dá com áreas transferidas ao mesmo título para os Estados, Municípios e as que estejam locadas ou arrendadas a terceiros pela União; as áreas doadas mediante lei federal continuam sob domínio pleno aos respectivos donatários; ao domínio pleno dos foreiros, quites com suas obrigações, as áreas sob seu domínio útil, mediante contrato de aforamento, bem como ao domínio pleno dos cessionários aquelas cedidas pela União.

Em trâmite conjunto, a PEC n 56, de 16.12.2009, de autoria do Senador Marcelo Crivella, acrescenta o art. 97 ao ADCT, para que seja autorizado à União proceder à transferência do domínio pleno dos terrenos de marinha e seus acrescidos, nos termos do inc. VII do art. 20 da Constituição Federal, aos foreiros, ocupantes, arrendatários e cessionários, mediante 
pagamento de valor equivalente à parcela do domínio detida pelo Poder Público, nos termos da lei.

O parágrafo único confere à lei que disciplinar a transferência do domínio pleno dos terrenos de marinha, estipular o prazo de até cinco anos para a União adotar as medidas administrativas necessárias à efetiva transferência do domínio pleno dos referidos terrenos aos novos proprietários, ressalvados os terrenos de interesse público (imóveis utilizados pela União, Estados e Municípios, ou essenciais à segurança nacional, como as instalações militares).

Dessa forma, estaria consolidada a propriedade dos referidos bens na esfera patrimonial dos ocupantes, entendendo que deverá ocorrer sem imposição de ônus. Nesse sentido entende-se desnecessário o pagamento estipulado pela $\operatorname{PEC~} \mathrm{n}^{\circ} 56$, bastando que o foreiro esteja quite com as obrigações (isentos ocupantes, arrendatários e cessionários) de acordo com a PEC n ${ }^{\circ}$ 53 e sem necessidade de qualquer regime de transição legal, bem como despiciendo o prazo de 5 anos aludido pela $\operatorname{PEC~} n^{\circ} 56$, bastando os 120 dias preconizado pela $\mathrm{PEC} \mathrm{n}^{\circ} 53$.

Em 13.05.2008 foi realizada audiência pública para instrução da matéria, com a participação de, somente, 10 (dez) convidados.

De acordo com os registros disponíveis no sítio do Senado Federal, em 03.09.2013, o relatório do Senador Ricardo Ferraço foi recebido na Comissão de Constituição e Justiça, com voto 
contrário à PEC no 56/2009, e favorável à PEC n 53/2007, na forma do substitutivo apresentado. $^{195}$

195 A relevância de eventual aprovação da PEC para o objeto deste trabalho justifica a sua transcrição integral. Este é o teor do substitutivo do Senador Ricardo Ferraço em 03.09.2013:

Art. 1ํO inciso VII do Art. 20, da Constituição Federal, passa a ter a seguinte redação:

"VII - terrenos de marinha e seus acrescidos mantidos sob seu domínio;"

Art. $2^{\circ}$ As áreas de terrenos de marinha e seus acrescidos passam a ter a sua propriedade assim definida:

I - continuam como domínio da União as áreas: a) nas quais tenham sido edificados prédios públicos que abriguem órgãos ou entidades da administração federal, inclusive instalações de faróis de sinalização náutica; b) que tenham sido destinadas à utilização por prestadores de serviços públicos concedidos ou permitidos pela União; c) destinadas ao adestramento das Forças Armadas ou que sejam de interesse público, nos termos da lei; d) de restinga, fixadoras de dunas ou estabilizadoras de mangues;

II - passam ao domínio pleno dos Estados onde estão situadas as áreas: a) nas quais tenham sido edificados prédios públicos que abriguem órgãos ou entidades da administração estadual; b) que tenham sido destinadas à utilização por prestadores de serviços públicos concedidos ou permitidos pelos respectivos Estados;

III - passam ao domínio pleno dos Municípios onde estão situadas as áreas: a) nas quais tenham sido edificados prédios públicos que abriguem órgãos ou entidades da administração municipal; b) não enquadráveis nas hipóteses descritas nos incisos I e II e incisos IV e V deste artigo; c) que tenham sido destinadas à utilização por prestadores de serviços públicos concedidos ou permitidos pelos respectivos Municípios; d) atualmente locadas ou arrendadas a terceiros pela União.

IV - permanecem sob domínio pleno dos respectivos donatários as áreas doadas mediante autorização em lei federal;

$V$ - passam ao domínio pleno: a) dos foreiros, quites com suas obrigações, as áreas sob domínio útil destes, mediante contratos de aforamento; b) dos ocupantes atualmente inscritos no órgão administrador do patrimônio da União, quites com suas obrigações, as áreas por eles ocupadas; c) dos atuais ocupantes, ainda não inscritos no órgão administrador do patrimônio da União, desde que promovam suas inscrições, no prazo de um (1) ano, a contar da data da vigência desta Emenda Constitucional, as áreas por eles ocupadas; d) dos cessionários, as áreas que lhes foram cedidas pela União; e) dos respectivos ocupantes, as áreas de aldeamentos indígenas e quilombos, independentemente de cumprimento de qualquer formalidade legal ou de quitação de débitos;

$\S 11^{\circ}$ - Os Municípios que, por força desta Emenda Constitucional, adquirirem o domínio pleno de áreas atualmente ocupadas por brasileiros, ainda não inscritos no órgão administrador do patrimônio da União e que não promoverem suas inscrições no prazo previsto na alínea " $c$ " do inciso $V$, ficam obrigados a lhes transferir o domínio pleno dessas áreas, desde que comprovada a posse e por esses ocupantes requerido, no prazo de cinco (5) anos, a partir da vigência desta Emenda Constitucional.

$\S 2$ - Ao oficial do registro imobiliário da circunscrição respectiva, à vista das certidões de quitação das obrigações relativas ao imóvel, quando exigível, cumpre proceder ao registro da transmissão do domínio pleno em favor das pessoas referidas nos incisos II a V e $\S 1^{\circ}$ deste artigo. 
O Relator reconhece a relevância da matéria, estribado nos seguintes argumentos: o evidente anacronismo do instituto; a extinção da enfiteuse no âmbito do direito civil; a ausência de adequada identificação e demarcação até os dias de hoje, gerando insegurança jurídica e inesperados encargos financeiros para significativa parcela de seus ocupantes; ínfima rentabilidade da manutenção do instituto, cuja arrecadação a título de taxa de ocupação, foro, laudêmio e multas, representa cerca de $0,01 \%$ (um centésimo por cento) da receita tributária da União; entraves e insegurança para o adequado desenvolvimento da zona costeira, inclusive impedindo que essas áreas possam servir de garantia a financiamentos para construção de residências.

Justifica a rejeição da PEC no 56/2009, em razão da utilização de técnica legislativa inadequada, ao propor acréscimo de artigo no Ato das Disposições Constitucionais Transitórias, que tinha o objetivo a regulamentação de assuntos atinentes à transição da ordem

Art. 3o A identificação e demarcação dos terrenos de marinha e acrescidos, nos termos da legislação em vigor, continuará a ser realizada pela União, através de órgão próprio, pelo prazo de cinco (5) anos, a contar da vigência desta Emenda.

$\S 11^{\circ}$ - Esgotado o prazo previsto no "caput", compete aos municípios onde se situam as respectivas áreas, a identificação e demarcação dos terrenos de marinha e acrescidos, pelo prazo consecutivo de cinco (5) anos.

$\S 2^{\circ}$ - As áreas de terrenos de marinha e acrescidos que não tenham sido identificadas e demarcadas, nos prazos previstos no "caput" desta artigo e seu $\S 1^{\circ}$, passarão a ser consideradas como devolutas, para efeito de regularização fundiária pelos respectivos ocupantes.

Art. 4ํ Ficam remidos os débitos referentes a foro, taxa de ocupação, laudêmio, multa, juros e quaisquer outros decorrentes da legislação sobre terrenos de marinha e acrescidos, com relação aos imóveis exclusivamente residenciais.

Art. 5 Para fins de definição de áreas de marinha e acrescidos, consideram-se legítimos todos os títulos de propriedade lançados no registro imobiliário até a data da vigência desta Emenda.

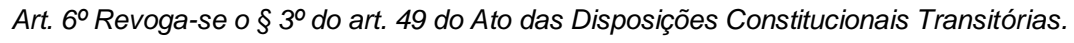

Art. $7^{\circ}$ Esta Emenda Constitucional entra em vigor na data de sua publicação. 
constitucional anterior para a nova. Quanto ao mérito, a PEC n ${ }^{\circ} 56 / 2009$ deve ser rejeitada, pois prevê que foreiros, ocupantes, arrendatários e cessionários paguem pela aquisição do domínio pleno dos terrenos de marinha, contrapartida esta já efetuada ao longo de décadas.

Em relação à $\mathrm{PEC} \mathrm{n}^{\circ}$ 53/2007, da forma como redigida, exige alterações, porquanto: cria perigoso ‘vazio jurídico' com a pura e simples extinção do instituto, pois grande parte dos terrenos de marinha e acrescidos ainda não foi objeto de identificação e demarcação, mantendo-se sob o domínio da União tão somente as áreas que lhe foram reservadas nesta Emenda Constitucional. Ademais, transfere ao domínio dos Municípios as áreas em regime de ocupação, invariavelmente na pose de pessoas muito simples, de baixo nível de escolaridade, de pequeno poder aquisitivo, tais como os aldeamentos indígenas e antigos quilombos que também não são contemplados por qualquer norma específica. Outrossim, não há menção às áreas de restinga fixadoras de dunas ou estabilizadoras de mangues, de preservação permanente.

O substitutivo apresentado avança em relação às propostas originais, exceto quanto à desnecessária manutenção do instituto a fim de se evitar o alegado 'vazio jurídico', porquanto a atribuição ao domínio da União das áreas que lhe foram reservadas prescinde da permanência do instituto no texto constitucional. 


\subsection{O papel do Município no sistema urbanístico}

A par da consolidação dos terrenos de marinha e acrescidos na esfera municipal, a promoção do interesse local pelo Município na zona costeira urbana ocorre por meio do Plano Nacional de Gerenciamento Costeiro II, em especial pela sua inserção no Projeto Orla, bem como pelo manejo de um sem número de instrumentos urbanísticos entre os quais se destaca o plano diretor.

O art. 182 da Constituição Federal constitui a base constitucional sobre a qual está erigido o sistema urbanístico brasileiro, ao estabelecer as diretrizes ${ }^{196}$ da política de desenvolvimento urbano a ser executada pelo Município, conforme diretrizes gerais fixadas em lei (especialmente a Lei $\mathrm{n}^{\mathrm{o}}$ 10.257, de 10.07.2001), com o objetivo de ordenar o pleno desenvolvimento das funções sociais da cidade $^{197}$ (habitar, recrear, trabalhar e circular) e garantir o bem estar de seus habitantes.

196 Odete Medauar, lembra que "no vernáculo, a palavra diretrizes denota o sentido de: linhas reguladoras; instruções ou indicações para se realizar um plano ou uma ação; orientação; linhas básicas; balizas; esquemas gerais. Ainda surge como sinônimo de diretivas. Transposta para a fonte legislativa significa preceitos indicadores, preceitos que fixam esquemas gerais, linhas básicas, balizas em determinadas matérias; preceitos norteadores da efetivação de uma política. Tais prescrições norteadoras dirigem-se, em tese, a outros legisladores, a administradores ou ao intérprete em geral" (A força vinculante das diretrizes da política urbana, Revista Jurídica da Procuradoria Geral do Município de São Paulo, n. 6, São Paulo: CEJUR, mar. 2008, p. 53).

197 José Roberto Castilho chama atenção ao caráter tautológico ou redundante da expressão 'função social da cidade', vez que o fenômeno urbano é necessariamente coletivo ou social ( $O$ plano local no direito urbanístico brasileiro e comparado - Tese de Doutorado USP/1997, p. 150). Preveem os urbanistas funções sociais genéricas, como bem salientam Carlos Alberto Dabus Maluf e Adriana Caldas do Rego Freitas Dabus Maluf: "Entre as funções sociais da cidade destacam-se a habitação, o trabalho, a circulação, o lazer, visando a plena integração dos seres humanos, seu crescimento educacional e cultural, em um ambiente sustentável e ecologicamente equilibrado" (Comentários ao estatuto da cidade, São Paulo, Atlas, 2010, p. 22). 
São normas gerais urbanísticas as pertinentes à utilização da propriedade urbana, as referentes à ação integrada de organismos federais, estaduais e municipais sobre o desenvolvimento urbano, as diretrizes sobre as áreas de interesse especial, planejamento urbanístico, instrumentos de intervenção urbanística e as bases do regime urbanístico do solo.

Aos Estados cabe dispor sobre normas urbanísticas regionais (normas de ordenação do território estadual), suplementares das normas gerais estabelecidas pela União (art. 24, I); o plano urbanístico estadual (plano de ordenação do território do estado), e planos urbanísticos regionais (planos de ordenação territorial de região estabelecida pelo Estado, que podem ter natureza de planos de coordenação urbanística na área); instituir e disciplinar as regiões metropolitanas, microrregiões e aglomerações urbanas; servir como elo entre os planos federais e municipais, restando limitado o conteúdo de sua atuação entre a generalidade do federal e a especificidade do municipal.

Aos Municípios cabe estabelecer a política de desenvolvimento urbano, com o objetivo de ordenar o pleno desenvolvimento das funções sociais da cidade; garantir o bem-estar de seus habitantes (art. 182); promover o adequado ordenamento de seu território, mediante o planejamento e o controle do uso, do parcelamento e da ocupação do solo urbano, elaborando e executando, para tanto, o plano diretor (art. 30, VIII).

É importante ressaltar que a competência municipal não é meramente suplementar de normas gerais federais ou de normas estaduais, pois não são criadas com fundamento no art. 30, II, tratando-se competência própria emanada do texto constitucional. A função urbanística, em 
sua atuação mais concreta e eficaz, é exercida no nível municipal, origem dos planos de desenvolvimento urbano, que estabeleciam regras para o desenvolvimento físico das cidades, vilas e outros núcleos urbanos do Município.

A respeito do planejamento urbanístico, JOSÉ AFONSO DA SILVA observa: “Tem-se aí, duas amplas perspectivas básicas do planejamento e desenvolvimento urbano: uma que tenha como objeto o desenvolvimento adequado da rede urbana (planejamento interurbano) no nível nacional $^{198}$, regional e estadual; outra que considere o desenvolvimento urbano no quadro do território municipal (planejamento intraurbano ou intramunicipal), no nível local (...) O aspecto econômico do sistema deverá ser mais intenso em nível nacional, tornando-se menor nos escalões inferiores até o nível local; em contrapartida, o aspecto da ordenação físicoterritorial há de ser mais concreto e eficaz no nível local e mais geral nos escalões superiores até o de simples diretrizes em nível nacional". ${ }^{199}$

Assim, enquanto o plano nacional prepondera no aspecto econômico, as normas urbanísticas municipais são as mais características ${ }^{200}$, porque nos Municípios se manifesta a atividade urbanística na sua forma mais concreta e dinâmica, ${ }^{201}$ observadas diretrizes e objetivos gerais

198 O art. $3^{\circ}$ da Lei № 10.257, de 10.07.2001 trata das competências da União para com a administração da política urbana.

199 Direito urbanístico brasileiro, 6 ed., São Paulo, Malheiros, 2010, p. 98-102.

200 Cf. supra 1.2 .2 e 2.1 .

201 O processo de planejamento permanente do Município realiza-se pela elaboração, manutenção atualizada e execução de: I - um plano de desenvolvimento municipal, que é o plano de governo, pelo qual cada prefeito definirá as prioridades e objetivos de seu governo em função da realidade local; II os planos regionais, setoriais e especiais, que couberem; III - o plano diretor, como instrumento básico da política de desenvolvimento urbano, e os demais planos urbanísticos (particulares, parciais, especiais ou setoriais) exigidos pela realidade local; IV - o plano plurianual, que define, em consonância com o plano de governo e o plano diretor, as diretrizes, objetivos e metas da Administração Municipal; V - a lei de diretrizes orçamentárias, que, incluindo as despesas de capital 
do desenvolvimento urbano estabelecidos pela União, bem como regras genéricas de coordenação expedidas pelo Estado.

Ao chamar atenção ao plano local e, portanto, mais próximo de uma concreção que possibilite maior participação social e resultados com presumida eficácia, MARIA PAULA DALLARI $\mathrm{BUCCI}^{202}$ ressalta o aspecto democrático do processo: “A realização do processo democrático na gestão das cidades é a razão da própria existência do Estatuto da Cidade, que resulta, ele próprio, de uma longa história de participação popular, iniciada na década de 80 , e que teve grande influência na redação do capítulo da política urbana da Constituição Federal. A plena realização da gestão democrática é, na verdade, a única garantia de que os instrumentos de política urbana introduzidos, regulamentados ou sistematizados pelo Estatuto da Cidade (tais como o direito de preempção, o direito de construir, as operações consorciadas, etc.) não serão meras ferramentas a serviço de concepções tecnocráticas, mas, ao contrário, verdadeiros instrumentos de promoção do direito à cidade para todos, sem exclusões".

Há, contudo, longo caminho a ser percorrido para a efetiva implantação de uma gestão democrática das cidades, não obstante ofereça o referido Estatuto inúmeros instrumentos que, se bem manuseados, possibilitam o desenvolvimento sustentável do ambiente urbano e a observância da função social da propriedade urbana referida no art. 182 da Lei Maior.

para o exercício financeiro subsequente, definirá, em termos financeiros, as metas e as prioridades do governo local, orientará a elaboração do orçamento anual e disporá sobre as alterações na legislação tributária, se tais alterações houverem que ser feitas; VI - o orçamento anual. Todos esses planos deverão ser compatíveis entre si e seguir as políticas gerais e setoriais segundo as quais o Município organiza sua ação (Idem, p. 134-135).

202 Gestão democrática da cidade, in Adilson Abreu Dallari e Sérgio Ferraz, Estatuto da cidade, p. 335-354. 
A opção do constituinte, em relegar a definição material da função social da propriedade ao Município, é questionada por FERNANDO DIAS MENEZES DE ALMEIDA: "Causa estranheza essa opção do constituinte. Seria perfeitamente cabível, e mesmo recomendável, que houvesse uma definição material de abrangência nacional quanto à função social da propriedade urbana, com um enfoque geral que independesse das especificidades de cada Município.

Não se nega ser razoável a Constituição permitir que cada plano diretor estabeleça as exigências fundamentais de ordenação da cidade, direcionando assim o modo de atendimento da função social da propriedade urbana de acordo com a realidade local. Porém, isso não seria incompatível com uma definição constitucional das linhas gerais a serem seguidas pelos Municípios nesse mister. Aliás, tal foi a postura adotada pelo constituinte ao definir, no art. 186, caput, sem prejuízo de regulamentação por lei, os requisitos para o atendimento da função social da propriedade rural.

De todo modo, uma leitura combinada do citado $\S 2^{\circ}$ com o $\S 4^{\circ}$ do mesmo art. 182 da Constituição permite que se infira ao menos um aspecto material da concepção do constituinte acerca da função social da propriedade urbana: o solo urbano não cumpre sua função social se não utilizado, subutilizado ou não edificado". ${ }^{203}$

203 Dos instrumentos da política urbana, in Odete Medauar e Fernando Dias Menezes de Almeida (Cord.), Estatuto da cidade, São Paulo, Revista dos Tribunais, 2004, p. 41-119. 
Assim sendo, pelo manejo dos instrumentos previstos no art. $4^{\circ}$ da Lei $n^{\circ} 10.257$, de 10.07.2001, os Municípios poderão efetivar o interesse local na zona costeira, em especial aqueles de pequeno porte desprovidos de recursos.

FERNANDO DIAS MENEZES DE ALMEIDA ${ }^{204}$ critica a sistematização do art. $4^{\circ}$, porquanto utilizada em sentido muito amplo e heterogêneo, pautados em critérios de precária logicidade: "Sob essa rubrica são englobados elementos muitos diversos e dificilmente comparáveis entre si: uns mais amplos (exemplo: plano nacional de desenvolvimento econômico e social, plano diretor), outros mais restritos (exemplo: tombamento e concessão de direito real de uso); uns envolvendo conceitos jurídicos abstratos (exemplo: limitações administrativas e direito de superfície), outros envolvendo elementos de fato (exemplo: gestão orçamentária participativa); uns enunciados como o objeto em si (exemplo: desapropriação e plano plurianual), outros enunciados como uma ação que se refere ao objeto (exemplo: instituição de unidade de conservação e instituição de zonas especiais de interesse social)".

ADILSON ABREU DALLARI ${ }^{205}$ distingue instrumentos de planejamento situados fundamentalmente no plano físico, destinado a disciplinar os espaços urbanos (plano diretor, disciplina do parcelamento, uso e ocupação do solo e zoneamento ambiental), daqueles basicamente econômicos, destinados à disciplina do uso dos recursos financeiros municipais (plano plurianual, diretrizes orçamentárias e o orçamento anual).

204 ldem, p. 43.

205 Instrumentos da política urbana, in Adilson de Abreu Dallari e Sérgio Ferraz, Estatuto da cidade, p. 71-86. 
O exame aprofundado de cada um dos instrumentos previstos no art. $4^{\circ}$ e seguintes da Lei $n^{\circ}$ 10.257, de 10.07.2001 foge ao propósito deste trabalho.

Destarte, a análise se restringe ao plano diretor ${ }^{206}$, elemento basilar da política de sistematização do desenvolvimento físico, econômico e social urbano, da disciplina do uso e ocupação do solo, bem como do exercício de atividades desenvolvidas no município ${ }^{207}$, reafirmando ser o plano local o mais apto à aferição de sua vocação econômica e social.

O delineamento da referida vocação deve estar sujeito à ratificação da comunidade $^{208}$, assegurada a gestão democrática da cidade por meio do estabelecimento de órgãos colegiados de política urbana, da realização de debates, audiências e consultas públicas ${ }^{209}$, de conferências sobre assuntos de interesse urbano, em todos os níveis, da iniciativa popular de projetos de lei e de planos, programas e projetos de desenvolvimento urbano. ${ }^{210}$

206. Plano Diretor, para Carlos Alberto Dabus Maluf e Adriana Caldas do Rego Freitas Dabus Maulf, "é a lei que deverá fixar e sistematizar o desenvolvimento do território municipal, podendo assim estabelecer coeficientes de aproveitamento para certas áreas da cidade, além de sistematizar o desenvolvimento físico, econômico e social do município, visando preservar o bem estar da comunidade local" (cit. p. 37)

207 Conferir em Drobenko, a equivalência do Plano Local de Urbanismo - PLU, documento de referência da regulamentação urbana local (cit. pp. 107-127), bem como as 'Cartes Communales' das pequenas cidades (idem p. 127-129).

208 Ver Régis Fernandes de Oliveira, Instrumentos brasileiros de defesa e participação dos administrados, Revista dos Tribunais, vol. 677, mar./1992, p. 82-94.

209 Cuja não realização importa em improbidade administrativa.

210 Daniela Campos Libório Di Sárnio detalha com propriedade as fases do procedimento de realização das audiências públicas (fases preparatória, presencial e posterior), bem como princípios a serem observados (devido processo legal, informalismo, oralidade e publicidade). Audiência pública na gestão democrática da cidade, in Adilson Abreu Dallari e Daniela Campos Libório Di Sarno (Coord.), Direito urbanístico e ambiental, Belo Horizonte, Fórum, 2007, p. 49-71.

Formatado: Fonte: $10 \mathrm{pt}$

Formatado: Fonte: $10 \mathrm{pt}$

Formatado: Fonte: $10 \mathrm{pt}$

Formatado: Fonte: $10 \mathrm{pt}$ 
A concepção do plano diretor ${ }^{211}$ evoluiu, destinado inicialmente ao esboço do desenho da cidade, traçado das ruas e destinação de espaço para edifícios públicos, bem como à distribuição de edificações no território, atendendo-se a funções econômicas e arquitetônicas. Posteriormente, passou a ser instrumento de desenvolvimento do processo do planejamento municipal destinado a alcançar objetivos integrados nos campos físico, econômico, social e administrativo. Com a Constituição da República de 1988, art. 182, o plano diretor assume a função de instrumento básico da política urbana do Município que tem por objetivo ordenar o pleno desenvolvimento das funções sociais da cidade e garantir o bem-estar da comunidade.

A obrigatoriedade prevista inicialmente pela Lei Maior para municípios com mais de vinte mil habitantes, foi ampliada pelo art. 41 da Lei para aqueles integrantes de regiões metropolitanas e aglomerações urbanas ${ }^{212}$, onde o Município pretenda utilizar os instrumentos do art., 182, § $4^{\circ}$ da Constituição Federal, para integrantes de áreas de especial interesse turístico (ou seja, a quase totalidade dos municípios litorâneos), e inseridas na área de influência de empreendimentos ou atividades com impacto ambiental de âmbito regional ou nacional.

\section{FLORIANO DE AZEVEDO MARQUES NETO e JOÃO EDUARDO LOPES QUEIROZ,} em aprofundado trabalho sobre planejamento, observam o caráter vinculante de alguns aspectos do plano diretor, o que foge de certa forma à regra do art. 174 da Constituição Federal que alude ao caráter indicativo para a iniciativa privada, salientando que o plano

211. Cf. supra 1.2.2.b.

212 Vale lembrar que mesmo a competência atribuída pelo art. $25, \S 3^{\circ}$ da Constituição Federal para a instituição de regiões metropolitanas, aglomerações urbanas e microrregiões só se efetivará na medida Formatado: Fonte: (Padrão) Arial, 10 em que os Municípios afetados queiram agir em conjunto. 
diretor resulta num processo de planificação da Administração Municipal e Distrital que orientará toda sua ação, do plano físico-territorial até a orçamentação dos gastos e despesas públicas. Conclui que o plano diretor tem por função estabelecer critérios para se verificar se a propriedade atende à sua função social; por objetivo estabelecer metas e diretrizes da política urbana e normas que condicionam o uso, gozo e disposição da propriedade; e o dever de estabelecer os critérios para utilização dos instrumentos criados pelo Estatuto da Cidade, tais como outorga onerosa do direito de construir, operações urbanas consorciadas, parcelamento, utilização compulsória com aplicação do IPTU progressivo e outros institutos. $^{213}$

Em relação ao plano diretor em municípios localizados na zona costeira, objeto desta tese, SHEILA CAVALCANTE PITOMBEIRA pondera que "no âmbito da competência municipal exclusiva, há de ser observado que o Plano Diretor, instrumento legal orientador da política de desenvolvimento urbano do Município, não poderá deixar de contemplar regras de uso e de ocupação que observem a integridade e higidez do meio ambiente costeiro da localidade, segundo o respectivo ZEE. E, na hipótese de o plano diretor ainda não ter sido elaborado, embora obrigatório de acordo com a previsão legal (art. 41 e segs. do Estatuto da Cidade), não poderá dispensar o ZEE se integrante da zona costeira. Em casos tais, o gerenciamento costeiro, por sua vez, não poderá desconsiderar e/ou deixar de perseguir a harmonia entre as duas instâncias (o ZEE e o Plano Diretor)". 214

213 Planejamento, in José Eduardo Martins Cardozo, João Eduardo Lopes Queiroz e Márcia Walquíria Batista dos Santos, Curso de direito administrativo econômico, p. 40-127.

214 Gerenciamento costeiro, in Marcelo Buzaglio Dantas, Elida Seguin e Flávio Abmet, O Direito ambiental na atualidade - Estudos em homenagem a Guilherme José Purvin de Figueiredo, p. 437452. 
Estudo de caso realizado na Costa Potiguar $^{215}$ aponta a fragilidade dos Municípios na implementação da gestão costeira sustentável potiguar e a necessidade dos Estados fornecerem o apoio necessário, o que só reforça a necessidade de adesão ao Projeto Orla: “O Plano de Desenvolvimento Integrado de Turismo Sustentável para o Polo Costa das Dunas (PDITS) registra os investimentos na primeira etapa do PRODETUR para a elaboração de Planos Diretores, pois dos trinta e cinco municípios da zona costeira do Estado, apenas seis situados no Litoral Oriental possuem Planos Diretores. Apesar da iniciativa do poder público estadual no sentido de dotar as administrações municipais de instrumentos de normatização do uso e ocupação do solo como parte das ações da PRODETUR-RN e da SUGERCO, essas normas não tem sido usadas na sua plenitude na prática das frágeis administrações municipais. Exemplificando, o município de Parnamirim que, apesar de ser um dos mais adiantados na implementação do Plano, tem se limitado a utilizar apenas as prescrições urbanísticas, passando ao largo com relação à instauração de instrumentos importantes e complementares para a política urbana".

Outrossim, o plano diretor deve englobar o Município como um todo e não apenas seu perímetro urbano e urbanizável ${ }^{216}$, assegurada a publicidade e a participação popular, bem como a revisão periódica.

Cria-se também uma reserva material ao plano diretor, impedindo que possam ser reguladas por outros instrumentos: delimitação das zonas urbanas, de expansão urbana, de urbanização específica e de interesse social; estabelecimento de índices urbanísticos relativos a áreas

215 Ana Maria Teixeira Marcelino, A gestão Costeira Potiguar, Gestão Costeira Integrada, no 5, 2006, p. $10-17$.

216 Contra: Castilho, cit., p. 146 "Ao longo deste trabalho já ficou consignado que o Plano Diretor refere-se à conformação do solo urbano e urbanizável (área urbana e de expansão); isto é, exclui-se de sua abrangência o solo com destino rural". Cf. supra 2.2 
mínimas e máximas de lotes e coeficientes básicos ${ }^{217}$, máximos e mínimos de aproveitamento; delimitação de áreas cuja vegetação natural deva ser preservada ou suprimida; traçado do sistema viário principal da cidade, existente e projetado; bases para a utilização do direito de preempção, das operações consorciadas e da transferência do direito de construir. ${ }^{218}$

Destarte, firma-se o entendimento de que o plano diretor (especialmente se conjugado com o Projeto Orla) oferece ao Município costeiro, nos limites da competência atribuída pela Constituição Federal, instrumentos suficientes para a adequada e eficaz defesa do interesse local. $^{219}$

217 Em novembro de 2011 a Câmara Municipal de Caraguatatuba aprovou Plano Diretor autorizando a construção de prédios de até dezoito andares, ante o limite anterior de nove, na área denominada Fazenda Serramar, para empreendimentos residenciais e comerciais onde já funciona o maior Shopping Center do Litoral Norte, afastado da faixa de marinha, da orla e da Serra do Mar, compatibilizando a necessidade de infraestrutura para a cidade, sede das operações de gás do pré-sal, com a preservação ambiental.

218 Victor Carvalho Pinto, Direito urbanístico, p. 190.

$219 \mathrm{Em}$ relação aos demais instrumentos do art. $4^{\circ}$ da Lei no 10.257, de 10.07.2001, conferir: Adilson de Abreu Dallari e Sérgio Ferraz (Coord.), Estatuto da cidade, São Paulo, Malheiros; Carlos Alberto Dabus Maluf e Adriana Caldas do Rego Freitas Dabus Maluf, Comentários ao estatuto da cidade, São Paulo, Atlas; Odete Medauar e Fernando Dias Menezes de Almeida (Coord.), Estatuto da cidade: Lei $n$. 10.257/2001, São Paulo, Revista dos Tribunais; Régis Fernandes de Oliveira, Comentários ao estatuto da cidade, São Paulo, Revista dos Tribunais, 2005; Victor Carvalho Pinto, Direito urbanístico, 2 ed., São Paulo, Revista dos Tribunais, 2010; José Afonso da Silva, Direito urbanístico, São Paulo, Malheiros. 


\section{O MUNICÍPIO NA PROMOÇÃO DO INTERESSE LOCAL}

O estabelecimento da competência precípua no Município na regulamentação do uso e ocupação do solo urbano e das atividades desenvolvidas na zona costeira urbana, inclusive nos denominados terrenos de marinha e acrescidos, acirra o debate em torno de questões tradicionais, como o exercício do poder de polícia municipal em relação ao exercício de determinadas atividades, e a manutenção de acesso livre e desembaraçado à praia, bem de uso comum do povo.

Em outra via, suscita reflexão sobre o papel do Município no enfrentamento de demandas atuais, tais como o desenvolvimento da promissora indústria do turismo, a atividade de exploração de petróleo e gás na plataforma continental, e o necessário redimensionamento do sistema portuário.

\subsection{Exercício do poder de polícia pelo Município}

A norma francesa de 22.12.1789/08.01.1790 contém a primeira previsão do poder de polícia, na afirmação de que competia aos administradores dos Departamentos a manutenção da salubridade, da segurança e da tranquilidade públicas. Um ano e três meses após, no Decreto 
d'Allarde, de 17.03.1791, art. $7^{\circ}$, a Assembleia determinava que a partir de primeiro de abril daquele ano seria livre a qualquer pessoa a realização de qualquer negócio ou o exercício de qualquer profissão, arte ou ofício que lhe aprouvesse, desde que se munisse previamente de uma patente (imposto direto), pagasse as taxas exigíveis e se sujeitasse aos regulamentos de polícia aplicáveis. ${ }^{220}$

A expressão police power ingressa, pela primeira vez na terminologia legal, no julgamento pela Corte Suprema do caso Brown versus Maryland e reaparece em outros julgados, a partir de 1827 , como limite ao direito de propriedade para subordiná-lo a interesses respeitáveis da comunidade. Tendo como origem os poderes residuais dos Estados-membros, o police power passou a exprimir a competência legislativa estadual para regular direitos privados em benefício do interesse coletivo. ${ }^{221}$

No direito brasileiro, o instituto encontra-se plasmado na regra do art. 78 do Código Tributário Nacional.

220 Eros Grau, Poder de polícia: função administrativa e princípio da legalidade. O chamado direito alternativo, Revista Trimestral de Direito Público, oㅜ 1, 1993, p. 94.

221 Caio Tácito, Princípio da legalidade e poder de polícia, Revista de Direito, v. 5, oㅜ 10, jul./dez. 2001, p. 18. 
É a faculdade de que dispõe a Administração Pública para condicionar e restringir o uso e gozo de bens, atividades e direitos individuais, em benefício da saúde, sossego e segurança da coletividade ou do próprio Estado, com fundamentos na ordem e no interesse público. ${ }^{222}$

ODETE MEDAUAR ${ }^{223}$ conceitua poder de polícia como “a atividade da Administração que impõe limites ao exercício de direitos e liberdade. É uma das atividades em que mais se expressa sua face autoridade, sua face imperativa. Onde existe um ordenamento, este não pode deixar de adotar medidas para disciplinar o exercício de direitos fundamentais de indivíduos e grupos. Trata-se de tema que diretamente se insere na encruzilhada liberdadeautoridade, Estado-indivíduo, que permeia o direito administrativo e o direito público, revelando-se muito sensível à índole do Estado e às características históricas, políticas e econômicas dos países. Outras denominações mais suaves vêm sendo utilizadas para designar essa atividade da Administração como: poder ordenador, atividade interventora”.

Entre as mencionadas denominações, CARLOS ARI SUNDFELD alude ao conceito de Administração ordenadora ${ }^{224}$ como a "parcela da função administrativa, desenvolvida com o uso do poder de autoridade, para disciplinar, nos termos e para os fins da lei, os comportamentos dos particulares no campo de atividades que lhes é próprio. Não se confunde com a regulamentação legislativa dos direitos e deveres, visto envolver o exercício de função

222 Nesse sentido a lição de Eros Grau ao asseverar que "a coibição da perturbação da ordem, no campo da salubridade, da segurança e da tranquilidade públicas, permanecia de toda sorte, consubstanciando a finalidade do poder de polícia" (Poder de polícia: função administrativa e princípio da legalidade. $O$ chamado direito alternativo. Revista Trimestral de Direito Público, no 1/1993, p. 94).

223 Direito administrativo moderno, p. 366

224 Direito administrativo ordenador, São Paulo, Malheiros, 2003, p. 20. 
administrativa. Pela mesma circunstância, difere da decisão de conflitos pelo Poder Judiciário. Não se assemelha à disciplina dos vínculos entre a Administração e seus servidores, delegatários ou contratados, por atinar à ordenação do campo privado, não do setor público; por isso mesmo, desenvolve-se dentro de relação genérica - não de relação especial - da Administração com os particulares. Por fim, distingue-se de outras interferências no campo privado, com a exploração econômica estatal e o fomento, porquanto, de uma parte, objetiva regular a aquisição, exercício e perda de direitos pelos particulares (ao contrário da exploração econômica estatal, que visa substituir a privada) e, de outra, implica na utilização do poder de autoridade, inexistente na atividade de fomento. A exata compreensão da administração ordenadora demanda, assim, que fiquem evidenciados seus caracteres fundamentais: a) trata-se de exercício de função administrativa; b) voltado à organização da vida privada; c) dentro de relação genérica; d) com a utilização do poder de autoridade".

Dessa forma, na defesa da supremacia dos interesses sociais ${ }^{225}$, pode a Administração impor limites à liberdade e propriedade individual, um non facere, na forma e nos termos da lei, mediante ação fiscalizadora, preventiva ou repressiva, mais ou menos intrusiva, a fim de assegurar o bem estar da sociedade. ${ }^{226}$

225 De acordo com José Nilo de Castro, "exercita-se o poder de polícia administrativo municipal nas matérias e assuntos de interesse local, tais como proteção à saúde (aí incluídas a vigilância e a fiscalização sanitária), proteção ao meio ambiente, ao sossego, à higiene, à funcionalidade. Disciplinam-se as edificações e as posturas municipais, em toda amplitude local, como a regulamentação de horário de funcionamento do comércio local, de indústria, de prestação de serviços (salvo atividade bancarias e financeiras); tráfego, trânsito e transporte no perímetro urbano e nas vias públicas municipais; proteção ecológica da fauna e flora; localização nas áreas urbanas e nas proximidades de culturas e mananciais, de substâncias potencialmente perigosas; estética urbana e guarda municipal - art. 144, § 8, CF” (Direito municipal positivo, Belo Horizonte, Del Rey, 2006, p. 332).

226 Alf Ross alude à quimera do bem-estar social, nestes termos: "Nos tempos modernos, tornou-se hábito falar de bem-estar social, das necessidades da comunidade, etc., em lugar da soma total do prazer dos indivíduos. A introdução do conceito de sociedade como um sujeito único, cujo bem estar deve ser promovido na maior medida possível, permitiu contornar, mas não superar, os dois direitos fundamentais do utilitarismo: a incomensurabilidade das necessidades e a desarmonia dos interesses. 
Nesta quadra, o diálogo enquanto instrumento consensual emerge como procedimento balizador, presente nos mecanismos de acordos regulatórios ${ }^{227}$, audiência e consulta públicas, com permanente revisão das decisões e sopesamento de críticas e sugestões, fazendo com que a regulação tende a adquirir muito mais feição contratual do que impositiva de autoridade.

CARLOS ARI SUNDFELD ${ }^{228}$ justifica a substituição da limitada ideia de polícia, pois “hoje em dia se exige do titular do direito subjetivo que, usando da posição que este lhe assegura, colabore com a construção de uma nova realidade. Em uma frase, à administração ordenadora não basta que este indivíduo não perturbe, é mister que este indivíduo ajude, na medida das possibilidades propiciadas pelo exercício de seu direito. Quem é proprietário de um bem, quem controla uma empresa deve cumprir sua função social. Em consequência disso, a administração ordenadora e os condicionamentos que ela impõe (limites, encargos e sujeições), não têm apenas sentido negativo, mas também conteúdo positivo”.

FLORIANO DE AZEVEDO MARQUES NETO ${ }^{229}$ lembra: “embora sendo uma área da Administração presente desde tempos imemoriais - e até talvez por isso, a concepção de poder

A ideia de que a comunidade é uma entidade independente, com necessidades e interesses próprios, deve ser rejeitada como ilusória. Todas as necessidades humanas são experimentadas pelo indivíduo e o bem estar da comunidade é o mesmo que o de seus membros, de sorte que retornamos às mesmas dificuldades anteriores" (Direito e justiça, São Paulo, Edipro, 2003, p. 341-342).

227 Sobre autorizações administrativas, poder de polícia e regulação, conferir: Alexandre Santos de Aragão, Autorizações administrativas, Revista Tributária e de Finanças Públicas, vol. 62, mai./jun. 2005, pp. 192/212; Atividades privadas regulamentadas: poder de polícia e regulação, Revista Forense, vol. 383, jan./fev. 2006, p. 03-24.

228 Cit, p. 57.

229 A possibilidade de restrição de acesso a bens públicos de uso comum por questões ambientais e urbanísticas, Boletim de Direito Administrativo, 6, jun. 2007, p. 672-673. 
de polícia suscita inúmeras imprecisões, dúvidas e controvérsias. A tal ponto que doutrinadores de escol propugnam pela eliminação da própria ideia de poder de polícia, enquanto outros, com brilho também destacado, defendem a reformulação da vetusta noção, que deveria dar lugar a fórmulas da 'Administração Ordenadora"”.

Assim, a consensualidade pode alcançar até mesmo $o$ poder de polícia enquanto atividade administrativa intrinsecamente estatal de ordenação de conduta que condiciona, incentiva, limita ou sacrifica direitos com vistas a uma organização comportamental ou de mercado, para que se alcance padrão de conduta "entendido" pela Constituição ou pela lei como ótimo.

A atuação da Administração Pública pela via intrusiva do poder de polícia difere da regulação porque na regulação não há sujeição geral, mas participação voluntária em uma atividade. Portanto, embora a regulação não deixe de ser espécie de poder de polícia, na regulação o exercício vertical da autoridade é exceção, e no poder de polícia a regra. ${ }^{230}$

230 De acordo com Virgílio Afonso da Silva, "A distinção entre regulação e restrição dos direitos fundamentais, que está na base de algumas estratégias de limitação do suporte fático dos direitos fundamentais, não é despida de problemas conceituais, e tem enormes consequências práticas. $\mathrm{Na}$ exposição do modelo proposto por Rawls ficou claro que essa distinção tem um objetivo simples e, ao mesmo tempo, fundamental: distinguir aquilo que é permitido daquilo que não é. Assim, para Rawls toda forma de intervenção no 'conteúdo' das liberdades fundamentais é uma forma de restrição - e, portanto, deve a ser rejeitada. Já intervenções na 'forma de exercício' das liberdades fundamentais seriam aceitas, pois, nesses casos, estaríamos diante de 'meras regulamentações"' (Direitos fundamentais, conteúdo essencial, restrição e eficácia, p. 100).

A respeito do assunto, Robert Alexy preceitua: "Por 'direitos de proteção' devem ser aqui entendidos os direitos do titular de direitos fundamentais em face do Estado a que este o projeta contra intervenções de terceiros. Os Direitos à proteção podem ter os mais diferentes objetos (...) O que há de comum em meio a essa diversidade é o fato de que os diretos à proteção são direitos subjetivos constitucionais a ações positivas fáticas ou normativas em face do Estado, que tem como objeto demarcar as esferas dos sujeitos de direito de mesma hierarquia, bem como a exigibilidade e a realização dessa demarcação. A delimitação das esferas dos sujeitos de direito de mesma hierarquia, bem como a garantia da exigibilidade e da realização dessa demarcação, é uma das tarefas clássicas da ordem jurídica. A conhecida formulação de Kant tem-na como objeto: 'o direito é, portanto, o conjunto das condições sob as quais o arbítrio de um pode ser conciliado com o arbítrio do outro, de acordo com a lei geral de liberdade. Direitos à proteção são, nesse sentido, direitos constitucionais a que o Estado configura e aplica a ordem jurídica de uma determinada maioria, no que diz respeito à relação dos sujeitos de direito de mesma hierarquia entre si" ( Teoria dos direitos fundamentais, p. 450-451). 
Ocorre que o núcleo essencial do poder de polícia (saúde, sossego e segurança, como já visto) vem se alargando, objetivando padrões de comportamento em outras áreas (como no domínio econômico, ambiental, profissões), ensejando o desenvolvimento de novos instrumentos, não apenas negativos, mas também positivos, como as sanções premiais.

É o entendimento de HANS KELSEN ${ }^{231}$ a respeito das mencionadas sanções: “A ordem social pode prescrever uma determinada conduta humana sem ligar à observância ou não observância deste imperativo quaisquer consequências. Também pode, porém, estatuir uma determinada conduta humana e, simultaneamente, ligar a esta conduta a concessão de uma vantagem, de um prêmio, ou ligar à conduta oposta uma desvantagem, uma pena (no sentido mais amplo da palavra). O princípio, que conduz a reagir a uma determinada conduta com um prêmio ou uma pena é o princípio retributivo. O prêmio e o castigo podem compreender-se no conceito de sanção. No entanto, usualmente, designa-se por sanção somente a pena, isto é, um mal - a privação de certos bens como a vida, a saúde, a liberdade, a honra, valores econômicos - a aplicar como consequência de uma determinada conduta, mas já não o prêmio ou a recompensa".

MIGUEL REALE ${ }^{232}$, já lembrava que “atualmente, excogitam-se técnicas mais aperfeiçoadas para obter-se o cumprimento das normas jurídicas, através não de sanções intimidativas, mas sim através de processos que possam influir no sentido da adesão espontânea dos obrigados, como os que propiciam incentivos e vantagens. Assim, ao lado das sanções penais, temos as

231 Teoria pura do Direito, 6 ed. Coimbra, Armênio Amado, 1984, p. 49

232 Lições preliminares de Direito, 27 ed., São Paulo, Saraiva, 2002, p. 75-76. 
sanções premiais, que oferecem um benefício ao destinatário, como, por exemplo, um desconto ao contribuinte que paga um tributo antes da data do vencimento".

Na zona costeira, a proteção conferida ao interesse local é levada a cabo de forma preponderante pelo Município $^{233}$, tendendo sua competência a se ampliar, e se dá, entre outras modalidades, pela via intrusiva do exercício do poder de polícia, não apenas no que diz respeito à atividade de ambulantes, prática de esportes na areia da praia, colocação de barracas, retirada de areia da praia para desobstruir canais ou calçadas, disciplinar a circulação, o trânsito, cuidar da higiene e da limpeza nessas áreas de uso comum do povo ${ }^{234}$, simultaneamente bens da União e logradouros municipais. Compete-lhe, também, elaborar o planejamento mais amplo possível, e executar esse planejamento, abrangendo toda a sua área territorial, no que diz respeito às funções da cidade.

As construções ${ }^{235}$, o exercício e fiscalização das atividades ${ }^{236}$ realizadas em áreas urbanas ou urbanizáveis são sujeitas à disciplina e tributação municipais, assim como a garantia de acesso

233 Conferir sobre poder de polícia do Município: loberto Tatsch Banunas, Poder de polícia ambiental e o município, Porto Alegre, Sulinas, 2003; Heraldo Garcia Vitta, Poder de polícia, São Paulo, Malheiros, 2010. Cf. também supra 2.2.

$234 \mathrm{Em}$ estudo sobre políticas públicas como ferramenta do gerenciamento costeiro na Praia da Cocanha (Caraguatatiba/SP), por Jussara Shirazawa de Freitas e Yara Schaeffer Novelli (Instituto Oceanográfico - USP) - V Simpósio Brasileiro de Oceanografia, as autoras mencionam a distância entre os tomadores de decisões e os atores e usuários da região, salientando a inobservância da região delimitada para os quiosques, erosão causada pela mudança do curso do Rio Cocanha, acúmulo de lixo no loca, dentre outras, na praia que vive do turismo e da marricultura: "Ressalta-se, mas uma vez, que é no plano local que são constituídas as identidades e estruturadas as redes para uma eficaz gestão. Portanto, o nível de participação local deve ser reforçado na busca do desenvolvimento sustentável e na construção de políticas públicas, porque é no âmbito local que os grupos podem interferir, reivindicar e negociar com maior legitimidade o Gerenciamento Costeiro Integrado".

235 A seguir alguns julgados colacionados sobre construções na zona costeira:

Construções irregulares em terrenos de marinha - Omissão na fiscalização - Responsabilidade objetiva do Estado - Dano moral ressarcível. Competência dos municípios para a promoção do adequado ordenamento territorial, mediante o planejamento do uso, do parcelamento e da ocupação 
do solo urbano, e da Capitania dos Portos quanto à fiscalização de execução de obra pública ou particular em terrenos de marinha e seus acrescidos (TRF 5a , AC 2000.05.00.049384-5/PB, Rel. Des. Fed. Edílson Nobre, D.J.U., de 02.12.05, p. 1.016. STF RE 510242/PE, não conhecido com trânsito em julgado em 04.10.2007).

Construção em área de preservação permanente - Promontório - Terreno de Marinha - Obra embargada pelo IBAMA - Falta de licença do Município - Autorização da FATMA - Irrelevância Clandestinidade - Demolição pelo exercício do poder de polícia (TJSC, ACMS 021515-5, Rel. Des. Newton Janke, j. 27.11.2003. STF AI 572169 - 2000.021515.5, trânsito em julgado em 12.05.2006).

Edificação erguida em bem imóvel pertencente à União Federal - Ausência de autorização do Poder Municipal - Violação das normas contidas no Código de Obras do Município - Ausência de manifestação de interesse da União - Causa de pedir da ação demolitória ligada a preservação ambiental - Competência de proteção do meio ambiente comum a todos os entes da Federação (art. 23, VI, da CF/88) (TJRJ, AC 001.07577, 1a Câmara Cível, Re. Des. Celio Geraldo M. Ribeiro, j. 06.06.2006. STF 2006.001.07577 - 0000067.36.2001.8.19.0030, trânsito em 03.11.2010).

236 Segue abaixo jurisprudência relativa ao exercício do poder de polícia sobre as atividades desenvolvidas na zona costeira:

Comércio junto ao calçadão na orla da praia do Município de Pelotas - Unilateralidade e precariedade do ato administrativo consistente na autorização de uso - Demanda objetivando a desconstituição de autos de infração - Autuação baseada na existência de construção em solo público, com afronta à legislação ambiental - Proposta de edificação oferecida pela própria Municipalidade - Ação procedente - Recurso não provido. (TJRS, AC 7000678543, 22 $2^{a}$ Câmara Civil, Rel. Des. Otávio Stem, j. 09.09.2003).

Exploração de pedalinhos - Restrições por Lei Municipal. As disposições da lei devem ser interpretadas à luz dos princípios que a inspiram. Prescrevendo a lei restrições à exploração dos denominados pedalinhos, não viola direito líquido e certo a decisão administrativa que delimita os pontos de locação de equipamentos para atender aos objetivos da norma legal: "proteger os banhistas". (TJSC, Al 001416-8, Rel. Des. Newton Trisotto, j. 22.04.2002).

Edificação de quiosque na orla marítima - Delegacia do patrimônio da União - Notificação de demolição - Inexistência do devido processo administrativo. O desfazimento de situação fática e jurídica consolidada ao longo do tempo, ainda que no legítimo poder de polícia, deve ser mediante prévio processo administrativo garantido a ampla defesa e o contraditório, salvo se houver efetiva necessidade do interesse público. (TRF 2a Ricardo Perlingeiro, j. 28.06.2001 - trânsito em julgado em 08.07.2005).

Instalação de quiosques na orla marítima do Rio de Janeiro. Ação popular proposta objetivando obter declaração de nulidade do Termo de Concessão de Uso no 417/99, firmado entre o Município do Rio de Janeiro e a Orla Rio Associados Ltda. A construção de quiosques na orla marítima do Rio de Janeiro não implica no referido impacto ambiental razão por que foi dispensada a elaboração do EIA/RIMA, cabendo a FEEMA o seu licenciamento. Os terrenos de Marinha ocupados pelos quiosques foram devidamente regularizados perante o SPU, tendo o Município do Rio de Janeiro autonomia para realizar as intervenções necessárias ao uso ordenado das praias. Os quiosques situam-se em áreas urbanizadas, dotadas de estrutura sanitária adequada, e as suas dimensões não comprometem o conjunto paisagístico da orla marítima (TRF 2 ${ }^{a}$, AC 51.01.013719-0/RJ, 372773, 5aㅜ Turma, Rel. Des. Fed. Paulo Espírito Santo, j. 09.08.2006).

Remoção das choupanas e acrescidos de bar das areias da praia. Não há qualquer ilegalidade na notificação feita ao impetrante no sentido de desocupar a área ilegitimamente ocupada, independentemente do tempo em que o mesmo se manteve no local sem ser importunado - Decreto-lei 9.760/46. Decreto-Lei $n^{\circ}$ 2398/87. Lei 7661/98. art. 11 da Lei 9.636/98. (TRF 2 - MAS 56179/ES 200250010011953, T8, Rel. Des. Fed. Poul Erik Dyrlund, j. 08.08.2006 - trânsito em julgado em 10.10.2006). 
público às praias, cabendo a reserva dominial da União aos aspectos ligados à defesa nacional, bem como à disciplina geral da matéria.

\subsection{Garantia de acesso à praia}

A proteção conferida ao uso comum e ao acesso à praia constitui outro relevante aspecto do exercício da competência municipal na zona costeira.

Habitada desde o início da ocupação do território brasileiro e valorizada em razão da indústria do turismo, representa traço marcante da identidade nacional brasileira, com paralelo nos exemplos australianos, norte-americanos (estados da Flórida e Califórnia) e na Europa Mediterrânea. ${ }^{237}$

$\mathrm{O}$ art. 10 da Lei $\mathrm{n}^{\mathrm{o}} 7.661$, de $16.05 .1988^{238}$, contém a definição legal de praia e assegura o livre e franco acesso enquanto bens de uso comum do povo.

237 Sobre a evolução histórica da disciplina jurídica da praia no direito brasileiro, conferir Gilberto D'Ávila Rufino, A condição jurídica dos aterros das praias do mar, Revista de Direito Público Cadernos de Direito Municipal, v. 97, São Paulo, Revista dos Tribunais, jan.-mar. 1991, p. $243-252$.

238 Art. 10. As praias são bens públicos de uso comum do povo, sendo assegurado, sempre, livre e franco acesso a elas e ao mar, em qualquer direção e sentido, ressalvados os trechos considerados de

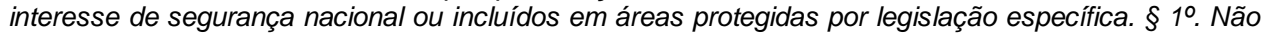
será permitida a urbanização ou qualquer forma de utilização do solo na Zona Costeira que impeça ou dificulte $o$ acesso assegurado no caput deste artigo. $\S 2 \%$. A regulamentação desta lei determinará as características e as modalidades de acesso que garantam o uso público das praias e do mar. $\S 3^{\circ}$. 
Na doutrina, de acordo com CAIO TÁCITO ${ }^{239}$ : “praia é o domínio público sobre o mar territorial e compreende tanto a massa líquida como a porção terrestre sobre a qual se desenvolve o movimento das marés. Conteúdo e continente se integram no domínio marítimo que a União exerce, como um dos bens públicos de uso comum do povo. A porção submersa do território litorâneo caracteriza o leito do mar (lido) que se prolonga, sem solução de continuidade, na praia até o limite da máxima maré".

Como visto no curso deste trabalho, as praias constituem bens de uso comum do povo ${ }^{240}$, portanto inalienáveis, enquanto os terrenos de marinha são bens dominicais, aforáveis e não completamente alienáveis.

O uso e o gozo público e indistinto, universal e geral, são atributos inerentes a condição de bem público de uso comum do povo, sendo dever do poder público garantir esse uso uti universi.

O deslumbramento de algumas autoridades municipais diante do desenvolvimento econômico-turístico, prepondera sobre uma visão em longo prazo e favorece a progressiva privatização do litoral, submetendo-se à pressão dos interesses dos empreendedores, quadro

Entende-se por praia a área coberta e descoberta periodicamente pelas águas, acrescida da faixa subsequente de material detrítico, tal como areias, cascalhos, seixos e pedregulhos, até o limite onde se inicie a vegetação natural, ou, em sua ausência, onde comece outro ecossistema.

239 Terrenos de marinha - Praia - Defesa da fauna, Revista de Direito Administrativo vol. 162, out.dez. 1985, p. 312.

240 Cf. supra 1.1, 1.3.1 e 1.3.2. 
agravado pela inoperância do poder público quanto à ocupação privada de áreas públicas, pela omissão quanto à criação de infraestrutura apropriada ao litoral e por uma legislação obsoleta.

Também os terrenos acrescidos, oriundos de fenômenos naturais, conservam a mesma natureza jurídica do fundo do mar em relação ao qual são acessórios, resultando evidente a dominialidade pública, condição essa que conservam enquanto não intervém um ato formal de desclassificação. No caso de aterro artificial, os terrenos conquistados só perdem a dominialidade pública por ato da Administração Pública.

No sentido interior do território, uma sequência de espécie de bens se oferece à incidência de diversos regimes jurídicos: a partir do mar territorial colocam-se, sucessivamente, as praias, as terras de marinha e os terrenos alodiais. Nas primeiras é pleno e exclusivo o domínio público, vedado constituir-se domínio privado; nos últimos, como regra, prevalece a livre propriedade particular; nas intermediárias, convivem o domínio direto do senhorial público e o domínio útil do titular do aforamento. ${ }^{241}$

241 A respeito do assunto, Caio Tácito observa: "Nas praias o uso público é incontrastável, ele se opõe, nos terrenos alodiais e nas terras de marinha o direito de propriedade constituído na forma da lei (...) Nenhum texto de lei assegura passagem livre, atravessando os terrenos alodiais e as áreas aforadas dos terrenos de marinha, no sentido do acesso às praias, sobrepondo-se à sua disponibilidade pelos respectivos proprietários. Nos terrenos alodiais, a lei civil garante ao proprietário ou ao possuidor a integralidade de seu direito. Nos aforamentos dos terrenos de marinha, de igual modo, o domínio útil, adquirido a título legítimo, defende o enfiteuta da violação do uso, que lhe é privativo (...) Não se presume a servidão, inclusive as servidões administrativas, que a administração venha a constituir, no exercício regular de sua competência legal. A restrição ao domínio com efeito de servidão administrativa coloca em causa o princípio da legalidade (...) Não é dado ao usuário (qualquer do povo) penetrar livremente na propriedade privada, escolhendo a via de acesso que the pareça conveniente. Nem ao proprietário se impõe o dever de suportar indeterminadamente a passagem que Ihe perturba a eficácia do domínio. A União, titular do domínio público dos terrenos de marinha, 
Conclui-se no sentido de que o acesso à praia é sempre livre pelo mar ou pela própria continuidade do litoral. $\mathrm{O}$ acesso por terra somente é facultado a qualquer do povo pela via pública contígua à praia ou mediante servidão administrativa regularmente constituída na forma da lei, incidente sobre a propriedade alodial ou terreno de marinha objeto de aforamento, ou seja, quando limitado, por ato específico e válido, o domínio privado. Portanto, o franco e desembaraçado acesso de todos à praia, enquanto bem de uso comum do povo, implica em limitação ao direito de propriedade privada ${ }^{242}$, na forma prevista no art. 10 da Lei $n^{\circ} 7.661$, de 16.05.1988, art. $4^{\circ}, \S 1^{\circ}$ da $L F n^{\circ} 9.636$, de 15.05.1998. ${ }^{243}$

De acordo com o art. 21 do Decreto $\mathrm{n}^{\mathrm{o}} 5.300$, de 07.12.2004 $4^{244}$, o Município, em conjunto com o órgão ambiental, assegurará no âmbito do planejamento urbano, o acesso às praias e ao mar, ressalvadas as áreas de segurança nacional ou áreas protegidas por legislação específica.

poderá, no ato do aforamento, clausular o domínio útil do enfiteuta, predeterminando o ônus de suportar, qualificadamente, o local e a forma de acesso à praia. Se não o houver feito ou quando a passagem atingir a alodialidade, deverá constituir, por ato específico, a correspondente servidão administrativa, por via amigável ou imperativa, a ser inscrita no Registro de Imóveis" (Revista de Direito Administrativo, no 162, out.-dez. 1985, p. 313).

242 A propósito das limitações ao direito de propriedade, conferir trabalho clássico de Carlos Alberto Dabus Maluf, Limitações ao direito de propriedade. 3 ed. São Paulo: Revista dos Tribunais, 2011.

243 Lei $n^{\circ}$ 9.636, art. $4^{\circ}, \S^{\circ} \stackrel{\circ}{ }$. Na elaboração e execução dos projetos de que trata este artigo, serão sempre respeitados a preservação e o livre acesso às praias marítimas, fluviais e lacustres e a outras áreas de uso comum do povo.

244 Decreto ํㅜ 5.300, de 07.12.2004, art. 21. As praias são bens públicos de uso comum do povo, sendo assegurado, sempre, livre e franco acesso a elas e ao mar, em qualquer direção e sentido, ressalvados os trechos considerados de interesse da segurança nacional ou incluídos em áreas protegidas por legislação específica. § $1^{\circ} \mathrm{O}$ Poder Público Municipal, em conjunto com o órgão ambiental, assegurará no âmbito do planejamento urbano, o acesso às praias e ao mar, ressalvadas as áreas de segurança nacional ou áreas protegidas por legislação específica, considerando os seguintes critérios: I - nas áreas a serem loteadas, o projeto do loteamento identificará os locais de acesso à praia, conforme competências dispostas nos instrumentos normativos estaduais ou municipais; II - nas áreas já ocupadas por loteamentos à beira mar, sem acesso à praia, o Poder Público Municipal, em conjunto com o órgão ambiental, definirá as áreas de servidão de passagem, responsabilizando-se por 
A Secretaria do Patrimônio da União, o órgão ambiental e o Município decidirão os casos omissos do aludido Decreto, com base na legislação vigente. As áreas de domínio da União abrangidas por servidão de passagem ou vias de acesso às praias e ao mar será objeto de cessão de uso em favor do Município correspondente.

Para assegurar o uso e o acesso às praias, deverá o poder público valer-se de uma das modalidades interventivas na propriedade privada, qual seja, a servidão administrativa que, para ODETE MEDAUAR ${ }^{245}$, “é um ônus real, instituído pela Administração sobre imóvel privado, para atendimento do interesse público, mediante indenização dos prejuízos efetivamente suportados".

Originária do direito civil, a servidão administrativa possibilita a partilha de certos atributos da propriedade (uso e fruição) com terceiros, visando aumentar a utilização do prédio dominante, implicando limitações ao serviente. Prevista no art. 40 do Decreto-lei $\mathrm{n}^{\circ} 3.365$, de 21.06.1941, restringe parcialmente o uso do bem, não decorrendo da sua instituição transferência do domínio ou da posse.

sua implantação, no prazo máximo de dois anos, contados a partir da publicação deste Decreto; e III nos imóveis rurais, condomínios e quaisquer outros empreendimentos à beira mar, o proprietário será notificado pelo Poder Público Municipal, para prover os acessos à praia, com prazo determinado, segundo condições estabelecidas em conjunto com o órgão ambiental. $\S 2^{\circ}$ A Secretaria do Patrimônio da União, o órgão ambiental e o Poder Público Municipal decidirão os casos omissos neste Decreto, com base na legislação vigente. $\S 3^{\circ}$ As áreas de domínio da União abrangidas por servidão de passagem ou vias de acesso às praias e ao mar serão objeto de cessão de uso em favor do Município correspondente. $\S 4^{\circ}$ As providências descritas no $\S 1^{\circ}$ não impedem a aplicação das sanções civis, administrativas e penais previstas em lei.

245 Direito administrativo moderno, p. 382. 
FLORIANO DE AZEVEDO MARQUES NETO ${ }^{246}$, ao aludir à distinção existente entre as diversas modalidades de servidão, ressalta a existência de elementos comuns: “(i) implica a subtração de uma utilidade intrínseca a um bem em favor da sua incorporação a outro acervo patrimonial, correspondente a outro bem ou a uma atividade; (ii) não implica a assunção, pelo beneficiário, do domínio da coisa serviente, pois que ela recai sobre uma utilidade, é dizer, sobre uma parcela do feixe de direitos de uso e gozo subjacente à propriedade; (iii) uma vez instituída, ela se traduz num direito real, oponível face a terceiros e independente de quem seja o seu titular".

No mesmo estudo, aponta o autor os elementos distintivos da servidão administrativa, a saber, de ser instituída em favor de uma utilidade pública e não de um bem; de ser instituída por força de lei, que preveja as situações de sujeição da propriedade particular ao regime de servidão. $^{247}$

O acesso não pode subordinar-se ao de alguns poucos, sob o manto distorcido do invocado direito de propriedade, balizado pelo cânone constitucional da função social (art. 5, XXIII da Carta de 1988). Esta é a posição do Excelso Pretório no RE 94.253, julgado em 12.11.82, ainda sob a égide da Carta anterior, sendo relator o Ministro Oscar Corrêa.

246 A servidão administrativa como mecanismo de fomento de empreendimentos de interesse público, Revista de Direito Administrativo, vol. 254, mai.-ago. 2010, p. 120.

247 Idem, p. 122. 
Exceção feita às áreas de interesse da segurança nacional ou protegidas por legislação específica, descabe qualquer tentativa do particular em vedar o acesso da população à praia ou ao mar, seja por terra, mar, ou ainda pelo ar.

Dessa forma, a instituição e a manutenção de servidão de passagem à praia ${ }^{248}$, com todas as suas implicações legais, ou a remoção de obstáculos que dificultem o acesso, será providência

248 Fechamento de acesso a ruas que interligam lotes e conduzem à orla marítima - Loteamento Legalidade de ato da Prefeitura Municipal - Remoção de obstáculos que impediam o livre acesso Inconstitucionalidade inocorrente da Lei Municipal $n^{0}$ 557/79, de Ubatuba - Direito à utilização de bem público de uso comum do povo assegurado - Recurso extraordinário não conhecida. (STF, RE 94253/SP, 1a Turma, Rel. Min. Oscar Corrêa, j. 12.11.1982). No mesmo sentido: TJSP, AC 81.356-5, Guarujá, Rel. Scarance Fernandes, j. 21.09.1999.

Restrição de acesso à praia - Loteamento - Remoção das construções - Desnecessidade. Constatada que as demais determinações impostas ao loteamento, tais como a colocação de placas esclarecendo que é livre 0 acesso à praia por aquela via e a proibição de novas construções que visem restringir tal passagem, por si só, tem o condão de satisfazer ao desiderato perseguido pelo Ministério Público Federal de garantir o acesso ao mar, revela-se desnecessária a imposição dirigida à remoção das construções efetuadas (TRF 2 - AG 150649 - 2006.02.01.0127109, TE, Rel. Des. Fed. Marcelo Pereira, j. 14.04.2009, trânsito em julgado em 15.06.2009).

Acesso à praia - Impedimento não configurado - Realização de benfeitorias - Inexistência de ilegalidade. As benfeitorias realizadas no referido loteamento visam tão-somente garantir a segurança dos moradores e proprietários locais, não restringindo o acesso à praia. A administração das vias públicas locais é assunto afeto às atribuições da Municipalidade, pelo que, uma vez apresentado projeto de urbanização que, aparentemente, não restringe o acesso à praia, não há ilegalidade a ser afastada (TRF 2 - AG 149795 - 2006.02.01.0112313, T7, Rel. Des. Fed. Ricardo Regueira j. 14.02.2007).

Transformação em condomínio fechado - Ipanema Itanhaém - Lei Municipal autorizadora - Concessão de uso - Transferência da manutenção, conservação e realização de serviços públicos - Construção de portões e cancelas - limitação aos cidadãos. O periculum in mora inverso, a seu turno, decorre da iminente possibilidade de execução provisória do acórdão recorrido, o qual ensejará a demolição dos muros e portarias que circundam o loteamento 'Balneário Santista', denominado de Condomínio 'Ipanema Itanhaém', bem como a demolição das construções realizadas na Av. Beira Mar, as quais foram erigidas há mais de 17 (dezessete) anos, ocasionando, inclusive, a descontinuidade da prestação de serviços indispensáveis, notadamente no que pertine aos serviços de vigilância; segurança e limpeza, realizados a expensas dos condôminos (STJ - MC 15726/SP - 2009/0124772-0, T1, Rel. Min. Luiz Fux, j. 20.04.2010).

Acesso da população à praia obstado. Deve ser indeferido o requerimento de liminar no que pertine à determinação de remoção de guarita, da cancela e das cercas existentes no local, não apenas em decorrência da segurança existente no referido condomínio, mas principalmente devido ao grande risco de irreversibilidade que tal determinação poderia causar no estado de fato existente na localidade. Ademais, há indicação de que a Municipalidade está prestes a providenciar a concretização de servidores de modo a permitir mais facilmente o acesso da população à praia e ao mar na localidade. Devem, no entanto, ser mantidas as determinações de remoção de placas e cartazes que restrinjam ou busquem restringir o acesso à praia e ao mar da região, assim como de não se construir, edificar ou 
de que o poder público não poderá se furtar, a fim de garantir o acesso livre, gratuito, efetivo e desembaraçado à praia ou ao mar, sob pena de restar inócua tal garantia. Na hipótese das praias localizadas nas ilhas, ainda que essas ilhas não sejam públicas, suas praias o são, sendo assegurado o seu acesso. ${ }^{249}$

dar continuidade à edificação ou qualquer outra ação tendente a restringir ou impedir o livre acesso à praia e ao mar; de colocação de placas nas principais vias de acesso ao loteamento com a informação de que é livre o acesso à praia e ao mar através da via pública existente no condomínio (TRF 2 - AG 148913 - 200602010092880, T8, Rel. Des. Fed. Guilherme Calmon, j. 21.11.2006 - trânsito em julgado em 23.02.2007).

Plataforma marítima - Tramandaí, Capão da Canoa e Cidreira - Ação civil pública - Bens de uso comum do povo - Alegada violação do art. 5ํ, XXXVI, da CF/88 - Inocorrência - Licença expedida pelo Ministério da Marinha que não é ato hábil a legitimar a utilização do bem, consistente em um 'nada a opor'. Ao Ministério da Marinha cabe, precipuamente, o exercício do poder de polícia quanto à segurança da navegação, sendo incompetente para fornecer qualquer autorização para construção em bem da União. Plataformas de pesca construídas sobre a praia, em total desacordo com as normas assecuratórias do livre usufruto do bem como coisa comum ao povo, sem que se permita qualquer obstáculo, seja ao acesso a praia ou ao que a ela venha a ser pelo homem agregado, violando ainda normas ambientais de proteção da Zona Costeira e do ecossistema marinho da plataforma continental. As plataformas foram irregularmente edificadas em área de domínio útil da União, afetadas ao uso comum do povo. São, portanto, benfeitorias úteis que se incorporam ao imóvel, e seguem a mesma qualificação jurídica: são elas mesmas bem de uso comum do povo e sua utilização por particulares deve seguir as regras do direito administrativo. Ademais, as rés não buscaram obter permissão, autorização ou concessão de uso, o que nem mesmo seria possível em face da precariedade das primeiras com o caráter definitivo da obra e a necessidade de se comprovar o interesse público no caso da concessão. Não há nenhum ato administrativo, legal ou não, a legitimar a utilização do bem de uso comum por particulares. E justamente por isso demonstra-se também infundada a alegação de prescrição ou decadência: porque não se alega nulidade ou anulabilidade de ato algum. Assim, só restaria às rés alegação de prescrição aquisitiva, que sabidamente não se aplica a bens públicos (TRF 4르. AC 04.01.019496-8, 3ㄹ Turma, Rel. Des. Fed. Carlos Eduardo Thompson Flores Lenz, j. 11.06.2002). No mesmo sentido:TRF4, AG 91.04.13982-8, $1^{\text {a }}$ Turma, Rel. Des. Fed. Paim Falcão, j. 22.04.1993.

249 É conveniente trazer à baila transcrição de Wallace Paiva Martins Júnior a respeito da vedação do acesso à praia ou de sua inexistência: "A lesão, em casos tais, agride toda uma comunidade indeterminada, desde o morador da mesma cidade até o turista vindo dos mais longínquos confins, porque, em síntese, todas são detentores do direito subjetivo público de observância geral das normas jurídicas de caráter urbanístico, de fruição universal dos bens públicos de uso comum do povo, de indisponibilidade do patrimônio público social. Em primeiro lugar, observe-se que as normas supramencionadas são urbanísticas, e, portanto, de ordem pública. Essa característica peculiar obriga os loteamentos de incorporações anteriores à Lei 7.661/1988 (art. 10) a adaptarem-se aos seus preceitos, em homenagem ao interesse público, suportando o particular ônus dessa exigência em prol da coletividade. Em segundo lugar, a existência dessas vias de circulação, inclusive as de acesso à praia, constituíam exigência do Decreto- lei $n^{\circ}$ 58/37 (art. 1ํinc. I e II § $4^{\circ}$ ) que ressaltava 0 caráter público delas com a inscrição (art. $3^{\circ}$ ). Ou seja, os loteamentos feitos sob a vigência desse diploma legal atribuíam ao domínio público as vias de circulação constantes da planta, após a inscrição. Referida exigência, com os mesmos atributos, consta, também, da Lei ํo 6.766/79 (art. 4o inc. I, § 1o e 22), no qual se manifestava impossível sob a égide de ambos os diplomas legais que se atribuísse domínio privado às vias de circulação, ou comunicação, inclusive as de acesso à praia" (Praças e praias públicas. Justitia, n. 168, out-dez. 1994, p. 70-89). 
A questão recebe proteção constitucional em Cartas Estaduais como o art. 285 da Constituição do Estado de São Paulo ${ }^{250}$ e o art. 214, IX, da Constituição do Estado da Bahia. 251

Cabe aqui breve alusão ao tratamento dispensado à matéria pelo direito estrangeiro.

Na Espanha ${ }^{252}$, a Ley de Costas da Espanha - Ley 22 de 28.07.1988, consagra o princípio da liberdade de acesso ao domínio público marítimo-terrestre, ou seja, ao mar e suas margens (art. 31.1). Repudia a privatização das praias, garante o acesso público a todas as instalações objeto de concessão de obra ou serviço público (art. 33.2). A lei espanhola afigura-se, de resto, como um modelo coerente em termos da aplicação do regime do domínio público marítimo às margens do mar. $\mathrm{O}$ art. 60 restringe a ocupação das faixas costeiras às atividades que não possam ter outra localização.

O direito francês também prevê a instituição de servidão de passagem para garantir o livre acesso à praia. BERNARD DROBENKO explica que o direito francês prevê ainda dois tipos de servidões administrativas que asseguram o acesso à praia, com as exceções por razões de

250 Art. 285 - Fica assegurado a todos livre e amplo acesso às praias do litoral paulista. \& 1으 Sempre que, de qualquer forma, for impedido ou dificultado esse acesso, o Ministério Público tomará imediata providência para a garantia desse direito. $\S 2^{\circ} \bigcirc$ Estado poderá utilizar-se da desapropriação para abertura do acesso a que se refere o 'caput.'.

251 Ostado e Municípios obrigam-se, através de seus órgãos da Administração direta e indireta a: (...) garantir livre e franco acesso às praias, proibindo-se qualquer construção particular, inclusive muros, em faixa de, no mínimo, 60 metros, contado a partir da linha da preamar máxima”.

252 Problemas de Ordenación territorial y urbanístico en el litoral survalenciano: Consideraciones sobre planeamiento, conservación de costas y promocion del turismo residencial. Informe apresentado na XIV reunião de estudos regionais, Málaga, 1988. Ramón Martín Mateo y J. Fernando Vera Rebollo, Revista de Derecho Urbanístico, jul/ago/set., no 114, ano XXIII, p. 642-643; Aspectos urbanísticos de la protección del território litoral, Revista de Derecho Urbanístico, Juán Jesús Trapero, , no 117, mar.-abr. Año XXIV, p. 53-64. 
segurança ou proteção ambiental: a servidão de passagem longitudinal à praia, imposição de ordem pública instituída por imperativo de segurança, e a transversal, constituída após consulta pública, quando não houver acesso à praia a menos de 500 metros. $^{253}$

Destarte, a garantia de acesso à praia constitui providência tutelada também no direito estrangeiro, salientando que no caso brasileiro a atuação municipal se dá de forma preponderante pela instituição e manutenção de servidão de passagem ou pela remoção de obstáculos que impeçam ou dificultem o aludido acesso.

\subsection{A atividade turística como novo ciclo de ocupação do ambiente costeiro urbano}

Primeira região do território brasileiro a ser ocupada ${ }^{254}$, a zona costeira concentra a maior parcela da população e da atividade econômica, responsável pelo escoamento da produção das terras interiores. Nas últimas décadas novos ciclos surgiram decorrentes do incremento da atividade turística, hoje considerada como relevante fator econômico, e das novas descobertas de jazidas de petróleo e gás.

253 Cit., 82-83. Ver também: Raphael Romi, ao comentar o art. 160-6 do Código de Urbanismo francês e lei de 31.12.1976, indica a instituição de servidão de passagem de 3 metros de largura, exceção feita a razões de segurança, defesa nacional e proteção ambiental que obedecerão a disposições particulares (Droit et administration de l'environnement, Paris, Montchrestien, 1997, 2 ed., p. 330-331). Jacqueline Morand-Deviller alude à instituição de servidão de passagem pela lei de 31.12.1976 (Cours de droit administratif des biens, cit., p.169).

254 Cf. supra 1.1.2. 
O turismo ${ }^{255}$ na zona costeira é atividade econômica, cultural e psicológica, de grande relevância, propiciada muitas vezes pela existência do mar, justificando-se a criação de Áreas Especiais $^{256}$ e de Locais de Interesse Turístico, regido pela Lei $n^{\circ}$ 6.513, de 22.12.1977257, regulamentada pelo Decreto n ${ }^{\circ} 86.176$, de 06.07.1981.

A indústria do turismo está entre os setores com maior desenvolvimento nas últimas décadas.

Emprega e qualifica mão de obra, consolida mercado consumidor interno e atrai divisas para o país, embora seja ainda embrionária no caso brasileiro se comparada a países como Estados

255 "Turismo é a soma de relações e serviços resultantes de uma mudança voluntária para uma residência temporal, não motivada por razões de negócios ou profissionais. Sendo o objeto do turismo uma localidade, deve haver nela um conjunto de atrativos, culturais ou naturais, que justifiquem esse deslocamento" (Rita Mendonça, Turismo ou meio ambiente - uma falsa opção, in Turismo -impactos socioambientais, Amália Inês Geraiges de Lemos (Org.), São Paulo, HUCITEC, 1996, p. 19-25).

256 Para José Afonso da Silva: "Serão declaradas Áreas Especiais de Interesse Turístico Prioritárias as áreas de alta potencialidade turística que devam ou possam ser objeto de planos e programas de desenvolvimento do turismo, em virtude de: a) ocorrência ou iminência de expressivos fluxos de turistas e visitantes; b) existência de infraestrutura turística e urbana satisfatória, ou possibilidade de sua implementação; c) necessidade da realização de planos e projetos de preservação e recuperação dos Locais de Interesse Turístico nelas incluídos; d) realização presente ou iminente de obras públicas ou privadas que permitam ou assegurem o acesso à área, ou criação da infraestrutura mencionada na alínea 'b'; e) conveniência de prevenir ou corrigir eventuais distorções do uso do solo causadas pela realização presente ou iminente de obras públicas ou privadas, ou pelo parcelamento e ocupação do solo. Serão conhecidas como de Reserva Turística as áreas de elevada potencialidade turística, cujo aproveitamento deva ficar na dependência: a) da implantação dos equipamentos de infraestrutura indispensáveis; b) da efetivação de medidas que assegurem a preservação do equilíbrio ambiental e a proteção ao patrimônio cultural e natural ali existentes; c) de providências que permitam regular, de maneira compatível com a alínea precedente, os fluxos de turistas e visitantes e as atividades, obras e serviços permissíveis" (Direito urbanístico, p. 387-388).

257 De acordo com o art. 3o da Lei oㅜ 6.513, de 20.12.1977: áreas especiais de interesse turístico são trechos contínuos do território nacional, inclusive suas áquas territoriais, a serem preservados e valorizados no sentido cultural e natural, e destinados à realização de planos e projetos de desenvolvimento turístico. $\mathrm{O}$ art. 11 prevê a instituição, por decreto do Executivo Federal em atendimento à proposta do Conselho Nacional de Turismo, de Áreas Especiais de Interesse Turístico, para fins de elaboração e execução de planos e programas destinados a promover o desenvolvimento turístico, assegurar a preservação e valorização do patrimônio cultural e natural, estabelecer normas de uso e ocupação do solo, e orientar a alocação de recursos e incentivos necessários. Assim, essas áreas transformam-se em instituição jurídica, passando a ser objeto de plano e programas especiais de urbanismo, com fins turísticos, classificadas em duas categorias: Prioritárias e de Reserva. Os art. 20 a 23 da mesma lei disciplinam a celebração de convênios da EMBRATUR com órgãos e Entidades estaduais e municipais. 
Unidos, França, Itália, Inglaterra e Espanha, que têm no turismo importante fonte de recursos, sendo a principal no caso espanhol.

Não constitui exagero afirmar que a zona costeira é região destinada, em sua totalidade, à atividade turística, pois o ambiente litorâneo é propício à prática de esportes e ao lazer em geral, apresentando ainda expressivo conjunto de paisagens notáveis.

O desenvolvimento sustentável da indústria do turismo constitui desafio a ser enfrentado por países com expressivo grau de desenvolvimento econômico e diversidade de suas matrizes, revelando-se dramático em regiões, muitas vezes pequenos arquipélagos, que têm no turismo a única fonte de desenvolvimento econômico. ${ }^{258}$

O fato é que o desenvolvimento da atividade turística deflagra o processo de urbanização das regiões até então intocadas, ou a reurbanização de áreas já habitadas, dando início ao processo de especulação imobiliária que, ao valorizar novas áreas, produz inevitável impacto ambiental. O aterro de mangues e lagunas, a eliminação de áreas de florestas originais, a ocupação de dunas e a construção sobre altas declividades são frequentes em todo o litoral

258 Ao tratar do turismo na zona costeira, Mariana Almeida Passos de Freitas assevera: "O litoral é identificado como espaço para o lazer, o que torna ainda mais valorizadas as regiões bem preservadas e próprias para o ecoturismo (...) Desse modo, o turismo é uma das principais atividades econômicas de diversas cidades costeiras. Algumas, principalmente as pequenas, nele têm a única atividade econômica, inclusive com reflexos negativos na área imobiliária: a expansão dos loteamentos e a crescente demanda de áreas disponíveis favorece o surgimento de construções irregulares, muitas vezes realizadas sem a devida autorização do Poder Público. O turismo é uma atividade importantíssima para as cidades litorâneas, mas sua gestão deve ser realizada de maneira adequada para que se torne fonte essencial de revitalização econômica. O ideal é que seja realizado de forma sustentável, sempre com preocupação em relação aos bens socioambientais. Deve-se evitar que as cidades litorâneas cresçam de forma caótica e engendrem dessa forma graves problemas sociais e ambientais" (cit., p. 26-27). 
brasileiro, ocasionando o declínio da qualidade de vida e o comprometimento dos diversos ecossistemas que constituem a diversificada zona costeira nacional. ${ }^{259}$

RITA DE CÁSSIA ARIZA DA CRUZ adverte para os riscos do crescimento da indústria do turismo no Brasil, especialmente no Nordeste ${ }^{260}$, pois, considerado o baixo grau de desenvolvimento econômico daquela região, em que pobreza e miséria compõem parte significativa do quadro social, o turismo tem sido visto como alternativa viável em busca do desenvolvimento e da superação dessas deficiências: “O imediatismo que tem caracterizado o desenvolvimento da atividade, porém, compromete os resultados ao longo do processo, instruindo a maximização de benefícios e levando a superação de impactos negativos. O país não tem tradição na elaboração de políticas para o turismo e daí o planejamento turístico vir acontecendo segundo planos estaduais e municipais, com pouca ou nenhuma orientação em escala federal. A inexistência de diretrizes em âmbito federal tem levado ao surgimento de políticas de turismo isoladas, ora institucionalizadas, ora não, constituindo a Região Nordeste exemplo claro dessa situação".

Nesse interessante trabalho a autora também diferencia o perfil do turismo nordestino daquele praticado no centro-sul (veranismo), pois enquanto neste grande parte dos investimentos em infraestrutura tem sido canalizado para a implantação de megaempreendimentos do tipo 'loteamento fechado' para segundas residências, naquele os investimentos têm se dirigido, majoritariamente, para a ampliação da rede hoteleira, devido, basicamente, a dois fatores:

259 Conferir: Bertha K. Becker. Levantamento e avaliação da política federal de turismo e seu impacto na região costeira. Brasília: Plano Nacional de Meio Ambiente, 1996; Doris Ruschmann. Turismo e planejamento sustentável: a proteção do meio ambiente. São Paulo: Papirus, 1997;

260 Políticas de turismo e construção do espaço turístico-litorâneo no Nordeste do Brasil, in Turismo impactos socioambientais, Amália Inês Geraiges de Lemos (Org.), p. 263-272. 
existência em muito menor escala que nas regiões Sul e Sudeste ${ }^{261}$ de demanda solvável capaz de arcar com os custos de manutenção de um imóvel de veraneio; distância dos principais polos emissores de turistas do país, localizados na Região Centro-Sul. ${ }^{262}$

Os inconvenientes do crescimento repentino e desordenado dos municípios costeiros podem superar os benefícios, pois o desmatamento, a degradação do solo e a poluição das águas são algumas consequências inevitáveis da ocupação da zona costeira, ante a necessidade de geração de empregos, construção de moradias e estruturas de lazer. ${ }^{263}$

A indústria do turismo, assim, provoca a deterioração ambiental de diversas formas, redução da biodiversidade, dilapidação dos recursos e problemas causados à saúde humana. As praias são o principal destino do turismo costeiro e a maior fonte de recursos de muitos países,

261 É importante ressaltar o Zoneamento Econômico Ecológico do Litoral Norte de São Paulo, região marcada pela diversidade de recursos naturais e intensa especulação imobiliária, decorrente da predominância do turismo veranista, agora às voltas com as atividades do pré-sal. O Grupo Setorial de Coordenação formado foi integrado por 24 membros, dos quais 8 representam o Governo do Estado, 8 representam os Municípios e 8 representam a Sociedade Civil Organizada. Embora tenha sido estabelecido por meio de um Decreto (Decreto $n^{\circ}=49.215 / 2004$ ), foi construído de forma participativa e consensual, na medida em que só foi editado depois de realizadas inúmeras reuniões técnicas e audiências públicas em todos os municípios da região, visando dirimir os conflitos e incorporar as propostas dos diferentes setores da sociedade civil e do poder local. Durante as discussões do zoneamento, um tema que polarizou foi o fato das atividades turísticas contemplarem variações que vão desde a implantação de pousadas, complexos hoteleiros, grandes estruturas de apoio à navegação, até as trilhas em Unidades de Conservação. Merecem destaque também as discussões em torno da especificidade do processo de ocupação do Litoral Norte, caracterizado pela presença de condomínios de alto padrão com baixa densidade demográfica. Outro tema dominante foi a questão da pesca artesanal e da agricultura de subsistência, tendo sido incorporadas as propostas dos representantes das entidades sindicais de enquadramento das zonas, visando proteger a atividade agrícola da crescente expansão urbana e das ações predatórias. Com relação à pesca, optou-se pela criação de uma zona destinada ao desenvolvimento da atividade pesqueira e a maricultura, da qual se excluía a pesca de arrasto e a industrial (Zoneamento Econômico Ecológico do Litoral Norte, Secretaria do Estado do Meio Ambiente - Coordenadoria de Planejamento Ambiental Estratégico e Educação Ambiental - 2005). 262 Idem, p. 266.

263 John Vernberg e Winona Vernberg lembram ser da natureza humana alterar o meio ambiente para dele retirar aquilo do que precisa e que, desta forma, o crescimento populacional ao longo da costa produzirá alterações inevitáveis, cujos impactos negativos frequentemente superam os positivos (The coastal zone: past, present and future, South Carolina, p. 65-66).

Formatado: Fonte: $10 \mathrm{pt}$, Português (Brasil)

Formatado: Fonte: $10 \mathrm{pt}$, Português (Brasil)

Formatado: Fonte: 10 pt, Português (Brasil) 
entretanto apenas boas praias atraem bilhões em divisas, praias degradadas possuem pouco valor. $^{264}$

Ademais, o ganho da atividade turística nem sempre é compartilhado pelas comunidades locais e pela maioria dos segmentos sociais, mesmo em países com desenvolvimento econômico consolidado, caracterizados pelo crescimento urbano planejado.

Alguns efeitos deletérios são relatados por JOHN VERNBERG e WINONA VERNBERG ${ }^{265}$ em estudo que aponta para o crescimento da pobreza e do desemprego entre 1980 e 1990, em Myrtle Beach e Grand Strand na Carolina do Sul, além do comprometimento da qualidade das águas costeiras, contaminação de lençóis freáticos, criação de empregos temporários, geração de empregos permanentes no setor de serviços com baixa remuneração, entre outros, tais como tempestades, inserção de novas espécies de plantas e animais, dragagem, elevação do nível da águas, etc.

RAPHAEL ROMI também observa que a atividade turística na zona costeira francesa aumenta a demanda por serviços, favorece a especulação imobiliária e compromete a proteção ambiental, e reconhece a necessidade de um 'ponto de equilíbrio' entre desenvolvimento econômico-turístico (que regulamenta a hotelaria e o camping, limita o turismo náutico, subordina a urbanização à realização de equipamentos de tratamento de e

264 John R. Clark, Costal zone management, p. 17.

265 The coastal zone, p. 71-72. 
evacuação de efluentes, etc.) e proteção do litoral, na lei de 03.01.1986, 07.01.1983 e Decreto de 20.09.1989. ${ }^{266}$

Na Espanha, ${ }^{267}$ no contexto de um planejamento tardio e extremamente flexível, o protagonista da realidade econômica é o turismo de massas, que progride no ritmo de crescimento das economias industrializadas e que só não supera a cada ano a cifra de visitantes, pelo condicionamento da oferta imobiliária tanto para o turismo nacional como para o estrangeiro. ${ }^{268}$

O diagnóstico levantado pelos autores pode ser perfeitamente aplicável à realidade brasileira, exceção feita à disponibilidade de imóveis ainda farta em algumas regiões brasileiras, considerando a inserção cada vez maior de significativas parcelas da população do mercado de consumo turístico, ao cotejo de dois elementos fundamentais e finitos, o solo e a água.

266 Droit et administration de l'environnement, p. 327.

267 Ainda em relação à rica experiência espanhola, da mesma forma aplicável ao contexto brasileiro, observa Pere A. Salva I. Tomas: "É impressionante o desenvolvimento do turismo de massas na região mediterrânea tem acarretado importantes consequências sobre o subsistema sociocultural preexistente, alterando 0 modo de vida e comportamentos da sociedade residente nas regiões receptoras, cuja velocidade dificulta sua absorção. Na maioria das regiões costeiras mediterrâneas, as atividades turísticas se estabeleceram sobre espaços rurais nos quais residia uma população caracterizada por hábitos tradicionais, nos quais a religião, a tradição e o conformismo político eram aspectos básicos e marcantes. Por isso, a aparição repentina de um grande número de turistas causou, inicialmente, um choque entre diferentes culturas que representavam diferentes modos de vida e comportamentos, provocando efeitos que alguns autores classificaram como etnicida, exterminador da cultura tradicional. De todo modo, cabe salientar que o processo de 'turistización' pode representar um papel parecido aos processos de industrialização e de urbanização nos países desenvolvidos, no que concerne à modernização da sociedede" (Las implicaciones socioculturales del turismo en el mar Mediterrâneo, p. 188-189).

268 Ramón Martin Mateo e J. Fernando Vera Rebolo asseveram: "Na verdade, a unidade básica de produção é a urbanização, empreendimentos residenciais, que determina um processo constante de modificação do uso do solo e de transformação da estrutura territorial, econômica, administrativa e demográfica, afetado atualmente por dois únicos fatores limitantes: o solo e a água" (Problemas de ordenación..., p. 14). 
Outra questão relevante, esta de competência do poder público municipal, é coleta e o tratamento de lixo, potencializado na zona costeira pelas características geográficas da região, propícia à contaminação por vírus e bactérias, vez que a água é o maior vetor.

Essa contaminação pode se dar seja pelo consumo de pescado, pelo lazer aquático, por dejetos de embarcações, pelo consumo de bebidas geladas, pela maior exposição do corpo à natureza, entre outros fatores. ${ }^{269}$

MARIA LUIZA MACHADO GRANZIERA observa que "Nessa área muitas pessoas buscam o lazer, propiciado pelas praias e paisagens notáveis. Nos meses de verão, as populações urbanas se multiplicam, gerando uma demanda de serviços de saneamento - coleta de lixo, água e esgoto - nem sempre atendida, causando a poluição das praias por coliformes fecais e atraindo vetores de doenças em função do esgoto não tratado e do lixo não recolhido. A pressão de condomínio de casas de lazer, ao longo de toda costa brasileira, é uma das causas de degradação ambiental. Paralelamente, as invasões de populações de baixa renda em áreas

269 A esse propósito, John Vernberg e Winona Vernberg observam: "A Bactérias e virus podem contaminar áquas abertas e estuarinas e, consequentemente, peixes, mariscos, ostras e seres humanos. Hoje este problema aparece com maior frequência em diversos pontos da zona costeira, decorrentes da agricultura, da urbanização, manuseio de fossas sépticas, tempestades e descargas de embarcações pequenas e de recreio, que acabam por expor a população à contaminação pelo consumo de pescado, prática de banho de mar, esportes náuticos e consumo de agua contaminada. A atividade turística realizada nessas comunidades sofre o impacto econômico da interdição das praias durante a alta estação" (cit., p 102-103). 
de preservação é outra realidade, que, embora seja consequência de problemas de cunho social, não deixa de causar danos ao ambiente."270

Conforme salienta CARMEM LÚCIA VERGUEIRO MIDAGLIA: "Esta preferência dos brasileiros manifestada normalmente pelas praias não se deve ao fato de inexistirem aqui outras áreas com grande potencial de atratividade tal como áreas montanhosas interessantes ou parques de águas quentes, estâncias hidrominerais etc. Eles são, de certa forma, mais dados a atividades de ação, procurando praticar esportes, influenciados pela mídia, que induz o culto ao corpo e à ascensão social através da compra de acessórios para essas atividades. Existe até modismo de praia especialmente criado para cada verão, cujo ápice coincide com o carnaval. Tal como acontece em áreas terrestres, também na água a mudança de usos de determinada zona costeira pode registrar alterações. Por exemplo, o uso de determinados equipamentos, tais como embarcações movidas a combustível (lanchas, jet-skies etc.) podem causar o afugentamento de espécies marinhas, através do intenso barulho e movimento das águas, afastando pequenos cardumes, mudando a cadeia alimentar, além do fato de existir a possibilidade do vazamento de óleo e gasolina na água. Alguns costões marinhos estão sendo muito visitados por mergulhadores, às vezes até organizados em pequenos grupos de excursão com a finalidade de pesca ou não, mas que seguramente afetam a harmonia local". ${ }^{271}$

O desenvolvimento de uma indústria turística rentável e sustentada na zona costeira, que atenda à demanda do progresso repentino que ocorreu no Brasil nas últimas décadas, acentuado com a inclusão de amplas parcelas da população nos setores médios, clama por

270 Direito ambiental, p. 576.

271 Turismo e meio ambiente no litoral paulista - dinâmica da balneabilidade nas praias, in. Turismo impactos socioambientais, Amália Inês Geraiges de Lemos (Org.), p. 32-56. 
investimentos em diversos segmentos: infraestrutura aeroportuária, rodoviária e hidroviária; instalações portuárias náutico-desportivas, parques aquáticos, marinas; saneamento básico; energia; telecomunicações; recuperação do patrimônio histórico; equipamentos e serviços; estudos e projetos de marketing; desenvolvimento de recursos humanos; segurança pública, entre muitas outras providências, algumas possíveis apenas pela percepção do poder público local.

Esse processo, se bem gerenciado e disciplinado por regramento jurídico apropriado, em um primeiro momento, trará benefícios às populações diretamente envolvidas, e, em médio prazo, a toda a economia nacional. Ademais, com as devidas cautelas, não há que se temer o incremento desse segmento econômico, ${ }^{272}$ sendo possível o desenvolvimento sustentável da região ${ }^{273}$, processo em que o município desempenha papel de maior relevo ${ }^{274}$, beneficiando-se ademais com a valorização imobiliária e consequente aumento de arrecadação. ${ }^{275}$

272 No âmbito do Projeto Orla, foram capacitados 180 gestores locais para incrementar a gestão integrada da orla dos municípios de Goiana, Tamandaré, Barreiros, Rio Formoso, Sirinhaém, São José da Coroa Grande e, especialmente, Cabo de Santo Agostinho e Ipojuca, em Pernambuco, com a elaboração de Portfólio com 4 projetos de alternativa Econômica para apoio ao turismo sustentável (Andrea Olinto, Djanira Gondim e Eliane Basto, Programa de Gerenciamento Costeiro: Experiência do programa em Pernambuco, in Gestão Costeira Integrada, no 5, 2006, p. 18-22).

Barros, Wallner-Kersanach e Wasserman, também destacam a importância da participação da comunidade, não apenas para identificar os problemas ambientais, mas principalmente na construção de Planos de Ação para o desenvolvimento da região de Saquarema, sendo a construção de propostas de atividades sustentáveis, etapa prioritária nos planos para as Zonas Costeiras onde o veraneio está estabelecido, sendo o principal gerador de emprego. Salientam que um novo modelo de desenvolvimento local necessita ser construído visando a atender as necessidades e os anseios da comunidade, na geração de renda e emprego respeitando as vocações naturais, sem acarretar mais danos ao meio ambiente e à cultura local. Proposta de um plano de ação para o gerenciamento integrado da zona costeira no Município de Saquarema-RJ (idem, p. 25-33).

273 Área de preservação permanente - População nativa caiçara - Preservação ambiental e proteção à dignidade da pessoa humana - Decisão interlocutória que limita o número de turistas no local Possibilidade - Recurso não provido. A limitação do número de campistas na Praia do Aventureiro, de modo a não se sacrificar qualquer dos valores em conflito, busca, por um lado, a preservação ambiental, e, por outro, a dignidade da pessoa humana, já que os moradores sobrevivem, além da pesca, atualmente em estado de escassez, do turismo. Não se pode retirar da comunidade local, de forma como se pretende, um dos seus principais meios de subsistência (TJRJ, Al 002.05684 - 
Nesta quadra, de acordo com as circunstâncias e peculiaridades do caso concreto, as seguintes recomendações devem ser $\operatorname{observadas}^{276}$ : evitar grandes concentrações turísticas e urbanização excessiva em uma determinada região; integrar o turismo ao meio ambiente mediante uma arquitetura adaptada; preservar e valorizar o patrimônio histórico, natural e cultural; promover a participação das comunidades locais; promover a aquisição de consciência pelas populações locais e pelos turistas a respeito da necessidade de proteger as riquezas naturais e o patrimônio. ${ }^{277}$

0017362-06.2006.8.19.0000 / 2006.002.04375, 1ª Câmara Cível, Rel. Des. Maldonado de Carvalho, j. 28.06.2006).

274 LC no 111, de 01.02.2011, que dispõe sobre a Política Urbana e Ambiental do Município, institui o Plano Diretor de Desenvolvimento Urbano Sustentável do Município do Rio de Janeiro; Lei no 8.167, de 2012, que dispõe sobre a Lei de Ordenamento do Uso e da Ocupação do Solo do Município de Salvador; Lei no 2.193, de 1985, que dispõe sobre o zoneamento, o uso e a ocupação do solo nos Balneários da llha de Santa Catarina.

275 Riviera São Lourenço se destaca como uma ilha de excelência que abriga moradias de luxo de turistas de alta renda, um enclave que denota o quão distante Bertioga está do patamar lá alcançado. O bairro ocupa $4,5 \mathrm{~km}$ de praia contando com 10 a 12 mil residentes (flutuantes ou não), com planos de expansão para 105 mil. O diferencial, comparada a outros empreendimentos imobiliários, reside no sistema interno de gestão, de cunho técnico, inspirado nos Conselhos de Gerência de Cidades, encontrados em países como Canadá, Austrália e Nova Zelândia, com gerenciamento do tratamento de água e esgoto; coleta, separação e destinação final do lixo; segurança interna; limpeza das ruas; trabalho de educação ambiental como os funcionários (mesmo em baixa estação gera cerca de 5 mil empregos diretos para Bertioga). É assegurado o livre acesso às praias, espaçamento entre os prédios de modo a garantir a brisa e livre circulação (Diagnóstico Urbano Socioambiental - Município de Bertioga - Bases das Informações até 2012 - Revisão Março de 2013 - Convênio Petrobrás Instituto Polis - Relatório nª 6, pp. 81/91). Há, todavia, o risco de movimento emancipatório privando Bertioga da receita fiscal expressiva do empreendimento, bem como eventual abandono dos proprietários em futuro remoto deixando a população sem os empregos, fenômeno típico do turismo baseado em grandes condomínios para segunda residência.

Experiências bem sucedidas, destinadas a mitigar os efeitos negativos da urbanização decorrente do incremento da importante indústria do turismo, podem ser encontradas na Província espanhola de Cadiz (Guía de buenas práticas para la gestión de los recursos del litoral de la Provincia de Cádiz. Convenio de Colaboración: Disputación Provincial de Cádiz y Universidad de Cádiz. Disputación de Cádiz Servicio de Publicaciones, 2002, p. 27-30).

276 Maria Inez Pagani, Alexandre Schiavetti, Maria Eugênia Bruck de Moraes, Fábio Henrique Torezan, As trilhas interpretativas da natureza e o ecoturismo, in. Turismo - impactos socioambientais, Amália Inês Geraiges de Lemos (Org.), p. 151-163.

277 A guisa de exemplo da problemática em torno da relação da atividade turística com a proteção ambiental, em São Paulo, a Lei de Zoneamento Costeiro do Litoral Norte define que apenas uma zona tampão de 50 metros a partir do Parque Estadual da Serra do Mar será determinado pelo Estado. As demais zonas serão definidas pelos Planos Diretores Municipais. Assim, o Zoneamento EcológicoEconômico da região está distribuído em cinco Zonas: Z1 - Uso restrito para preservação e 
Cumpre ainda apontar o alto grau de qualificação profissional que a indústria do turismo agrega na promoção cultural do trabalhador, com o domínio de idiomas no contato com outras culturas, com o incentivo a novas praticas na gastronomia, e com a consequente inserção global, no contato com modernas tecnologias, não se olvidando ainda sua natureza de “indústria limpa", se comparada às demais atividades. ${ }^{278}$

Para a obtenção de resultados positivos, o Município deverá lançar mão dos instrumentos previstos no art. $4^{\circ}$ da Lei $\mathrm{n}^{\circ} 10.257$, de 10.07.2001, do exercício do poder de polícia do Município em conjunto com outros meios menos intrusivos, da participação no sistema de gerenciamento costeiro especialmente pelo Projeto Orla, bem como atuar em parceria com o setor privado e a com a comunidade local.

conservação, pesquisa e educação ambiental, ecoturismo, pesca artesanal e poucos tipos de ocupação humana. No lado marinho, é liberado o uso para planos de manejo sustentado; Z2 - Permite ocupação humana que mantenha as características da região, mineração e manejo sustentado. $\mathrm{Na}$ área marítima (mar e mangue), libera pesca artesanal e aquicultura e atividades de recreação de baixo impacto; Z3 - Libera usos anteriores e permite ainda a agropecuária e a sericultura. Na zona marinha, permite pesca industrial, marinas e garagens para embarcações; Z4 - Compreende as atuais construções e onde a vegetação já foi praticamente destruída ou alterada. Permite construções de imóveis com restrições. Na zona marinha, além dos usos anteriores, prevê a existência de estaleiros; Z5 - Prevê quase todo o tipo de atividade, inclusive industriais (fábrica, comércio e serviços), turísticas (hotéis e agências de turismo) e aeroportuárias (aeroporto, sistema viário, marina e porto). No mar e nos canais, como o de São Sebastião, já se percebe o desaparecimento de espécies.

278 A 'cadeia de produção' turística pode ser definida como o conjunto das empresas e dos 'elementos materiais e imateriais' que realizam atividades ligadas ao turismo, como procedimentos, ideias, doutrinas e princípios ordenados, divididas nas seguintes áreas: agências de viagens; transporte; alojamento; alimentação; atividades recreativas e desportivas; comércio. Caberá ao plano local a disciplina de suas peculiaridades, como a Lei ํㅡ 2.686, de 19.12.2006 que dispõe sobre a revisão do Plano Diretor do município de Balneário de Camboriú, cujo art. 15, ao detalhar os elementos de sua política de turismo, acrescenta ainda, aos itens mencionados, a terceira idade (item g), o naturismo (item d) e Místico-religioso (item n). 


\subsection{Impactos da extração de petróleo e gás}

As recentes descobertas de jazidas de gás e petróleo na camada do pré-sal ${ }^{279}$, situada na Bacia de Santos, a par das atividades petrolíferas já desenvolvidas na Bacia de Campos (RJ), intensificarão as atividades industrial e de serviços e acentuarão o processo de urbanização, bem como agravarão os riscos ambientais diante da possibilidade de eventuais vazamentos, seja nos poços em atividade ou no transporte do produto. ${ }^{280}$

A questão merece ser enfrentada. Não obstante previsão constitucional assegurando à União a propriedade dos recursos minerais, petróleo e gás natural ${ }^{281}$, os impactos da atividade de exploração, transporte, refino e distribuição no meio urbano/ambiental local exigirão providências que irão onerar os Municípios, seja pelo atendimento de demandas sociais por moradia $^{282}$, emprego, transporte, saneamento e urbanização, ou pelo exercício do poder de

279 A Bacia de Santos está localizada numa área de $352 \mathrm{mil} \mathrm{km}^{2}$, se estende pelo litoral sul do Estado do Rio de Janeiro, passando por toda a costa de São Paulo e do Paraná e pelo norte do litoral de Santa Catarina.

280 Sobre os riscos ambientais da exploração da atividade na região e as medida atinentes à sua mitigação, ver Mitigação dos riscos na exploração e produção de petróleo e gás na Bacia de Santos, Luis Antonio de Mello Awazu et alii,. Conferir também Governanca ambiental e gerenciamento social dos riscos, Ícaro A. da Cunha e Luciano A. Prates Junqueira, in Alcindo Gonçalves e Gilberto M. A. Rodrigues, Direito do petróleo e gás, Santos, Leopoldianum, 2007, p. 141-149 e 151-163.

281 Constituição Federal, art. 20. São bens da União: (...) I - os recursos minerais, inclusive os do subsolo; (...) \& 1․ É assegurada, nos termos da lei, aos Estados, ao Distrito Federal e aos Municípios, bem como a órgãos da administração direta da União, participação nos resultados da exploração de petróleo e gás natural, de recursos hídricos para fins de geração de energia elétrica, e de outros recursos minerais no respectivo território, plataforma continental, mar territorial ou zona econômica exclusiva, ou compensação financeira por essa exploração.

282 Uma preocupação levantada por entrevistados de entidades da sociedade civil e de moradores, dizem respeito à especulação imobiliária e a elevação do custo dos imóveis motivadas pelos investimentos da Petrobras em torno ao Pré-sal, que está gerando um sentimento de 'expulsão' dos vicentinos da cidade - sensação similar amplamente manifestada na cidade de Santos. Como polo comercial regional, há também o temor de que o aumento excessivo de consumidores e moradores resulte na elevação dos preços na cidade, que não se vê com estrutura para colher eventual afluxo de pessoas que aportarão na Baixada (Diagnóstico Urbano Socioambiental - Município de São Vicente Bases das Informações até 2012 - Revisão Março de 2013 - Convênio Petrobrás Instituto Polis Relatório $n^{\mathrm{a}}$ 6, p. 63-64).

Em relação a Santos, o espaço limitado seria agravado pelo fato de ser uma cidade estruturada e em franca expansão econômica, dotada de uma rede de infraestrutura e de serviços bem desenvolvida, o que alavancaria a especulação imobiliária, desencadeando um processo inflacionário do mercado 
polícia fiscalizador ${ }^{283}$, visando assegurar a manutenção ou mesmo preponderância do interesse local, inclusive pelo manejo de receitas provenientes da mencionada atividade.

Vale lembrar que esse tipo de exploração requer adequada infraestrutura de operações e instalações de apoio logístico ${ }^{284}$, tanto no mar como em terra (plataformas, redes de dutos, bases de apoio, tanques de armazenamento, emissário para o descarte de águas tratadas, instalações destinadas ao abastecimento e manutenção de navios e aeronaves), com reflexos na atividade econômica e de serviços privados e públicos da região, bem como a necessidade de aumento da malha urbana para acomodar o crescimento populacional. ${ }^{285}$

imobiliário, a verticalização e todas as consequências daí decorrentes como o impacto nos serviços públicos de coleta de lixo, abastecimento, sistema de tráfego, etc., vislumbrando do processo de urbanização excludente em curso um futuro de uma cidade de classe média alta (Diagnóstico Urbano Socioambiental - Município de Santos - Bases das Informações até 2012 - Revisão Março de 2013 Convênio Petrobrás Instituto Polis - Relatório nª 6, p. 62).

283 Cf. supra 3.1.

284 As operações na Bacia de Santos serão atendidas por bases de apoio aéreas localizadas nas cidades de Itanhaém (SP), Navegantes (SC) e Rio de Janeiro (RJ); o apoio portuário a partir do Rio de Janeiro (RJ) e Itajaí (SC). Outras duas bases logísticas, que contemplam áreas de porto, aeroporto, armazenagem, laboratórios e Centro de Defesa Ambiental estão em fase de estudos, sendo uma em Itaguaí (RJ) e outra em Guarujá (SP). As instalações para a Unidade de Operações de Exploração e Produção da Bacia de Santos - UO-BS está instalada em sete endereços na cidade de Santos. A Unidade de Tratamento de Gás Monteiro Lobato - UTGCA, em Caraguatatuba (SP), completa o grupo de instalações terrestres da unidade. Uma sede definitiva para a Unidade da Bacia de Santos está em construção no bairro do Valongo, em Santos, com três torres com capacidade para cerca de duas mil pessoas cada uma. Não há qualquer trecho do litoral brasileiro, de Santa Catarina ao Espírito Santos que ficará imune ao impacto causado pela exploração do Pré-Sal, considerando incremento do sistema viário (duplicação de rodovias Tamoios, Rio-Santos), ferroviário, bases de apoio marítimo (supply houses), estaleiros, instalações para armazenagem e manutenção, expansão do setor de serviços, comércio, hotelaria e expansão imobiliária, especialmente nas cidades-dormitórios que surgirão a partir da farta oferta de estoque de terreno, como Praia Grande, Ubatuba e a Costa Sul de São Sebastião neste Município a costa Norte e o Centro vivem em função do porto (Diagnóstico Urbano Socioambiental - Município de Santos - Bases das Informações até 2012 - Revisão Março de 2013 Convênio Petrobrás Instituto Polis - Relatório nª 6, p. 107-109)

285 Fenômeno ocorrido na Bacia de Campos, em especial no município de Macaé, e agora em franca instalacão no litoral paulista, especialmente nos municípios de Santos, Caraguatatuba (centro de beneficiamento de gás) e São Sebastião, cuja expansão do porto já está em andamento, aumento a capacidade de atracação simultânea de 4 para 18 navios, na maioria petroleiros, além de terminal de contêineres com capacidade para receber 240 mil contêineres por mês, com a duplicação da rodovia dos Tamoios que passará a receber cerca de 4.000 caminhões por dia. 
MARIA LUIZA MACHADO GRANZIERA lembra que "pelo litoral escoam-se as riquezas brasileiras através de estradas e portos. As atividades de extração de petróleo e gás se intensificam na costa brasileira, muitas vezes próximo ao litoral. Da mesma forma, muitos polos petroquímicos e cloroquímicos situam-se próximos do mar, além das usinas nucleares de Angra 1 e Angra 2. A apropriação desse território tem sido realizada, desde o período colonial, de forma comprometedora para a biodiversidade e a economia do país" ${ }^{286}$

ÍCARO CUNHA ${ }^{287}$ também chama a atenção para o problema, salientando o despreparo dos municípios para enfrentar as complexas transformações territoriais determinadas pelo exercício de atividades de alto risco ambiental: "As áreas portuárias da costa de São Paulo (Santos e São Sebastião) têm nas operações de petróleo e gás uma atividade importante na constituição de uma rede técnica que as integre entre si e com outros parques produtivos do Estado e das regiões Sudeste/Centro-Oeste, por meio de dutovias. Tais operações estão em fase de expansão, com novos aproveitamentos dos recursos da Bacia de Santos, por meio de estruturas que passam pelo licenciamento ambiental para conexões na Baixada Santista e no Litoral Norte, e da infraestrutura existente, além do desenvolvimento de novas, complementares. Desenham-se novos desafios para a gestão ambiental desse processo, que se agregam aos já existentes, caracterizados pela evolução gerencial das empresas do sistema Petrobras, de um lado, e das agências governamentais, de outro. É um cenário em que interagem órgãos federais, estaduais e prefeituras, estas últimas, via de regra, mais despreparadas para governar as transformações territoriais complexas determinadas por atividades de risco ambiental. Completa-se este quadro com grupos das comunidades afetadas 
de alguma forma por tais intervenções, um público que emerge como ator relevante diante da tendência a reconhecer a importância de esquemas participativos de gestão".

A questão apresenta contornos ainda mais dramáticos, porquanto decorrente da exploração extrativista, cujas características demandam atenta análise, podendo resultar em maldição ou dádiva. ${ }^{288}$

É que a mineração ${ }^{289}$ é insustentável e locacional, já que os minerais são recursos inevitavelmente exauríveis. Todavia, pode ser um vetor de desenvolvimento econômico, desde que observadas duas condições: a primeira é promover investimentos que gerem riqueza alternativa, para substituir o patrimônio mineral consumido; a segunda é a minimização dos danos ambientais provocados pela atividade de mineração e de beneficiamento.

GILBERTO BERCOVICI observa que a indústria mineral sempre se organizou por meio de decisões tomadas fora dos países produtores ${ }^{290}$, que além da dependência de um único recurso exaurível, dependem ainda de uma atividade extrativista voltada para exportação, que exige grandes investimentos e que permanece, na maioria dos casos, como um enclave mais integrado à economia internacional do que à do próprio país produtor.

288 Conferir obra de Maria Amélia Enriquez, Mineração: maldição ou dádiva. Os dilemas do desenvolvimento sustentável a partir de uma base mineira, São Paulo, Signus, 2008, p. 95.

289 Importante ressaltar que petróleo não é mineral, mas hidrocarboneto.

290 Direito econômico do petróleo e dos recursos minerais, São Paulo, Quartier Latin, 2010, p. 40. 
Essa natureza de enclave decorre da baixa proporção da remuneração do trabalho e do capital no valor de mercado, o que concentra os lucros na esfera de troca, e não na esfera da extração. Resulta também da falta de vantagens locacionais que alimentem a mútua proximidade das empresas produtivas e da rigidez locacional dos recursos naturais que eleva custos de recrutamento de pessoal, de subsistência, de infraestrutura e de desenvolvimento, entre outros $^{291}$

É que um polo de extração não se torna, necessariamente, um polo de desenvolvimento, pois a lógica do enclave ${ }^{292}$ não gera nem os encadeamentos anteriores (abastecimento de insumos das atividades não primárias), nem os encadeamentos posteriores (como insumo em atividades novas) necessários para que ocorra efetivo desenvolvimento.

Isso não impede que, eventualmente, a rigidez locacional não possa ser solução para o início do processo de desenvolvimento de regiões remotas, desde que bem geridos os encadeamentos fiscais e viabilizada conexão produtiva e de consumo.

Há, por assim dizer, evidente desequilíbrio entre os níveis nacional e local da partilha dos custos e dos benefícios gerados pela atividade, cujos impactos são distribuídos de forma desigual entre os diferentes stakeholders, cabendo ao local o ônus (reestruturação social, cultural, política e ecológica) e ao país como um todo o bônus (divisas, rendas de tributos, desenvolvimento tecnológico).

291 Enriquez, cit. p. 95

292 Bercovici, cit., p. 40. 
Fato é que as expectativas eufóricas com a atividade mineradora não resistem ao tempo, pois as elevadas receitas públicas provenientes da fase do boom, bem como das rendas dos salários e dos impostos que são temporários e restritos à duração da atividade, declinam no colapso (bust) e tornam-se insuficientes para custear as despesas previamente assumidas e outros investimentos de longo prazo, além da dificuldade de realocação da mão de obra especializada. $^{293}$

O mesmo se dá com os benefícios que sobrevivem ao esgotamento da jazida, tais como infraestrutura de portos, estradas, parques, indústrias, escolas, caso não ocorra o encadeamento a partir de investimentos públicos e privados em diversificação industrial, independentemente da mineração.

Assim, os conceitos de sustentabilidade ${ }^{294}$ fraca ou sensata podem ser usados a partir de duas perspectivas: a da atual geração (intrageracional), que pressupõe a minimização dos danos ambientais e o aumento do bem estar social; e a da geração futura (intergeração), pela qual a atividade deve ser capaz de gerar um fluxo permanente de rendimentos para garantir o nível de bem estar.

É o escólio de JOSÉ ROBERTO RODRIGUES AFONSO e SÉRGIO WULFF GOBETTI, com esteio no conceito de Justiça intergeracional, para quem "o ideal é que as decisões de

293 Idem, p. 102-103.

294 Cf. supra 1.2.1. 
políticas públicas em torno da matéria tenham por objetivo básico proporcionar às gerações futuras uma compensação pela exploração presente de um recurso exaurível, o que pode ser feito sob diversas formas de poupança e investimento". ${ }^{295}$

Os autores sugerem ainda que a alocação de recursos deveria seguir a lógica de um Fundo Soberano, a exemplo de experiências de alguns países árabes, da Noruega ou mesmo de Estados como o Alaska e a província canadense Alberta, ou ainda do Fundo de Amparo ao Trabalhador (FAT), para formação de poupança e sua aplicação, especialmente em investimentos em infraestrutura econômica e social. ${ }^{296}$

Não obstante a pertinência da proposta e sua viabilidade nos casos de países como o Brasil, que apresentam enorme déficit social (saúde, educação, saneamento), bem como expressiva carência na área de infraestrutura (transportes, energia, comunicações) é questionada. A formação de poupança nesse contexto se afigura pouco crível. ${ }^{297}$

Outra providência, esta a cargo do poder público municipal na defesa do interesse local, diz respeito à utilização da CFEM - Compensação Financeira pela Exploração de Recursos Minerais, pois o uso das rendas hauridas da mineração é o elemento crítico que pode fazer a diferença entre uma mineração que se converte em dádivas ou, ao contrário, que produz maldição.

295 Rendas do petróleo no Brasil: Alguns aspectos fiscais e federativos. Revista do BNDES, № 30, RJ, dez/2008, p. 233.

296 Sobre a criação e gerenciamento de fundos, ver Bercovici, cit., p. 264.

297 Cit., p. 346. 
A CFEM $^{298}$ é calculada sobre o valor do faturamento líquido, obtido por ocasião da venda do produto mineral, consistindo vigoroso instrumento destinado a promover o desenvolvimento sustentável das regiões mineradoras, possibilitando seja compensado o impacto socioambiental da atividade, bem como propiciando atividades que substituirão a mineração após o esgotamento das jazidas. ${ }^{299}$

298 A Lei no 7.990, de 28.12.1989, instituiu para os Estados, Distrito Federal e Municípios, compensação financeira pelo resultado da exploração de petróleo ou gás natural, de recursos hídricos para fins de geração de energia elétrica, de recursos minerais em seus respectivos territórios, plataforma continental, mar territorial ou zona econômica exclusiva. A base de cálculo é definida pela Lei $n^{\circ} 8.001 / 90$, cujo art. $2^{\circ}$, $§ 1^{\circ}$, estabelece alíquotas distintas para diferentes minérios: I - alumínio, manganês, sal-gema e potássio: $3 \%$; II - ferro, fertilizante, carvão e demais substâncias minerais: $2 \%$; III - pedras preciosas, pedras coradas lapidáveis, carbonados e metais nobres: 0,2\%; IV - ouro: $1 \%$, quando extraído por empresas mineradoras, isentos os garimpeiros. No caso de petróleo e gás, as alíquotas eram reguladas pela Lei $\mathrm{n}^{\mathrm{a}}$ 9.478, de 06.08.1997, art. 47.

A Lei $n^{\circ} 9.478$, de 06.08.1997, dispõe sobre a política energética nacional, as atividades relativas ao monopólio do petróleo, institui o Conselho Nacional de Política Energética e a Agência Nacional do Petróleo (art. 45/52); a Lei oㅜ 12.351, de 22.12.2010, dispõe sobre a exploração e a produção de petróleo, de gás natural e de outros hidrocarbonetos fluídos, sob o regime de partilha de produção, em áreas do pré-sal e em áreas estratégicas, cria o Fundo Social - FS e dispõe sobre sua estrutura e fontes de recursos (art. 42 e 44); a Lei o 12.734, de 30.11.2012, modifica as Leis $n^{\circ}$ s 9.478 , de 06.08.1997 e 12.351, de 22.12.2010, para determinar novas regras de distribuição entre os entes da Federação dos royalties da participação especial devidos em função da exploração de petróleo, gás natural e outros hidrocarbonetos fluídos e, para aprimorar o marco regulatório sobre a exploração desses recursos no regime de partilha; a Lei no 12.858, de 09.09.2013, dispõe sobre a destinação para as áreas da educação e saúde, de parcela da participação no resultado ou da compensação financeira pela exploração de petróleo e gás natural, a partir de 03.12.2012, com a finalidade de cumprimento da meta prevista no inc. VI do art. 214 e no art. 196 da Constituição Federal, na percentagem de $75 \%$ para a educação e $25 \%$ para a saúde, em acréscimo ao mínimo obrigatório previsto na mesma Carta.

299 A natureza do presente trabalho justifica a abordagem apenas da CFEM pela sua relevância, enquanto instrumento manejado pelo Município na defesa do interesse local, não se olvidando das demais rendas, especialmente aquelas auferidas pela exploração do petróleo e gás: a) pagamento de bônus de assinatura - definido no edital de licitação dos blocos, pagos pela concessionária no momento da assinatura do contrato, corresponde à habilitação para o início dos serviços de exploração, com vistas a ressarcir o Estado pelos custos suportados pela administração com o controle e fiscalização dos atos praticados em razão da concessão ou da autorização; b) participações especiais - campos de grande volume de produção ou de expressiva rentabilidade; c) royalties pagos mensalmente, cuja acalorada discussão entre os estados produtores e os demais povoam o noticiário; d) pagamento pela ocupação ou pela retenção da área explorada - fixado em razão da área correspondente à superfície a ser explorada pela concessionária, variando conforme o tempo de duração do trabalho, as características geológicas e localização da bacia, pagos em percentual que incide na proporção dos lucros obtidos pelas empresas. 
A base de cálculo da CFEM é formada pelo preço do produto mineral, abatidos os custos para sua transformação de recurso em produto. E não se trata de abater todos os custos, mas apenas aqueles que se referem a transporte, seguro e tributos, até a última etapa do beneficiamento adotado e antes de sua transformação industrial, independente de terem ou não sido destacados na nota fiscal. ${ }^{300}$

Embora não haja vinculação, o Departamento Nacional de Produção Mineral recomenda a aplicação dos recursos provenientes da CFEM em projetos que direta ou indiretamente revertam em prol da comunidade local, na forma de melhoria da infraestrutura, da qualidade ambiental, da saúde e educação. Por determinação legal ${ }^{301}$, os recursos não podem ser gastos ou utilizados para o pagamento de dívidas e nem para a contratação de pessoal permanente.

Ao comparar os efeitos da utilização da CFEM em municípios mineradores localizados em regiões distintas, noticia experiências como MARIA AMÉLIA ENRIQUEZ bem alerta à chamada armadilha do caixa único ${ }^{302}$ : "A maioria dos municípios usa a CFEM como um

300 Fernando Facury Scaff, Aspectos controvertidos sobre a CFEM - Compensação Financeira pela Exploração de Recursos Minerais, p. 309, in. Direito Tributário e Econômico aplicado ao Meio Ambiente e à Mineração, São Paulo, Quartier Latin, 2009.

301 Lei no 7.990/89, regulamentada pelo Decreto no $1 / 91$.

302 A autora noticia a diversidade de experiências na utilização da mencionada compensação, o que realça a importância do Município no processo de desenvolvimento sustentável na promoção do interesse local: "As rendas oriundas da produção de bens minerais representam parte substancial das receitas públicas de muitos municípios brasileiros. Além desse aspecto quantitativo, é no aspecto qualitativo que a receita da CFEM tem o seu caráter estratégico, pois não é vinculado a gastos previamente definidos, o que possibilita ampla flexibilidade de seu uso. Esta característica gera um conjunto de preocupações de caráter econômico-financeiro, social e distributivo". Armadilha do caixa único - os recursos entram no caixa da prefeitura e se 'diluem' nas despesas correntes. Nesse padrão, lamentavelmente, se enquadram dois terços do universo pesquisado - Vitória do Jari (AP), Jaguarari (BA), Crixás (GO), Mariana (MG), Santa Bárbara (MG), Corumbá (MS), Canaã dos Carajás (PA), Ipixuna do Pará (PA), Oriximiná (PA) e Parauapebas (PA). Uso sustentado - os recursos da CFEM entram no caixa da prefeitura e são direcionados (total ou parcialmente) para determinados fins previamente definidos. Nesse padrão, encontra-se um terço do universo pesquisado - Itabira (MG), Minaçu (GO), Forquilhina (SC) e, parcialmente, Paracatu (MG), Rosário do Catete (SE). 
recurso orçamentário qualquer, procedimento que foi denominado de armadilha do caixa único. Com os valores assim diluídos, o gestor não percebe as potencialidades transformadoras da CFEM. Essas potencialidades têm se realizado em alguns municípios que a usam como instrumento para diversificar a atividade produtiva, promover a inclusão social e elevar o nível de capacitação científica e tecnológica de seus recursos humanos e empresas, embora ainda haja uma grande distância entre isso e uma efetiva promoção de um desenvolvimento local sustentável. ${ }^{303}$

Há, portanto, um descontentamento generalizado quanto à efetiva contribuição da CFEM para a promoção do desenvolvimento local. As companhias mineradoras alegam não perceber o uso produtivo desse instrumento. Afirmam que a lei é falha, pois não vinculou o benefício a qualquer uso fecundo. Os governos locais, por sua vez, reclamam que os valores recebidos são insuficientes para custear o atendimento das demandas sociais, que crescem significativamente com o advento da atividade mineradora. Embora a lei não permita, muitos gestores públicos usam os valores da CFEM para custear a folha de pagamento dos servidores municipais. Os demais representantes da sociedade civil também afirmam desconhecer a origem e as formas de uso da CFEM". 304

FERNANDO FACURY SCAFF observa que a CFEM não possui natureza jurídica tributária, caracterizando-se como uma compensação pela exploração de recursos minerais, com

303 Enriquez, p. 358

304 Cit. p. 357-358. 
natureza jurídica de direito econômico e financeiro ${ }^{305}$. É receita originaria da União pela utilização de bem de uso especial, a teor dos art. 20, IX, e 176 da Constituição Federal.

Os valores arrecadados pela União a título de CFEM são partilhados com Estados e Municípios, na forma da lei ${ }^{306}$, não caracterizando com isso uma receita própria desses entes subnacionais, mas receita transferida, 307na forma da Lei $n^{\circ} 4.320 / 64$, que estatui normas gerais de direito financeiro para elaboração e controle dos orçamentos e balanços da União, Estados, Municípios e Distrito Federal. Assim não é possível aos entes subnacionais arrecadar diretamente a CFEM - transformando-a em receita própria - pois se trata de uma receita a ser arrecadada pelo DNPM e transferida aos demais entes subnacionais.

Dessa forma, a adequada utilização das receitas advindas da exploração de petróleo e gás na Zona Costeira pode ser assegurada pela criação de fundos, vinculação das rendas provenientes da atividade (royalties e CFEM) ou, ao menos, pela imposição de maiores restrições à sua utilização perdulária pelos Municípios.

305 Aspectos controvertidos..., p. 310

306 Lei ํㅜ 8.001, de 13.03.1990, art. ㄴo, § 2º: I - 23\% para os Estados e o Distrito Federal; II - 65\% para os Municípios. A parcela de $12 \%$ da Administração Direta da União foi retalhada pela Lei ํo 9.993/00, entre: a) $2 \%$ para o Fundo Nacional de Desenvolvimento Científico e Tecnológico - FNDCT; b) $10 \%$ para o Ministério de Minas e Energia a ser repassado diretamente ao Departamento Nacional de Produção Mineral (DNPM), que destina $2 \%$ desta cota parte à proteção mineral em regiões mineradoras, por intermédio do Instituto Brasileiro de Meio Ambiente e dos Recursos Naturais Renováveis - IBAMA. O Decreto oㅡ 1, de 11.01.1991 regulamentou as Leis ํo 7.990, de 28.12.1989 e 8.001, de 13.03.1990.

307 Mesmo sendo receita transferida, existe a possibilidade dos entes subnacionais fiscalizarem a arrecadação efetuada pelas empresas mineradoras atinentes à CFEM, desde que seja firmado um Convênio com o DNPM, pois este é o órgão legalmente encarregado da arrecadação e da fiscalização dessa exação. 


\subsection{Sistema portuário}

Resultado do aquecimento da atividade econômica do país, aliado ao incremento da indústria do turismo e da atividade de exploração de petróleo e gás, o sistema portuário brasileiro constitui um dos gargalos que entravam o desenvolvimento do país, desempenhando o Município papel de relevo no seu redimensionamento.

Não existem países com zonas costeiras sem portos e, para esses, converge toda a atividade produtiva do país, contabilizando-se o sistema de transporte, energia, comunicações, enfim, a vida econômica do país.

Terminais portuários apresentam especial potencial de risco ambiental, seja pelo transporte de carga via embarcações ou dutos, seja pelos processos de carregamento e descarregamento do produto.

Apresentam ademais risco de acidentes que podem causar danos de expressiva extensão (explosões e incêndios), agravados se localizados no perímetro urbano, como boa parte dos portos brasileiros. Acresça-se a isso, a deterioração do entorno urbano causada pela desativação dos terminais de passageiros ocorrida com o desenvolvimento do transporte aéreo. 
Nesta quadra, não há como afastar o interesse local $^{308}$ no exercício e fiscalização de tais atividades, pois com o seu desenvolvimento não apenas o bônus econômico e social, mas, principalmente ônus, exigem a participação da comunidade local. ${ }^{309}$

$\mathrm{O}$ art. 21, XII, $f$, da Constituição Federal $^{310}$ atribui à União a competência para explorar, diretamente ou mediante autorização, concessão ou permissão, os portos marítimos, fluviais ou lacustres.

A Lei $n^{\circ}$ 8.630, de 25.02.1993 (Lei dos Portos) tratou do arrendamento e da autorização, hipóteses de exploração sujeitas a regime jurídico de direito público, revogada pela Lei $\mathrm{n}^{\circ}$ 12.815, de 05.06.2013.

A Lei $n^{\circ}$ 10.233, de 05.06.2001 disciplinou a concessão e autorização, considerando a exploração do porto organizado como serviço público, e a exploração dos terminais situados fora do porto organizado como atividade a ser exercida em regime de liberdade de preços, tarifas e fretes e em ambiente de livre e aberta competição (art. 43, II), observado o regime de direito público a que alude a Lei $\mathrm{n}^{\circ}$ 8.630, de 25.02.1993 (art. 33 da Lei $\mathrm{n}^{\circ}$ 10.233, de 05.06.2001). Dispôs também sobre a reestruturação dos transportes aquaviários e terrestres, criou o Conselho Nacional de Integração de Políticas de Transporte, a Agência Nacional de

308 Cf. supra 2.2.

309 ADI - Lei que estabelece 'Zonas Portuárias' - Violação ao meio ambienta não caracterizada Ação improcedente. Não viola os art. 16,140,141 e 181 da Constituição do Estado de Santa Catarina lei municipal que apenas estabelece 'zonas portuárias', visando 'estimular, concentrar e agrupar as atividades comerciais, industriais e de serviços, principalmente voltadas a função portuária' (Lei $n^{\circ} 587$, de 2007, do Município de São Francisco do Sul). A lei não desobriga o interessado na ocupação de área situada no perímetro de zonas portuárias de cumprir a legislação nacional e estadual; a ocupação somente será lícita se previamente licenciada pelos órgãos oficiais de proteção ambiental (Ibama, Fatma, etc). Os desvios na aplicação da lei poderão ser coibidos via ação civil pública, assegurando-se o direito ao contraditório e à ampla defesa (TJSC ADI 2008.009253-3, Órgão Especial, Rel. Des. Newton Trisotto, j. 31.08.2010).

310 Art. 21. Compete è União: (...) XII, Explorar, diretamente ou mediante autorização, concessão ou permissão: (...) f) os portos marítimos, fluviais e lacustres. 
Transportes Terrestres, a Agência Nacional de Transportes Aquaviários e o Departamento Nacional de Infra Estrutura de Transporte. ${ }^{311}$

\section{FLORIANO DE AZEVEDO MARQUES NETO e FÁBIO BARBALHO LEITE ${ }^{312}$,} ressaltam a incidência do regime jurídico de direito público, seja qual for o aspecto que se considere: "É de se concluir que o regime aplicável aos contratos de arrendamento previstos na Lei $\mathrm{n}^{\circ}$ 8.630/93 será, necessariamente o regime de direito público, seja pelo fato de que a exploração dos portos constitui serviço público, seja porque as instalações portuárias tem natureza de bens públicos de uso especial, seja ainda porque existe evidente interesse público envolvido. Ainda que persista a controvérsia quanto à verdadeira natureza do contrato concessão de serviço público ou concessão de uso de bem público - não poderá haver dúvida quanto ao regime que lhe é aplicável: trata-se, indiscutivelmente, de regime de direito público. E as contratações em causa, por uma ou outra opção (concessão de serviço ou de uso do bem), sempre serão contratos administrativos".

311 Maria Sylvia Zanella Di Pietro demonstra as inovações então trazidas pela Lei $n=10.233$, de 05.06.2001: "a) passou a falar em concessão e não mais em arrendamento, como instrumento de outorga na área do porto organizado (art. 13 e 14), embora admitindo que a concessão possa estar vinculada a um contrato de arrendamento de ativos e a contratos de construção com cláusula de reversão ao patrimônio da União (art. 14, § $3^{\circ}$ ); isso significa que fez a distinção que não constava na lei anterior, entre arrendamento (cujo objeto é a transferência do uso e gozo de área pública dentro do porto organizado) e concessão (cujo objeto é a exploração de área dentro do porto organizado, com prestação de serviço público a terceiros); b) não mais previu o contrato de adesão como instrumento de formalização da autorização; segundo o art. 13, II, c, depende de autorização a construção e operação de terminais de uso privativo, conforme disposto na Lei no 8.630, de 25.02.1993; como se verifica, manteve o conceito e as normas da Lei dos Portos sobre uso privativo; c) exigiu licitação para as outorgas de concessão, fazendo remissão ao art. 175 da CF (art. 13, § 10, e art. 34-A, e dispensou a licitação para as autorizações (art. 43, I); d) criou a Agência Nacional de Transportes Aquaviários (ANTAQ) como agência reguladora dos portos organizados e dos terminais portuários de uso privativo (art. 23, II e III) e a ela atribuiu a competência para autorizar a construção e a exploração de terminais portuários de uso privativo, conforme previsto na Lei no 6.830/1993 (art. 27, XXII); a referência à Lei de Portos está a indicar que as modalidades de uso nela previstas não foram alteradas, continuando a existir os usos públicos e os usos privativos, nas três espécies previstas no art. $4^{\circ} \stackrel{\text {, }}{\S} 2^{\circ}$, já analisados; e) deixou expresso que a autorização não está sujeira a prazo de vigência, extinguindo-se pela sua plena eficácia, por renúncia, anulação ou cassação (art. 43, III), ao contrário da Lei no 8.630, que, no art. 4ㅇ, XI, fixava o prazo máximo de cinquenta anos, incluindo a prorrogação; esse prazo era aplicado às autorizações conforme decorria do art. $6^{\circ}, \S 1^{\circ}$ " (Uso privativo de bem público por particular, p. 140141).

312 Peculiaridades do contrato de arrendamento portuário, Revista de Direito Administrativo, vol. 231, jan./mar. 2003, p. 283, consignando a natureza de contrato complexo, pois contempla tanto a concessão de um serviço público quanto a concessão de um bem público. 
VITOR RHEIN SCHIRATO ${ }^{313}$ _lembra que a delegação por meio de convênio para exploração de porto organizado por meio de empresa estatal controlada por ente da federação, anteriormente à edição da Lei $\mathrm{n}^{\circ} 11.107$, de 06.04.2005, se dava por meio de simples convênio administrativo entre os entes federativos em questão, exigindo-se agora: (i) a formação de um consórcio público entre a União Federal, na qualidade de titular dos serviços portuários, e o ente da federação que se incumbirá da prestação dos serviços; (ii) a ratificação, pelos respectivos poderes legislativos, dos termos e condições do consórcio; e (iii) a celebração de um contrato de programa que disciplinará a prestação dos serviços pela empresa estatal controlada pelo respectivo ente federativo, no âmbito do consórcio público formado.

Resta saber se, no que diz respeito ao âmbito específico deste trabalho, por ente federativo se entende o Município. ${ }^{314}$

Impende salientar que a regulação do setor é feita pela ANTAQ - Agência Nacional de Transportes Aquaviários, autarquia integrante da Administração Indireta da União, criada pela Lei $n^{\circ} 10.233 / 2001$, cuja competência é detalhada por VITOR RHEIN SCHIRATO ${ }^{315}$ : "Essencialmente compete à ANTAQ a execução das diretrizes e políticas públicas das atividades de navegação e transportes aquaviários de passageiros e cargas e das atividades de exploração e desenvolvimento de infraestruturas portuárias, estabelecidas, respectivamente, pelo Ministério dos Transportes e pela Secretaria Especial de Portos. Na execução de tais diretrizes e políticas públicas está incluída tanto a realização de todos os atos materiais para a

313 Transportes aquáticos. Doutrina, jurisprudência, legislação e regulação setorial, São Paulo, Saraiva, 2012, p 31-32. Conferir também p 30-40, sobre terminais portuários públicos (porto organizado/arrendamento portuário) e privativos, estações de transbordo de cargas e instalações portuárias de pequeno porte.

314 Cf. supra 2.1.

315 Transportes aquaviários, p. 24-25. 
outorga de concessões, permissões e autorizações quanto à fiscalização da atuação de todos os agentes econômicos dos setores de navegação e portos. Nessa senda, incumbe à agência, nos termos do art. 27 da Lei $n^{\circ} 10.233 / 2001$, entre outras atividades: i) elaborar e submeter à aprovação da Secretaria Especial de Portos o PGO de infraestruturas portuárias; ii) elaborar editais e contratos de concessão de serviços portuários; iii) outorgar e celebrar contratos de concessão, em nome da União Federal, por delegação da Secretaria Especial de Portos, com relação à concessão de serviços públicos portuários; iv) outorgar autorizações para a exploração de atividades de navegação, tanto com relação ao transporte de passageiros quanto ao transporte de cargas; v) fiscalizar diretamente as atividades das concessionárias e prestadoras de serviços portuários; vi) fiscalizar, conjuntamente com as autoridades portuárias, as atividades das empresas arrendatárias de instalações portuárias; vii) outorgar autorizações para a construção e a exploração de instalações portuárias de interesse privativo; e viii) fiscalizar as empresas de navegação (...) Demais disso, é relevante mencionar que à ANTAQ compete promover e defender interesses dos usuários dos serviços portuários e dos serviços de navegação, devendo, a todo tempo, controlar e fiscalizar a atuação das empresas de navegação e das controladoras e detentoras de infraestruturas portuárias para assegurar o constante respeito aos direitos básicos dos usuários”.

A Lei $n^{\circ} 12.815$, de 05.06.2013, revogou a Lei $n^{\circ} 8.630$, de 25.02.1993, e regulou a exploração pela União, direta ou indiretamente, dos portos e instalações portuárias e as atividades desempenhadas pelos operadores portuários.

$\mathrm{O} \S 1^{\circ}$ do art. $1^{\circ}$ da lei prevê que a exploração indireta do porto organizado e das instalações portuárias nele localizadas ocorrerá mediante concessão e arrendamento de bem público (art. 
$4^{\circ}$ a $7^{\circ}$ ), enquanto o $\S 2^{\circ}$ sujeita à autorização a exploração indireta das instalações portuárias

localizadas fora da área do porto organizado (art. $8^{\circ}$ a 13 ).

Em ambos os casos, as concessões, os arrendamentos e as autorizações serão outorgados a

pessoa jurídica que demonstre capacidade para seu desempenho, por sua conta e risco.

$\mathrm{O}$ art. $2^{\circ}$ da mencionada lei contém a nomenclatura adotada pela Lei. ${ }^{316}$

As diretrizes da nova lei encontram-se postas no art. $3^{\circ}$, entre as quais se destacam a

expansão, modernização e otimização de sua infraestrutura; garantia de modicidade das tarifas

316 Art. $2^{\circ}$ Para os fins desta Lei, consideram-se: I - porto organizado: bem público construído e aparelhado para atender a necessidades de navegação, de movimentação de passageiros ou de movimentação e armazenagem de mercadorias, e cujo tráfego e operações portuárias estejam sob jurisdição de autoridade portuária; II - área do porto organizado: área delimitada por ato do Poder Executivo que compreende as instalações portuárias e a infraestrutura de proteção e de acesso ao porto organizado; III - instalação portuária: instalação localizada dentro ou fora da área do porto organizado e utilizada em movimentação de passageiros, em movimentação ou armazenagem de mercadorias, destinadas ou provenientes de transporte aquaviário; IV - terminal de uso privado: instalação portuária explorada mediante autorização e localizada fora da área do porto organizado; $V$ estação de transbordo de cargas: instalação portuária explorada mediante autorização, localizada fora da área do porto organizado e utilizada exclusivamente para operação de transbordo de mercadorias em embarcações de navegação interior ou cabotagem; VI - instalação portuária pública de pequeno porte: instalação portuária explorada mediante autorização, localizada fora do porto organizado e utilizada em movimentação de passageiros ou mercadorias em embarcações de navegação interior; VII - instalação portuária de turismo: instalação portuária explorada mediante arrendamento ou autorização e utilizada em embarque, desembarque e trânsito de passageiros, tripulantes e bagagens, e de insumos para o provimento e abastecimento de embarcações de turismo; VIII - (VETADO); IX concessão: cessão onerosa do porto organizado, com vistas à administração e à exploração de sua infraestrutura por prazo determinado; $X$ - delegação: transferência, mediante convênio, da administração e da exploração do porto organizado para Municípios ou Estados, ou a consórcio público, nos termos da Lei no 9.277, de 10 de maio de 1996; XI - arrendamento: cessão onerosa de área e infraestrutura públicas localizadas dentro do porto organizado, para exploração por prazo determinado; XII - autorização: outorga de direito à exploração de instalação portuária localizada fora da área do porto organizado e formalizada mediante contrato de adesão; e XIII - operador portuário: pessoa jurídica pré-qualificada para exercer as atividades de movimentação de passageiros ou movimentação e armazenagem de mercadorias, destinadas ou provenientes de transporte aquaviário, dentro da área do porto organizado. 
e preços e qualidade do serviço; aprimoramento da gestão e qualificação de mão de obra; promoção da segurança da navegação; e estímulo à concorrência.

Não obstante o fato de portos e aeroportos serem instalações que representem, por excelência, contato com o mundo externo, não se pode deixar de reconhecer a relevância do Município na sistemática adotada pela nova lei, porquanto o art. 14, ao dispor sobre os requisitos para implantação de portos e instalações portuárias, estabelece que "A celebração do contrato de concessão ou arrendamento e a expedição de autorização são precedidos de: (...) II consulta ao respectivo poder público municipal”.

Ademais, o art. 16 da mesma lei, ao aludir à competência do poder concedente da União, prevê a celebração de convênios e instrumentos congêneres de cooperação técnica e administrativa com órgãos e entidades da Administração Pública Federal, dos Estados, do Distrito Federal e dos Municípios, inclusive com repasse de recursos.

Exemplo da importância da atividade portuária na vida econômica e social do Município está na inserção do maior porto da América Latina na dinâmica do município de Santos ${ }^{317}$, que passa pela solução de entraves e problemas de toda ordem: ambiental, viário ${ }^{318}$,

317 "A expatriação do território físico da cidade de Santos é fator que colabora para a manutenção do status quo, no que se refere ao território federal dentro do espaço local. A partir da concessão por 90 anos do Porto de Santos, em 1890, a faixa portuária tornou-se fisicamente separada da cidade, constituindo-se território pertencente ao Governo Federal, autônomo e não sujeito às leis municipais. A ordenação das áreas da cidade, por parte das leis municipais de uso e ocupação do solo, viabilizou também a expansão portuária, definindo zonas urbanas como retroportuárias e industriais para atender aos interesses do processo produtivo" (Maria Cristina Lino Cândido, Portos e ambientes costeiros: disputas e conflitos do recurso estuário e suas consequências no espaço local, in Ícaro Cunha e Maria Fernanda Brito Neves, Gestão ambiental na costa, portos e sustentabilidade, Santos, Leopoldianum, 2009, p. 120, p. 113-128).

318 Os municípios da Região Metropolitana da Baixada Santista, instituída pela LC no 815, de 30.07.1996, conectam-se com as áreas de influência primária do Porto de Santos a partir de vias de acesos rodoviários, ferroviários e dutoviários existentes. O modal rodoviário é responsável por aproximadamente $73 \%$ da carga movimentada, o ferroviário por aproximadamente $20 \%$ e o dutoviário 
socioeconômico, entre outros, cujo êxito não se dará sem a efetiva participação dos agentes públicos e privados locais. Neste caso específico, por certo que o interesse local se mescla ao nacional.

ALEXANDRE SOFIA GROTA ${ }^{319}$ indica os instrumentos de planificação que ordenam o uso do solo no estuário da região: “Os principais instrumentos de planificação que ordenam o uso do solo no estuário são os planos diretores municipais e o Zoneamento Ecológico Econômico (ZEE) da Baixada Santista. O Plano Diretor de Santos está vigente desde 1998, com a homologação da LC no 311. O de Guarujá Também entrou em vigor em 1998, com a aprovação da LC $n^{\circ}$ 43/98. O Plano Diretor da cidade inseriu a integralidade do Porto Organizado em zona portuária, enquanto que no de Santos existe uma área dentro da zona portuária, correspondente ao denominado lixão da Alamoa, classificada como ZPP, ou seja, Zona de Preservação Paisagística, na qual as atividades portuárias estão proibidas”.

Não obstante a existência de normatização municipal a respeito ${ }^{320}$, a gestão do Porto, administrado pela Companhia Docas do Estado de São Paulo (CODESP), passa por

por aproximadamente 7\%. Além do vetor logístico Centro-Sudeste como área de influência primária do Porto de Santos, a área de influência secundária compreende todo o restante do Brasil e alcança também parte de outros países sul-americanos, como Paraguai e Uruguai e parte da Argentina, Bolívia e Chile. O sistema portuário ali instalado atende à área de influência primária compreendida pelos estados de SP, MG, MT, MS, GO, DF que, em conjunto, representa 75 milhões de pssoas, $67 \%$ do PIB brasileiro, $56 \%$ da balança comercial brasileira, em valores, $60 \%$ do comércio internacional do estado de São Paulo (Diagnóstico Urbano Socioambiental - Município de Cubatão - Bases das Informações até 2012 - Revisão Março de 2013 - Convênio Petrobrás Instituto Polis - Relatório nª 6, p. 10).

319 Discutindo o Plano de Gestão Ambiental do Porto de Santos, in Ícaro Cunha e Maria Fernanda Brito Neves (Org.) Gestão ambiental na costa, portos e sustentabilidade, p. 67-88.

320 A respeito das áreas de acesso restrito, como instalações portuárias, o poder de polícia da administração do porto não inclui a proibição ou restrição do acesso a essa área, da autoridade municipal ou de servidores municipais no exercício de sua função; pois, nesses casos, no que diz respeito ao acesso, cabe-lhe apenas exigir a identificação dessas pessoas. Também não inclui a proibição de execução de terminais marítimos para desembarque e distribuição de passageiros. Integra a autonomia do município o direito de executar esses serviços, projetar e realizar essas obras, mediante mera comunicação, ressalvada à autoridade federal o poder de embargá-las, 
limitações de toda ordem (isolamento dos usuários, falta de recursos humanos e materiais, ausência de planejamento, sistema viário precário, entre outras), pois a CODESP é apenas um dos usuários do estuário que até 2009 contava com 64 áreas arrendadas, devendo a atividade ser gerenciada por meio de parcerias com as empresas arrendatárias, operadores portuários, comunidades locais e prefeituras da região ${ }^{321}$.

O mesmo problema é apontado por MARIA CRISTINA LINO CÂNDIDO 322: “A premissa de transformar o porto de Santos em um hub port ${ }^{323}$ torna-se incompatível com o desenvolvimento territorializado devido à falta de permanência dos recursos financeiros na cidade e de participação e envolvimento da comunidade como um todo. (...) Embora se tenha verificado alguns esforços na compatibilização de políticas urbanas e portuárias na Cidade de Santos, a desordem portuária ainda acontece diante da ausência de políticas conjuntas e sustentáveis no âmbito local/regional e nas demais esferas a que o porto hoje está submetido. As relações cidade e porto, com políticas diferenciadas, afetam todos os segmentos envolvidos nas atividades portuárias e nas demais atividades desenvolvidas pelas populações locais",

justificadamente, caso interfiram danosamente nas atividades sob sua supervisão; em qualquer hipótese. Entretanto não poderá existir vedação absoluta - sem margem a alternativas - à atuação do poder público municipal (Sérgio Sérvulo da Cunha, cit. p. 269-273).

321 Discutindo o plano de gestão ambiental do Porto de Santos, Alexandre Sofia Grota, p. 69-88. Conferir também Maria Fernanda Brito Neves, A expansão territorial do Porto de Santos: caminhos e desafios para a sustentabilidade, p. 129-148, In Ícaro Cunha e Maria Fernanda Brito Neves, Gestão ambiental na costa, portos e sustentabilidade.

322 Portos e ambientes costeiros: disputas e conflitos do recurso estuário e suas consequências no espaço local, in Ícaro Cunha e Maria Fernanda Brito Neves, cit., p. 113-128.

$323 \mathrm{O}$ Hub port funciona como elo logístico independente do território que ocupa e suas operações tem alcance fora do porto e de seu local de implantação; exige infraestrutura grandiosa, dependente de grandes empresas e armadores globais; dificilmente incluem pequenas e médias empresas em seu formato empresarial. Outro modelo é a cidade portuária, funciona como instrumento de desenvolvimento local, insere sua hinterlândia mais próxima em seu planejamento territorial; o porto encontra nas esferas sociais urbanas os recursos empresariais e as competências para aprimorar seus serviços, gerando valor e empregos. 
Conclui a autora: "Verifica-se, portanto, a interferência dos micro e macroambientes que fizeram da cidade uma área fragmentada, onde os diversos agentes do porto e da comunidade convivem em situação de exclusão mútua, causando a degradação de áreas e a falta de conexão entre o sistema produtivo e o mercado de trabalho, com os diversos interesses agindo isoladamente. Podemos comparar essa situação de exploração do território àquela colonial, onde o espaço urbano serve de suporte para a infraestrutura, fornece a mão de obra (atualmente mínima) e suporta os transtornos causados pela movimentação e armazenamento das cargas no espaço físico e a degradação do meio ambiente, sem colaborar com o retorno social".

ÍCARO ARONOVICH DA CUNHA e LUCIANO A. PRATES JUNQUEIRA ${ }^{324}$ salientam a importância do plano local na solução de impasses havidos entre o porto de São Sebastião, o maior terminal de petróleo da América Latina, e a comunidade, solução essa construída a partir do consenso de se reconhecer o dinamismo econômico da atividade do terminal como imprescindível ao município, e que resultou no desenvolvimento do bem sucedido Plano Apell: “Até o ano 2000, a instalação e suas operações de transporte e armazenamento de produtos registraram 220 acidentes, em sua grande maioria derramamentos de petróleo no mar. No final dos anos 80, havia em São Sebastião um ambiente de acirrado conflito ambiental, provocado não apenas pelos acidentes com petróleo, mas também pelos impactos de um processo de urbanização desordenado promovido pela ocupação imobiliária que se seguiu ao asfaltamento da estrada Rio-Santos em 1984, bem como pelos projetos ligados à expansão do porto de cargas gerais, o Porto DERSA.

Com a volta das eleições diretas para prefeito em 1985, a política local começou a incorporar

324 Governança ambiental e gerenciamento social dos riscos, in Direito do petróleo e gás - aspectos ambientais e internacionais, Alcindo Gonçalves e Gilberto M. A. Rodrigues (Org.), p. 151-163. 
a questão ambiental como tema de destaque. Nos anos 89-92, a administração municipal desenvolveu uma política de meio ambiente, incluindo legislação que criava o licenciamento ambiental vinculado à participação da comunidade por meio do Conselho de Meio Ambiente, de composição paritária entre representantes do governo e entidades da sociedade civil.

O terminal da Petrobras foi obrigado a pedir autorização ambiental de funcionamento à Prefeitura a cada dois anos, devendo para tanto, apresentar ao município seus estudos de riscos. A análise e as exigências da Prefeitura poderiam apoiar-se nos estudos da Companhia de Tecnologia de Saneamento Ambiental (CETESB) e contar com pareceres técnicos adicionais, se necessário.

Em 1992, com o licenciamento municipal, pela primeira vez o risco de acidentes ambientais associados ao terminal foi analisado e debatido publicamente. Na sequência dessa primeira autorização ambiental, que continha cerca de 60 exigências de medidas de segurança, a Prefeitura propôs ao terminal o desenvolvimento do Plano Apell, com o objetivo desenvolver condições de segurança para a população que habita nas imediações do terminal.

O plano só seria efetivamente implantado na administração 1997-2000, consolidando um período de importante evolução na gestão dos riscos do terminal. Na segunda metade da década de 90, atendendo às exigências da CETESB e da Prefeitura, a Petrobras investiu em seu terminal de São Sebastião US\$ 36 milhões em medidas de segurança ambiental, reduzindo drasticamente o número de acidentes e - o que do ponto de vista do dano ambiental é muito importante - o volume de produtos derramados".

A Lei $n^{\circ}$ 11.518, de 05.09.2007 criou as estações de transbordo de cargas (Resolução ANTAQ 
$\mathrm{n}^{\mathrm{o}} 1.555 / 2009$ ) e as instalações portuárias de pequeno porte (Resolução ANTAQ no 1.590/2010), como instalações localizadas fora da área dos portos organizados, que não demandam operador portuário para sua operação e necessitam tão somente de simples autorização da ANTAQ para funcionar.

No caso específico das marinas ${ }^{325}$, a Lei $\mathrm{n}^{\mathrm{o}} 9.636$, de 15.05 .1998 , em seu art. 18 , § $2^{\mathrm{o} 326}$, previu a possibilidade de cessão de uso de áreas públicas para esse fim, até então precariamente disciplinado pelo Decreto-lei $\mathrm{n}^{\circ} 178$, de 16.02 .1967 , cujo art. $1^{\circ}$ permitia a cessão de terrenos da União aos Estados, Municípios, entidades educacionais, culturais ou filantrópicas sociais e a pessoas físicas ou jurídicas no caso de aproveitamento econômico e de interesse social.

O desenvolvimento da indústria do turismo proporcionou expressivo crescimento do número de embarcações de recreio e, consequentemente, a construção de piers, marinas e atracadouros e instalações de apoio como oficinas, docas, tanques de combustível, sistemas sanitários, além da dragagem de canais, etc. ${ }^{327}$

325 Ver Gilberto D'Avila Rufino, Regime legal das marinas no direito comparado, Revista de Direito Ambiental, vol. 24, out.-dez 2001, p. 103, o autor demonstra a necessidade de adaptar a legislação à dinâmica do setor, afastando os entraves para o seu desenvolvimento da indústria náutica e das atividades correlatas: "Diferentemente dos portos de comércio e militares, cuja localização obedece a outros critérios e estratégias, as estruturas náuticas estão condicionadas pelo alcance limitado das pequenas embarcações que, para segurança dos equipamentos e tripulações, impõe a realização de escalas distantes umas das outras, não mais do que vinte milhas náuticas. Outrossim, a navegação de recreio organiza-se em torno de atrativos naturais e de características geomorfológicas da costa que predeterminam a viabilidade e sucesso dos empreendimentos".

326 Art. 18, § 20 O espaço aéreo sobre bens públicos, o espaço físico em águas públicas, as áreas de álveo de lagos, rios e quaisquer correntes d'água, de vazantes da plataforma continental e de outros bens da União, insuscetíveis de transferência de direitos reais a terceiros, poderão se objeto de cessão de uso, nos termos deste artigo, observadas as prescrições legais vigentes.

327 Ver John Vernberg e Winona Vernbegr, cit. p. 112-113. 


\section{CONSIDERAÇÕES FINAIS}

a) Necessidade de tratamento unitário da zona costeira

Na zona costeira brasileira encontra-se grande parte da atividade econômica, significativas referências de nossa identidade nacional, bem como áreas de interesse turístico, de recreação e de lazer, atividades que proporcionaram uma segunda fase na sua ocupação, agora às voltas com as descobertas de expressivas jazidas de petróleo e gás, que por certo darão nova moldura à região.

Não obstante a sua inserção no art. 225 da Carta de 1988, como área de patrimônio nacional, até o momento, o Estado Brasileiro foi incapaz de promover o desenvolvimento sustentável da região costeira e de atender à demanda por serviços públicos básicos, gerando um quadro de carências estruturais e consequente exclusão social, refletidas na ocupação irregular de áreas, na favelização e no aumento da criminalidade.

O estabelecimento de faixas distintas formadas a partir do terreno de marinha, passando pela orla marítima, atingindo os municípios situados na área de influência ambiental ou econômica, constitui entrave jurídico ao seu adequado gerenciamento, cabendo à União apenas dispor sobre normas gerais de sua ocupação, restando ao Município a sua concreção. Assim, a consolidação do tratamento unitário da zona costeira na esfera municipal constitui providência imperativa. 


\section{b) Participação do Município no PNGC}

O Projeto ORLA foi criado para responder às demandas de ordenamento do uso e ocupação das bordas litorâneas, que se tornaram evidentes na prática da gestão ambiental e patrimonial, como reflexo da fragilidade dos ecossistemas, da falta de planejamento, do crescimento desordenado das cidades, do aumento dos processos erosivos e das fontes contaminantes de orla. No âmbito deste Projeto, as atribuições reservadas aos entes federativos superiores possuem natureza de supervisão e coordenação, ao passo que aos Municípios compete execução do projeto, com o levantamento da documentação necessária, elaboração do plano, entabulamento de convênios e definição da agenda.

A Agenda 21 destaca que a atuação da autoridade local, enquanto nível decisório de governo mais próximo do povo, portanto mais apto à obtenção de soluções consensuais e menos intrusivas, desempenha um papel essencial na educação, mobilização e resposta ao público, em favor de um desenvolvimento sustentável, pois a participação do cidadão munícipe nas decisões que afetam a comunidade ocorre com maior eficácia no nível decisório local do que no plano regional ou na distante esfera nacional.

Nesse sentido, um dos objetivos do Projeto Orla é precisamente acelerar a implantação de cessão patrimonial para os Municípios, especialmente para aqueles de pequeno porte, desprovidos de recursos e quadros, para que possam enfrentar as atribuições decorrentes da consolidação da área na esfera municipal, no caso de extinção do terreno de marinha, sem que 
a eliminação do referido instituto resulte na instituição de novo tributo, com a contrapartida de que a gestão da Orla Marítima seja feita de forma compatível com o conceito de patrimônio coletivo.

Enfim, caberá ao Poder Público Municipal elaborar e executar o Plano de Intervenção da Orla Marítima de modo participativo com o colegiado municipal, órgãos, instituições e organizações da sociedade interessados, lançando mão dos inúmeros instrumentos postos à sua disposição no Decreto n ${ }^{\circ}$ 5.300, de 07.12.2004 e na Lei nº 10.257, de 10.07.2001.

Portanto, a questão reside em conjugar os dois instrumentos de ordenamento do uso do solo à disposição das autoridades locais, o zoneamento costeiro e o zoneamento urbano decorrente do plano diretor do Município.

\section{c) Terreno de marinha}

Malgrado a necessidade de tratamento da zona costeira como uma totalidade geográfica, social e econômica e consequente disciplina jurídica unitária, o direito brasileiro persiste na manutenção do vetusto instituto do terreno de marinha, previsto no art. 20, da Constituição Federal e no art. $2^{\circ}$ do Decreto ${ }^{\circ}$ 9.760, de 05.09.1946, proporcionando uma sobreposição de competências (dominial da União com atividades dos Municípios) que constitui entrave ao desenvolvimento sustentável do ambiente costeiro urbano, 
A extinção do referido instituto, construído com base em critérios dotados de pouca cientificidade e estribado nos fundamentos de defesa nacional, instrumento condutor de política nacional de proteção ambiental e de planejamento urbano, constitui providência destinada a eliminar gargalo que dificulta o desenvolvimento das regiões costeiras, seja pela imposição de ônus despido de contrapartida, seja pelos entraves burocráticos causados pela referida sobreposição de competência.

Ademais, a precariedade dos critérios de delimitação da linha de costa constitui expressivo argumento em favor de um tratamento que abarque a totalidade da zona costeira e não apenas essa estreita faixa, e, ainda que se considere a correção científica de trabalhos recentes, isso não altera a desnecessidade da manutenção do instituto em testilha, mormente considerada a insegurança jurídica das consequências advindas da modificação dos critérios até então utilizados.

Referidos argumentos não subsistem diante da atual tecnologia de defesa, da superveniência da política urbana delineada no art. 182 da Constituição Federal, efetivada pela Lei n ${ }^{\circ} 10.257$, de 10.07.2001, e da previsão da participação do Município no Plano Nacional de Gerenciamento Costeiro.

Em abono a essa tese, os Projetos de Emenda Constitucional n ${ }^{\circ}$ 53/07 e 56/09 preveem sua extinção, consolidando o domínio dos terrenos de marinha na esfera particular sem implicar 
na transferência das receitas hauridas pela União ao Município e tampouco na criação de novos tributos. Destarte, sua manutenção justifica-se por intuito meramente arrecadatório.

\section{d) Exercício do poder de polícia pelo Município}

O uso e a ocupação do solo e as atividades realizadas em áreas urbanas ou urbanizáveis são sujeitas à disciplina e tributação municipais, cabendo a reserva dominial da União aos aspectos ligados à defesa nacional, bem como à disciplina geral da matéria.

Distingue-se aqui, a competência dominial da União pela titularidade dos terrenos de marinha da competência para disciplina de atividades localizadas na zona costeira, precipuamente do Município (exceção feita à navegação e instalações militares).

Nesta quadra, o diálogo enquanto instrumento consensual emerge como procedimento balizador, presente nos mecanismos de acordos regulatórios, atividade de fomento, audiência e consulta públicas, com permanente revisão das decisões, excercendo o poder público municipal papel de destaque porquanto constituir o locus decisório mais próximo da realidade local e, portanto, mais propenso à obtenção de soluções mais eficazes.

A existência de vias de acesso às praias e ao mar sob o domínio privado, ou a simples inexistência delas, constitui flagrante ilegalidade, como é ilegal qualquer óbice, impedimento ou dificuldade ao uso dessas vias de forma livre, ampla, geral e franca, exceção feita às áreas 
de interesse da segurança nacional ou protegidas por legislação específica, situada a questão no âmbito do exercício do poder de polícia municipal.

e) Alcance da locução interesse local

Ao Município compete legislar sobre assunto de interesse local, expressão utilizada pela Carta atual em substituição, sem alteração de conteúdo, à expressão 'peculiar interesse'.

A matéria objeto de legislação municipal sobre interesse local pode ser multiplicada ad infinitum, vez que seus contornos são os limites que o próprio entendimento da locução interesse local pressupõe, afastadas matérias estritamente ligadas à defesa nacional ou a bens de domínio e inquestionável interesse da União, como o mar territorial e a plataforma continental.

A concreção do referido interesse se efetivará caso a caso, pelo próprio Município na realização dos interesses políticos, financeiros e sociais decorrentes de sua capacidade de auto organização, autogoverno, auto administração e normatização, toda vez que a realização do interesse local estiver ameaçada ou comprometida, preponderando este sobre os demais entes federativos, exceção feita às hipóteses de omissão ou inépcia do Município, por força do princípio da subsisdiedariedade. 
Com a extinção dos terrenos de marinha, o exercício do interesse local pelo Município poderá se dar de forma ampla e desembaraçada, sem a constante e desnecessária interferência da União, sempre distante da intensa e dinâmica realidade local que o Município, melhor do que qualquer outro conhece.

f) Incremento da atividade turística

O progresso repentino experimentado pela indústria do turismo no Brasil, somado à inclusão de amplas parcelas da população nos setores médios, exigem investimentos em planejamento, saneamento básico, transporte, sistema viário, saúde, energia, telecomunicações, planejamento urbanístico, instalações náutico-desportivas, parques aquáticos, marinas, entre muitas outras providências somente possíveis pela percepção do poder público local, pelo manejo dos instrumentos previstos no art. $4^{\circ}$ da Lei $n^{\circ} 10.257$, de 10.07.2001, pela participação em programas específicos como o Projeto Orla e sua ação em parceria com o setor privado e a comunidade.

No entanto, o desenvolvimento da indústria do turismo costeiro não deve ter por preço a ser pago, o declínio da qualidade de vida e o comprometimento dos diversos ecossistemas que constituem a diversificada zona costeira nacional. Esse processo, em que o município desempenha papel de maior relevo, beneficiado ademais com a valorização imobiliária e consequente aumento de arrecadação, se bem gerenciado, só trará benefícios às populações diretamente envolvidas em um primeiro momento, mas, em médio prazo, a toda a economia nacional. 


\section{g) Impactos da extração de petróleo e gás}

As recentes descobertas de jazidas de gás e petróleo na camada do pré-sal, situada na Bacia de Santos, intensificarão as atividades industrial e de serviços e acentuarão o processo de urbanização, bem como agravarão os riscos ambientais ante a vultosa infraestrutura de operações e instalações de apoio logístico, exigidas pela atividade, tanto no mar como em terra, não se olvidando da especulação imobiliária decorrente do incremento da atividade.

Não obstante previsão constitucional assegurando à União a propriedade dos recursos minerais, petróleo e gás natural, os impactos da atividade econômica no meio urbano/ambiental local exigirão providências que irão onerar os Municípios, seja pelo atendimento de demandas sociais por moradia, emprego, transporte, saneamento e urbanização decorrente do inevitável aumento da malha urbana para acomodar o crescimento populacional, ou pelo exercício do poder de polícia fiscalizador, visando resguardar o interesse local, nem sempre compatível com o nacional.

A adequada utilização das receitas advindas da exploração do petróleo e gás pode ser assegurada pela criação de fundos, vinculação das rendas provenientes da atividade ou, ao menos, pela imposição de maiores restrições à utilização perdulária da CFEM - Compensação Financeira pela Exploração de Recursos Minerais pelos Municípios, propiciando atividades que substituirão ao extrativismo após o esgotamento das jazidas, pois o uso das rendas 
hauridas da exploração é o elemento crítico que pode fazer diferença entre uma atividade que se converte em dádivas ou, ao contrário, que produz maldição.

\section{h) Expansão do Sistema portuário}

Terminais portuários apresentam especial potencial de risco ambiental, seja pelo transporte via embarcações ou dutos, seja pelos processos de carregamento e descarregamento do produto. Apresentam ademais risco de acidentes que podem causar danos de expressiva extensão em seu entorno (explosões e incêndios), agravados se localizados no perímetro urbano, como muitos portos brasileiros. Acresça-se a isso, a deterioração do entorno urbano causada pela desativação dos terminais de passageiros ocorrida com o desenvolvimento do transporte aéreo.

Não obstante o fato de que toda a atividade econômica do país, convergir para os portos, contabilizando-se nessa atividade todo o sistema de transporte, energia e comunicações, enfim, a vida econômica e, por consequência, a vida social da nação, não há como afastar o interesse local no exercício e fiscalização de tais atividades, pois não apenas o bônus econômico e social com o seu desenvolvimento, mas também o ônus chama a comunidade local à participação. 


\section{REFERÊNCIAS BIBLIOGRÁFICAS}

AFONSO, José Roberto Rodrigues; GOBETTI, Sérgio Wulff. Rendas do petróleo no Brasil: Alguns aspectos fiscais e federativos. Revista do Banco Nacional de Desenvolvimento Econômico e Social, Rio de Janeiro, n. 30, p. 231-269, dez. 2008.

ALEXY, Robert. Teoria dos direitos fundamentais. 2 ed. 2 tiragem. Trad. Virgílio Afonso da Silva, São Paulo: Malheiros, 2011.

ALFONSEA, F. Torres. Ordenación del litoral en la Costa Blanca, Alicante. Alicante: Publicaciones de la Universidad de Alicante, 1997;

ALMEIDA, Fernanda Dias Menezes de. Competências na Constituição de 1988. 2. ed. São Formatado: Fonte: (Padrão) Times New Roman, 12 pt, Espanhol (Espanha - tradicional)

Formatado: Fonte: (Padrão) Times New Roman, 12 pt, Espanhol (Espanha - tradicional)

Formatado: Fonte: (Padrão) Times New Roman, 12 pt, Espanhol (Espanha - tradicional)

Paulo: Atlas, 2000.

ALMEIDA, Fernando Dias Menezes de. Crítica ao tratamento constitucional do Município como ente da Federação Brasileira. Revista de Direito Constitucional e Internacional. São Paulo: Revista dos Tribunais - Instituto Brasileiro de Direito Constitucional, p. 76-85, $\mathrm{n}^{\circ}$ 68, jul.-set. 2009, 
ARAGÃO, Alexandre Santos de. Atividades privadas regulamentadas: poder de polícia e regulação. Revista Forense, vol. 383, Rio de Janeiro, Forense, p. 03-04, jan.-fev. 2006.

Autorizações administrativas. Revista Tributária e de Finanças Públicas. Revista dos Tribunais, vol. 62, São Paulo, Revista dos Tribunais, p. 192-212, mai.-jun. 2005.

; MARQUES NETO, Floriano de Azevedo (Org.). Direito Administrativo e seus novos paradigmas. Belo Horizonte: Fórum, 2008.

ARAÚJO, Edmir Netto de. Curso de direito administrativo. $5^{\text {a }}$ ed. São Paulo: Saraiva, 2010.

BACELLAR SOBRINHO, Gilberto Huet. Decreto Presidencial regulamenta o uso e a ocupação da Zona Costeira e estabelece os critérios para a Gestão da Orla Marítima. Secretaria Estadual do Meio Ambiente do Estado do Rio de Janeiro. Revista Gestão Costeira Integrada para países de língua portuguesa, n. 5, ano 4, 2006. http//www.gci.inf.br

BANUNAS, Ioberto Tatsch. Poder de polícia ambiental e o município. Porto Alegre: Sulinas, 2003.

BARAGÁN MUÑOZ, Juan Manuel (Dir.). Guia de buenas praticas del litoral Gaditano. Universidad de Cádiz. Diputación de Cádiz: Servicio de Publicaciones, 2002. 
La gestión de áreas litorales en Espana y Latinoamérica. Universidad de Cádiz. Diputación de Cádiz: Servicio de Publicaciones, 2005.

. Medio ambiente y desarollo em áreas litorales. Introdución a la planificación y gestión integradas. Universidad de Cádiz, Servicio de Publicaciones de la UCA, 2003.

Ordenación, planificación y gestión del espacio litoral. Barcelona: Oikos - Tau, 1994.

BASTOS, Celso Seixas Ribeiro. O município: sua evolução histórica e suas atuais competências. Cadernos de Direito Constitucional e Ciência Política, São Paulo, Revista dos Tribunais - Instituto Brasileiro de Direito Constitucional, n. 1, p. 54-76, out.-dez. 1992.

MARTINS, Ives Gandra. Comentários à Constituição do Brasil. 2. ed. São Paulo: Saraiva, 2000.

BECKER, Bertha K. Levantamento e avaliação da política federal de turismo e seu impacto na região costeira. Brasília: Plano Nacional de Maio Ambiente, 1996. 
BELCHIOR, Constança de Carvalho. Gestão costeira integrada - Estudo de caso do Projeto ECOMANAGE na Região Estuarina de Santos-São Vicente. Dissertação de Mestrado Ciência Ambiental, Instituto Oceanográfico da Universidade de São Paulo, 2008.

BERCOVICI, Gilberto. Direito econômico do petróleo e dos recursos minerais. São Paulo: Quartier Latin, 2010.

CARCELLER FERNÁNDEZ, Antonio. Instituiciones de derecho urbanístico, 5. ed. Madrid: Montecorvo, 1992.

Introducción ao derecho urbanístico. 2. ed. Madrid: Tecnos, 1993.

CARDOZO, José Eduardo; SANTOS, Márcia Walquíria Batista; QUEIROZ, João Eduardo Lopes. Curso de Direito Administrativo Econômico, 2 vol. São Paulo: Malheiros, 2011.

CARNEIRO, Levi. Terras devolutas, Terrenos de marinha. Revista de Direito Administrativo, Rio de Janeiro, FGV, vol. 4, p. 353-371, abr. 1946.

CARVALHO, Vitor Celso de. A zona costeira brasileira - Subsídios para uma avaliação ambiental. Brasília: Ministério do Meio Ambiente e da Amazônia Legal, 1994. 
CARVAlHO FILHO, José dos Santos. Manual de Direito Administrativo. 25 ed. São Paulo: Atlas, 2012.

CASTILHO, José Roberto Fernandes. O plano local no direito urbanístico brasileiro e comparado. Tese de doutorado, Universidade de São Paulo, 1997.

CASTRO, José Nilo. Direito Municipal Positivo. Belo Horizonte: Del Rey, 2006.

CHAVES, Antônio. Praias, ilhas e terrenos de marinha. Revista Trimestral de Jurisprudência dos Estados, n. 109, São Paulo, Vellenich, p. 9-28, fev. 1993.

CLARK, J. R. Coastal zone management handbook. New York: Lewis Publishers, 1996.

CUNHA, Ícaro. Portos no ambiente costeiro. Santos: Universitária Leopoldianum, 2004.

; NEVES, Maria Fernanda Brito (Org.). Gestão ambiental na costa. Portos e sustentabilidade. 2 ed. Santos: Leopoldianum, 2009.

CUNHA, Sérgio Sérvulo da. Município: Poder de Polícia sobre a Zona Costeira. Revista dos Tribunais, n. 686, São Paulo, Revista dos Tribunais p. 269-273, dez. 1992. 
DALlARI, Adilson de Abreu; DI SARNO, Daniela Campos Libório (Org.). Direito urbanístico e ambiental. Belo Horizonte: Fórum, 2007.

; FERRAZ, Sergio (Coord.). Estatuto da cidade, São Paulo: Malheiros, 2002.

DANTAS, Marcelo Buzaglio; SEGUIN, Elida; ABMET, Flávio. O Direito Ambiental na atualidade: Estudos em homenagem a Guilherme José Purvin de Figueiredo. Rio de Janeiro: Lumen Juris, 2010.

DERANI, Cristiane. Direito ambiental econômico. 3. ed. São Paulo: Saraiva, 2008.

(Org.) . Direito ambiental internacional. Santos: Leopoldianum, 2011.

DI PIETRO, Maria Sylvia Zanella. Uso privativo de bem público por particular. 2 ed. São Paulo: Atlas, 2010.

DIAS, João Manoel Alveirinho; POLETE, Marcos. Gestão costeira integrada - FUMA Universidade de Algarve / UNIVALI - Universidade do Vale do Itajaí, no 5, 2006. www.gci.inf.br 
DIEGUES, Antonio Carlos Sant'Ana (Org.). Povos e águas: inventário de áreas úmidas. 2 ed. São Paulo: Núcleo de Apoio à Pesquisa sobre Populações Humanas e Áreas Úmidas Brasileiras, Universidade de São Paulo, 2002.

Valoração econômica-ambiental das zonas úmidas costeiras: análise da inter-relação entre a Convenção RAMSAR e a legislação brasileira de proteção da Zona Costeira. Revista de Direito Ambiental, n. 48, São Paulo, Revista dos Tribunais, p. 102-117, 2007.

DIEHL, Francelise Pantoja; XAVIER, Grazielle; BRANCHER, Nivia Daiane Régis. Proteção jurídica dos manguezais e estuários: uma abordagem a partir do Plano Nacional de Gerenciamento Costeiro e da Convenção de Ramsar. Revista de Direito Ambiental, n. 44. São Paulo: Revista dos Tribunais, p. 9-39, out.-dez. 2006.

; PEREIRA, Sharon de Rosa. Valoração econômico-ambiental das zonas úmidas costeiras: análise da inter-relação entre a Convenção Ramsar e a legislação brasileira de proteção da zona costeira. Revista de Direito Ambiental, n. 48. São Paulo: Revista dos Tribunais, p. 102-117, out.-dez. 2007.

DROBENKO, Bernard. Droit de l'urbanisme. 2 ed. Paris: Gualino, 2005. 
EGLER, Claudio A. Gonçalves. Os impactos da política industrial sobre a zona costeira. Brasília: Ministério do Meio Ambiente, 1997.

ELUSTIZA, Angel Sustaeta. Propriedad y urbanismo. Madrid, Montecorvo, 1978.

ENRÍQUEZ, Maria Amélia. Mineração: maldição ou dádiva. Os dilemas do desenvolvimento sustentável a partir de uma base mineira. São Paulo: Signus, 2008.

FARIAS, Talden. A repartição de competências para o licenciamento Ambiental e a atuação dos municípios. Revista de Direito Ambiental, n. 43, São Paulo, Revista dos Tribunais, p. 246-266, jul.-set. 2006.

FENSTERSEIFER, Tiago. Direitos fundamentais e proteção do ambiente. A dimensão ecológica da dignidade humana no marco jurídico-constitucional do estado socioambiental do direito. Porto Alegre: Livraria do Advogado, 2008. 
FERNANDEZ, Tomás-Ramon. Manual de derecho urbanistico. 13 ed. Madrid: Abella, 1998.

FERRARI, Regina Maria Macedo Nery, Competência legislativa do município. Cadernos de Direito Constitucional e Ciência Política, n. 1, São Paulo, Revista dos Tribunais - Instituto Brasileiro de Direito Constitucional, p. 258, out.-dez. 1992.

Direito municipal. 3 ed. São Paulo: Revista dos Tribunais, 2012.

FERRAZ JÚNIOR, Tércio Sampaio. Normas gerais e competência concorrente: uma exegese do art. 24 da Constituição Federal. Revista Trimestral de Direito Público, nº 7, São Paulo, Malheiros, p. 245-251, jul.-set. 1994.

FIGUEIREDO, Guilherme José Purvin de. A propriedade no direito ambiental. 3. ed. São Paulo: Revista dos Tribunais, 2008.

FIGUEIREDO, Lúcia Valle. Discriminação constitucional das competências ambientais. Revista de Direito Ambiental, n. 35, São Paulo, Revista dos Tribunais, p. 39-55, jul.-set. 2004. 
FREITAS, Jussara Shirazawa; NOVELLI, Yara Schaeffer. Políticas públicas como ferramenta do gerenciamento costeiro, Praia da Cocanha, Caraguatatuba. São Paulo. V Simpósio Brasileiro de Oceanografia. Santos, 2011.

GARCIA, Maria. Política urbana e a questão habitacional, Cadernos de Direito Constitucional e Ciência Política, n. 22, São Paulo, Revista dos Tribunais - Instituto Brasileiro de Direito Constitucional, p. 72-96, jan.-mar. 1998.

GASPARINI, Diógenes. Direito administrativo. 16. Ed. São Paulo: Saraiva, 2011.

GONÇALVES, Alcindo; RODRIGUES, Gilberto M. A. Direito do Petróleo e Gás: aspectos ambientais e internacionais. Santos: Universitária Leopoldianum, 2007.

GRANZIERA, Maria Luiza Machado. Direito ambiental. 2 ed. São Paulo: Atlas, 2011.

GRAU, Eros Roberto. Poder de polícia: função administrativa e princípio da legalidade. O chamado direito alternativo. Revista Trimestral de Direito Público, n. 1, São Paulo, Malheiros, p. 88-103, 1993.

INSTITUTO POLIS/PETROBRAS. Diagnóstico urbano socioambiental - Convênio Petrobras/Instituto Polis - Bases das informações até 2012 / Revisão março 2013. 
JAKOB, Alberto Augusto Eichman. Análise sócio-demográfica do espaço urbano da Região metropolitana da Baixada Santista no período de 1960-2000. Tese de Doutorado - Instituto de Filosofia Economia Humana - UNICAMP, 2003.

JUSTEN FILHO, Marçal Curso de direito administrativo, 9. ed., São Paulo: Revista dos Tribunais, 2013.

KELSEN, Hans. Teoria pura do direito. 6. ed. Coimbra: Armênio Amado, 1984.

KISHI, Sandra Akemi Shimada; SILVA, Solange Teles da; SOARES, Inês Virginia Prado (Org.). Desafios do direito ambiental no século XXI: estudos em homenagem a Paulo Affonso Leme Machado. São Paulo: Malheiros, 2005.

LEAL, Victor Nunes. Coronelismo, enxada e voto (O Município e o Regime Representativo no Brasil). Rio de Janeiro: Forense, 1948.

LEMOS, Amália Inês Geraides (Org.). Turismo: Impactos socioambientais. São Paulo: HUCITEC, 1996. 
LIMA, Obéde Pereira de; PHILIPS, Jurgen Wilhelm. Demarcação dos terrenos de marinha e seus acrescidos. Revista de Direito Imobiliário, n. 59, São Paulo, Revista dos Tribunais, p. 166-193, jul.-dez. 2005.

LÓPEZ, P. Rodriguez. Playas y costas en el derecho español. A propósito de La ley de costas de 1988. Barcelona: BOSCH, 2010.

MACHADO, Paulo Affonso Leme. Direito ambiental brasileiro. 21. ed. São Paulo: Malheiros, 2013.

O município e o direito ambiental. Revista Forense, n. 317, Rio de Janeiro, Forense, p. 189-194, jan.-mar. 1992 .

MALUF, Carlos Alberto Dabus. Limitações ao direito de propriedade. 3. ed. São Paulo: Revista dos Tribunais, 2011.

; MALUF, Adriana Caldas do Rego Freitas Dabus. Comentários ao Estatuto da Cidade. São Paulo: Atlas, 2010. 
MARQUES NETO, Floriano de Azevedo. A possibilidade de restrição de acesso a bens públicos de uso comum por questões ambientais e urbanísticas. Boletim de Direito Administrativo, n. 6, São Paulo, NDJ, p. 665-682, jun. 2007.

A servidão administrativa como mecanismo de fomento de empreendimentos de interesse público. Revista de Direito Administrativo, vol. 254, Rio de Janeiro, p. 109-136, mai.-ago. 2010.

O conflito entre princípios constitucionais: breves pautas para sua solução. Cadernos de Direito Constitucional e Ciência Política, vol. 10, São Paulo, Revista dos Tribunais/Instituto Brasileiro de Direito Constitucional, p. 40-45, jan.-mar. 1995.

O regime jurídico das utilidades públicas: função social e exploração econômica dos bens públicos. Tese de Livre-Docência, Universidade de São Paulo, 2008.

; LEITE, Fábio Barbalho. Peculiaridades do contrato de arrendamento portuário. Revista de Direito Administrativo, vol. 231, Rio de Janeiro, p. 269-295, jan.-mar. 2003.

MARTINS, Filomena Martins; ALBUQUERQUE, Henrique. M. Politicas de planeamento, ordenamento e gestão Costero. Contributo para uma discussão metodológica. Tese de 
Doutorado, Universidade de Aveiro - CESAM, Departamento de Ambiente e Ordenamento, 1998.

MARTINS JÚNIOR, Wallace Paiva. Praças e praias públicas. Justitia, n. 168, São Paulo, Procuradoria Geral de Justiça, p. 70-89, out-dez. 1994.

MATEO, Ramón Martin. Manual de derecho ambiental. Madrid: Trivium, 1995.

; REBOLLO, J. Fernando Vera. Problemas de ordenacion territorial y urbanistica en el litoral survalenciano: consideraciones sobre planeamiento, conservacion de costas y promocion del turismo residencial. Revista de Derecho Urbanístico,n. 114, Madrid, Montecorvo, p. 13-27 (631/648). jul.-sep. año XXIII.

MATTOS NETO, Antonio José. Competência legislativa municipal sobre meio ambiente. Revista de Direito Ambiental, n. 14, São Paulo, Revista dos Tribunais, p. 120-133, abr.-jun. 1999.

MEDAUAR, Odete. A força vinculante das diretrizes da Política Urbana. Revista Jurídica da Procuradoria Geral do Município de São Paulo, n. 6, São Paulo: CEJUR, p. 51-59, mar. 2008. 
A processualidade no direito administrativo. 2 ed., São Paulo: Revista dos Tribunais, 2008.

Controle da Administração Pública. 2 ed., São Paulo: Revista dos Tribunais, 2012.

Convênios e consórcios administrativos. Revista Jurídica da Procuradoria Geral do Município de São Paulo, n. 2, São Paulo: CEJUR, p. 69-89, 1996.

Delegação administrativa. Revista Forense, n. 278, Rio de Janeiro, Forense, p. 21-27, abr.-jun. 1982.

. Direito Administrativo Moderno. 16. ed. São Paulo: Revista dos Tribunais, 2012.

O direito administrativo em evolução, 2. ed. São Paulo: Revista dos Tribunais, 2003.

; ALMEIDA, Fernando Dias Menezes de (Coord.) Estatuto da Cidade: Lei $n$. 10.257/2001. São Paulo: Revista dos Tribunais, 2004.

; SCHIRATO, Victor Rhein (Org.) Atuais rumos do processo administrativo. São

Paulo; Revista dos Tribunais, 2010. 
; SCHIRATO, Vitor Rhein. (Coord.). Os caminhos do ato administrativo. São Paulo:

Revista dos Tribunais, 2011.

; SILVA, Solange Teles; MARQUES, Claudia Lima. O novo direito administrativo, ambiental e urbanístico - Estudos em homenagem a Jacqueline Morand-Deviller. São Paulo: Revista dos Tribunais, 2010.

MEIRELLES, Hely Lopes, Direito administrativo brasileiro. 38. ed. São Paulo: Malheiros, 2012.

Direito municipal brasileiro. 16. ed. São Paulo: Malheiros, 2008.

MELLO, Diogo Lordello de. O fenômeno urbano no Brasil, in. O Município e o Direito urbano, IBAM - 1974. Texto baseado em notas taquigráficas da conferência pronunciada em 07.05.1973, ao instalar no auditório do IBAM o Seminário sobre Direito Urbano.

MINISTÉRIO DO MEIO AMBIENTE. Guia de Implementação do Projeto Orla. Ministério do Meio Ambiente / Secretaria de Qualidade Ambiental nos Assentamentos Humanos, Ministério do Planejamento, Orçamento e Gestão / Secretaria do Patrimônio da União. 2005. http://www.mma.gov.br/projetoorla. 
—. Agenda 21 - Conferência das Nações Unidaes sobre Meio Ambiente e Desenvolvimento. 3 ed. Brasília: Senado Federal - Subsecretaria de Edições Técnicas, 2001. . Macrodiagnóstico da zona costeira do Brasil na Escala da União. Brasília: 1996.

Secretaria de Extrativismo e Desenvolvimento Rural Sustentável. Departamento de Zoneamento Territorial. Gerência Costeira - Relatório de Gestão / Gerência Costeira 20112012. Brasília, 2013.

MORAES, Antonio Carlos Roberto. Contribuições para a gestão da zona costeira do Brasil Elementos para uma geografia do litoral brasileiro. São Paulo: Annablume - HUCITEC EDUSP, 2007.

MORAND-DEVILLER, Jacqueline. Cours de droit administratif, 12 ed. Paris: Montchrestien, 2011.

Cours de droit administrartif des biens. 3 ed. Paris: Montchrestien, 2003.

Droit de l'urbanisme. 3. ed. Paris: Dalloz, 1996. 
. L'environnement et le droit. Paris: LGDJ, 2001.

MOREIRA NETO, Diogo Figueiredo. Competência concorrente limitada: o problema da conceituação das normas gerais. Revista de Informação Legislativa, vol. 25, n. 100, Brasília, p. 127-162, out.-dez. 1988.

NOGUEIRA, J. C. Ataliba. O município e os munícipes na Constituição de 1946. São Paulo: Departamento Estadual de Informações, 1947.

NUSDEO, Ana Maria de O. Defesa da concorrência e globalização econômica: o controle da concentração de empresas. São Paulo: Malheiros, 2002.

Desenvolvimento sustentável no Brasil e o Protocolo de Quioto. Revista de Direito Ambiental, n. 37, São Paulo, Revista dos Tribunais, p. 144-159, jan.-mar. 2005.

OLIVEIRA, Régis Fernandes de. Comentários ao Estatuto da Cidade. 2 ed. São Paulo: Revista dos Tribunais, 2005.

; PEREIRA, José Horácio Cintra Gonçalves; LOBO JR, Hélio. A competência do município na disciplina urbanística. Revista de direito imobiliário, n. 9, São Paulo, Revista dos Tribunais, p-18-23, jan.-jun.1982. 
PASSOS DE FREITAS, Mariana Almeida. Zona costeira e meio ambiente. Curitiba: Juruá, 2005.

PASSOS DE FREITAS, Vladimir. (Coord.) Águas, aspectos jurídicos e ambientais. 3. ed. Curitiba: Juruá, 2007.

Direito Administrativo e Meio Ambiente. 4. ed. Curitiba: Juruá, 2010.

PINTO, Victor Carvalho. Direito urbanístico. 2. ed. São Paulo: Revista dos Tribunais, 2010.

PRESTES, Vanesca Buzelato. A necessidade de compatibilização das licenças ambiental e urbanística no processo de municipalização do licenciamento ambiental. Revista de Direito Ambiental, São Paulo, Revista dos Tribunais, vol. 34, p. 84-96, abr.-jun. 2004.

Instrumentos legais e normativos de competência municipal em matéria ambiental. Revista de Direito Ambiental, n. 31, São Paulo, Revista dos Tribunais, p. 100-116, jul.-set. 2003. 
RAYMUNDO E SILVA, José Alfredo. Terrenos de marinha, seus acrescidos e a administração municipal. Revista de Direito Público, n. 37/38, São Paulo, Revista dos Tribunais, p. 316-326, jan.-jun. 1976.

REALE, Miguel. Lições Preliminares de Direito. 27. ed. São Paulo: Saraiva, 2002.

REIXACH, Ángel Menédez. El rol de los poderes locales u regionales. Impactos urbanísticos en el litoral onubense: el dilema entre conservación y desarollo. Huelva, 1989.

La nueva ley de costas: el dominio público como régimen jurídico de especial proteción, ordenación y desarollo del turismo en Espana y Francia. Palma de Majorca, 1991.

RODRIGUES, Adyr Balastreri (org.). Turismo e ambiente - reflexões e propostas. 2. ed. São Paulo: Ed. Hucitec, 2000.

RODRIGUES, Marcelo Abelha. Instituições de direito ambiental. São Paulo: Max Limonad, 2002.

ROMANI, Carlos Fernandez de Casadevante. La protection del medio ambiente en derecho internacional, derecho comunitario europeo y derecho español. Vitoria-Gasteiz: Servicio Central de Publicaciones del Gobierno Vasco, 1991. 
ROMI, Raphael. Domat - Droit Public. Droit et administration de l'environnement. 2 ed. Paris: Montchrestien, 1997.

ROSS , Alf. Direito e Justiça. Trad. Edson Bini. São Paulo: Edipro, 2003.

RUFINO, Gilberto D’Ávila. A condição jurídica dos aterros das praias do mar. Revista de Direito Público, n. 97, São Paulo, Revista dos Tribunais, p. 243-252, jan.-mar, 1991.

Regime legal das marinas no direito comparado. Revista de Direito Ambiental, n. 24, São Paulo, Revista dos Tribunais, p. 102-116, out.-dez. 2001.

RUSCHMANN, Doris. Turismo e planejamento sustentável: a proteção do meio ambiente. São Paulo: Papirus editora, 1997.

SACHS, Ignacy. Desenvolvimento includente, sustentável, sustentado. Rio de Janeiro: Garamond, 2004.

SCAFF, Fernando Facury ; ATHIAS, Jorge Alex (Coord.). Direito Tributário e Econômico aplicado ao meio ambiente e à Mineração. São Paulo: Quartier Latin, 2009. 
SCHERER, Marinez. Bandeira Azul: Um programa de certificação ambiental de praias contribuindo para a política brasileira de gerenciamento costeiro. In Gestão Costeira Integrada, Secretaria Estadual do Meio Ambiente do Estado do Rio de Janeiro. Revista Gestão Costeira Integrada para países de língua portuguesa, n. 5, ano 4, 2006. http//www.gci.inf.br

SCHIRATO, Vitor Rhein. A ressurreição da desapropriação para fins urbanísticos. Boletim de Direito Administrativo, vol. 8, São Paulo, NDJ, p. 976-990, ago. 2012.

Transportes aquáticos. Doutrina, jurisprudência, legislação e regulação setorial. São Paulo: Saraiva, 2012.

SECRETARIA DO ESTADO DO MEIO AMBIENTE. Zoneamento Ecológico-Econômico do Litoral Norte. Coordenadoria de Planejamento Ambiental Estratégia e Educação Ambiental. São Paulo: SMA/CPLEA, 2005.

SERAFINI, Leonardo Zagonel. O zoneamento costeiro e as competências municipais: uma análise à luz da legislação ambiental brasileira. Revista de Direitos Difusos, n. 30 - Teses de Foz do Iguaçu II, Rio de Janeiro, ADCOAS, p. 07-27, mar.-abr. 2005. 
SILVA, José Afonso. Direito Ambiental Constitucional. 9. ed. São Paulo: Malheiros, 2011;

Direito Urbanístico Brasileiro. 6. ed. São Paulo: Malheiros, 2010.

SILVA, Virgílio Afonso da. Direitos fundamentais. Conteúdo essencial, restrição e eficácia. 2 ed. 2 tiragem. São Paulo; Malheiros, 2011.

O conteúdo essencial dos direitos fundamentais e a eficácia das normas constitucionais. Tese Titularidade da Faculdade de Direito da Universidade de São Paulo, 2005.

SILVA, Solange Teles da. Planejamento urbano na Zona Costeira. In: Anais do XIV Congresso Nacional do Conselho nacional de Pesquisa e Pós-Graduação em Direito CONPEDI - Fortaleza (03, 04 e 05.11.2005).

SOARES, Carlos Roberto; ÂNGULO, Rodolfo José. Sobre a delimitação da linha preamar médio de 1831, que define os terrenos de marinha: DL 9.760/46. Revista de Direito Ambiental, n. 20, São Paulo, Revista dos Tribunais, p. 261-267, out.-dez. 2000.

SOARES JUNIOR, Jarbas e MIRANDA, Marcos Paulo de Souza, e PITOMBEIRA, Sheila Cavalcante (Coord.) Efetividade da tutela ambiental. Belo Horizonte: Del Rey, 2008. 
SUNDFELD, Carlos Ari. Direito administrativo ordenador. São Paulo: Malheiros, 2003.

TÁCITO, Caio. O poder de polícia e seus limites. Revista Forense, n. 144, Rio de Janeiro, Forense, p. 23-28, nov.-dez. 1952.

Princípio da legalidade e poder de polícia. Revista de Direito Administrativo, vol. 5, $\mathrm{n}^{\mathrm{o}} 10$, Rio de Janeiro, p. 15-25, jul.-dez. 2001,

Terrenos de marinha - Praia - defesa da fauna . Revista de Direito Administrativo, $\mathrm{n}$. 162, Rio de Janeiro, FGV, p. 311-316, out.-dez. 1985.

TORRES ALFONSEA, Francisco José. Ordenación del litoral en la Costa Blanca, Alicante: Publicaciones de la Universidad de Alicante, 1997.

TRAPERO, Juan Jesús. Aspectos urbanísticos de la proteción del territorio litoral. Revista de Derecho Urbanístico, n. 117, Madrid, Montecorvo, p. 53-64, mar.-abr. 1990. Año XXIV;

VÁZQUEZ, J. Barnes. Distribuición de competências em matéria de urbanismo. Barcelona: BOSCH, 2002. 
VERNBERG, F, J; VERNBERG, W. B. The coastal zone, past, present and future. University of South Carolina Press, 2001.

XAVIER, Márcio Morrone. O desenvolvimento histórico da autonomia municipal no Constitucionalismo brasileiro: concentração e desconcentração do poder no Brasil. Revista Assojuris, n. 112, Porto Alegre, ASSOJURIS, p. 205-225, set. 2008.

VITTA, Heraldo Garcia. Da divisão de competências das pessoas políticas e meio ambiente. Revista de Direito Ambiental, n. 10, São Paulo: Revista dos Tribunais, p. 93-101, abr.-jun. 1998.

Poder de polícia. São Paulo: Malheiros, 2010. 